\title{
Comunicação do resultado do teste HIV positivo no contexto do aconselhamento sorológico: a versão do cliente
}

Diva Maria Faleiros Camargo Moreno

Tese apresentada ao Programa de PósGraduação em Saúde Pública da Faculdade de Saúde Pública da Universidade de São Paulo para obtenção do título de Doutor em Saúde Pública.

Área de Concentração: Saúde Materno-Infantil Orientador: Prof. Dr. Alberto Olavo Advíncula Reis

São Paulo

2006 
É expressamente proibida a comercialização deste documento, tanto na sua forma impressa como eletrônica. Sua reprodução total ou parcial é permitida exclusivamente para fins acadêmicos e científicos, desde que na reprodução figure a identificação do autor, título, instituição e ano da tese. 


\section{DEDICATÓRIA}

A

Sílvio, Milton, Nei, Luis, Jonas, Juvenal, Arnaldo, Evandro, Cássio, Pedro, Mário, Omar, Paulo e Bruno

Pela disponibilidade em me contar suas histórias sobre um momento tão delicado de suas vidas

Às aconselhadoras

presentes na revelação desses resultados 


\section{AGRADECIMENTOS}

Ao finalizar esta tese, olho para trás e tento me lembrar do caminho percorrido e dos que nele me acompanharam. Foram muitas as pessoas que colaboraram comigo, ainda que não diretamente. A todas, o meu agradecimento, esperando poder lhes retribuir um dia. Tentarei nomeá-las, arriscando-me a esquecer de algumas:

-meus pais, Joaquim (in memoriam) e Zenaide, pelo oferecimento de um ambiente familiar afetivo e saudável no qual pude desenvolver o espírito da solidariedade tão necessário ao trabalho com a dor humana;

-Moreno, meu marido, por me acompanhar nestes anos todos desde a graduação, apoiando, discutindo idéias e providenciando as tecnologias necessárias;

-minhas queridas filhas Paula, Ana Carolina e Renata, pela disponibilidade para me ajudar em todas as fases desta tese: na transcrição de fitas, na revisão do texto, na execução do abstract e, finalmente, na revisão da formatação, mesmo afirmando que não gostavam da vida acadêmica. Espero que o trabalho as tenha transformado um pouco;

-Leandro, meu jovem colega de francês, por se revelar um excelente revisor e comentador do trabalho;

-meu irmão, irmãs, cunhados, cunhadas e sobrinhos, por serem meus grandes amigos e incentivadores com suas discussões estimulantes;

-Dra. Albina, minha chefe na época da coleta de dados, por permitir que minhas idas ao campo fossem consideradas como trabalho da unidade de saúde;

-Isabella e Vânia, amigas e colegas de trabalho, por sempre me apoiarem nas horas difíceis, incentivando-me a transpor os obstáculos, quase que diariamente;

-colegas do Laboratório de Saúde Mental Coletiva (LASAMEC), por opinarem sobre o trabalho na fase de pré-banca e, em especial, Alina, que se revelou amiga e colaboradora, dedicando seu tempo às minhas demandas, fazendo uma leitura crítica das entrevistas e providenciando a bibliografia necessária; 
-colegas do Núcleo de Estudos e Pesquisas para Prevenção da Aids (NEPAIDS), pelos seminários sempre muito instrutivos, e pela troca de informações ágil e profícua no espaço virtual;

-Kátia Bassichetto, por enviar, gentil e cordialmente, dados necessários ao estudo;

-Prof ${ }^{\mathrm{a}}$. Dr ${ }^{\mathrm{a}}$. Vera Paiva, pela presteza e disponibilidade para enviar os artigos e informações que requisitei de tempos em tempos;

-Prof. Dr. Ivan França Junior, pelas conversas informais no corredor do Departamento de Saúde Materno-Infantil e pelas suas idéias e contribuições que me ajudaram a pensar sobre certas indagações;

-Sonia Maria Berbare A. Parente, colega de graduação, por me emprestar um pouco do seu saber winnicottiano e por suas opiniões que me proporcionaram muita reflexão;

-equipes de aconselhadoras e funcionários dos CTA envolvidos, pela permissão de minha entrada no seu ambiente de trabalho e pela indicação dos voluntários para a pesquisa, que não seria possível sem a ajuda de todos eles;

-Solange e Cecília, respectivas chefes dos dois CTA, por se mostrarem sempre interessadas e prestativas, atendendo às minhas solicitações em todas as etapas do trabalho;

-Prof. Dr. Maurício Gomes Pereira, da Universidade de Brasília, que, mesmo sem me conhecer, enviou-me, gentil e rapidamente, a referência bibliográfica que eu necessitava;

-Dr. José Outeiral, por se dispor a me receber e a dialogar comigo, e também por ajudar a sustentar minha hipótese teórica, sugerindo leituras e dando suporte para o prosseguimento em uma etapa crítica deste estudo;

-professores e funcionários do Departamento de Saúde Materno-Infantil, pela acolhida carinhosa, simpática e estimulante desde os primeiros tempos; 
-Faculdade de Saúde Pública, representada pelos seus bons professores e funcionários educados e gentis, por possibilitar o desenvolvimento de um trabalho como este;

-Profa. Drª . Márcia Faria Westphal e Profa. Drª Rosana Onocko, por aceitarem gentilmente participar da Banca Examinadora;

-Prof ${ }^{\mathrm{a}}$. Dr ${ }^{\mathrm{a}}$. Maria Inês Assumpção Fernandes e Prof ${ }^{\mathrm{a}}$. Dr ${ }^{\mathrm{a}}$. Wilza Vieira Villela, pela atenção e confiança em mim depositadas e por aceitarem participar da banca examinadora desta tese desde a Defesa do Projeto e a Pré-banca, apresentando valiosas sugestões;

-Prof. Dr. José Ricardo Carvalho Mesquita Ayres e Profa. Dra . Fabíola Zioni, pelas muitas contribuições dadas na Pré-banca e por acreditarem neste trabalho; e

-Prof. Dr. Alberto Olavo Advíncula Reis, meu orientador, por aceitar a minha proposta de trabalho e por se dispor a pensar comigo em temas do meu interesse, dandome liberdade para criar. 


\section{RESUMO}

Moreno DMFC. Comunicação do resultado HIV positivo no contexto do aconselhamento sorológico: a versão do cliente [Tese de doutorado]. São Paulo: Faculdade de Saúde Pública da USP; 2006.

Introdução - O aconselhamento é a estratégia escolhida pela Organização Mundial da Saúde para o combate à epidemia de aids por ser um método de ajuda, apoio e prevenção. Objetivo - Analisar as características das interações aconselhador-cliente no processo da revelação do diagnóstico positivo para HIV em dois Centros de Testagem e Aconselhamento em DST e Aids do Município de São Paulo, com base na versão dos clientes e tomando por referência suas repercussões sobre os procedimentos e resultados da atividade. Métodos - Como técnica de coleta para o levantamento de dados, foi utilizada a entrevista em momento posterior ao aconselhamento pós-teste. No total, foram realizadas 20 entrevistas, sendo 14 os sujeitos de pesquisa. Todos os entrevistados eram do sexo masculino. Os critérios escolhidos para inclusão no estudo foram: ter 18 anos ou mais; ter resultado positivo no teste anti-HIV; e ter participado do processo de revelação do diagnóstico de infecção pelo HIV nos serviços pesquisados. Para organizar os dados, a autora utilizou a técnica de análise de conteúdo por entrevista e por tema, construindo categorias analíticas segundo os objetivos do estudo. Os dados foram analisados e interpretados por meio da utilização de conceitos da teoria psicanalítica de D.W.Winnicott. Resultados - Com base nos relatos, considera-se que os profissionais seguem bem o protocolo do aconselhamento, atingindo seus objetivos de: a) lidar com os sentimentos provocados pelo diagnóstico positivo para o HIV; b) dar ao cliente a oportunidade de expressar seu sofrimento e angústia; c) sustentar as dificuldades de compartilhar a notícia com familiares e parceiros; e d) tirar dúvidas sobre prevenção de DST/HIV e sobre a terapia antiretroviral. Os contextos de aconselhamento investigados caracterizaram-se pelas interações de ajuda e suporte para a maioria dos entrevistados, funcionando como realidade compartilhada e dando sustentação para seus sentimentos e preocupações. Entretanto, alguns clientes sentiram falta de espaço para discussão e de mais tempo para abordarem questões pessoais, além daquelas relacionadas à sua nova 
condição de portadores do HIV. Conclusões - Na versão dos clientes, os aconselhadores os acolhem, informam e apóiam em suas necessidades. A análise revelou os processos psicológicos que operaram no momento do aconselhamento pós-teste entre o sujeito de pesquisa e o aconselhador. A escuta do cliente é a condição primordial para que o ambiente de compartilhamento se instale. O estudo fornece subsídios para melhorar a qualidade deste serviço prestado à população.

Descritores: Aconselhamento, Teoria Psicanalítica de D.W.Winnicott, Comunicação do Resultado do Teste anti-HIV, Revelação do Diagnóstico de Soropositividade, Sorodiagnóstico da Aids. 


\begin{abstract}
Moreno DMFC. Comunicação do resultado HIV positivo no contexto do aconselhamento sorológico: a versão do cliente./Communicating the HIV positive result within the counseling process: the subject's version [Thesis]. São Paulo (BR): Faculdade de Saúde Pública da Universidade de São Paulo; 2006.
\end{abstract}

Introduction - Counseling is the strategy chosen by the World Health Organization against the aids epidemic since it is a method for help, support and prevention. Objective - To analyze the characteristics of counselor-subject interactions within the process of disclosing the positive diagnosis for HIV in two STD and Aids Counseling and Testing Centers in the city of São Paulo, according to the subjects' version and based on their repercussions of the activity's procedures and results. Methods - The technique used to gather data was the interview, performed after the counseling moment when test result was communicated. In total, 20 interviews were carried with 14 research subjects. All interviewed were men. The criteria chosen to include a subject in the research were: greater than 18 years of age; positive for HIV; and having received the positive diagnosis for HIV at the researched CTC. In order to organize the data, the author used the technique of analysis of content by interview and by theme, elaborating analytical categories based on the study objectives. The data was interpreted using the concepts of the psychoanalytical theory of D. W. Winnicott. Results - Based on the subjects' reports, it is considered that professionals follow the protocol for counseling, reaching its objectives, which are: a) dealing with feelings caused by the diagnosis; b) providing the opportunity to the subjects to express their suffering and anxiety; c) surpassing difficulties sharing the diagnosis with their family and partners; and d) clarifying questions about STD/HIV prevention and therapy. In the investigated counseling the interactions were characterized by the support and assistance for most of the subjects, acting as a shared reality and providing support to their feelings and concerns. However, some subjects felt the need for more time to discuss their feelings and personal issues, besides the ones related to their new HIV carrier condition. Conclusions - In the subjects' version, the counselors welcome them, provide 
information and support for their needs. The study revealed the psychological processes occurred during the post-test counseling between the subject and the counselor. Listening to the subject is the primary condition to establish a sharing environment. The study provides data to improve the service currently available to the population.

Descriptors: Counseling, Psychoanalytical Theory from D. W. Winnicott, Communicating the HIV Positive Result, Disclosing the Seropositive Diagnosis, AIDS Serodiagnosis. 


\section{ÍNDICE}

1. INTRODUÇÃO 13

1.1. REVISÃO DA LITERATURA 20

1.1.1. Sobre a Testagem e o Aconselhamento Sorológico 22

1.1.2. Sobre a Comunicação da Sorologia Anti-HIV Positiva 29

1.2. ASPECTOS CONCEITUAIS DO ACONSELHAMENTO 34

1.2.1. O Aconselhamento em DST, HIV e Aids 38

1.3. ENFOQUE TEÓRICO SOBRE O ESPAÇO PÚBLICO 43 INSTITUCIONAL

1.4. APORTE DA TEORIA DE D.W.WINNICOTT 48

1.5. JUSTIFICATIVA 57

2. OBJETIVOS 60

2.1. OBJETIVO GERAL 60

2.2. OBJETIVOS ESPECÍFICOS 60

3. MÉTODO 61

3.1. COLETA DE DADOS 61

3.1.1. Acerca do Trabalho de Campo 61

3.1.2. O Encontro com os Voluntários - As Entrevistas 64

3.1.3. Descrição dos Serviços e da População de Estudo 67

3.1.4. Considerações Éticas 70

3.2. ANÁLISE DAS ENTREVISTAS 71

4. RESULTADOS 74

4.1. APRESENTAÇÃO DOS SUJEITOS DE PESQUISA 74

4.2. ANÁLISE DE CONTEÚDO DE ACORDO COM OS 80 OBJETIVOS DA PESQUISA

4.2.1. Lugar Ocupado pelo Cliente em Relação à Escuta de suas 83

Preocupações e Sentimentos Decorrentes da Comunicação do

Resultado Positivo para o HIV

4.2.2. Enfoque Sobre as Práticas de Educação em Saúde Referentes 106 à Prevenção das DST/Aids, à Adesão à TARV e ao Autocuidado 
4.2.3. Aspectos Privilegiados na Comunicação do Resultado

Positivo

4.2.3.1. O Preenchimento da Ficha Epidemiológica

123

4.2.3.2. O Oferecimento de Outro Horário de Atendimento 124

4.2.3.3. A Superação das Dificuldades em Compartilhar a Notícia a

126 Outrem

4.3. PSICANÁLISE DO PROCESSO DE ACONSELHAMENTO

134

4.3.1. Como se Processou o Aconselhamento de Sílvio e Milton;

136

Nei, Luís e Juvenal; Evandro e Arnaldo; Mário e Pedro; Cássio;

Bruno e Jonas

4.3.2. Como se Processou o Aconselhamento de Omar e Paulo

158

5. CONSIDERAÇÕES FINAIS

173

6. REFERÊNCIAS BIBLIOGRÁFICAS

182

\section{ANEXOS}

Anexo 1. Unidades de DST/Aids, segundo macro regiões. Município

194 de São Paulo

Anexo 2. Termo de consentimento livre e esclarecido 195

Anexo 3. Formulário de atendimento dos CTA 196

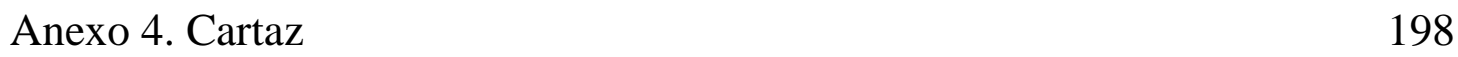

Anexo 5. Cartão-convite 199

Anexo 6. Tópicos abordados nas entrevistas 200 


\section{INTRODUÇÃO}

O presente estudo começou a ser pensado a partir da experiência de trabalho em prevenção do HIV em um Centro de Testagem e Aconselhamento em DST e Aids (CTA) da Secretaria Municipal da Saúde de São Paulo (SMS-SP). Como o próprio nome diz, esses serviços têm como principais atividades o aconselhamento (pré e pós-teste) e a testagem sorológica do HIV, da sífilis e, mais recentemente, da hepatite, visando o aumento do diagnóstico dessas doenças na população.

A Organização Mundial de Saúde (OMS) escolheu e recomenda, desde 1987, o aconselhamento como o método de ajuda, apoio e prevenção mais apropriado em âmbito mundial para enfrentar as ameaças individuais, comunitárias e coletivas engendradas pela epidemia da infecção pelo HIV (COUNSELING, SANTÉ ET DÉVELOPPEMENT 2002). Em 1988, a OMS constituiu um grupo de trabalho em Copenhague cujo produto foi um conjunto de recomendações aos países membros, dentre as quais: a criação de serviços de aconselhamento e apoio psicológico (WHO 1989). Esse documento era bastante focado nas pessoas infectadas e suas famílias, principais afetados pela epidemia naquele momento. $\mathrm{O}$ aconselhamento foi, então, a estratégia escolhida, e considerada fundamental no combate à epidemia, por congregar em seu desenvolvimento e prática as funções de informação, educação e comunicação, essenciais no trabalho preventivo (OMS 1991).

O Brasil aderiu a essa luta começando a organizar os serviços no âmbito e na criação dos programas de prevenção de DST/Aids. O Programa Nacional foi criado em 1988, mas no ano anterior já havia sido constituída a Comissão Nacional de Aids. O primeiro projeto de criação de um programa foi lançado no Estado de São Paulo em 1983, havendo, em 1986, a constituição de um grupo de trabalho formado por especialistas em caráter permanente. A Secretaria Municipal da Saúde de São Paulo criou o Programa de DST/Aids em 1987 (MORENO 2001).

A resposta brasileira à epidemia de aids é reconhecida atualmente como bem sucedida, tanto pela estabilização da curva de novas infecções como pela distribuição universal gratuita de medicamentos e pelas estratégias de prevenção inseridas em diferentes contextos. O sucesso foi resultado da luta pela liberdade democrática, do compartilhamento entre profissionais de saúde e ativistas pela defesa dos direitos 
humanos, da conquista da saúde pública gratuita e universal, e do compromisso com a emancipação e construção da cidadania (PAIVA 2002).

Os CTA foram criados na década 80, sob a denominação de Centro de Apoio e Aconselhamento Sorológico (COAS), para que as pessoas com dúvidas relacionadas ao seu estado sorológico quanto ao HIV, ou que se expuseram a situações de risco de infecção, pudessem realizar o teste anti-HIV. Apesar dos grandes avanços científicos acerca da importância do diagnóstico, tratamento e prevenção do HIV, a decisão de fazer ou não o teste ainda mostra-se difícil para os indivíduos, em função das conseqüências psicológicas, sociais e éticas que o resultado traz a eles. O preconceito e a discriminação que ainda existem em nossa sociedade em relação aos portadores do HIV afastam muitas pessoas da possibilidade e dos benefícios de um diagnóstico precoce da infecção, além de, em muitos casos, contribuir para a manutenção da cadeia de transmissão do vírus (MINISTÉRIO DA SAÚDE 2003).

Em função das dificuldades inerentes à decisão de submeter-se ao teste, é importante que a situação de exame seja acompanhada por profissionais especializados. Esses profisssionais são capacitados para oferecer aconselhamento pré e pós-teste adequado às pessoas, auxiliando-as na interpretação dos resultados e nas implicações dos mesmos em relação às suas próprias vidas e às de seus parceiros sexuais. Os profissionais fornecem, ainda, informação sobre as alternativas terapêuticas existentes face à possível confirmação do resultado positivo para o HIV.

Dentre os objetivos dos CTA, pode-se destacar: (i) o aumento do acesso ao diagnóstico da infecção pelo HIV, (ii) a diminuição dos riscos de transmissão do HIV e da re-infecção, (iii) o estímulo à adoção de práticas seguras de prevenção das DST/HIV e do uso indevido de drogas, (iv) o estabelecimento de referência para as pessoas soropositivas em relação aos serviços especializados, (v) a absorção da demanda que procura os bancos de sangue com o fim de conhecer a condição sorológica, (vi) o estímulo a realizar também o diagnóstico dos parceiros sexuais, e (vii) o auxílio aos ambulatórios de pré-natal na avaliação sorológica das gestantes. Além desses objetivos, os CTA promovem o desenvolvimento de trabalhos externos de prevenção para grupos populacionais específicos (MINISTÉRIO DA SAÚDE 
1999a, 1999b).

De acordo com a proposta da Área Técnica de DST/Aids do Município de São Paulo, ao realizar esses trabalhos externos os CTA respeitam as diferentes características regionais, havendo projetos específicos abordando populações consideradas mais vulneráveis, como profissionais do sexo, homens que fazem sexo com homens (HSH), adolescentes em situação de exclusão social, usuários de droga injetável e travestis, para os quais se criaram projetos direcionados (MESQUITA 2003). São ainda realizados os CTA Itinerantes, que têm por objetivo fazer chegar o teste anti-HIV às populações mais marginalizadas e com dificuldade de acesso aos serviços. Como exemplos desse trabalho podem ser citados o aconselhamento e testagem realizados com moradores de rua, com população encarcerada em delegacias, e em associações filantrópicas que atendem à população carente.

Diante dessas iniciativas, pode-se evidenciar que o oferecimento do teste antiHIV para a população é uma importante medida de saúde pública. O teste traz benefícios para a sociedade na medida em que possibilita o contato com as questões relativas ao HIV, aumentando o conhecimento sobre ele e promovendo a sensibilização das pessoas e a luta contra a estigmatização apoiando-se nos direitos humanos. A testagem visa: a prevenção da transmissão do HIV das pessoas soropositivas para seus parceiros não testados ou soronegativos e das mães soropositivas para seus bebês; o acesso mais imediato ao tratamento ou monitoramento, no caso de sorologias positivas; uma maior adesão ao tratamento de infecções relacionadas ao HIV e de outras DST; a orientação quanto ao planejamento familiar e a escolha baseada nos direitos reprodutivos; o apoio emocional aos soropositivos, seus parceiros e familiares; o suporte social e jurídico; e a melhora da capacidade de adaptação e de planejamento do futuro (ONUSIDA 2002).

MEURSING e SIBINDI (2000), em estudo qualitativo realizado no Zimbábue, descrevem as necessidades e os problemas emocionais, sociais e informativos de pacientes soropositivos recém-diagnosticados. Eles observaram que, apesar de muitos possuírem informação sobre HIV e aids em nível razoável, alguns pacientes consideravam a infecção pelo HIV como uma morte social e física (destaque dos autores). Isso os impediu de usar o conhecimento do seu status 
sorológico de forma construtiva, favorecendo sua negação e o sigilo sobre ele. Essas estratégias evitativas os desencorajaram a fazer uso de medidas de prevenção e proteção da saúde, deixando-os mais vulneráveis. $\mathrm{O}$ aconselhamento rápido $\mathrm{e}$ padronizado mostrou ser insuficiente, neste caso, para prover o cliente de uma maneira efetiva de enfrentamento da infecção pelo HIV. As pessoas soropositivas apresentam necessidades e problemas que aparecerão com o tempo, requerendo-se que o aconselhamento esteja disponível tanto na fase inicial, como no decorrer do tempo.

A forma como o usuário é recebido e acolhido pela equipe de saúde desde a sua entrada é determinante para sua permanência e seguimento do atendimento como um todo. A relação de confiança é criada na medida em que ele é respeitado pelos profissionais, é atendido em suas dúvidas e necessidades, e não é discriminado. Dessa maneira, fica assegurado que ele pode recorrer ao serviço quando necessitar. Observa-se que, às vezes, as dificuldades de adesão ao tratamento estão associadas à dificuldade de elaboração psíquica do diagnóstico de HIV positivo, que pode se manifestar em diferentes fases do tratamento (SANTOS, NASCIMENTO, FELIPE 2000).

A prática instrumental utilizada para que o acolhimento e atenção ao usuário referidos acima se concretizem é o aconselhamento, seja ele individual ou em grupo. Ele é definido como um "processo de escuta ativa, centrado no contato direto com o cliente. Pressupõe a capacidade de estabelecer uma relação de confiança entre os interlocutores, visando o resgate dos recursos internos do cliente para que ele mesmo tenha a possibilidade de reconhecer-se como sujeito de sua própria saúde e transformação" (MINISTÉRIO DA SAÚDE 1999a, p.12).

De acordo com essa definição, espera-se que o aconselhamento mobilize recursos internos no cliente, possibilitando uma busca de cuidado com a própria saúde que inclua a adoção de práticas de prevenção mais seguras em relação ao HIV. Além disso, o aconselhamento tem o propósito de sustentar a angústia do usuário em relação ao diagnóstico positivo para o HIV. Nesse sentido, há que se abrir espaço para uma escuta que possibilite ao cliente a veiculação de sentimentos decorrentes do fato de ter tido o resultado do seu teste anti-HIV revelado, podendo também tratar de 
aspectos ligados a situações de sua vida pregressa relacionadas ao resultado.

São objetivos ambiciosos que, para serem alcançados, exigem dos profissionais que o realizam além de preparo técnico, sensibilidade e motivação. Assim colocado, o aconselhamento permitiria um espaço dilatado para acolher o sofrimento que um teste sorológico positivo pode causar a um indivíduo, visando produzir um efeito transformador em direção ao cuidado à saúde.

Torna-se, no entanto, difícil apreender e identificar os efeitos produzidos nos sujeitos em quem incide o aconselhamento, pois a forma como o CTA está organizado não favorece a criação de vínculos mais duradouros para acompanhamento dos casos. Os CTA se estruturaram como unidades de saúde de "passagem" - quando não fazem parte dos serviços de assistência em DST/Aids. Funcionam como uma espécie de "porta de entrada" para o sistema de saúde. O formato do serviço é desenhado para que o cliente marche em direção a outros níveis de atenção na hierarquia do sistema de saúde, assim que é revelada a sua soropositividade. Em contrapartida, supondo que um ou dois encontros não sejam suficientes para lidar com as questões suscitadas pela condição soropositiva, como viabilizar que a oferta de mais aconselhamentos seja concretizada, sem alterar a estrutura organizacional e a natureza dos serviços?

Reflexões tornam-se necessárias a respeito dessas e de outras questões envolvendo o trabalho nos CTA. Um exemplo dessa necessidade é o fato de que, no cotidiano destes serviços, observa-se que determinados clientes realizam periodicamente testes sorológicos com sucessivos resultados negativos. Isso pode sugerir que eles estão expondo-se continuamente a situações de risco de infecção pelo HIV, e não estão apreendendo e/ou colocando em prática as informações de prevenção. Entretanto, pode haver também outra explicação a ser pesquisada, como a verificada no estudo relatado por AGGLETON (2006): em um survey realizado no Reino Unido em 2004, descobriu-se que homens que haviam se infectado recentemente nem sempre esperaram se tornar HIV positivos, apesar de praticarem formas de sexo que eles sabiam oferecer riscos. Ter resultados negativos de sorologias para o HIV anteriores era considerado como prova de imunidade, ou 
ainda, que as práticas de redução de riscos (tais como ser o parceiro ativo no sexo anal) estavam funcionando.

Outra questão que se coloca é que os profissionais que realizam o aconselhamento são oriundos de formações também diversas: são psicólogos, assistentes sociais, enfermeiros, médicos e educadores de saúde. Em decorrência de um viés formativo, no desenvolvimento das ações eles podem focalizar o aconselhamento nas dimensões pedagógicas, psicológicas ou de inserção e adaptação social. Suas intervenções podem ter também o caráter mais prescritivo ou mais construtivo, dependendo de suas abordagens, embora as capacitações para a prática de aconselhamento os tenha preparado para não se descuidarem dos objetivos que devem ser alcançados neste processo.

Assim, múltiplos são os desafios que podem acometer os profissionais e gestores, uma vez que as práticas de saúde (incluindo o aconselhamento) caracterizam-se pelo seu caráter relacional, produtor da intersubjetividade. Essa precisa ser mais bem compreendida em sua multiplicidade de significações.

A idéia que se pode depreender dessas considerações é a de que o processo de aconselhamento possui uma dimensão multifacetada, pelas diversas características tecnológicas e humanas envolvidas nele. É um instrumental cuja aplicação é cada vez mais consolidada, mas que não dispensa cuidados e aperfeiçoamentos no seu uso. Sua concepção como tecnologia de aplicação e utilização aparentemente simples revela-se, assim, como bastante sofisticada em função de sua realização por vários participantes: diferentes instituições, diferentes aconselhadores e diferentes clientes.

Além das questões já colocadas, outras podem ser formuladas em função do que se espera do aconselhamento sorológico pós-teste:

1. O aconselhamento sorológico realizado nos dois CTA envolvidos no estudo possibilita ao cliente uma escuta de suas preocupações e sentimentos decorrentes da comunicação do resultado positivo para o HIV?

2. O aconselhamento sorológico fornece ao cliente os subsídios informativos necessários para avaliar sua situação de risco singular e para a apropriação de práticas preventivas em relação às DST e aids? 
3. O que os clientes têm a dizer sobre o modo como foi feita a comunicação do seu resultado sorológico positivo ou o seu aconselhamento pós-teste?

4. É possibilitado ao cliente ser colocado no lugar central no seu próprio aconselhamento sorológico?

5. A concepção do aconselhamento, como tecnologia de apoio e prevenção, é refletida no cliente? Existe uma percepção dos clientes a respeito do preparo técnico envolvido no aconselhamento?

São essas as questões que motivam a elaboração do presente estudo. O intuito de se fazer uma investigação como esta é o de poder refletir sobre as visões e percepções dos clientes que passaram pela experiência de aconselhamento em dois CTA na cidade de São Paulo e, por meio de suas falas, poder também ouvir as vozes dos seus aconselhadores.

Para iniciar a busca de respostas a essas indagações, fez-se uma pesquisa ao que já existe na literatura da área, tanto a bibliografia relativa ao tema do aconselhamento sorológico e à realização do teste anti-HIV, como a bibliografia relacionada à revelação do resultado positivo.

Em seguida, apresentam-se as bases conceituais do processo de aconselhamento, com um breve histórico sobre sua origem, desenvolvimento e aplicação no campo da psicologia, e posteriormente no campo da saúde, especialmente na prevenção das DST e HIV.

Por se tratar de um estudo que pretende refletir sobre a intersubjetividade que envolve a prática de aconselhamento, a teoria psicanalítica é o referencial de escolha. Alguns desenvolvimentos teóricos de autores são apresentados nos dois subtítulos seguintes, em especial os de Armando Bauleo e Donald W. Winnicott, que se preocuparam com o campo intersubjetivo. Suas teorizações desenvolvidas a partir da prática clínica auxiliarão na análise interpretativa dos dados. Encerra-se o capítulo introdutório com a elaboração da justificativa e da hipótese que sustenta a realização deste estudo, e a utilização dos referenciais teóricos de análise escolhidos.

No Capítulo 2, são expostos o objetivo geral e os específicos sobre os quais se desenhou a investigação. 
O Método é apresentado no capítulo seguinte. Nele é explicitada a parte operacional do estudo, desde os aspectos teórico-metodológicos da coleta de dados, do trabalho de campo, e do encontro com os voluntários para a realização das entrevistas. Uma breve descrição dos serviços envolvidos e da população de estudo também encontra-se ali, bem como os aspectos éticos e a técnica utilizada para a análise dos dados.

No Capítulo 4, os Resultados são apresentados sob duas formas complementares de análise do material, ambas focadas nos objetivos do estudo. A primeira delas, mais descritiva, relaciona os depoimentos dos entrevistados em temas-eixos em torno dos quais transitaram as entrevistas de pesquisa: a escuta do cliente no processo de aconselhamento, o lugar ocupado pelos entrevistados na comunicação do seu resultado positivo e, por fim, os aspectos da prevenção do HIV e do cuidado à saúde enfocados nos aconselhamentos. A segunda forma de análise pretende ser mais dinâmica, analisando psicanaliticamente $o$ processo de aconselhamento que se operou entre os clientes e seus aconselhadores.

Nas Considerações Finais, o Capítulo 5, procura-se estabelecer um diálogo entre os clientes, aconselhadores, os serviços de testagem e a teoria winnicottiana. Busca-se, então, evidenciar o impacto e os subsídios que o presente estudo pode oferecer para melhor compreender o modo como se estabelece o espaço de interação para a revelação do teste sorológico positivo no contexto do aconselhamento nos CTA. A versão dos clientes pesquisados poderá proporcionar a indicação de novos caminhos para os desafios colocados na realização desta prática de saúde.

Por último, estão colocadas as Referências Bibliográficas e os Anexos.

\subsection{REVISÃO DA LITERATURA}

A busca por publicações foi realizada através da Biblioteca Virtual em Saúde, começando pela pesquisa mais ampla sobre o descritor de assunto "aconselhamento" e, em seguida, fazendo o refinamento por meio do cruzamento com os descritores: "HIV", "AIDS" e "testagem".

O resultado da busca geral totalizou mais de vinte mil trabalhos, envolvendo todas as bases de dados da literatura científica. Quando se fizeram os cruzamentos 
entre os descritores citados, dois a dois, o número caiu para cerca de dois mil trabalhos em cada pesquisa. Fazendo a combinação dos quatro descritores ao mesmo tempo, o resultado da busca foi de cerca de noventa trabalhos. A partir desse resultado, foi feito um outro refinamento por meio da seleção das bases de dados de maior interesse para o estudo: a base "Ciências da Saúde em Geral” integrada pelo sistema LILACS (Literatura Latino-Americana e do Caribe em Ciências da Saúde) e pelo sistema MEDLINE (Literatura Internacional em Ciências da Saúde). O resultado dessa seleção foi a obtenção de cerca de sessenta trabalhos, cujos resumos foram selecionados e lidos um a um, procurando-se recuperar na íntegra os trabalhos de maior interesse para o estudo.

A OPAS/OMS (Acervo da Biblioteca da Organização Pan-Americana da Saúde e Sistema de Informação da Biblioteca da Organização Mundial da Saúde) e a biblioteca virtual do Ministério da Saúde do Brasil foram consultadas para a obtenção de documentos e publicações oficiais (já referidos na introdução), assim como o Portal do Conhecimento da Universidade de São Paulo.

Observou-se que os trabalhos relacionados direta e especificamente com o objeto do presente estudo apresentam limitações quanto à sua execução. A explicação para os limites deste tipo de estudo é fornecida pela Organização Mundial da Saúde quando, baseada em informações enviadas por programas de diferentes países, elabora o documento intitulado: "O impacto do aconselhamento e do teste voluntário. Panorama em escala mundial dos benefícios e dificuldades". "Os serviços de testagem e aconselhamento que estão à disposição de numerosos grupos diferentes de pessoas em situações diversas, têm objetivos que variam consideravelmente. Por isso é difícil e, às vezes, enganoso comparar as intervenções de TAV (Testagem e Aconselhamento Voluntário)" (ONUSIDA 2002, p. 8). Nesse documento é apresentado um quadro com os problemas colocados pela comparação das intervenções, assim resumido: diversidade das intervenções, fatores susceptíveis de influenciar os resultados das intervenções de TAV, diversidade de populações envolvidas e considerações sobre o tempo (envolvendo o momento escolhido para avaliar o serviço e o estágio e amplitude). Apesar das dificuldades, o relatório aponta que a maioria dos estudos indica que a TAV é benéfica. 
$\mathrm{Na}$ revisão do presente estudo, os trabalhos foram organizados em dois tópicos, de acordo com sua especificidade de enfoque sobre: (i) a testagem e o aconselhamento, e (ii) a comunicação do resultado do teste HIV positivo.

\subsubsection{Sobre a Testagem e o Aconselhamento Sorológico}

Investigações envolvendo tanto abordagens baseadas no modelo de mudança de comportamento quanto abordagens cognitivas (ambas, modelos teóricos de aconselhamento) foram empreendidas em várias partes do mundo.

Estudos procuraram avaliar a eficácia da TAV na prevenção do HIV, especialmente no que tange ao aumento do uso do preservativo nas relações sexuais, comparando: (i) grupos de solteiros com grupos de casais divididos ao acaso entre os que fizeram TAV e os que receberam informações de saúde ("The voluntary HIV-1 counseling and testing efficacy study group" 2000); (ii) grupos de mulheres afroamericanas de baixa renda que realizaram testagem e aconselhamento com grupos de mulheres que não realizaram (ST LAWRENCE e col. 1998), e (iii) clientes de uma clínica de DST com homens gays e com usuários de drogas injetáveis (SPIELBERG e col. 2001). A sugestão feita pelos autores desse último estudo é a de que algumas estratégias devem ser implementadas para prover a aceitação de se realizar o teste, tais como: reconhecer medos e barreiras, utilizar tecnologias de testagem disponíveis e expandir as opções de aconselhamento. Entretanto, o estudo não apresentou diferenças entre as populações envolvidas, o mesmo ocorrendo com o estudo envolvendo mulheres, desenvolvido por ST LAWRENCE e col. (1998). Em contraste, a comparação entre solteiros e casais mostrou diferença e, apesar das especificidades quanto ao comportamento dos sujeitos em cada grupo, houve, no geral, uma maior diminuição de relações sexuais desprotegidas entre as pessoas que se submeteram à TAV do que entre as que receberam informações de saúde ("The voluntary HIV-1 counseling and testing efficacy study group" 2000). Os autores desse grupo de trabalho concluíram que a testagem voluntária e o aconselhamento são medidas eficazes para promover mudança de comportamento e prevenção.

SWEAT e col. (2000) apontam que, em países menos desenvolvidos, o acesso à TAV ainda é limitado e a sua necessidade aumentará significativamente quando as 
terapias antivirais tornarem-se mais amplamente disponíveis. Os resultados do seu estudo mostraram que evitar a infecção pelo HIV-1 através da testagem e aconselhamento voluntário tem uma relação custo-benefício relevante. Apesar dessa constatação e da factibilidade dessa prática demonstrada no estudo de ISEZUO e ONAYEMI (2004), muitos países ainda não implementaram a TAV na rotina dos serviços e os pacientes são testados sem ter acesso ao aconselhamento antes e após a testagem.

O estudo de REILLY e WOO (2003), realizado em Nevada (EUA), envolveu 360 adultos HIV soropositivos e mostrou que a prática sexual desprotegida estava relacionada à insuficiência do número de serviços e à quantidade de necessidades não alcançadas. Mesmo tendo sido consideradas as diferenças de gênero e etnia observadas no estudo, a maior proporção dos indivíduos que optaram por sexo desprotegido reportou uma maior necessidade de aconselhamento psicológico e suporte social. Estes achados apontaram uma ligação importante entre acesso aos serviços e o ato de evitar comportamento sexual de alto risco pelas pessoas soropositivas.

Assim, é necessário pensar em políticas que melhorem o acesso das pessoas ao serviço de testagem e aconselhamento e, além disso, que o desenvolvimento dessas ações seja guiado por pesquisas sobre sua eficácia e por diretrizes de políticas nacionais (MEURSING e SIBINDI 2000).

LINDGREN e col. (1998), ao analisarem a redução da transmissão maternoinfantil em gestantes soropositivas que passaram por testagem e aconselhamento, apontam para a necessidade de implementação dessa prática nos serviços, para que essas mulheres tenham mais condições de enfrentar as conseqüências negativas do HIV que estão relacionadas com a aceitação do diagnóstico e a imediata adoção da terapia medicamentosa. Ainda visando encontrar formas para lidar melhor com o diagnóstico e com o início do tratamento, KILMARX e col. (1998) realizaram entrevistas com pessoas recém-diagnosticadas, a partir das quais sugerem que as equipes façam contato com os clientes soropositivos, rotineiramente, após o aconselhamento pós-teste. Segundo esses autores, isso favoreceria a inclusão e acesso dos clientes aos serviços de saúde. 
Existem estudos que focalizam o acompanhamento das pessoas após serem diagnosticadas como soropositivas, analisando os efeitos de intervenções sobre a qualidade de vida dessas pessoas (MOLASSIOTIS e col. 2002; HSIAO e col. 2004).

No primeiro estudo, MOLASSIOTIS e col. (2002) investigaram os efeitos da terapia de grupo de base comportamental/cognitiva e do apoio/aconselhamento de pares na diminuição do sofrimento psicológico e na melhoria da qualidade de vida em pacientes chineses com infecção por HIV sintomática. O estudo comparou grupos de pacientes que receberam ajuda psicológica e outro grupo de pacientes que receberam tratamento de rotina, sem intervenção psicológica específica. Esse estudo demonstrou que o acompanhamento subseqüente dos casos por meio de intervenções psicológicas pode diminuir o sofrimento psicológico e melhorar a qualidade de vida, indicando que deve ser incorporado ao manejo do cuidado às pessoas vivendo com HIV.

O segundo estudo (HSIAO e col. 2004), realizado em Taiwan, envolveu soropositivos recém-diagnosticados e teve por objetivo compreender como as intervenções de aconselhamento afetam a qualidade de vida das pessoas. Foi utilizado o método quase-experimental ${ }^{*}$ em três etapas de entrevistas ao longo de 45 dias. Os resultados mostraram que as técnicas de aconselhamento por etapas foram efetivas para ajudar esta população a se adaptar ao estresse (emocional, social, físico e ambiental) associado à nova condição soropositiva diagnosticada. Os pesquisadores sugeriram que o aconselhamento por etapas seja implementado em hospitais e clínicas que atendem aos pacientes taiwaneses, para promover habilidades adaptativas e controlar a disseminação do HIV.

SLIEP e col. (2001) conduziram uma pesquisa para explorar e descrever a experiência de pacientes HIV soropositivos com sua doença no contexto rural de Malawi. Foram utilizados, como procedimentos metodológicos, entrevistas com pacientes e grupos focais com aconselhadores. Os resultados do estudo serviram de

\footnotetext{
* Esse procedimento metodológico implica em realizar uma intervenção e em não alocar aleatoriamente os indivíduos na formação dos grupos de comparação. A análise e interpretação dos resultados nesse tipo de estudo separam os efeitos da intervenção que se pretende avaliar dos demais efeitos, em especial, dos efeitos devidos à não-comparabilidade inicial dos grupos. A interpretação dos resultados de um estudo quase-experimental é semelhante à de um estudo de observação, e relativamente distante da interpretação de um estudo randomizado ou experimental (PEREIRA 2005, p. 284).
} 
base para a formulação de um modelo de aconselhamento e de um roteiro para sua implementação. A capacitação foi considerada essencial para que pudesse atingir as necessidades internas e externas dos pacientes. Os autores usaram como paradigma algumas teorias que enfatizam o contexto cultural e social específico num determinado tempo e espaço, e diferentes disciplinas foram incorporadas ao estudo.

Há estudos com o objetivo de investigar como a técnica de aconselhamento é utilizada nos serviços. Esses estudos envolveram além dos pacientes, também os aconselhadores (SLIEP e col. 2001, já referido; ROHLEDER e SWARTZ 2005; RUDY e col. (2005); VOLLMER e VALADEZ 1999). Esses estudos apontam a necessidade de investir em treinamento e capacitação de aconselhadores para lhes possibilitar: (i) tratar de questões enfrentadas nos seus locais de trabalho com os clientes e com a própria instituição (ROHLEDER e SWARTZ 2005); (ii) refletir sobre a melhora da qualidade de alguns serviços de testagem e aconselhamento, uma vez que muitos entrevistados reportaram a escassez do tempo despendido pelos aconselhadores, bem como a falta de resposta a algumas das questões feitas (RUDY e col. (2005); e (iii) solucionar os problemas encontrados diante da tarefa de aconselhamento, identificando os fatores e problemas psicológicos mais freqüentes apresentados pelos clientes, que podem servir de base para os treinamentos de aconselhadores (VOLLMER e VALADEZ 1999).

Estudos brasileiros apontam para a importância do aconselhamento para conscientizar a população sobre comportamento sexual seguro (YAZLLE e col. 1999), oferta de sorologia para HIV e sífilis (MOHERDAUI 2000), e melhoria da acessibilidade de um número maior de usuários ao serviço (BETINI 1997). Esse último trabalho, realizado em um CTA de São Paulo - unidade envolvida também no presente estudo - versou sobre a proposta individualizada de aconselhamento que possibilita atender à diversidade de demandas da sociedade. BETINI aponta para a importância da informação no contexto social, político e cultural contemporâneo. Ela observa que, no caso da aids, a informação é vital, aliada às formas possíveis de redução de vulnerabilidade frente à infecção pelo HIV.

No que concerne às populações específicas, alguns trabalhos apresentam o aconselhamento de forma a enfatizar as singularidades dos profissionais de saúde 
envolvidos. PECHANSKY e col. (1996) capacitaram multiplicadores, que iriam atuar junto a usuários de drogas injetáveis. Os autores avaliaram o programa após um período de seis meses. A eficácia do programa era baseada na manutenção da soronegatividade dos indivíduos, na mudança nos comportamentos sexuais de risco e uso de droga, bem como na maior conscientização sobre a transmissão do HIV.

Foram desenvolvidos trabalhos com mulheres HIV soropositivas que investigaram, dentre outros propósitos, como elas percebem o aconselhamento sorológico na área de saúde sexual e reprodutiva (PAIVA e col. 2002; LANDRONI 2004; FELICIANO e KOVACS 2004). Constatou-se, no primeiro estudo, que a proporção de uso consistente de preservativos relatada pelas mulheres entrevistadas é três vezes maior que a média nacional, indicando que os programas especializados podem fazer diferença. Elas declararam que recebem dos médicos uma quantidade insuficiente de informação sobre a prevenção da transmissão materno-infantil (TMI), o que pode estar ligado a uma menor qualidade do acolhimento ao direito da mulher soropositiva querer ter filhos. Esse tipo de acolhimento (ou resposta do serviço) parece não ter melhorado com o tempo, mesmo em se tratando de centros de referência estadual ou nacional. "O estudo de MAGALHÃES (1998), realizado em um centro especializado em saúde reprodutiva e não em HIV, e que pretendeu analisar o efeito do aconselhamento sobre uso de métodos contraceptivos entre mulheres portadoras, encontrou o dobro da proporção de mulheres utilizando a recomendada dupla-proteção (destaque das autoras) depois de passarem por aconselhamento que abordava sua vida reprodutiva pós-HIV" (PAIVA e col. 2002, p. 1618). As pesquisadoras concluíram que se deve evitar a lacuna entre o momento do teste, a comunicação do diagnóstico e o seguimento cotidiano nos serviços de atendimento especializado. Consideram que o aconselhamento é um dos dispositivos para isso, como parte de um processo contínuo e adequado a todas as fases da infecção ou da vida da paciente, e requer o treinamento interdisciplinar dos profissionais de saúde, com ênfase nos direitos sexuais e reprodutivos. No segundo estudo (LANDRONI 2004), foram identificadas dificuldades de aconselhamento em saúde reprodutiva, de acolhimento e de incorporação da dimensão cuidadora nas práticas assistenciais. Ainda envolvendo a saúde reprodutiva das mulheres, o estudo exploratório de FELICIANO e KOVACS (2004), realizado em Recife (PE), aponta 
para a ausência do aconselhamento como prática educativa na prevenção maternofetal, predominando a racionalidade estratégica de transmissão de informações. As autoras concluem que isso tem repercussões negativas na vulnerabilidade dessas mulheres e seus filhos.

No estudo de LOPES (2003) essas dificuldades no aconselhamento foram mais acentuadas entre as mulheres negras do que entre as não negras. A autora concluiu que, ao incorporar a categoria analítica raça, pode-se compreender melhor a multidimensionalidade, a instabilidade e a assimetria da vulnerabilidade. As mulheres negras entrevistadas nesse estudo relataram ter mais dificuldade de falar com os profissionais de saúde sobre sua vida sexual após o diagnóstico de vírus HIV do que as não negras.

O aconselhamento com a população adolescente é ainda "um caminho a percorrer", segundo o estudo de PRADO (2004). Essa autora constatou que, apesar desse tipo de abordagem permitir a quebra da cadeia epidemiológica de transmissão de DST, no caso dos adolescentes ele é mais efetivo se realizado fora do espaço ambulatorial. PRADO (2004) sugere que os profissionais se desloquem para os ambientes freqüentados pelos adolescentes.

COSTA (2004) realizou uma pesquisa cujo objetivo foi compreender a prática de aconselhamento em quatro unidades de saúde de Belo Horizonte, pela ótica do próprio aconselhador. Para tanto, a pesquisadora utilizou a metodologia etnográfica.

Também envolvendo aconselhadores, o artigo de BARROSO e col. (2003), sugere que o profissional que realiza o aconselhamento em HIV deve ser um facilitador tanto na conscientização dos sujeitos, quanto na construção de metodologias específicas, adotando uma postura dialógica e transformadora.

FILGUEIRAS e DESLANDES (1999) desenvolveram o estudo de “Avaliação das ações de aconselhamento, sob a perspectiva de prevenção centrada na pessoa" nos CTA, SAE (Serviço de Assistência Especializada em DST e Aids) e em serviços que atendem DST e Aids de várias cidades brasileiras. Os procedimentos metodológicos utilizados foram: entrevistas semi-estruturadas com profissionais de saúde e observações de campo na situação de aconselhamento individual e coletivo 
(antes e depois da realização do teste sorológico).

Os resultados mostraram que há uma diversidade de nomenclaturas para o aconselhamento entre os serviços, bem como de categorias profissionais que o realizam. No geral, observou-se receptividade e acolhimento dos profissionais em relação aos clientes nos aconselhamentos acompanhados na rotina dos serviços. Entretanto, a atividade de escuta foi a diretriz do aconselhamento considerada mais precária e problemática, prejudicando também a avaliação dos riscos do cliente. Os profissionais entrevistados referiram sentimentos de insegurança para lidar com situações inesperadas e temor de que surgissem perguntas sobre as quais não tinham conhecimento adequado para responder, ou que se criasse constrangimento no aconselhamento coletivo. Alguns profissionais não tiveram preparo adequado em sua formação para lidar com algumas questões colocadas na situação de aconselhamento.

A adoção do preservativo nas relações sexuais depende de uma focalização e atenção às singularidades do sujeito, o que nem sempre foi conseguido pelos profissionais. Seus discursos sobre a necessidade do uso do preservativo nem sempre se justificaram, havendo às vezes a desqualificação dos argumentos dos usuários a seu próprio respeito. Questões de gênero nem sempre foram levadas em conta nos aconselhamentos estudados.

O enfoque sobre os aspectos clínicos e de tratamento das DST e aids que visa promover a adesão ao tratamento foi mais fácil de ser observado nos serviços que dispunham de profissionais de enfermagem realizando pré e pós consulta.

Por intermédio desta pesquisa, concluiu-se que, há necessidade de maior capacitação sobre a prática do aconselhamento para centrar a atenção no cliente, personalizando as informações. Foi reconhecida a situação de estresse nos profissionais, provocada pela comunicação do resultado positivo e pelas condições de vulnerabilidade vividas pela clientela, sugerindo-se apoio e supervisão a eles.

FERREIRA e col. (2001) analisam dados de produção (do ano de 1997) de três CTA do município do Rio de Janeiro. Em 1998, foram também aplicados dois questionários semi-estruturados na clientela desses serviços. Os resultados apresentaram o perfil epidemiológico e demográfico desta população. A conclusão do estudo indicou que os CTA têm o aconselhamento como tarefa primordial, por 
meio da qual se pode abordar temas pessoais como a sexualidade, e temas coletivos como o preconceito, os tabus e os direitos sociais. Além disso, o aconselhamento promove a escuta do "sujeito-cliente" (termo utilizado pelos autores), dando-lhe voz e crédito, considerando que “... essa é uma estratégia fundamental, uma vez que sem o engajamento e a participação ativa desse sujeito, poucas são as chances de ampliarmos os comportamentos e valores capazes de evitar as DST e o HIV" (p.489).

Esse trabalho, juntamente com o trabalho de GIRON e col. (2002), valoriza a função dos CTA diante da epidemia de aids e da rede de atendimento do SUS, reforçando a continuidade e maior qualificação desse serviço. O aconselhamento realizado nos CTA, segundo os autores, favorece uma reflexão sobre a sexualidade e os riscos de cada cliente, estimulando-o a encontrar formas de vida sexual mais prazerosa e menos arriscada a contrair DST e HIV. Ressaltam a necessidade de estender a experiência do CTA aos outros equipamentos do SUS para que esses possam também se estruturar para enfrentar a realidade de feminização, pauperização, baixa escolarização e violência estrutural da epidemia da aids que são fatores de vulnerabilização da população.

Encerra-se, assim o relato dos estudos envolvendo a importância da testagem e aconselhamento na luta contra a aids e apresenta-se, a seguir, o capítulo destinado aos estudos envolvendo especificamente a revelação do resultado positivo para o HIV.

\subsubsection{Sobre a Comunicação da Sorologia Anti-HIV Positiva}

Algumas pesquisas realizadas no Brasil mostraram a importância do aconselhamento sorológico na comunicação do resultado positivo para o HIV.

MORENO (2001) na revisão dos textos publicados desde o início da epidemia até o ano 2000 apresentou os trabalhos relativos ao tema da comunicação do resultado do teste anti-HIV apontando para o impacto provocado na dupla profissional de saúde-cliente. Esses trabalhos são resumidos a seguir.

O estudo de CAVALLARI (1997) é específico sobre o tema da comunicação do resultado positivo, e enfocou o modo como o resultado foi comunicado e a dinâmica psíquica que se operou entre os entrevistados e os responsáveis pela 
comunicação. Como referencial de análise, utiliza conceitos freudianos e o conceito de ruptura de campo de HERRMANN (1991). O campo ordena os significados das relações, possibilitando sua apreensão e sua própria produção. Quando o campo é rompido, isso só é percebido pela modificação da relação que evidencia o vazio da organização anterior, promovendo a reestruturação do seu sentido.

O momento da comunicação do resultado foi considerado um acontecimento traumático na vida dos entrevistados por essa autora, e o conhecimento do diagnóstico "provocou [neles] uma ruptura no campo organizador de seu aparato mental.” (CAVALLARI 1997, p.196), revelando emoções e desvelando aspectos inusitados. O grau de desorganização psíquica decorrente do resultado e a possibilidade de reorganização foram diferentes a partir da história de cada sujeito.

A autora considera que a relação com o paciente soropositivo é disruptiva no sentido de fazer vir à tona aspectos não tocados e desconhecidos do inconsciente. $\mathrm{O}$ resultado soropositivo redimensiona o passado e o futuro a partir das possibilidades de interpretação do sujeito no presente. O campo ocorre sempre em relação à forma como é dado o diagnóstico ao cliente, assim como sua ruptura, motivo pelo qual a autora sugere o preparo do profissional que faz a comunicação.

SANCHES (1997) analisou o papel dos médicos e demais profissionais de saúde e comparou nos depoimentos de pessoas soropositivas o quanto a forma de transmissão do diagnóstico ao portador foi significativa para sua assimilação, e para a continuidade de sua vida. A autora constatou que os pacientes esperam que os médicos os vejam como pessoas inteiras que precisam ser ouvidas e respeitadas, e podem ter um papel ativo no tratamento e provocar mudanças. Isso lhes oferece mais possibilidade de recuperar sua força de vida e enfrentar melhor os ataques internos e externos - que virão a sofrer pela nova condição.

O modo como o aconselhamento é realizado permite (ou não) a avaliação da situação de risco singular e a percepção de risco dos clientes. É o primeiro passo para que os sujeitos sintam a necessidade de se proteger de novas infecções pelo HIV e DST. Assim, o trabalho de LEMOS (1998), trouxe uma reflexão a respeito de sua dificuldade em saber sobre a própria condição sorológica, desde a realização do exame até o recebimento do resultado. Essa dificuldade retrata quão complexo é o 
funcionamento psíquico, especialmente no que se refere à consciência de risco dos indivíduos. Isso pode ser evidenciado a partir da comunicação do resultado sorológico e de seu impacto. Aspectos ligados à consciência/percepção de risco dos indivíduos infectados estão presentes desde o momento que antecede a realização do teste anti-HIV, e podem variar conforme o gênero, papel de gênero (ligado à orientação sexual) e situação de risco. Eles remetem às práticas de prevenção e de não prevenção do HIV, à constituição da identidade e aos sentimentos de culpabilidade ou de destrutividade associados à possibilidade de se infectar dos indivíduos.

Investigando a consciência do risco dos seus entrevistados, CAVALLARI (1997) verificou que, dentre os pacientes heterossexuais (homens e mulheres), não havia o sentimento de estarem em risco até haver um motivo para fazerem o exame. Alguns pacientes homossexuais que não se identificavam com a homossexualidade não se viam em risco, enquanto que outros vivenciaram fortemente a consciência da proximidade do risco. Os conflitos relacionados à inclinação homoerótica interferiram na utilização de medidas preventivas. As pessoas com mais preconceito perante a aids vivenciaram maior desorganização frente ao resultado positivo, pois as representações da inclinação homoerótica não estavam associadas à sua identidade e realidade. Essa constatação foi reforçada por AGGLETON (2006) quando considerou que os homens que fazem sexo com homens formam uma população muito diversificada: uns se vêem como "homossexuais" ou "gays", outros, não. E alguns se acham "bissexuais" (destaques do autor). Isso deve determinar formas também diversificadas de aconselhamento pós-teste para abordar o risco de infecção.

Outra especificidade de atitudes frente ao risco foi referida por EKSTERMAN e col. (1992) que realizaram um estudo envolvendo os pacientes hemofílicos. As autoras consideraram que a pessoa hemofílica já possui uma doença incurável e se percebe como pertencendo às fileiras dos que serão prováveis portadores de outra doença sem cura (dentro da concepção vigente na época de seu estudo, a de grupos de risco). Seu "eu" é hemofílico, ele não se sente uma pessoa. A tomada de consciência de fazer parte de um "grupo de risco" para a aids faz com que já viva um "estar infectado" pelo vírus. A nova doença vem selar as deficiências e dificuldades existentes na vida do paciente, inclusive a concretude de ameaça de 
morte. A impressão causada pelas psicólogas nesse relato é a de que, na comunicação do resultado do teste, eles devem dar uma sustentação dupla: para a hemofilia e para a aids, acrescida ao fato de que muitos são crianças e adolescentes, para os quais uma revelação deste teor adquire proporções inimagináveis e imprevisíveis.

Segundo KLOURI (1992), diante do diagnóstico de aids, as reações primordiais de alguns pacientes usuários de drogas entrevistados por ela foram de revolta, com a presença de sentimentos de destrutividade, havendo deliberadamente o desejo de infectar os outros compartilhando seringas e não usando preservativos nas relações sexuais. Com esses comportamentos, poderiam se re-infectar, denotando certa ambivalência. Outros entrevistados tiveram reações de preservação da vida, aproximando-se da realidade por meio da aderência ao tratamento médico, da preocupação com a prevenção e com a saúde de forma geral.

Independentemente da categoria de exposição responsável pela infecção do sujeito, os autores referidos constataram que há um impacto provocado pela comunicação do diagnóstico e é necessário cuidar do modo como é dada a notícia. No momento da comunicação, as falas e atitudes dos profissionais são fundamentais para dar suporte frente ao sentimento de desamparo desencadeado pela notícia e para favorecer a elaboração do diagnóstico. Se a equipe compartilha a responsabilidade desta tarefa, isso pode dar suporte aos pacientes e aos próprios profissionais. Com isso, pode-se, também, abrir espaço para a manifestação dos sentimentos e temores como forma de alívio da angústia. Nos trabalhos apresentados, a colaboração dos familiares e amigos também se mostrou boa coadjuvante na lida com a dor e o sofrimento decorrentes da condição de portadores do vírus da aids.

PESSOA LABAKI (1996) considerou em seu estudo que a aids tem uma posição singular, diferentemente de outras doenças incuráveis. A aids faz com que o médico não se permita o direito de excluir a morte do panorama futuro da vida de seu paciente, pois o seu caráter transmissível obriga-o a falar dela ao portador do HIV. Segundo essa autora, a qualidade de portador sadio incrementa a vivência da morte como possibilidade real, mesmo sem ter havido ainda a manifestação da doença no corpo. Há a recuperação para o portador e para o profissional de saúde da dimensão 
humana de ambos.

Pode-se refletir que o indivíduo vivencie esse momento da comunicação do resultado positivo do teste anti-HIV como tão penoso exatamente pelas suas conseqüências, que podem enfraquecer ou até romper os laços sociais — como foi apontado também no estudo de MEURSING e SIBINDI (2000), já referido. Assim, a dificuldade estaria ligada à ameaça de isolamento e de sofrer estigmatização na relação com os outros, e não, própria ou exclusivamente, pelo enfrentamento da mortalidade que é inerente à natureza humana. Pode-se conjecturar se, com o advento da terapia antiretroviral (que tem permitido o aumento da sobrevida da pessoa infectada), pode ter havido uma mudança quanto a esses aspectos.

$\mathrm{Na}$ direção de uma outra forma de olhar a questão, FERREIRA (1992) procura não caracterizar a revelação e a própria doença como uma sentença de morte, uma vez que muitos portadores do vírus, há muito infectados, levam uma vida saudável e assintomática. O autor tem um outro olhar sobre esses portadores, conferindo-lhes um lugar especial, na medida em que os profissionais de saúde tiveram que desenvolver um instrumental específico para lidar com eles, para além dos existentes. O desejo de estudar e conhecer o mundo pessoal desses indivíduos foi um imperativo para os profissionais que optaram por lidar com esta enfermidade. Assim, pelo sofrimento do outro se reconheceu os próprios preconceitos, angústias e a ameaça aos ideais. Trazer o doente para o centro do foco e atentar para as suas necessidades foram as formas encontradas de enfrentamento da doença, transferindo, de certa forma, o poder médico para a construção do conhecimento em parceria com outros profissionais e com o próprio paciente. Isso lhe confere um lugar de maior autonomia, não mais passivo, contribuindo para fortalecer os preceitos da ética médica.

No intuito de refletir sobre o momento da comunicação do resultado positivo, MORENO e REIS (2002) apropriam-se de alguns conceitos da teoria winnicottiana. O leitor é conduzido, nesse texto, a um passeio por algumas construções teóricas do psicanalista inglês e, ao mesmo tempo, pode perceber suas possíveis ligações com o momento de encontro entre o profissional de saúde e o cliente quando da transmissão de um resultado positivo. Um olhar sobre este momento é ali depositado, ao lado das 
noções de: (i) "confronto clínico", quando o profissional se vê lado a lado com seu cliente, sem hierarquia; (ii) "trauma", quando há quebra de continuidade na vida de um indivíduo; (iii) "falso e verdadeiro self", quando recursos defensivos são utilizados frente a situações de dor e sofrimento; (iv) a noção de "cuidado", se sobrepondo à noção de "cura"; (v) o "suprimento adaptativo", noção desenvolvida por WINNICOTT (1967b), para se referir ao acontecimento da relação mãe-bebê, quando a mãe apresenta os objetos na dosagem adequada ao mesmo, funcionando como um agente adaptativo por meio do qual o bebê pode entrar gradativamente em contato com as situações de frustrações e de conflito com a realidade. Certamente, não se trata de apenas um momento, mas de toda a emergência da vida afetiva do bebê, apoiada no cuidado da mãe suficientemente boa.

A proposta do artigo foi que, no momento da comunicação do resultado positivo, haja um encontro com o cliente, no qual o profissional se coloca num lugar não invasivo. Dessa forma, será possível ao cliente entrar em contato com seus aspectos mais saudáveis e com sua criatividade, que é o que lhe possibilitará solucionar os problemas que advirão em conseqüência do seu estado soropositivo.

O presente trabalho também lançará mão dessas teorizações, que serão abordadas novamente mais à frente, no capítulo teórico.

A seguir, são apresentadas as bases conceituais do aconselhamento, dando ênfase à teoria rogeriana.

\subsection{ASPECTOS CONCEITUAIS DO ACONSELHAMENTO}

Desde o começo do século XX várias teorias de aconselhamento foram desenvolvidas. Inicialmente, nos Estados Unidos, o aconselhamento foi utilizado como dispositivo da assistência social, oferecendo apoio a problemas financeiros e oportunidade de expressão e alívio das tensões e angústias. Em 1908, Frank Parsons inaugurou em Boston um dos primeiros centros de aconselhamento em instituições municipais - o Centro de Orientação Juvenil. Ainda nos Estados Unidos, houve a criação de serviços de Higiene Mental para adultos e de Centros de Aconselhamento Pré-matrimonial e Matrimonial, que ofereceram campo para a ampliação das técnicas de aconselhamento. (SCHEEFFER 1976a). 
Nos anos 40, ROGERS (1974a) apresenta uma teoria como suporte à prática de aconselhamento que propõe a inclusão da pessoa no centro do dispositivo terapêutico, iniciando uma das grandes correntes do aconselhamento. O processo de aconselhamento é assim formulado por ele: "... a consulta psicológica eficaz consiste numa relação permissiva, estruturada de uma forma definida que permite ao paciente alcançar uma compreensão de si mesmo num grau que o capacita a progredir à luz da sua nova orientação" (p. 29).

Nessa citação, pode-se perceber a intenção de designar a "consulta terapêutica" — no original, "counseling" — como uma modalidade de atendimento psicológico não diretivo, que visa ofertar ao indivíduo a sua autonomia. Um percurso foi feito pelo autor em sua prática desde seu livro Counseling and Psychoterapy: Newer Concepts in Pratice (1942), no qual ele próprio aponta a definição do trabalho do conselheiro (habituado a dar conselho) como orientado diretivamente. Contudo, ele próprio critica a figura do conselheiro identificada como aquele profissional que “... escolhe o objetivo a atingir e intervém na vida do indivíduo para assegurar que ele se dirija nessa direção" (ROGERS 1974b, p. 34).

A opção pelos escritos desse autor, no presente estudo, justifica-se por ser ele precursor e defensor dessa modalidade de consulta, e por seus trabalhos serem citados em alguns documentos, produzidos por instituições governamentais, a respeito do aconselhamento como a técnica preconizada para o trabalho em centros de testagem do HIV (MINISTÉRIO DA SAÚDE 1999a, 1999b).

A influência rogeriana sobre o uso do aconselhamento como um instrumento de apoio psicológico foi grande. Até o advento de seus desenvolvimentos teóricos, predominava a ênfase nos aspectos práticos do aconselhamento, ligados ao método e à natureza geral do processo. Ao elaborar sua teoria centrada no cliente com enfoque na não diretividade, o autor salienta a necessidade de se criarem postulados teóricos que fundamentem os fenômenos ocorridos no aconselhamento (SCHEEFFER 1976b).

A partir desses trabalhos de ROGERS desde 1942, inicia-se uma discussão acerca da tendência a identificar o aconselhamento com a psicoterapia. Sua doutrina apresentava aos aconselhadores uma técnica não-psicanalítica de psicoterapia, 
permitindo-lhes uma abordagem diferente das abordagens de aconselhamento utilizadas até então. A prática do aconselhamento desenvolveu-se em torno dos trabalhos de orientação educacional e profissional com estudantes e baseava-se no ponto de vista de que o indivíduo constitui um padrão único de capacidades e potencialidades que podem ser identificadas por meios de testes psicológicos, e tais capacidades estão relacionadas às diferentes atividades profissionais. Seu uso como instrumento de aprendizagem, de forma a ensinar o aconselhando a pensar bem para alcançar um nível ideal em suas realizações pessoais e em todos os aspectos de sua vida mantinha o traçado da diretividade (SCHEEFFER 1976b).

$\mathrm{Na}$ concepção rogeriana, o aconselhamento e a psicoterapia não poderiam ser diferenciados, pois para ele os princípios que fundamentam ambos os processos são os mesmos princípios que fundamentam as relações humanas construtivas (como é a psicoterapia). Essa discussão permanece, pela existência das duas posições, havendo uma tendência a considerar aconselhamento e psicoterapia como atividades diversas (SCHEEFFER 1976b, p. 17).

É a origem humanista (que considera os seres humanos positivos e capazes de buscar o próprio crescimento e auto-realização) que está na base da construção da teoria de aconselhamento rogeriana e de sua concepção de aconselhador. Assim, no aconselhamento centrado no cliente, o profissional não aprende como fazer $o$ aconselhamento: ele aprende como ser um aconselhador (PATTERSON e EISENBERG 2003).

ROGERS (1974b) considera que a utilização de um "método" (destaque do autor) pelo aconselhador está destinada ao fracasso, a menos que isso faça parte de suas atitudes. Em outras palavras, ele sugere uma atitude autêntica [o destaque é nosso] do profissional que assume esta tarefa de aconselhar. Esse autor também propõe que se chame a pessoa atendida de cliente - na falta de um termo melhor, segundo ele —, na tentativa de proporcionar-lhe um lugar mais auto-centrado do que lhe é dado quando se usa o termo paciente. Nos serviços da rede de saúde do Município de São Paulo, a pessoa atendida é designada como usuária.

Um dos contextos da proposta rogeriana, como foi salientado, é o da psicoterapia, distinto daquele que o presente estudo focaliza. Contudo, pode-se 
pensar em suas proposições direcionadas a outras situações igualmente centradas no cliente, como é a comunicação do diagnóstico soropositivo. Ele próprio utilizou este dispositivo em contextos educacionais.

Para ROGERS (1974b), a finalidade do aconselhamento é ajudar as pessoas a se integrarem, a se tornarem independentes e amadurecidas para que possam resolver os problemas que surgem em suas vidas. Para isso, o autor parte do princípio de que elas têm a potência dessa capacidade, podendo, no decorrer do processo de aconselhamento, chegar por si mesmas à resolução de suas dificuldades desde que lhes seja oferecida uma atmosfera adequada. O aconselhador deve procurar aceitar e compreender a personalidade do cliente, com os aspectos positivos e negativos que possui, devendo ser capaz de comunicá-los a ele. Essa postura exige uma atitude de aproximação que permita pensar conjuntamente com o cliente. Prioriza-se, portanto, a relação envolvida entre aconselhador-cliente, os conteúdos emocionais mais do que os intelectuais, e, mais do que resolver um problema, habilitar o cliente a tomar suas próprias decisões. Essa forma de proceder incide mais sobre os aspectos presentes do que sobre o passado do indivíduo e a própria experiência relacional é uma experiência de crescimento (ROGERS 1974b, p.41-2).

No processo de aconselhamento existem expectativas a serem satisfeitas, seja da parte do cliente, seja da parte do aconselhador. Essas expectativas variam em função das diferentes necessidades atuais do cliente e nem sempre serão totalmente satisfeitas pelo aconselhador. Apesar da natureza única da interação entre cada cliente e cada aconselhador, há expectativas em relação ao papel do aconselhador. $\mathrm{O}$ seu trabalho no aconselhamento depende: (i) de sua personalidade, incluindo seu conhecimento, prática e necessidades; (ii) do cliente, conforme é percebido por ele; (iii) do momento em que estiver atuando e (iv) da noção do que ele acha que deve fazer e que está relacionada à sua própria capacitação e treinamento para aquela função (STEFFLRE e GRANT 1976).

Ao final, o aconselhamento deve possibilitar que o cliente obtenha mudanças em seu comportamento, no modo de elaborar a realidade e o próprio eu; aumente as próprias oportunidades e evite situações adversas; e utilize o conhecimento e habilidade para tomar as próprias decisões. (PATTERSON e EISENBERG 2003, 
p.20).

O aconselhamento é um instrumento utilizado na área da saúde que visa atender às necessidades de pessoas que procuram ajuda para resolver, em um tempo relativamente breve, problemas que não têm necessariamente profundas determinações do ponto de vista psicológico. Estes problemas podem estar ligados a um contexto específico (e às vezes novo) ao qual elas precisam se adaptar e nem sempre estão preparadas, como por exemplo: mudanças de hábito de vida em decorrência de doenças crônicas, reeducação alimentar ou física e prevenção do HIV.

\subsubsection{O Aconselhamento em DST e HIV}

O aconselhamento em DST e HIV segue na mesma direção do aconselhamento psicológico, no sentido de prover atitude de escuta, de respeitar o sistema de crenças dos indivíduos e de contribuir para que eles tenham confiança nos próprios recursos internos ao tomar suas decisões na vida. A tarefa adicional consiste em que tudo isto se passa no contexto relacionado a ter ou não ter se infectado pelo vírus HIV, ter ou não ter condições de adotar práticas sexuais mais protegidas, poder ou não poder negociar o uso de preservativo com o parceiro e a querer ou não querer se adequar ao esquema de medicação anti-retroviral prescrito. Além dessas, outras condições de vida, saúde e cuidado podem estar presentes ao se remeter à situação singular do cliente que participa do aconselhamento.

Em países como os Estados Unidos e a Inglaterra, no início da epidemia de aids já havia serviços de aconselhamento atendendo grupos de homens que fazem sexo com homens e usuários de drogas. Estes serviços incorporaram o apoio psicológico às pessoas afetadas pela doença, trabalhando questões como morte, conseqüências das infecções oportunistas, luto, etc. No Brasil, essa prática foi iniciada pelas organizações não governamentais (ONG) no âmbito da epidemia de aids, sendo realizado pelas próprias pessoas acometidas pela doença. Pouco a pouco foi se estendendo aos serviços de saúde, na medida em que esses se preparavam para lidar com a aids (MINISTÉRIO DA SAÚDE 1999a, 1999b).

"As ações de aconselhamento realizadas no âmbito dos CTA constituem possibilidade de transformar o cidadão em sujeito de sua própria saúde e de sua 
doença. Permite que ele passe a integrar, na sua experiência pessoal, as informações sobre aids e prevenção, e que encontre alternativas pessoais e coletivas para o enfrentamento das questões propostas pela epidemia” (MINISTÉRIO DA SAÚDE 1999a, p. 9). Essas ações, ao colocarem o cliente como centro e tratá-lo como sujeito, atingirão seus objetivos se levarem em conta as conquistas da humanidade na área dos direitos humanos, especialmente dos direitos sexuais. Nessa área de conhecimento, trabalhos têm sido desenvolvidos propondo um modelo operacional para que os profissionais de saúde disponham de instrumentos em suas intervenções de prevenção do HIV (PAIVA 1998). Estes trabalhos também apresentam uma visão alternativa e positiva dos direitos sexuais, pautada por princípios éticos e por condições capacitantes que envolvem a diversidade sexual, as diversas formas de constituição da família, a autonomia para tomar decisões e a eqüidade de gênero (PETCHESKY 1999).

Como já foi colocado, o aconselhamento é definido como um processo no qual profissional e cliente compartilham de uma situação dual ou em grupo, em que estão frente a frente e um deles tem uma informação que será comunicada ao outro. O espaço de comunicação deve conter um lugar no qual esse outro possa trazer também o seu conhecimento, adquirido ao longo de sua vida. A função do aconselhador constitui-se de uma espécie de moderador, de emissário da informação que será veiculada. Isso pode ocorrer na situação prévia à realização do teste (aconselhamento pré-teste), quando as informações dizem respeito: (i) ao funcionamento e rotina do serviço; (ii) à confiabilidade dos resultados e ao sigilo; (iii) ao direito individual à autonomia e livre consentimento para se submeter ao teste e às eventuais pesquisas desenvolvidas naquele serviço; (iv) à história de sorologias anteriores do cliente; v) ao diálogo sobre dúvidas e informações de prevenção de DST e HIV; (vi) ao uso correto dos insumos de prevenção (material descartável para usuários de drogas injetáveis e preservativos); (vii) indicação de fazer o teste antiHIV em função da janela imunológica e (viii) dependendo do preparo do serviço, à escuta às várias formas de violência eventualmente vividas pelo cliente.

Após fazer o teste - num intervalo de aproximadamente 15 dias - , o cliente participa de uma entrevista (aconselhamento pós-teste), no decorrer da qual conhece o resultado do seu exame. Não está prevista a criação de vínculos longos e/ou 
duradouros, porém o número de encontros é aberto. "Essa é uma característica diferente daquela a que os profissionais da área psicológica estão habituados. A inexistência de um tempo cronológico mais amplo contrapõe-se a um imenso tempo vivido, na medida em que a revelação que a pessoa vem receber tem a dimensão que sintetiza todo o espaço existente entre a vida e a morte. [Não se tem] muito tempo para estar com o usuário, porém, antagonicamente, o espaço desta consulta adquire uma dimensão que não tem tamanho, não se restringe ao tempo físico, cronológico (destaque dos autores). Resta ao profissional e ao cliente a apropriação desse tempo em toda a sua amplitude" (MORENO e REIS 2002, p. 21).

A dinâmica do aconselhamento varia muito em função das pessoas envolvidas: quem é o cliente e quem é o profissional que compõem aquela dupla. Varia, também, em função do resultado ser negativo ou positivo. No caso do primeiro, preconiza-se: lembrar ao cliente que a não infecção pelo HIV não significa imunidade, esclarecer sobre a existência de janela imunológica, quando a pessoa pode estar infectada tão recentemente que o organismo ainda não produziu os anticorpos em quantidade suficiente para detecção no teste e, nesse caso, cabe uma retestagem. $\mathrm{Na}$ comunicação do resultado negativo, o aconselhador deve, ainda, reforçar a importância da adoção de práticas seguras e o benefício do uso adequado dos insumos de prevenção, discutindo sobre a possibilidade de revelação do resultado a terceiros, especialmente aos parceiros sexuais.

É desejável que o aconselhador, diante de um resultado positivo, esteja capacitado para (i) oferecer apoio emocional, possibilitando ao cliente tempo para assimilar o impacto do diagnóstico; (ii) lidar com sentimentos de culpa, rejeição, punição, desmistificando aspectos de degenerescência e morte, dentre outros associados à doença; (iii) diferenciar a condição de portador do vírus da de doente, e informar sobre a necessidade de exames complementares que serão realizados no serviço de referência, ressaltando a importância do tratamento para a aids; (iv) reforçar a necessidade de adoção de medidas preventivas para evitar a reinfecção pelo HIV e outras DST, e a transmissão do vírus a outras pessoas; (v) garantir a aprendizagem do uso de preservativos; (vi) orientar sobre a necessidade de revelar o resultado ao(s) parceiro(s) atual(is), disponibilizando o serviço para isso e para a realização do teste anti-HIV do(s) parceiro(s); e (vii) encaminhar, quando necessário, 
para serviços complementares de assistência médica e de apoio social, incentivando a adesão à terapia medicamentosa (MINISTÉRIO DA SAÚDE 1999a).

O papel desempenhado pelo aconselhador frente à revelação do resultado HIV positivo não é uma tarefa fácil e, neste sentido, os manuais e treinamentos em serviço auxiliam os profissionais. Eles descrevem quais devem ser os conteúdos a serem abordados pelos aconselhadores e quais as atitudes desejáveis e as que devem ser evitadas por eles. Ao seguir o que neles está indicado, os profissionais ainda que bem intencionados, podem se resvalar para uma forma prescritiva de atendimento. Isso às vezes acarreta uma diminuição do espaço de diálogo, em vista da qual o cliente não consegue coordenar a informação que está recebendo com as próprias questões pessoais. Por outro lado, o aconselhador nem sempre consegue ter indícios da apreensão e compreensão dos conteúdos informados, já que ao término da entrevista o passo seguinte já está indicado. Trata-se do encaminhamento para o exame confirmatório, cujo resultado não necessariamente será comunicado pelo mesmo aconselhador. Como não há um seguimento e verificação da compreensão dos conteúdos pelo cliente, este é um dos aspectos que o presente estudo pretende investigar: como o cliente vivenciou o momento da revelação do seu resultado. Que informações ele poderá oferecer sobre isso?

São inúmeras as situações possíveis de compartilhamento e cuidado que se apresentam em um CTA quando há abertura e espaço para acolher o cliente. Caso contrário, o risco é o de se cair na experiência rotineira de trabalho. $\mathrm{O}$ acolhimento é uma das partes constituintes do aconselhamento e é um caminho que conduz à resolubilidade no atendimento. Em se tratando de um serviço de prevenção em DST e aids, as questões trazidas pelos clientes deverão girar em torno desse tema. O profissional que acolhe o cliente abre a possibilidade de interlocução, direcionando o foco da conversa para a demanda que o cliente traz. Concomitantemente, usa o seu saber técnico para auxiliá-lo a encontrar uma resposta possível e autônoma para sua situação-problema.

Portanto, cada atendimento se constrói na medida do seu acontecer e, nesse sentido, é único, marcado pela singularidade da dupla aconselhador-cliente. O aconselhador entra na dinâmica desta relação com sua pessoa inteira, formada pela 
sua história pessoal e profissional. Ele não é um ente desumanizado. Por sua vez, o cliente está ali como uma pessoa singular, e também como pertencente a um segmento populacional, representando a coletividade ou grupo social do qual é oriundo. Assim, é desejável que o aconselhamento se processe de modo a levar em conta os contextos culturais, sociais e psicológicos e os referenciais epidemiológicos de combate à epidemia, inscritos na diversidade que marca a população que comparece aos serviços.

Várias são as condições concretas sobre as quais a intersubjetividade do momento de comunicação do diagnóstico é constituída. São clientes e aconselhadores com histórias construídas ao longo da vida social, cultural e comunitária que interferem neste momento. A constatação de que as pessoas possuem diferentes escolhas sexuais, padrões de vida, valores morais, éticos e estéticos confere a cada encontro de aconselhamento a sua natureza complexa e singular. Adiciona-se a essas condições, a possibilidade de adoecer e morrer que se torna explicitada na tarefa de anunciar o diagnóstico da infecção pelo vírus com o qual o sujeito irá conviver a partir daí.

Sentimentos, representações mentais e forças psíquicas estabelecem continuamente um conflito de vida e morte que se atualiza naquele momento. De acordo com a segunda teoria das pulsões de FREUD (1923) existe um dualismo pulsional que estabelece a luta de forças contrárias advindas de dois tipos de pulsões. A pulsão de vida tenta preservar a vida, enquanto que a pulsão de morte tem a tarefa de conduzir a vida orgânica ao estado inanimado (ou desligado). Ambas as pulsões estão ativas continuamente e em proporções desiguais no psiquismo (p.56). Elas são indissociáveis e só se pode conhecê-las pelos seus efeitos na experiência.

Com base nessa teoria, pode-se dizer que essas forças determinam no sujeito uma luta constante para sobreviver, e estarão presentes no processo de aconselhamento, independente de que demanda ele traga ao serviço. E, para ele, não é fácil expor suas carências e dificuldades e, se está disposto a fazê-lo, é porque espera contar com o saber consolidado e o amparo prometidos pelos profissionais de saúde.

Esses profissionais de saúde estão investidos de autoridade e poder, pois 
possuem o saber suposto pelo cliente e estão colocados em um lugar de sustentação (porque se pretende que sirvam de apoio). No entanto, eles próprios enfrentam o desafio de lidar com suas carências, com a impotência, com a escassez dos próprios recursos, com o próprio preconceito. É importante que esses sentimentos sejam reconhecidos para que eles não sejam espelhados no outro inadvertidamente, pois isso prejudicaria o trabalho visando à redução da vulnerabilidade da população assistida. Por fim, nem sempre os aconselhadores possuem a capacitação técnica suficiente para suportar internamente a própria dificuldade de lidar com a incumbência de revelar o resultado do teste HIV positivo.

Pela existência dessas condições complexas em torno da prática do aconselhamento, busca-se a reflexão e articulação teórica para melhor compreender sua dinâmica. Por essa razão, o presente estudo procurará enfocar noções da teoria psicanalítica, a princípio voltando-se para a compreensão das relações interpessoais nos meandros das instituições de saúde e, posteriormente, aplicando estas noções na situação dual aconselhador-aconselhado. Os dois próximos capítulos discorrerão sobre isso.

\subsection{ENFOQUE TEÓRICO SOBRE O ESPAÇO PÚBLICO INSTITUCIONAL}

“A invenção da psicanálise, o debate sobre o inconsciente, são por uma parte determinados por seu contexto, por formas e lugares de emergência e de 'entendimento' do sofrimento psíquico, pelo 'mal-estar na civilização' e por suas manifestações tópicas, pelas afirmações postas em prática para aliviar alguns de seus efeitos”.

René Kaës

O recurso a KAËS (1997, p. 91) tem por propósito pensar na subjetividade dos lugares sobre os quais incidem as políticas públicas e as ações de saúde que visam lidar com o sofrimento da população. Para esse autor, o método psicanalítico se insere na intersubjetividade para que a interpretação abra o caminho para a compreensão dos efeitos do inconsciente, cujo conhecimento é o seu objeto.

Nos últimos anos, a partir do Ato Constitucional que criou o Sistema Único de Saúde (SUS), sua implantação vem sendo discutida no Brasil e em São Paulo, 
trazendo sempre implícita a importância da participação mais ativa e direta de todos os segmentos envolvidos, especialmente os usuários do sistema. Assim, muitos projetos e programas têm proposto uma mudança nas práticas de saúde, que se traduzem muito mais em valores humanos do que em técnicas. Ouve-se falar em humanização, em acolhimento, em ética. Mas, na prática, do que se trata? Como definir um agir humanizado? Como fazer um bom acolhimento ao usuário? Quando avaliar que um atendimento é ou foi pautado pela ética?

Muitos documentos oficiais têm sido produzidos na tentativa de instrumentalizar, preparar e adequar os profissionais de saúde, objetivando o cumprimento do que é preconizado e a obtenção do ideal de uma atenção à saúde mais digna, ética e voltada para a diminuição da vulnerabilidade e dos riscos da população. Assim, define-se o acolhimento como uma "escuta qualificada" (SECRETARIA MUNICIPAL DE SAÚDE DE SÃO PAULO 2005); propõe-se como modelo de ensino-aprendizagem a "prevenção dialogada" (ABATE 2003); cria-se um programa denominado Humaniza SUS (que logo se transforma em uma política nacional), destinado a garantir a saúde universal, equânime e humanizada, um "... compromisso [que] se traduz no fortalecimento do vínculo, do acolhimento e da co-responsabilidade de todos os envolvidos - cidadãos, profissionais e gestores — nos processos do âmbito do SUS" (MINISTÉRIO DA SAÚDE 2005). Uma das metas do Humaniza SUS é a valorização da dimensão subjetiva e social das práticas de atenção e de gestão.

Apesar da boa intenção, são notórias e enormes as dificuldades, não só de implantação desses princípios e diretrizes, como também é difícil a capacitação e gestão dos profissionais e do sistema. A nomeação da necessidade e da intenção, por si só, não garante sua execução. Ademais, palavras muitas vezes são pronunciadas e repetidas, como se o que representam fosse praticado - o que nem sempre acontece.

Tratando-se do sistema público de saúde, onde são articuladas as políticas (condição de existência das ações), outras dificuldades entram em cena. A título de exemplo, de tempos em tempos se vivenciam mudanças decorrentes dos processos eleitorais, podendo haver um redirecionamento das políticas públicas para objetivos diversos dos anteriores. Inevitavelmente, isso provoca um mal-estar e insegurança 
naqueles que são os porta-vozes e executores das políticas, os trabalhadores da saúde e coordenadores de unidades, influenciando os processos de trabalho e as formações subjetivas nas instituições. Eclodem conflitos de diversas ordens, implícitos ou explícitos, compreensíveis ou não, mas sempre determinantes: de angústia, de sofrimento e de catástrofe (entendida como caos, desorganização e destrutividade).

Desta forma, é importante poder entender os múltiplos sentidos que os fenômenos intersubjetivos podem ter. A idéia de versão parece apropriada para abordar as alternativas de análise (GIOVANETTI 2002, p. 40-1). Segundo essa autora, a psicanálise coloca duas pessoas em situação de uma conversa que busca restaurar as dimensões sedimentadas e esquecidas do sujeito, possibilitando-o escolher mais deliberadamente quem ele quer ser. Assim, o uso da psicanálise é uma possibilidade promissora e valiosa, na medida em que sua proposta visa à abordagem do psiquismo humano em sua expressão mais verdadeira.

Esse referencial constitui uma das vertentes possíveis de enfrentamento das questões tão complexas que as instituições públicas de saúde enfrentam em seu cotidiano. Trata-se de uma vertente que ajuda a sustentar e suportar as dificuldades advindas do trabalho de atender pessoas com demandas diversas, com grande sofrimento psíquico decorrente de condições sociais precárias e inóspitas. Essas demandas são muitas vezes difíceis de serem atendidas em sua plenitude, gerando mal-estar e impotência no espaço institucional. A psicanálise permite também compreender o que subjaz à ação, desvelando sentidos não explícitos e podendo produzir um efeito renovador, esclarecedor e compreensivo na dinâmica institucional, ou seja, pode exercer influência terapêutica sobre os sujeitos atendidos.

Muitos psicanalistas têm se dedicado ao trabalho institucional visando evidenciar os mecanismos que ali operam, de forma a obter um efeito terapêutico por meio da utilização dos instrumentos e dispositivos psicológicos (KAËS e col. 1989, KAËS 1997; COSTA 1991). Pode-se mencionar ainda Bauleo, que, juntamente com Pichon Rivière, acumula uma extensa experiência na realização de análise institucional por meio da supervisão de equipes. BAULEO (1988) elabora algumas reflexões a partir dessa prática, relatando-as em seu livro "Notas de Psicologia e Psiquiatria Social”. 
Esse autor observou, em diversas análises institucionais realizadas, que o problema manifesto na solicitação de análise sempre ocultava a existência de uma tarefa latente. "Desenvolver o latente não é um passe de mágica, de encontrar o oculto, (...) é uma análise sistemática das questões que vão se apresentando ao longo de nosso trabalho, e as interpretações e explicações que podemos proporcionar às condições diferentes pelas quais transitam as relações interpessoais, quando se está realizando tarefas em grupo, em circunstâncias institucionais" (BAULEO 1988, p.115). O autor caracteriza a instituição como sendo formada por vários grupos que se relacionam entre si em função da realização de uma tarefa, formando a rede de relações (o destaque é nosso).

BAULEO (1988) considera a existência de um espaço imaginário constituído por vínculos entre os grupos formados pelos profissionais (terapeutas, no caso da instituição enfocada por ele) e pelos pacientes. Nesse espaço imaginário incidem as fantasias de confrontações mútuas, as comunicações entre os grupos e os atendimentos (as consultas e terapias). $\mathrm{Na}$ instituição em questão, eram criados outros espaços imaginários, como as reuniões de supervisão. Nessas reuniões, as problemáticas tratadas evidenciavam situações de enredamento e, por meio dos discursos entrelaçados, podia-se entender o sentido de alguns sintomas individuais e grupais. De acordo com este autor, esse mundo fantástico (o destaque é nosso) criado necessita de uma concepção de ficção para que se possa decifrar e compreender as relações projetadas entre os participantes da instituição. O resultado deste processo é a sua transformação em instrumento terapêutico (p. 109).

Para desenvolver a prática analítica institucional, apoiou-se em outros autores (LOURAU 1975, LAPASSADE e GUATARI 1982), com a sua idéia de transversalidade como meio de evidenciar o elemento institucional que está presente quando se analisa a situação estabelecida em uma instituição. Em sua concepção, ele acrescenta o caráter operativo, de elaboração de uma tarefa por um grupo de pessoas, que lhe permitiu elaborar sua “... hipótese de trabalho: cada instituição, para levar a cabo sua finalidade, tem uma organização básica intergrupal” (BAULEO 1988, p. 110). É dessa maneira que se constituem os grupos de técnicos, funcionários administrativos e outros profissionais que formam a trama institucional (rede de relações). Para o autor, é nos meandros da estrutura assim constituída que as 
comunicações transitarão: os mal-entendidos, conflitos, fantasmas, os embates internos, os níveis de gestão de poder, as representações mentais desses grupos e da instituição como um todo (BAULEO 1988, p. 110-11).

Para além da instituição em si estão as situações mais amplas, como, por exemplo, a conjuntura e determinação política na qual todo o conjunto se insere e sofre influência. Isso se aplica às instituições que estão envolvidas no presente estudo, e seu objeto está indelevelmente marcado pela trama institucional na qual a tarefa de aconselhamento se opera.

Já foi feita referência neste trabalho aos treinamentos de capacitação realizados no âmbito das práticas de aconselhamento. A intenção dos treinamentos é dar condição de realização da tarefa de forma competente, além de organizar as ações das instituições de saúde. Eles são imprescindíveis, mesmo vindo "de fora". Para que as práticas deles decorrentes tenham a compreensão e aplicação otimizadas, devem ser permeados pela instituição.

$\mathrm{Na}$ análise institucional proposta por BAULEO (1988), o analista ocupa um lugar intermediário, derivado das reflexões em torno do setting realizadas por Winnicott, Bion, Jaques e Bleger (por ele citados). Esta noção serve de suporte para o manejo das ansiedades despertadas pelo processo analítico e também como elemento de elaboração entre um interior e um exterior (p. 119).

As manifestações subjetivas das instituições públicas de saúde podem também ser compreendidas pela crença no ser humano, enquanto potencial de transformação e criação. De acordo com VAISBERG (2002, p.207-8), nessa vertente “... a psicanálise tem efeitos curativos já de saída, pois, repousando sobre uma aposta de que todo gesto humano, por mais sórdido, sublime ou bizarro que seja, pertence, inelutavelmente, ao acontecer humano, $[\mathrm{e}]$ conduz, naturalmente, ao reconhecimento do paciente como semelhante".

Com a intenção de aprofundar a compreensão do processo de aconselhamento sorológico e dando continuidade às considerações teóricas dos psicanalistas já mencionados, apresenta-se, a seguir, uma introdução ao pensamento winnicottiano. Trata-se de uma linha psicanalítica que tem origem na Escola Inglesa de Psicanálise. Segundo ROUDINESCO e PLON (1998), existem seis escolas de psicanálise que 
apresentam aspectos comuns entre si, mas possuem, também, diferenças teóricas fundamentais. Melanie Klein, na Inglaterra, cria o modelo teórico que funda uma linha psicanalítica distinta das demais. Donald W. Winnicott foi o seu seguidor mais ilustre.

\subsection{APORTE DA TEORIA DE D. W. WINNICOTT}

A teorização psicanalítica de WINNICOTT (1951, 1954-5, 1955-6, 1967a, 1967b, 1968, 1975, 1984, 2001), já mencionada na revisão de literatura, é uma opção que torna possível refletir e compreender o momento do aconselhamento sorológico para comunicar o resultado do teste HIV positivo.

O autor iniciou sua carreira como pediatra em hospitais públicos de Londres e, ao longo de anos de experiência atendendo crianças e adolescentes, adotou um tipo de abordagem na qual atentava para os detalhes da situação clínica, desde a forma pela qual a mãe colocava o problema da criança até a maneira como a criança permanecia na consulta. Assim, os atendimentos eram conjuntos: enquanto conversava sobre as demandas da mãe, observava como a criança se comportava e se expressava em relação à mãe e em relação a ele próprio. Ao ler um trabalho de Freud, decidiu iniciar sua própria análise e a formação psicanalítica. Seus atendimentos psicanalíticos seguiram uma linha mais tradicional, porém, em função do número elevado de pessoas que o procuravam (adultos e crianças) sem condições de se submeterem a um trabalho demorado e sistemático, ele desenvolveu uma outra modalidade de atendimento. Conceitos também foram elaborados a partir dessa prática e deram origem a novas formas de atendimento às pessoas portadoras de sofrimento psíquico, utilizando o espaço terapêutico de uma forma mais produtiva. Uma dessas formas é a que ele denominou "consulta terapêutica". Dentre os conceitos e noções de interesse para o presente estudo, tem-se a situação analítica, o setting, e o espaço potencial. Destacam-se ainda as noções de objetos e fenômenos transicionais, suprimento adaptativo e holding.

Assim, tendo por fundamento o campo da experiência clínica winnicottiana, cujo foco está situado no relacionamento mãe-bebê, supõe-se que os resultados deste desenvolvimento teórico sejam passíveis de utilização em outro campo, o do aconselhamento em HIV. Isso se justifica pela postura adotada por este autor de 
propor, ele próprio, a renovação de conceitos e práticas já existentes para a obtenção de uma melhor compreensão do sofrimento psíquico e de melhores resultados terapêuticos. O momento de comunicação do resultado HIV positivo é igualmente um momento de vivência de sofrimento psíquico. Ele tem também em comum com a prática psicanalítica winnicottiana o oferecimento de ajuda e apoio, que se baseia na disponibilidade de escuta. Ambas as situações estão inscritas no campo da experiência intersubjetiva. Contudo, ao se estabelecer este paralelo, não se pretende transformar o espaço do aconselhamento sorológico em um espaço analítico. O que se propõe é que conceitos de um campo de experiência e conhecimento específicos sejam derivados para outro campo, no qual tais contribuições podem se revelar profícuas e produtivas.

Cumpre, então, guardar as devidas proporções e diferenças entre as duas situações, já que, no contexto original da experiência winnicottiana, o bebê é aguardado e desejado pela mãe, ao passo que, no caso da notícia que será revelada pelo aconselhador, ela às vezes é esperada (em termos de probabilidade de acontecer), mas não é desejada. Trata-se de uma situação adversa para ambos, aconselhador e aconselhado.

Segundo WINNICOTT (1955-6), quando se vê uma mãe com seu bebê logo após o nascimento, tem-se que considerar um outro ponto de vista: o do bebê. Este ainda não está diferenciado, na medida em que depende, de forma absoluta, da relação com o meio ambiente e de como este se comporta.

Neste trabalho, pretende-se considerar o ponto de vista do cliente no momento tão delicado e importante do aconselhamento pós-teste. Nessa situação, ambos - aconselhador e cliente - são a princípio desconhecidos um do outro, até que um processo de comunicação se inicie. Para o estabelecimento dessa comunicação é necessário a existência de um ego - uma instância psíquica capaz de oferecer defesas contra a ansiedade provocada pelo momento.

No que se refere ao ponto de vista do bebê, o que está em curso é o processo de identificação primária, que se inicia por uma dependência absoluta em relação à sua mãe. A mãe constitui e representa o ambiente primário do qual a criança depende e intenta se adaptar. A mãe suficientemente boa começa com uma adaptação quase 
completa às necessidades do seu filho, e à medida que o tempo passa, essa adaptação é cada vez menos completa. Concomitantemente, cresce no bebê a sua capacidade de se adaptar ao fracasso da mãe (WINNICOTT 1951, p. 401).

Apoiando-se nessa elaborada noção de mãe suficientemente boa, WINNICOTT $(1951,1970)$ aponta para a preocupação materna primária, como sendo um estado ou uma disposição da mãe que contempla vários aspectos essenciais ao desenvolvimento saudável do ser humano. Estes aspectos estão todos relacionados aos cuidados do bebê: ser alimentado quando tem fome; adormecer quando tem sono e para isso estar aquecido, sem ruído e iluminação excessivos no ambiente; usar determinados objetos para se acalmar, etc. Como já foi dito, a partir de suas observações sobre o desenvolvimento infantil em sua prática como pediatra e como analista elaborou a teoria constituída de alguns conceitos que serão tratados a seguir. Essa teoria proporciona uma compreensão do funcionamento mental que é de fundamental importância para a intervenção do analista, quando ele se depara com as questões clínicas que se lhe apresentam.

Dentre as diversas perspectivas oferecidas pela psicanálise clínica moderna, a de WINNICOTT (1954-5) atribui especial importância ao setting. O setting é o ambiente particular e denso que envolve tempo e espaço, nos quais se desenrolam a produção de fenômenos psíquicos e trocas entre o analista e o cliente, e cujas raízes localizam-se no ambiente materno da infância.

Deve-se levar em consideração as possibilidades oferecidas por esse "ambiente", para se criar as condições para o desenvolvimento do ego, para a organização de defesas contra a ansiedade e para a experiência de apresentação da realidade. Tendo estas condições em mente, o analista orientará a construção do setting no sentido de atender às necessidades do analisando, devendo se preocupar com o manejo do seu trabalho interpretativo. Com pacientes com ego mais intacto, o analista não precisa se preocupar tanto com os detalhes do cuidado materno e o setting não é tão importante em comparação com o trabalho interpretativo. Em contra-partida, WINNICOTT (1954-5, p. 460) explica que, com pacientes cuja estrutura pessoal ainda não está bem fundada, “... a ênfase está certamente no manejo e às vezes o trabalho analítico comum (...) deve ficar suspenso por longos períodos, 
sendo mantido apenas o manejo". Nesse caso, para o autor, o setting torna-se mais importante que o trabalho interpretativo em si, o que não significa que o analista possa prescindir da interpretação como ferramenta.

É nessa espera permitida pelo comportamento do analista que está representado o que WINNICOTT (1955-6) chamou de setting, o conjunto de todos os detalhes do manejo. Ele é suficientemente bom (destaque do autor) quando permite ao paciente uma adaptação gradativa à necessidade, quando é percebido como algo que faz nascer nele a esperança de que o seu self verdadeiro possa finalmente ser capaz de assumir os riscos que a experiência de viver implica.

$\mathrm{Na}$ vida do indivíduo, a situação analítica é considerada como um momento de extrema dependência, devido à sensação de risco que faz com que ele regrida aos processos iniciais do desenvolvimento. "Trata-se de um estado altamente doloroso porque [ele], ao contrário do bebê na situação original, tem consciência dos riscos que a situação acarreta. (...) devemos permitir que o passado do paciente seja o presente. (...) neste trabalho, é mais certo dizer que o presente volta para o passado, e é o passado (destaque do autor)". (WINNICOTT 1955-6, p. 486)

Neste setting assim constituído, o analista é confrontado com o processo primário $^{1}$ do paciente, mas a sua adaptação suficientemente boa possibilita uma mudança nos aspectos desenvolvidos em um ambiente originariamente precário no oferecimento de provisões. E o analista deve ter a sensibilidade para acolher as necessidades do paciente e ter o desejo de prover um setting que atenda a elas. É o que vai favorecer a criação do espaço potencial.

Para que se compreenda como se constitui o setting proposto por Winnicott, é necessário falar do espaço potencial, outra noção desenvolvida por ele e implícita em toda a sua forma de trabalhar. O espaço potencial é a região onde as coisas podem acontecer, podem vir a ser. É uma área estabelecida na fronteira entre o interno e o externo, uma área intermediária, nem dentro, nem fora. O espaço potencial é constituído na medida em que a criança experimenta a falta dos cuidados maternos

\footnotetext{
${ }^{1}$ De acordo com LAPLANCHE e PONTALIS (1970), o processo primário é um dos dois modos de funcionamento psíquico definidos por FREUD, e diz respeito ao sistema inconsciente. Já o processo secundário se refere ao pré-consciente-consciente. O processo primário, ao passar de uma representação para outra sem barreiras de censura, opera pelos mecanismos de condensação e deslocamento.
} 
(no sentido do distanciamento necessário à sua constituição subjetiva), que a mãe vai proporcionando no tempo certo. Esse tempo é constituído na e pela experiência da mãe com seu bebê.

É com a ausência da presença de alguém que a potência humana pode se realizar. Assim é constituído esse espaço potencial. E, permitindo-se a criação do espaço potencial de análise, constitui-se dialeticamente o setting.

O processo se inicia desde as primeiras experiências de adaptação do bebê, quando a mãe lhe apresenta os objetos na dosagem adequada, de modo a the dar o suprimento adaptativo. Assim, a mãe funciona como um agente adaptativo, que apresenta o mundo de forma que o bebê tenha inicialmente um suprimento da experiência de onipotência (destaque do autor). Essa experiência constitui a base de sustentação para que o bebê, mais tarde, aceite gradativamente o que o princípio da realidade lhe impõe (WINNICOTT 1967, p. 13). Enquanto o bebê não estiver em condições de tolerar frustrações e conflitos com a realidade, a mãe aguarda, adiando até que isso seja suportável para o bebê. Está implícita aí a noção do autor de "ambiente facilitador".

"Tentei chamar atenção para a importância, tanto na teoria quanto na prática, de uma terceira área, (...). Localizei essa importante área da experiência (destaque do autor) no espaço potencial existente entre o indivíduo e o meio ambiente, aquilo que, de início, tanto une como separa o bebê e a mãe, quando o amor desta, demonstrado e tornado manifesto como fidedignidade humana, na verdade fornece ao bebê sentimento de confiança no fator ambiental. (...) O espaço potencial entre o bebê e a mãe, entre a criança e a família, entre o indivíduo e a sociedade ou o mundo, depende da experiência que conduz à confiança. Pode ser visto como sagrado para o indivíduo, porque é aí que ele experimenta o viver criativo" (WINNICOTT 1967, p. 142). Estendendo para a situação de análise, para o autor, é importante que o analista se dê conta desse lugar de continuidade-contigüidade, que se encontra onde os fenômenos transicionais se originam e se localiza entre ambos (p. 143).

No desenvolvimento do bebê, o objeto transicional é o que caracteriza a sua união com a mãe. O objeto transicional pode ser localizado no espaço e no tempo em que a mãe se encontra em transição entre estar fundida com o bebê e, ao mesmo 
tempo, de ser percebida (ou concebida, como o autor prefere dizer) como um objeto, caracterizando, portanto, o início de seu estado de separação. Essa é a condição essencial para o desenvolvimento de todos os seres humanos. Os objetos transicionais e os fenômenos transicionais, constituem-se em uma área neutra que não será contestada (WINNICOTT 1951, p. 403).

O objeto transicional possui uma natureza própria, criada e imaginada pelo bebê, que lhe permite percebê-lo como algo que é "não-eu". Sendo "não-eu", o bebê pode ter posse dele e se relacionar com ele. Ao mesmo tempo, o objeto transicional é uma extensão do bebê, uma vez que se localiza fora, dentro e na fronteira (WINNICOTT 1975, p. 14). O termo "transicionais" é introduzido para designar a área intermediária onde esses objetos e fenômenos são experimentados, que é exatamente uma terceira área para a qual contribuem tanto a realidade interna quanto a externa. O ser humano necessita dessa área como um lugar de repouso, que possibilite ao indivíduo manter o interno e o externo separados, ainda que em conexão permanente. Para esse intento, a vivência da ilusão é fundamental.

No caso do bebê, o objeto transicional torna-se importante e é usado por ele nos momentos de dormir, de solidão e de ansiedade, a ponto de não poder se separar dele por muito tempo. Pode ser qualquer objeto de suas relações ou manuseio. Quando o desenvolvimento é saudável, com o passar do tempo o objeto pode ser deixado de usar ou esquecido e difundido na área intermediária.

O objeto representa a mãe e constitui a possibilidade de drible da angústia gerada pela sua ausência. Entretanto, também representa algo do mundo interno do bebê. Aos poucos, o bebê percebe a diferença, e o interno e o externo mostram-se como realidades virtualmente distintas. É quando a desilusão toma gradativamente o lugar da ilusão. A mãe, inicialmente, garante ao bebê a adaptação quase completa às suas necessidades, de tal modo que ele imagina que foi ele que a criou, pois quando ele precisa, ela comparece. É esse o fenômeno chamado pelo autor de ilusão. E é também a experiência de onipotência que aos poucos será frustrada, mas somente quando for possível para o bebê suportar a realidade. "Se tudo corre bem nesse processo gradativo de desilusão, o palco está pronto para as frustrações que reunimos sob a palavra desmame..." (WINNICOTT 1975, p. 28). O objeto transicional permite 
a transição entre o estado de fusão/indiferenciação para o de separação do bebê em relação à mãe.

Quem criou o objeto? Segundo o autor, essa é uma pergunta que nunca deve ser formulada. Simplesmente, se aceita sua existência em um campo - o da ilusão. A mãe faz, a seu modo (suficientemente bom) e gradativamente, a desilusão do bebê.

WINNICOTT (1955-6) reconhece a complexidade e o paradoxo que envolve essa idéia de separação, que é ao mesmo tempo união. Essa área intermediária criada é essencial para o intercâmbio da criança e o mundo e, no mundo dos adultos, é representada pela religião, pelas artes, pelo viver imaginativo e pelo trabalho científico criador. É a área que vai permitir os laços sociais e o viver no mundo compartilhado.

Como foi mencionado no início, as contribuições de Winnicott à psicanálise foram desenvolvidas ao longo de sua clínica psicanalítica tradicional e de seu trabalho como pediatra. Nesse trabalho, ele constatou que nem todas as pessoas portadoras de algum tipo de sofrimento tinham acesso à análise ou precisavam dela. Desenvolveu, então, a "consulta terapêutica" que, de acordo com ele, não pode ser considerada como uma técnica, pois depende exclusivamente do profissional que a utiliza. O que não significa que não existe uma teoria que a sustenta, que é a própria psicanálise winnicottiana.

$\mathrm{Na}$ consulta terapêutica, existe uma superposição da área do brincar do paciente e a área do brincar do terapeuta. Nesse contexto, "brincar" não tem o sentido de jogo com regras pré-estabelecidas. O que determina o "brincar" é a experiência de mutualidade, na qual a flexibilidade e a criatividade do terapeuta são os fios condutores do encontro.

Neste tipo de consulta, ocasionalmente WINNICOTT (1984) realizava mais de um encontro em busca de melhores resultados terapêuticos. Ele descreve que na primeira entrevista com o paciente, ele munia-se de papéis em branco (com tamanhos variados) e de lápis preto, com os quais fazia rabiscos espontâneos que eram complementados pelo paciente. No passo seguinte, o paciente fazia seu próprio rabisco, que WINNICOTT (1984) complementava, formando um desenho. E assim continuava, sucessivamente, até que os conteúdos se aprofundavam por meio desses 
rabiscos e desenhos. Quando as questões específicas do paciente surgiam, eram compreendidas pelo terapeuta e seus significados transmitidos ao paciente. Então, a consulta terminava. Suas entrevistas com crianças eram iniciadas por essa atividade como forma de comunicar-se com elas. Assim, o dispositivo, (denominado "jogo dos rabiscos”) era útil tanto como instrumento diagnóstico quanto com fins psicoterapêuticos.

“A base para este trabalho especializado é a idéia de que um paciente (...) trará para a primeira entrevista uma certa capacidade de acreditar (destaque do autor) na obtenção de auxílio e de confiar naquele que o oferece. O que se necessita desse último é um setting estritamente profissional no qual o paciente fique livre para explorar a oportunidade excepcional que a consulta proporciona para a comunicação”. (WINNICOTT 1968, p. 230)

Com base no que foi exposto, a consulta terapêutica é um dispositivo cuja prática produz efeitos terapêuticos nos clientes que dela participam. Considera-se que poderia ser usada no sentido de produzir derivações para os equipamentos de atenção e assistência em saúde coletiva, notadamente no contexto de aconselhamento sorológico. As noções desenvolvidas por WINNICOTT (1951, 1954-5, 1955-6, 1967a, 1967b, 1968, 1975, 1984, 2001) que são tratadas neste capítulo, são as bases para pensar nessa prática em um setting modificado e voltado para outra finalidade. A intenção teórica e prática é a de prover um ambiente que favoreça a apropriação, tanto do cliente quanto do aconselhador, de seu próprio ser no espaço compartilhado da comunicação do resultado.

O aconselhamento sorológico é uma estratégia para a revelação do diagnóstico positivo do teste anti-HIV. Nos encontros propostos com essa finalidade, essas noções winnicottianas possibilitam um tateio cuidadoso no difícil terreno da intersubjetividade, já que são noções calcadas na sensibilidade do cuidador. É um encontro onde nada é dado a priori, em que cada momento é um momento novo e único a ser construído por duas ou mais pessoas, considerando o contexto institucional no qual ele se realiza. Trata-se de propiciar um ambiente facilitador onde angústias e questões de vida portadas pelo sujeito que recebe o resultado são acolhidas e sustentadas. $\mathrm{O}$ aconselhador entra neste espaço munido da notícia que 
deve transmitir. Essa é uma grande diferença em relação aos papéis e lápis winnicottianos, que não são causadores de impacto. No entanto, o aconselhador (e o cliente) ainda dispõe de sua criatividade e de sua espontaneidade, que constituem o alicerce para a experiência compartilhada. Em outras palavras, pode-se iniciar a comunicação criando um caminho que faça surgir a esperança e o rumo direcionados à saúde, e que demonstre ao cliente que ali é a sua área de descanso, de onde pode sair revigorado.

Dessa forma, o profissional apresentaria uma disponibilidade autêntica para conter os conflitos e a dor do cliente, ao mesmo tempo em que entra em contato com o que ele lhe traz, aproveitando deste espaço e deste tempo para ativar a confiança do cliente. A confiança é o que possibilitará ao paciente fortificar-se e ter acesso ao seu self para, então, progredir no seu próprio desenvolvimento, lançando mão de suas potencialidades. É o espaço potencial winnicottiano.

Neste ponto, é necessário que se diga também algo a respeito da noção winnicottiana designada como holding.

Ao longo de sua vasta experiência atendendo crianças, o autor observou que o ambiente delas é o que sustenta seus passos e sua apropriação do mundo. E isso é feito de forma especial pela mãe, como já foi dito, na medida em que ela introduz o bebê em seus relacionamentos com pessoas e objetos. A mãe o sustenta na medida em que ela se adapta às suas necessidades egóicas. Ela está, com isso, constituindo o holding do bebê. Pois bem, transferindo a imagem para o setting analítico, a essa função (exercida como uma "presença sustentadora" pelo analista) WINNICOTT (2001) considera o holding.

Ele reconhece também a humanidade do analista quando lhe dá permissão para fracassar no exercício dessa função. Exemplifica: "Os analistas com uma moralidade analítica muito rígida, que não permite o toque, perdem grande parte daquilo que está sendo descrito. Uma coisa que eles nunca sabem, por exemplo, é que o analista faz um pequeno movimento sempre que tira um cochilo ou mesmo quando sua mente vagueia (como bem pode acontecer) ele se perde em alguma fantasia própria. Este pequeno movimento equivale ao fracasso do holding nos termos da relação mãe-filho. A mente 'deixou o paciente cair”" (WINNICOTT 1970 
citado por KHAN 1968, p.22).

KHAN (1968) fez essa citação, ao elaborar a Introdução ao livro de WINNICOTT (2001), intitulado "Holding e Interpretação". Ela é bastante oportuna uma vez que esse livro começa pela menção ao sentimento de tédio que pode ser experimentado pelo analista ao ouvir um paciente. Essa afirmação é justificada por (WINNICOTT 2001), na medida em que ele entende que só se pode verdadeiramente

ajudar alguém, quando seu interesse pelo que ele conta mantém-se vivo. É também uma alerta para que os profissionais não se obriguem a realizar um trabalho para o qual não se sintam dispostos.

Nos serviços públicos onde o presente estudo foi realizado, as equipes podem se apresentar em um ambiente que tenha uma função de enquadre, desde que os profissionais contenham o que o paciente lhes apresenta e apóiem-se uns aos outros em suas necessidades de forma compartilhada. Assim, conseguirão oferecer uma escuta que ative recursos do sujeito atendido e sustente suas manifestações diante do seu resultado positivo. Esse é considerado o objetivo primordial do aconselhamento. Segundo a presente proposta, para que isso ocorra, é necessário que cumpram uma função intermediária, segurando o cliente, não o deixando cair.

As construções teóricas sobre os fenômenos psicológicos observados nessas instituições podem ajudar a compreender as dinâmicas evidenciadas no que foi contado pelos sujeitos que participaram do estudo. $O$ uso da psicanálise winnicottiana favorece a escuta, análise e interpretação das histórias de revelação do diagnóstico de Sílvio, Milton, Nei, Luis, Jonas, Juvenal, Arnaldo, Evandro, Cássio, Pedro, Mário, Omar, Paulo e Bruno — os sujeitos entrevistados neste estudo. Antes, porém, é necessário o esclarecimento sobre o porquê da realização do estudo, o que se buscou investigar e como isso foi feito. Adentra-se, portanto, nas bases da construção da pesquisa.

\subsection{JUSTIFICATIVA}

A revisão bibliográfica mostrou que as ações de aconselhamento sorológico no âmbito da epidemia de aids têm sido consideradas como uma das possibilidades de transformar os usuários dos serviços em sujeitos do seu próprio processo saúde- 
doença. É um instrumento que tem sido considerado como de grande valia para a revelação do diagnóstico e para a adesão às práticas seguras, tanto em relação à prevenção primária (adoção do sexo seguro para evitar a re-infecção e transmissão do vírus HIV), quanto à prevenção secundária (adesão à terapia anti-retroviral [TARV]). Portanto, um estudo que investigue as formas como o indivíduo soropositivo vivencia, no exame de HIV, a experiência de conhecer esse diagnóstico por meio do aconselhamento, torna-se relevante para a compreensão e para a própria continuidade, avaliação e aprimoramento deste dispositivo de acolhimento, educação em saúde e cuidado dos CTA. Parte-se do pressuposto de que, podendo constituir um espaço intersubjetivo onde se possa prover o indivíduo de suprimento adaptativo noção já esboçada na seção anterior —, esse apresenta mais condições de sobrevivência física e psíquica. Com isso, espera-se que suas chances de sobrevida, decorrentes da adesão às TARV preconizadas e às práticas sexuais protegidas, sejam aumentadas. Supõe-se que, tendo recebido esse suporte, o indivíduo poderá encontrar formas de bem-estar e de manejo dos sentimentos ocasionados pelo conhecimento do seu status sorológico.

Considera-se que seja possível responder às questões colocadas no presente estudo por meio da utilização das teorizações fornecidas pela psicanálise winnicottiana. A experiência da comunicação da sorologia positiva no contexto do aconselhamento suscita a necessidade de se pensar em maneiras de lidar com o problema, na tentativa de diminuir um sofrimento que não é pequeno, nem tampouco exclusivo do indivíduo que a recebe. $\mathrm{O}$ aconselhamento é o instrumental considerado viável e que está implantado na rede de serviços de DST e aids do Município de São Paulo, cujo estudo propiciará maior compreensão. Tenta-se, assim, utilizar na área da saúde pública institucional parte dos conhecimentos acumulados pela psicanálise em torno do psiquismo humano e do campo social. Afinal, são pessoas cuidando de outras pessoas, e isso estabelece relações que são sobredeterminadas pela constituição subjetiva de cada um dos envolvidos (clientes e aconselhadores), trazendo suas próprias marcas, mediadas pelo espaço institucional e social. Quando se trabalha com saúde, e se quer promover saúde, há que se refletir sobre a melhor maneira de intentar o objetivo. E o espaço potencial winnicottiano é viável de ser instaurado no processo de comunicação do resultado (MORENO e REIS 2002). 
A hipótese que sustenta o presente estudo é a de que, criado um espaço favorável, um ambiente facilitador, ou a terceira área da experiência descrita por WINNICOTT (1967a), a pessoa - agora vivendo com o HIV ou talvez já em fase da aids instalada - terá seus recursos internos ativados para enfrentar a sua própria vida. Dessa forma, os objetivos do aconselhamento, para os quais os aconselhadores foram treinados, terão sido alcançados mediante essa prática. $\mathrm{O}$ aconselhador e $\mathrm{o}$ CTA terão tido um papel importante para aquele sujeito. É o que se pretende investigar por meio da escuta e análise das histórias de revelação do diagnóstico contadas pelos sujeitos da pesquisa.

Considera-se que este tipo de trabalho mostra-se valioso para aquilatar as experiências de aconselhamento sorológico na versão destes clientes. Em adição, os resultados poderão verter também informações para os próprios aconselhadores, os quais, em decorrência de seu trabalho, não dispõem usualmente de instrumentos que evidenciem as vivências subjetivas dos clientes. 


\section{OBJETIVOS}

\subsection{OBJETIVO GERAL}

Analisar as características das interações aconselhador-cliente no processo da revelação do diagnóstico de soropositividade em dois Centros de Testagem e Aconselhamento em DST e Aids do Município de São Paulo, com base na versão dos clientes e tomando por referência suas repercussões sobre os procedimentos e resultados da atividade.

\subsection{OBJETIVOS ESPECÍFICOS}

2.2.1. Apreender o modo como os usuários percebem o processo de aconselhamento pós-teste em relação à escuta de suas preocupações e sentimentos decorrentes da comunicação do resultado positivo para o HIV.

2.2.2. Identificar o modo como os clientes interpretam o lugar que ocupam como sujeitos no processo de revelação da soropositividade.

2.2.3. Apreender o enfoque dado no aconselhamento quanto às informações referentes à prevenção das DST/Aids, ao tratamento da infecção pelo HIV e ao autocuidado.

2.2.4. Identificar quais os aspectos do aconselhamento sorológico preconizado pelo Programa Nacional de DST e Aids são abordados na comunicação do resultado positivo para o HIV. 


\section{MÉTODO}

\subsection{COLETA DE DADOS}

\subsubsection{Acerca do Trabalho de Campo}

Como já foi explicitado, o campo de pesquisa é o aconselhamento sorológico, espaço no qual se processa a comunicação do resultado do teste anti-HIV positivo, objeto do presente estudo.

Antes de iniciar propriamente a pesquisa de campo, o projeto de pesquisa foi apresentado às unidades de DST/Aids, não apenas as envolvidas, mas toda a rede, composta na ocasião por 19 serviços (atualmente, existem 22, sendo: 9 CTA, 10 SAE e 3 CR). A Área Técnica de DST/Aids da cidade de São Paulo possui um setor de pesquisa organizado que realiza reuniões sistemáticas, com periodicidade mensal, com representantes de todos os serviços. Nesse espaço de interlocução, as unidades eleitas como locus da pesquisa foram informadas sobre seus objetivos e procedimentos, e sobre o início subseqüente da coleta de dados. Aos representantes de cada um dos CTA envolvidos (interlocutores de pesquisa) foi solicitado o agendamento de um encontro com os aconselhadores daqueles serviços, o que foi feito nos próximos dias. A opção por estes dois CTA foi pautada pelos dados de produtividade dos próprios serviços, isto é, por serem os que mais realizam testes sorológicos anti-HIV dentre todos, e pelas suas localizações. Um fica no "coração" da cidade, na região central, e o outro no coração da zona sul (Mapa de Serviços de DST/Aids, no Anexo 1). Ambos estão sediados em um local de grande circulação de pessoas.

O número de atendimento realizado mensalmente varia entre os dois serviços, bem como a taxa de soropositividade. Em um CTA a média mensal dos testes antiHIV realizados no ano de 2004 foi de 699,6 testes, com taxa de soropositividade de $4,34 \%$, enquanto que no outro, a média mensal foi de 521,4 testes, com taxa de soropositividade de 2,64\%. Esses dados foram fornecidos pelos setores de vigilância epidemiológica dos respectivos serviços.

A reunião com os aconselhadores nesses CTA realizou-se com a presença da 
maioria deles, dos gerentes e do interlocutor de pesquisa de cada unidade. Os materiais necessários à divulgação e realização do trabalho foram disponibilizados: um exemplar do projeto de pesquisa, algumas cópias do Termo de Consentimento Livre e Esclarecido (Anexo 2), cartazes para afixar em locais de circulação na unidade (Anexo 4), além de cartões-convite aos voluntários (Anexo 5) contendo as informações sobre a pesquisa para serem fornecidos aos clientes.

Era esperado que este tipo de pesquisa provocasse certo desconforto e, eventualmente, mal-estar entre os profissionais envolvidos, uma vez que as informações a serem obtidas decorrem diretamente do trabalho desenvolvido por eles no atendimento aos sujeitos pesquisados. Assim, a pesquisadora discutiu com as equipes a respeito de como captar os voluntários, de maneira que se alterasse o menos possível a rotina de trabalho de cada instituição. Em um dos CTA, uma das aconselhadoras expressou claramente sua sensação de sentir-se exposta ao ser feita a investigação a respeito de uma atividade da qual ela participa. Ao contrário, no outro CTA, uma das participantes do processo de aconselhamento referiu ser de muito interesse para o serviço os resultados da pesquisa, pois essa era a oportunidade de saber como o trabalho desenvolvido pela equipe é percebido pelas pessoas atendidas.

Para operacionalizar a captação de voluntários, combinou-se que ambas as equipes fariam a divulgação da pesquisa para os usuários ao final do aconselhamento, momento em que o cartão-convite também seria oferecido.

Uma das equipes preferiu abrir um agendamento das entrevistas com horários pré-fixados com a pesquisadora, e essa seria avisada tão logo fosse incluído alguém. Funcionários do setor administrativo ficaram encarregados desta tarefa, da mesma forma como faziam com o agendamento rotineiro da unidade.

A outra equipe preferiu orientar o cliente, interessado em participar do estudo, a fazer ele mesmo o contato com a pesquisadora para marcar o horário da entrevista.

Em um dos CTA, dois meses e meio depois dessa reunião com a equipe, o primeiro voluntário aceitou o convite para participar da pesquisa. Durante os próximos seis meses, havia pelo menos uma entrevista marcada por mês, como pode ser observado no quadro 1, mais à frente. No outro CTA, após quatro meses um voluntário ligou, marcou a entrevista, mas a cancelou antes da sua realização. A 
seguir, um segundo voluntário ligou, marcou a entrevista e compareceu. Isso ocorreu após ter transcorrido seis meses da reunião com os aconselhadores.

Durante todo o período, contatos eram feitos entre a pesquisadora e as gerentes dos dois CTA, com o intuito de fortalecer o vínculo e manter a coleta de dados em andamento. No decorrer do período em que, em uma unidade o trabalho de captação de voluntários estava adiantado e na outra, apenas iniciando, a pesquisadora propôs nessa última, a abertura de uma agenda a exemplo do trabalho já realizado no outro CTA.

Além disso, a pesquisadora dirigia-se para aquele CTA nos dias disponibilizados, independentemente de haver voluntários agendados, em uma espécie de "plantão". Essa medida aproximou a pesquisa da instituição e foi possível tomar depoimentos logo após o aconselhamento pós-teste, quando o voluntário estava disponível; ou agendar para outro dia, conforme ele desejasse.

Três depoimentos foram tomados antes da revelação da segunda sorologia (exame confirmatório). A entrevista de pesquisa de Cássio foi realizada no mesmo dia do seu primeiro aconselhamento, a de Paulo nove dias depois, e a de Bruno, após três dias. Observou-se, nesses casos, que os clientes conseguiram expressar suas percepções sobre o modo como lhes foi comunicado o resultado, porém, dois deles - Cássio e Paulo - , tinham a esperança de que o resultado da segunda amostra de sangue fosse negativo, enquanto que o outro não. Um desses entrevistados (Paulo) retornou para a segunda entrevista e, assim, suas informações a respeito das duas revelações de resultado puderam ser obtidas. Outro entrevistado (Cássio), no entanto, avisou que não poderia comparecer. Bruno não quis deixar a segunda entrevista marcada porque ia viajar.

Outros três entrevistados foram ouvidos no mesmo dia da segunda comunicação da sorologia e, nos três casos, esse tempo não pareceu interferir na maneira pela qual eles formularam seus depoimentos. Assim, a estratégia de estar presente no CTA, em determinados dias, permitiu que as entrevistas pudessem ser concluídas ali.

A colocação de cartazes, convidando as pessoas para serem participantes do estudo, havia sido uma forma de captação viável e rápida no estudo realizado por 
OLIVEIRA (2003). No entanto, no presente estudo, cartazes foram colocados nos dois CTA e nenhum voluntário se apresentou por meio desta forma de divulgação. Este não foi, portanto, um instrumento de recrutamento de participantes satisfatório para a pesquisa.

\subsubsection{O Encontro com os Voluntários - As Entrevistas}

Para coletar os dados, utilizou-se a entrevista como técnica, definida como “Conversa a dois, feita por iniciativa do entrevistador, destinada a fornecer informações pertinentes para um objeto de pesquisa, e centrada (pelo entrevistador) em temas igualmente pertinentes com vistas a este objetivo" (KAHN e CANNEL 1962, p. 52 citados por MINAYO 1994, p. 108). No caso do presente estudo, para que o objetivo de que a conversa circulasse em torno do aconselhamento pós-teste ou o momento da comunicação do resultado soropositivo —, foi eleita a frase: “Conte-me, como foi a comunicação do resultado positivo para você aqui no CTA”, como introdutória do diálogo, e utilizada em todas as entrevistas.

A partir dessa indicação, pretendeu-se criar um espaço livre para o sujeito construir a narrativa à sua própria maneira. As informações essenciais a serem coletadas giraram em torno dos objetivos da pesquisa, que se basearam nos objetivos a serem alcançados pelo aconselhamento sorológico, conforme sugerido pelos Programas Oficiais de DST e Aids, já mencionados no capítulo introdutório. Caso isso não ocorresse, o entrevistador - neste caso, a própria pesquisadora introduzia questões que favorecessem a obtenção das informações necessárias. Não houve um roteiro de entrevista estabelecido previamente, porém haviam temas a serem abordados (Anexo 6), quando os sujeitos não os mencionavam espontaneamente. Não se procurou impedir que outros conteúdos colocados pelos sujeitos permeassem a conversa, de forma a privilegiar a história e a expressão de cada um.

Trata-se de uma modalidade de entrevista aberta, na qual o entrevistado pode falar livremente sobre o assunto em foco (MINAYO 1994). A instrução inicial é sugestiva do procedimento denominado por pesquisadores do campo das ciências sociais como: depoimento pessoal, história de vida tópica ou história oral 
(QUEIROZ 1991; MINAYO 1994). Nesse tipo de procedimento metodológico, o sujeito é convidado a falar a respeito de uma determinada faixa de tempo vivido, que o remeterá a um acontecimento ocorrido naquele momento da vida dele e é o objeto da investigação.

A utilização da entrevista, tal como descrita, foi uma tentativa de trazer à tona de forma oral, o enredo deste momento repleto de significações, dificilmente acessíveis e compartilháveis, e que, certamente, têm interferências subjetivas na narrativa do entrevistado, decorrentes de sua memória, de sua vivência da situação e da abordagem do entrevistador. Portanto, era esperado que a forma como o sujeito organizasse a seqüência e conteúdo de seu relato seguiria o rumo que ele preferisse, podendo ter idas e vindas, paradas, repetições, além de lacunas marcadas por falhas de memória, motivação e/ou percepção, ou mesmo pela própria entrevista. E foi o que ocorreu, como se poderá observar mais adiante. Esses aspectos foram importantes para revelar sentimentos ou representações mentais de cada um dos sujeitos ao vivenciar a experiência de revelação do seu diagnóstico HIV positivo, e de como ele percebeu o aconselhamento ao qual se submeteu em seu passado recente. A evocação das lembranças estava sempre subordinada ao próprio funcionamento mental dos sujeitos envolvidos. Por meio de suas próprias palavras, eles foram estabelecendo associações irrompendo determinadas lembranças, camuflando outras. O papel da pesquisadora foi também determinante da continuidade (ou não) nos temas relacionados ao contexto da revelação do diagnóstico, uma vez que, dependendo da condição singular de cada entrevistado, o caminho trilhado pelas narrativas ia se diversificando e se afastando do foco central de interesse do presente estudo. A atitude de escuta e disponibilidade em um momento subseqüente ao aconselhamento foi favorável ao aparecimento de conteúdos psicológicos significativos para os clientes. Isso pode ter tido efeitos $a$ posteriori nos sujeitos, relacionados tanto à revelação do diagnóstico, quanto à oportunidade de terem mais um momento em que podiam falar de suas questões pessoais.

As entrevistas se desenrolaram de forma semelhante em termos da abordagem ao tema do aconselhamento de forma recorrente, ou seja: por diversas vezes se voltava à rememoração daquele instante face a face. O resultado dessa focalização, 
em alguns casos, foi a produção de informações repetitivas, mas permitiu também a emergência de novas lembranças. A forma da conversa era sempre descontraída, de forma a permitir a livre expressão dos entrevistados e o trabalho só era encerrado quando o entrevistado dizia que não havia mais informações a acrescentar. A duração das entrevistas variou de 45 minutos a uma hora e 15 minutos.

De acordo com MINAYO (1994), o tipo de informação perseguido por meio desta técnica de entrevista referir-se-á:

a) à descrição do caso individual (como foi, para cada sujeito, a comunicação do resultado do teste);

b) à compreensão das especificidades culturais mais profundas dos grupos (o que subjaz às marcas específicas dos sujeitos que passam por esta experiência de vida, ou as especificidades das práticas de comunicação de resultados nos serviços estudados); e

c) à comparabilidade dos casos e dos CTA envolvidos (dos processos de comunicação dos resultados dos envolvidos no presente estudo), guardadas as devidas proporções pelo número de casos estudados e pela natureza qualitativa da investigação.

As entrevistas foram gravadas a fim de “... manter ao máximo as próprias expressões dos informantes e a sua maneira de encadear os fatos...” (QUEIROZ 1991, p.60-1). As intervenções da pesquisadora ocorreram, como já foi dito, quando necessárias, para pedir maior precisão em algum detalhe e orientando a interlocução para os objetivos do estudo. O entrevistado podia voltar a falar de algo que já havia falado, sem ser impedido, pois isso poderia ser revelador de conteúdos e preocupações mais prementes para cada um deles.

Ao final do primeiro encontro com o voluntário, era proposta uma segunda entrevista, deixando claro sua livre escolha para participar ou não. Alguns voluntários não compareceram à segunda entrevista, sendo que dois deles foram ao CTA antes do horário marcado para justificar a ausência. Esses sujeitos se propuseram a marcar um novo horário, mas isso não ocorreu. Houve desistências também na primeira entrevista ( 8 pessoas), havendo duas mulheres nesse grupo. 
Após o término e escuta dos depoimentos, foram feitas as transcrições para a escrita em papel. Uma parte de uma das entrevistas foi excluída por problemas técnicos de gravação.

Além da entrevista, foram colhidas informações de caráter epidemiológico e social por meio do "Formulário de Atendimento dos CTA" (Anexo 3), com os devidos consentimentos dos voluntários e das gerentes das instituições. Os dados extraídos sobre os participantes do estudo permitem conhecer melhor as condições determinantes de sua vulnerabilidade à epidemia de aids. Algumas dessas informações estão expostas no Quadro 2, mais à frente, no capítulo de resultados.

\subsubsection{Descrição dos Serviços e da População de Estudo}

Um dos CTA envolvidos no estudo foi o primeiro a ser criado em São Paulo. Por um período de tempo foi designado como "COAS treinador" pelo Ministério da Saúde, tendo sido responsável, dentre outros, pelo treinamento da equipe do outro CTA envolvido, quando do início de seu funcionamento. O papel como treinador, deste CTA, não é mais desempenhado desde 1998, com a descentralização da gestão do nível federal para o nível municipal.

As instalações físicas dos dois serviços são distintas. Um dos CTA está instalado em um conjunto de escritórios em um edifício, ocupando dois pavimentos. O outro CTA está instalado em uma casa com dois pavimentos, com uma edícula ao fundo onde estão localizadas as salas de atendimento individual. Em ambos, existe uma divisão do espaço físico de forma a organizar as ações de saúde ali desenvolvidas em setores: recepção e entrega de insumos de prevenção, orientações coletivas pré-teste, coleta de sangue, orientações individuais pré e pós-teste, reuniões da equipe, arquivo de prontuários, funções administrativas e gerência.

Os dois CTA possuem características semelhantes quanto ao horário de funcionamento (das 7 às 19 horas, de segunda à sexta-feira) e quanto à composição da equipe. Todos os aconselhadores são do sexo feminino e pertencem às categorias profissionais: médicas, enfermeiras, assistentes sociais, psicólogas e educadoras de saúde pública. Há profissionais que fazem parte de cada uma das equipes desde o início do funcionamento da unidade. Outros foram transferidos de outras unidades 
em função da movimentação de pessoal decorrente das mudanças periódicas de governo, e em função dos próprios interesses pessoais e profissionais. Essa é uma informação importante, pois o trabalho do aconselhador é específico dos CTA, não se encontrando esta função em unidades de saúde não especializadas em DST/Aids. Assim, quando opta por trabalhar em um CTA, o profissional de saúde com nível universitário assume a função de "aconselhador".

No presente estudo, ao escolher a população usuária desses CTA da Cidade de São Paulo, pretendeu-se manter a fidelidade aos objetivos da pesquisa, que estão relacionados ao aconselhamento sorológico como prática preconizada pelo Ministério da Saúde para estes serviços, mas também, identificar a forma como cada um deles o adota, em função de seus recursos humanos e das características populacionais das regiões onde estão localizados.

$\mathrm{O}$ número de sujeitos de pesquisa não foi definido a priori. $\mathrm{O}$ estabelecimento do limite de voluntários se deu em função de critérios como: a dificuldade de captação de voluntários (referida do início deste capítulo) e a conseqüente demanda e extensão do tempo de coleta em quatro vezes o inicialmente previsto, a repetição dos conteúdos em um mesmo serviço, a qualidade dos dados obtidos a partir das entrevistas e a natureza qualitativa do estudo. Determinou-se, a certa altura do trabalho de campo, um mesmo número de pessoas para os dois CTA.

Foram critérios de inclusão na pesquisa: (i) ter 18 anos ou mais; (ii) ter resultado positivo para o HIV, obtido no Ensaio Imunoenzimático (Elisa) repetido duas vezes e confirmado pelo Ensaio de Imunofluorescência Indireta e/ou Western Blot (conforme o protocolo do CTA); (iii) ter participado do processo de revelação do diagnóstico da infecção pelo HIV nos CTA pesquisados; e (iv) ter assinado voluntariamente o Termo de Consentimento Livre e Esclarecido (Anexo 2). Nesse documento, consta a informação de que o sujeito poderia se excluir ou desistir de participar da pesquisa em qualquer momento, se assim o desejasse.

Ao todo, foram realizadas 20 entrevistas, com 14 sujeitos, todos eles do sexo masculino. Como pode ser observado no Quadro 1, a seguir, o intervalo entre o primeiro aconselhamento e a entrevista variou bastante em função do tempo que cada usuário levou para buscar o resultado. Pode ser observado que o intervalo entre a primeira e a segunda entrevista da pesquisa oscilou entre uma e duas semanas, de 
acordo com a conveniência do sujeito para realizá-la. Os espaços sombreados mostram as ausências dos sujeitos na segunda entrevista. O tempo despendido na coleta de dados foi de um ano (entre as datas da primeira e da última entrevista).

Quadro 1. Relação de voluntários, segundo ser o primeiro teste realizado no CTA, ter infecção recente, intervalo (dias) entre o primeiro aconselhamento e a entrevista da pesquisa, intervalo (dias) entre o segundo aconselhamento e a entrevista da pesquisa, mês e ano da primeira entrevista de pesquisa e intervalo (dias) entre a primeira e segunda entrevista.

\begin{tabular}{|c|c|c|c|c|c|c|}
\hline $\begin{array}{c}\text { Voluntário } \\
*\end{array}$ & $\begin{array}{c}1^{o} \\
\text { teste } \\
\text { no } \\
\text { CTA? }\end{array}$ & $\begin{array}{l}\text { Infecção } \\
\text { recente? }\end{array}$ & \begin{tabular}{|c|} 
Intervalo entre \\
$1^{\circ}$ \\
$\begin{array}{c}\text { aconselhamento } \\
\text { e entrevista } \\
\text { (dias) }\end{array}$ \\
\end{tabular} & \begin{tabular}{|c|} 
Intervalo entre \\
$2^{\mathbf{0}}$ \\
aconselhamento \\
e entrevista \\
(dias) \\
\end{tabular} & $\begin{array}{c}\text { Mês e ano } \\
\text { da } 1^{\mathrm{a}} \\
\text { entrevista }\end{array}$ & $\begin{array}{c}\begin{array}{c}\text { Intervalo } \\
\text { entre } 1^{\mathrm{a}} \mathbf{e} \\
2^{\mathrm{a}}\end{array} \\
\text { entrevista } \\
\text { (dias) } \\
\end{array}$ \\
\hline Silvio & Sim & Não & 15 & 3 & \multirow{2}{*}{$12 / 03$} & \\
\hline Milton & Sim & Não & 63 & 7 & & 14 \\
\hline Nei & Sim & Não & 60 & 7 & $01 / 04$ & \\
\hline Luis & Sim & Não & 21 & nenhum & \multirow{2}{*}{$03 / 04$} & 7 \\
\hline Jonas & Não & Sim & 50 & 33 & & 14 \\
\hline Evandro & Sim & Não & 30 & 9 & $05 / 04$ & 7 \\
\hline Juvenal & Não & Sim & 27 & 5 & \multirow{2}{*}{$06 / 04$} & 7 \\
\hline Arnaldo & Sim & Não & 19 & nenhum & & \\
\hline Pedro & Sim & Não & 49 & 5 & $07 / 04$ & \\
\hline Cássio & Sim & Não & nenhum & - & \multirow{2}{*}{$10 / 04$} & \\
\hline Mário & Não & Sim & 19 & nenhum & & \\
\hline Omar & Não & Sim & 120 & 11 & $11 / 04$ & \\
\hline Paulo & Sim & Não & 9 & 1 & \multirow{2}{*}{$12 / 04$} & 7 \\
\hline Bruno & Não & Sim & 3 & $* *$ & & \\
\hline
\end{tabular}

* Nomes fictícios

** Não fez o teste confirmatório. 


\subsubsection{Considerações Éticas}

A inclusão dos sujeitos no presente estudo se baseou nos preceitos da ética em pesquisa com seres humanos, abaixo descritos e conforme termo de consentimento livre e esclarecido assinado pelos voluntários.

Consentimento: "A participação do pesquisado deve ser livre, voluntária e consciente" (FORTES 1998, p. 111). Após o esclarecimento sobre os objetivos, metodologia, beneficência e riscos da pesquisa ao sujeito, ele teve todo o poder sobre a sua decisão de participar ou não da pesquisa. Sua participação foi, portanto, voluntária. Em se tratando de usuários de serviços de saúde, foi explicitada a independência entre a não participação e a continuidade do atendimento, para que o pesquisado não se sentisse coagido a participar. É garantida a privacidade dos participantes.

Beneficência: Os benefícios da pesquisa não atingirão diretamente os indivíduos pesquisados, já que visam melhoria das condições de aconselhamento dos serviços nos quais são comunicados os resultados do teste positivo. Beneficiarão futuramente outros indivíduos pertencentes a grupos populacionais semelhantes aos primeiros. Entretanto, os sujeitos da pesquisa poderão ser beneficiados pela prevenção da reinfecção pelo HIV e pela conscientização da responsabilidade pessoal pela própria saúde. Por meio da entrevista, tiveram a oportunidade de atenção e escuta às suas emoções e sentimentos decorrentes da comunicação do seu resultado, possibilitando maior autoconhecimento e elaboração mental. Com isto, considera-se estar contribuindo para a diminuição da vulnerabilidade no nível individual dos envolvidos. Por ser uma pesquisa envolvendo aspectos psicológicos e comportamentais, havia danos e riscos não previsíveis, decorrentes da forma como o cliente lidou e/ou lida com a própria soropositividade e de como isto afetou e/ou afeta sua vida em suas relações pessoais, sociais e profissionais. Nesse caso, o ônus ou a maleficência puderam ser minimizados com oferecimento de atendimento psicológico a quem sentisse necessidade do mesmo. Isso pôde ser garantido pela própria rede pública e pelos serviços municipais especializados em aids, quando foi o caso.

Eqüidade e Justiça: Considera-se que estes critérios foram respeitados nessa 
pesquisa, uma vez que os pesquisados pertencem a uma população vulnerável que teve acesso à pesquisa de forma igualitária (a escolha dos mesmos se deu mediante candidatura voluntária nos serviços freqüentados, como já foi descrito). Pretende-se estender os resultados aos seus iguais, podendo intervir no curso da epidemia, considerando-se este estudo de "Relevância social (...) não perdendo o sentido de sua destinação sócio-humanitária”. (CONSELHO NACIONAL DE SAÚDE 1996, p. 7)

Divulgação dos resultados: as conclusões do estudo estarão acessíveis aos pesquisados e aos serviços municipais envolvidos, sendo garantido o anonimato das informações.

\subsection{ANÁLISE DAS ENTREVISTAS}

Cada entrevista foi transcrita de maneira literal. Correções no modo de falar dos entrevistados foram feitas somente quando necessárias para a compreensão do conteúdo, mantendo-se alguns erros de concordância gramatical e alguns vícios de linguagem. Gírias foram colocadas no formato itálico ou entre aspas, conforme o contexto.

Uma entrevista é considerada como uma unidade de significação dentro do corpus, definido como o “... conjunto dos documentos tidos em conta para serem submetidos aos procedimentos analíticos" (BARDIN 1995, p. 96). Constitui a totalidade dos discursos produzidos nas entrevistas. O verbete "discurso" está sendo tomado, aqui, como a produção de um locutor em uma situação de interlocução, tal como em BLANCHET (1992, p. 2, nota de rodapé).

Segundo CALDEIRA (1984), a análise de entrevistas deve ser precedida de um exame cuidadoso de cada uma delas, tomando-a como um todo, no intuito de compreender sua lógica, aspectos ambíguos, contraditórios e inconscientes. "Só depois que o pesquisador domina o sentido do todo e de cada contexto interno é que pode comparar partes de uma entrevista com partes de outra" (p.145). Analisando dessa maneira, pretendeu-se capturar cada história de revelação do diagnóstico da infecção pelo HIV das pessoas entrevistadas.

Para a sistematização e organização dos dados, utilizou-se a técnica de análise de conteúdo, inicialmente efetuando-se a leitura de cada entrevista e a identificação 
de como o discurso se organizou em torno da hipótese pesquisada. Foram se fazendo recortes nos relatos, norteados pelas categorias analíticas construídas a partir dos objetivos, que são centrais para esta análise de forma a permitir a visualização e comparação dos dados. Essa pode ser considerada como uma primeira forma de análise do material coletado, visando uma organização do corpus. Trata-se de uma análise descritiva de aspectos essenciais que devem constar, por definição, no aconselhamento sorológico.

A coerência singular de cada entrevista é perseguida. No entanto, a técnica de análise de conteúdo propõe que se agrupe mais de uma fala em torno de temas centrais de análise, visando à conformação de um corpo mais articulado.

De acordo com BLANCHET (1992), “... uma análise de conteúdo deve poder dar conta da quase totalidade do corpus (princípio de extensão), ser fiel (o que é verificável pela multi-codificação) e auto-suficiente (sem retorno necessário ao corpus)" (p. 6). Com esse procedimento, efetuaram-se recortes das entrevistas, relevantes para evidenciar os aspectos investigados. Esses recortes são extensos, algumas vezes, a fim de não comprometer o sentido dos relatos. Entende-se que com esta medida a ausência de todos os depoimentos não trará prejuízo à compreensão do objeto de estudo. Essa opção destina-se a garantir o sigilo das informações, tanto em relação aos sujeitos, quanto em relação aos serviços.

Por meio de um segundo procedimento, foi realizada a análise do processo em si de aconselhamento. Isso possibilitou a percepção da dinâmica do momento em que o aconselhamento pós-teste foi praticado, tal como a apreensão de uma cena. Essa forma de análise pretendeu ser reveladora de processos psicológicos que se operaram naquele instante face a face entre o sujeito de pesquisa e o profissional de saúde. O suporte teórico escolhido para essa leitura e análise é a teoria psicanalítica, especialmente no que concerne aos aspectos conceituais já desenvolvidos no capítulo teórico, cuja base é a escuta dos conteúdos latentes dos discursos manifestos e das associações que encadeiam as idéias e pensamentos do sujeito para, a partir daí, buscar seu significado. A atitude clínica de escuta e de interpretação fornecida pela psicanálise é a ferramenta metodológica que possibilita este segundo tipo de análise.

TURATO (2003) denomina esta metodologia de "clínico-qualitativa" e a 
define como estudo e construção de limites epistemológicos em um campo. Como instrumento de trabalho, são utilizados técnicas e procedimentos que permitam a compreensão das relações de sentidos e significados de determinados fenômenos humanos que estão referidos dentro desse campo. Por esse método a atitude de acolhida das angústias dos sujeitos em estudo pode ser favorecida, valorizando-se os aspectos emocionais mobilizados na relação com esses sujeitos. É um método baseado na psicanálise, na fenomenologia e nos métodos qualitativos das ciências humanas e que serve como recurso na área da saúde (p. 242).

Segundo esse autor, a técnica de análise interpretativa propõe que se estabeleçam, a priori, grades de leitura que permitirão evidenciar significados escondidos de um texto ou fenômeno, conhecendo-se dessa maneira os conteúdos latentes (TURATO 2003, p. 440).

Foram analisadas histórias pessoais de experiências ocorridas em contextos singulares, uma vez que os aconselhamentos pós-teste relatados referem-se a situações diversas envolvendo aconselhadores e clientes, mas que possuem um cenário comum que confere um aspecto de similaridade - no interior da diferença — ao material de análise.

O que serviu de guia à leitura das entrevistas e organização dos resultados foi $\mathrm{o}$ fato de os serviços seguirem o mesmo protocolo e as mesmas diretrizes para o aconselhamento. A utilização dos conceitos extraídos da teoria de WINNICOTT (1951, 1954-5, 1955-6, 1967a, 1967b, 1968, 1975, 1984, 2001) sobre os quais foi estruturado o presente estudo, serviu como matriz de análise, cuja construção provém da interação entre as hipóteses iniciais do trabalho e o corpus (BLANCHET 1992), constantemente vistos, revistos e articulados. A interação constante possibilitou operar como conceitos utilizados fora de seu campo original.

O capítulo a seguir mostra esses dois modos complementares de análise, na forma de resultados da investigação. 


\section{RESULTADOS}

\subsection{APRESENTAÇÃO DOS SUJEITOS DE PESQUISA}

Será feita uma breve apresentação de dados sociais e epidemiológicos extraídos dos "Formulários de Atendimento dos CTA" (Anexo 3) referentes aos sujeitos entrevistados. Essas informações encontram-se dispostas no quadro 2, abaixo, e também em um resumo de cada um dos sujeitos a seguir. Relata-se, assim, um pouco da história de vulnerabilidade à infecção de cada um, tomando-se, ainda, para isso certas informações das entrevistas. A exposição obedecerá a ordem de apresentação do quadro para facilitar a visualização e o acompanhamento.

Quadro 2. Relação de voluntários, segundo faixa etária, categoria de exposição à infecção, escolaridade (em anos de estudos concluídos), situação atual de trabalho, ter atualmente parceria fixa e número de parceiros no último ano.

\begin{tabular}{|c|c|c|c|c|c|c|}
\hline Voluntário & $\begin{array}{l}\text { Faixa } \\
\text { etária } \\
\text { (anos) }\end{array}$ & $\begin{array}{c}\text { Categoria de } \\
\text { exposição }\end{array}$ & $\begin{array}{l}\text { Escolaridade } \\
\text { (anos) }\end{array}$ & $\begin{array}{c}\text { Situação } \\
\text { atual de } \\
\text { trabalho }\end{array}$ & $\begin{array}{c}\text { Parceria } \\
\text { atual } \\
\text { fixa }\end{array}$ & $\begin{array}{c}\text { Número de } \\
\text { parceiros } \\
\text { no último } \\
\text { ano }\end{array}$ \\
\hline Bruno & \multirow{6}{*}{20 a 29} & Homossexual & 4 a 7 & Autônomo & Não & $\begin{array}{c}\text { Mais de } \\
100\end{array}$ \\
\hline Jonas & & Homossexual & 12 ou mais & $\begin{array}{l}\text { Trabalho } \\
\text { informal }\end{array}$ & Sim & 8 a 10 \\
\hline Arnaldo & & Inconclusiva & 8 a 11 & Desemprego & Não & Nenhum \\
\hline $\mathrm{Nei}$ & & Heterossexual & 8 a 11 & $\begin{array}{l}\text { Trabalho } \\
\text { formal }\end{array}$ & Não & 1 \\
\hline Milton & & Homossexual & 12 ou mais & $\begin{array}{l}\text { Trabalho } \\
\text { esporádico }\end{array}$ & Sim & 11 a 50 \\
\hline Omar & & Homossexual & 12 ou mais & $\begin{array}{l}\text { Trabalho } \\
\text { formal }\end{array}$ & Sim & 2 a 4 \\
\hline Evandro & \multirow{4}{*}{30 a 39} & Homossexual & 8 a 11 & Desemprego & Sim & 5 a 10 \\
\hline Pedro & & Homossexual & 8 a 11 & Desemprego & Sim & 1 \\
\hline Juvenal & & Homossexual & 8 a 11 & $\begin{array}{l}\text { Trabalho } \\
\text { formal }\end{array}$ & Não & 2 a 4 \\
\hline Mário & & Homossexual & 4 a 7 & Autônomo & Sim & 2 a 4 \\
\hline Paulo & \multirow{3}{*}{40 a 49} & Homossexual & 8 a 11 & $\begin{array}{c}\text { Trabalho } \\
\text { formal }\end{array}$ & Não & 11 a 50 \\
\hline Luís & & Homossexual & 4 a 7 & $\begin{array}{c}\text { Trabalho } \\
\text { formal }\end{array}$ & Não & 5 a 10 \\
\hline Sílvio & & Heterossexual & 1 a 3 & Desemprego & Sim & 2 a 4 \\
\hline Cássio & 60 a 69 & Homossexual & 4 a 7 & $\begin{array}{l}\text { Aposentado } \\
\text { Trabalho } \\
\text { esporádico } \\
\end{array}$ & Sim & 2 a 4 \\
\hline
\end{tabular}




\section{Bruno}

Bruno tinha 21 anos no dia da entrevista da pesquisa e é o mais jovem dos entrevistados. Veio ao CTA acompanhado por amigos e não era a primeira vez que realizava o teste anti-HIV, tendo realizado dois testes, anteriormente, cujos resultados foram negativos. Não tem parceiro fixo e só pratica sexo com homens. Trabalha durante o dia como cabeleireiro e, à noite, como profissional do sexo (na rua). É travesti. Tem consciência do risco de contrair DST e refere fazer sexo seguro em todas as relações sexuais profissionais, incentivando essa prática aos seus amigos e familiares. De acordo com Bruno, sua infecção pelo HIV foi decorrente de uma relação afetiva na qual não fez uso de preservativo por estar sob efeito de bebida alcoólica. O resultado do exame "detuned" mostra que sua infecção é recente, razão pela qual ele afirma saber quando, onde e através de quem adquiriu o vírus. Refere ter estabelecido uma boa relação com a aconselhadora que o recebeu, tendo a intenção de retornar outras vezes para conversar.

\section{Jonas}

Não era a primeira vez que Jonas fazia o teste. Refere na entrevista que sabe com qual parceiro contraiu o vírus. É homossexual e tem parceiro fixo, embora tenha também relações sexuais eventuais com outras pessoas. Tem intenção de continuar fazendo prevenção, apesar de reconhecer que não usa preservativos em seu relacionamento estável e na prática sexual oral (porque não gosta). Considera que houve um descuido que ocasionou a infecção, uma vez que conhecia e fazia uso das formas de proteção nas relações sexuais. Infectou-se em uma relação com parceiro eventual. Tem trabalho remunerado informal.

\section{Arnaldo}

Este entrevistado refere estar impactado com o resultado positivo, o qual não esperava. Essa informação, porém, mescla-se à sua dificuldade de enfrentamento de questões da realidade (incluindo este resultado positivo), apresentando tendências evitativas em relação a elas. $\mathrm{O}$ mesmo se aplica à forma pela qual se infectou. Os dados de sua ficha revelam que tentou suicídio por duas vezes quando adolescente e que fez psicoterapia. Refere ter tido um irmão gêmeo (falecido aos dez anos) que não 
conheceu, pois cada um morava com um familiar diferente. Sua família mora em Minas Gerais e Arnaldo relata que não tem condições de compartilhar o seu estado soropositivo com familiares, por ter receio de viver situações de preconceito e conseqüente rejeição. Identificou-se com a escolha sexual heterossexual, embora em um dos aconselhamentos esteja apontada a categoria de exposição homossexual. Em um dos aconselhamentos, afirma que contraiu o HIV por meio de acidente doméstico com um amigo que soube depois (com tesoura de cortar cabelo), mantendo essa versão, na entrevista da pesquisa. Reporta não ter parceria fixa e usar preservativo em todas as relações com parceiros eventuais. Está desempregado. Arnaldo encontrase sem apoio social no momento da entrevista, e refere sentir-se perdido.

$\mathrm{Nei}$

Nei é solteiro e mora com um tio. Possui emprego fixo e tem a intenção de compartilhar a notícia com seu chefe, quando tiver oportunidade. Apresenta escolha sexual heterossexual e não sabe em qual relacionamento contraiu o vírus. Não foi a primeira vez que fez o teste anti-HIV no CTA. Adquiriu sífilis dois anos antes e se tratou em outro serviço de saúde. No último ano, teve uma única parceira e refere não ter usado preservativo com ela por não lhe atribuir risco. Usava preservativo ocasionalmente com parceiro fixo, mas não no sexo oral. Afirma que passará a fazer prevenção sistematicamente, pois não quer se re-infectar nem infectar outras pessoas. Demonstra uma atitude positiva com relação à vida, mesmo depois de receber o resultado positivo para o HIV. Refere, na entrevista, que pretende se engajar em trabalho voluntário relacionado à aids, aderindo ao que uma pessoa de sua família já desenvolve com crianças.

\section{Milton}

Milton tem curso superior completo pela Universidade de São Paulo e não tem emprego fixo. Realiza trabalhos remunerados de forma informal e esporádica. Não tinha interesse em fazer o teste, mas foi ao CTA para acompanhar amigos, sem se preocupar muito com o exame. Sentiu-se bem com o apoio que esses amigos lhe deram após o resultado. Milton só se relaciona sexualmente com homens. Até a realização do exame, usava preservativos às vezes, tanto com parceiro fixo como com parceiros eventuais. Este entrevistado tem um relacionamento estável, atualmente, com 
parceiro que tem sorologia negativa, segundo ele. Milton já compartilhou o seu resultado positivo com o parceiro, mas não pode fazê-lo com sua família, pois considera que seus pais não entenderiam e suas irmãs não aceitam ainda a sua homossexualidade. Relata que não usava preservativo antes, desde a adolescência, e tinha práticas sexuais de alto risco de contrair DST, considerando o resultado positivo a conseqüência disso.

\section{Omar}

Omar possui curso superior completo e trabalha com carteira assinada. Ele demorou vários meses para buscar o resultado do primeiro teste que fez. Sua escolha sexual é homossexual. Tem parceiro fixo que é portador do HIV. É solteiro, e tem parceiros eventuais com os quais usa preservativo sempre que há penetração. Sua infecção pelo HIV é recente, mas não há informação a respeito de através de qual relacionamento a adquiriu. Aceitou participar da pesquisa relativa ao teste "Detuned", que inclui o tratamento da infecção pelo HIV. Omar demonstra ter consciência do risco, mas encontra-se com dificuldades em relação ao resultado, desde o momento em que ele foi comunicado. Isso pode dificultar sua disposição para colocar em prática as medidas de prevenção.

\section{Evandro}

Evandro estava desempregado e morava com a mãe. Este entrevistado decidiu, recentemente, abandonar as práticas sexuais homossexuais que sempre foram sua opção. No passado, fazia programas sexuais em bares e cinemas pornôs no centro da cidade, sem usar preservativo. Fez teste anti-HIV para doar sangue há nove anos na Santa Casa, cujo resultado positivo recusou-se a aceitar como verdadeiro. Decidiu fazer esse novo exame agora, pois arrumou uma namorada, com a qual pretende se casar. Entrou para uma igreja evangélica e está convencido de que poderá ter o exame negativado com a ajuda da religião. Refere ter tido relação sexual com a namorada, mas sem penetração.

\section{Pedro}

Esse entrevistado teve um parceiro fixo por sete anos que faleceu de complicações decorrentes da aids dois meses antes da entrevista da pesquisa. Por 
essa razão, Pedro veio fazer o seu exame. Durante o período em que estiveram juntos, usaram preservativo às vezes. Eles tinham negociado não usar. Pedro refere que praticava sexo com outros parceiros ocasionalmente e, com esses, sempre usava preservativos. Nunca contraiu DST e sua prática sexual sempre foi com homens. Refere que depois de certo tempo que estava morando com seu parceiro, decidiram fazer o teste e, ambos deram negativo. Depois disso, nunca mais usaram preservativo, nem repetiram o teste sorológico. Pedro sempre achou que seu parceiro tinha outros relacionamentos, mas esses eram negados por ele. Era sustentado pelo parceiro e, após sua morte, continuou morando no apartamento com a tia do parceiro, mas ia se mudar em breve para a casa da irmã, por falta de condições financeiras para manter as despesas de moradia. Ia tentar conseguir uma pensão na justiça pelo tempo de união estável com seu parceiro.

\section{Juvenal}

Este entrevistado veio ao CTA, pois recebeu material de divulgação sobre o serviço. Havia realizado ali uma sorologia com resultado negativo um ano antes. Sua infecção é recente. É separado e não tem parceiro fixo no momento. No último ano, teve entre dois e quatro parceiros. Nesse mesmo período, teve também gonorréia. Refere que às vezes usava preservativo, às vezes não por confiar no parceiro. Pratica sexo com homens e com mulheres. Possui emprego fixo. Refere que é difícil a negociação do uso do preservativo nos relacionamentos sexuais, mas que ela é necessária. Tem intenção de ter práticas sexuais seguras de agora em diante.

\section{Mário}

Mário soube do CTA por meio de amigos e conhecidos. Realizou várias sorologias negativas antes desta que foi positiva. Sua escolha sexual é homossexual. Tem uma relação estável com parceiro que sabia ser soropositivo e não usou preservativo em todas as relações, alegando ter pena do parceiro. Estava com esse parceiro na hora da entrevista, mas este não participou dela. Às vezes tem relações sexuais com parceiro eventual, nas quais nem sempre usa preservativo. Refere que tinha consciência do risco de infecção, pois tem um irmão com aids que sempre o alertou para se prevenir. Mora com este irmão e com a mãe, que não sabe ainda que os filhos estão infectados. Mário não tem intenção de contar o resultado para ela, 
pois, segundo ele, ela não iria entender.

\section{Paulo}

Paulo tem emprego em instituição governamental e mora só. Veio ao CTA para acompanhar um amigo que também fez o teste. Refere que não esperava o resultado positivo, embora tivesse consciência do risco. Apresentava conhecimento sobre as formas de prevenção do HIV, mas admitiu que nem sempre as colocava em prática nas suas relações sexuais (exclusivamente com homens). Estabelece a distinção entre a prática sexual que envolve o afeto daquela que é apenas física (que chama de aventura), considerando que isso é o que implica na prática sexual protegida ou desprotegida. Refere ter usado preservativo na última relação sexual com parceiro eventual. Não tem parceiro fixo atualmente.

\section{Luís}

Soube da existência do CTA através de amigos. É operador de máquinas em uma pequena fábrica, já tendo sofrido acidente de trabalho mais de uma vez. Este entrevistado é homossexual e se traveste ocasionalmente. E, como travesti, praticava sexo em troca de pagamento "na noite" (nas ruas e em boates). Teve gonorréia há 15 anos. Tem consciência de risco de infecção. Refere que há seis anos faz uso do preservativo nas relações sexuais anais, mas não nas orais. Há oito meses, decidiu usar o preservativo também no sexo oral. Havia feito teste em banco de sangue, anteriormente, com resultado negativo. Vive só e não tem parentes próximos dele. Como já cuidou de pessoas com aids (quando ainda não havia TARV), teme não ter a companhia de pessoas, caso evolua para um estado de saúde debilitado e incapacitante.

\section{Sílvio}

Este entrevistado decidiu fazer a sorologia pela primeira vez ao passar na porta do CTA. É heterossexual, mas tem relacionamentos com homens esporadicamente. É casado e mantém relacionamentos extraconjugais com parceira estável e, ainda, com parceiras eventuais (de uma a duas por ano). Com as parceiras fixas não usa preservativo nunca, porque não tinha consciência do risco de infecção. Nas relações com parceiros eventuais (homens e mulheres) usa preservativo às vezes. Silvio 
tem filhos pequenos, e trouxe toda a família ao CTA para conhecer o estado sorológico.

\section{Cássio}

Cássio é o entrevistado com maior idade. É aposentado, mas trabalha informalmente como mensageiro. Casado, mora com mulher e um filho adulto. Informa que não tem mais relações sexuais com a esposa. Tem relações sexuais com homens jovens ocasionalmente, e se relaciona também com um parceiro fixo. Não fazia uso de preservativo sempre com esse parceiro porque ele não aceitava. Com parceiros eventuais usava às vezes, pois confiava no parceiro. Não se identifica com a homossexualidade, não tendo consciência do risco de infecção pela prática sexual anal não completada ou interrompida antes da ejaculação.

Após essa apresentação dos sujeitos, inicia-se a análise dos resultados, dando ênfase aos seus depoimentos como material privilegiado para a evidenciação dos aspectos a serem investigados em relação à prática de aconselhamento para a sorologia positiva. Na primeira parte (ítem 4.2), são os objetivos que norteiam a análise e, na segunda (ítem 4.3), são as interações aconselhador-cliente no processo de aconselhamento que serão analisadas.

\subsection{ANÁLISE DE CONTEÚDO DE ACORDO COM OS OBJETIVOS DA PESQUISA}

"Eu ia passando a procura de emprego. e... Procurando emprego, passei e vi uma placa escrito: 'gratuitamente', e eu falei, imaginei - 'o que será grátis?’. Hoje não tem nada grátis, né? Falei, - 'eu vou ter a curiosidade de olhar'. E olhei e quando eu li que eram esses exames gratuitos, né? Eu falei: - 'ah, já que eu tô à toa, procurando emprego, eu vou fazer' e... fiz. (...) Na hora que eu recebo o resultado, chamam eu num quartinho [sala de aconselhamento individual], né, e me dá aquela resposta, né, que o exame foi positivo. E aquilo ali eu nem me preocupei. (...) Então eu pensei até que... que o segundo resultado não deveria ser nada, quem sabe foi trocado isso aí. Eu ficava imaginando assim, né?. Mas só que veio o segundo resultado e continua dizendo que é positivo, né? E agora a gente fica na preocupação pra chegar e se jogar nas mãos dos médicos. Pra ver o que vai acontecer...”.

Sílvio, casado, 47 anos. 
Com essas palavras, Silvio começa a contar "Como foi dado o resultado positivo do seu teste de HIV naquele Centro de Testagem e Aconselhamento", a frase introdutória do diálogo. Sílvio é uma pessoa simples, cuja única preocupação era, até então, encontrar um trabalho com o qual pudesse sustentar sua família, que no seu caso é plural: duas famílias. Silvio mantém vínculo conjugal com duas mulheres, com as quais tem filhos. Emocionalmente, sente-se mais ligado e dependente de uma delas, a mais velha, com a qual reside e tem três filhos. Não deixa, contudo, de freqüentar a casa da outra a cada oito dias "... para levar coisas para o menino", como se expressa. Ainda mantém, ocasionalmente, relações sexuais com esta segunda mulher.

Como pode um aconselhador "adivinhar" ou ao menos suspeitar que aquela pessoa só esteja ali, recebendo aquele resultado, porque leu a faixa na porta da instituição que dizia que algo era "grátis"? Ou seja: como ele pode supor qual é a implicação subjetiva do cliente na própria revelação do resultado? Qual a ligação que o cliente estabelece com o exame que veio buscar o resultado? Ele tem noção de que pode ser soropositivo? Então, para cada pessoa que vem buscar o resultado, de que experiência emocional se trata?

Silvio entra no serviço de saúde pelo apelo de um oferecimento gratuito e sai com um "brinde" que nada tem de gratuito, já que começa a ter um preço a pagar dividido em prestações. De entrada, a primeira parcela é a da não compreensão. $O$ que é positivo? É positivo mesmo, ou foi trocado? Ele paga a primeira. Vem a segunda: como vai dizer às suas parceiras? Elas podem ir ao serviço para alguém contar a elas do que se trata? Essa última indagação, embora não esteja inscrita na vinheta inicial martela em sua cabeça, como será mostrado no curso do seu relato sobre a vivência da comunicação do resultado.

Para Sílvio, assim como para vários outros clientes, a implicação subjetiva de cada um que comparece ao serviço para fazer o teste anti-HIV varia, mas existe e não pode ser ignorada. Silvio, que chega de uma forma aparentemente casual, era movido por algo de si, de sua vida, que o fez tomar a decisão de fazer o teste.

A vida da maioria das pessoas entrevistadas era rotineira, até mesmo precária, "sob controle", sem grandes novidades e sobressaltos. Essa novidade é nova mesmo, 
inédita. Para alguns, não se assemelha a algo com o que já se lidou antes. O que pensar? Como agir? O que sentir? Dá para compreender? Como aconteceu? O que vai acontecer? Melhor “se jogar” nas mãos dos médicos, como Sílvio diz?

Com tantas coisas a interrogar, um espaço (e um tempo) primeiro precisa ser transposto: o espaço da revelação do diagnóstico. Se esse momento já era suposto como muito importante e pleno de significações para quem dele participa, agora, depois desse relato sobre a forma como alguém se adentra nele, sugere que muito se reflita a respeito. É o que se pretende realizar na elaboração dos resultados deste estudo. Principia-se, como já foi salientado, pela análise dos aspectos centrais da concepção do instrumento de aconselhamento.

Para melhor visualização das categorias construídas, o quadro abaixo expõe uma das maneiras pelas quais os resultados obtidos serão analisados, com as respectivas subdivisões:

Quadro 3. Categorias de análise construídas segundo os objetivos do estudo.

\begin{tabular}{|l|}
\hline \multicolumn{1}{|c|}{ Categorias de análise } \\
\hline Lugar ocupado pelo cliente em relação à escuta de suas preocupações e \\
sentimentos decorrentes da comunicação do resultado positivo para o \\
HIV. \\
Enfoque sobre as informações referentes à prevenção das DST/Aids, à \\
adesão à TARV e ao autocuidado \\
\hline Aspectos privilegiados na comunicação do resultado positivo \\
\hline$\bullet$ O preenchimento da ficha epidemiológica \\
\hline$\bullet$ O oferecimento de outro horário para conversar \\
\hline$\bullet$ A superação das dificuldades em compartilhar a notícia a outrem \\
\hline - Contar para o parceiro \\
\hline - Contar para outros familiares \\
\hline - Contar no trabalho \\
\hline
\end{tabular}


4.2.1. Lugar ocupado pelo cliente em relação à escuta de suas preocupações e sentimentos decorrentes da comunicação do resultado positivo para o HIV.

Essa categoria sintetiza dois objetivos específicos (2.2.1 e 2.2.2) que buscam investigar algo que está implícito na própria definição do aconselhamento sorológico: a escuta do sujeito e o lugar ocupado por ele como sujeito no seu processo de comunicação do diagnóstico. Os relatos dos clientes mostram que eles se dividem em dois grupos que correspondem grosseiramente às respostas sim ou não à questão referente à ocupação de um lugar central no próprio aconselhamento. Dois deles manifestam explicitamente sua opinião negativa em relação a essa questão, envolvida neste objetivo focalizado: não se sentiram centro da comunicação, nem se sentiram escutados quanto aos seus sentimentos e preocupações. Os outros doze consideram que este objetivo foi alcançado na comunicação do seu resultado positivo. Dessa maneira, a maior parte dos entrevistados sentiu que seus temores foram ouvidos e suportados, como se poderá observar em seus relatos abaixo. Todavia, observa-se, nas entrelinhas dessas narrativas, que muitos não conseguem explicitar a dificuldade de colocar questões aos aconselhadores por timidez (Silvio) ou por não se sentirem com direito de ocupar o tempo do profissional (Silvio e Paulo). Assim, pode-se perceber o êxito das aconselhadoras envolvidas nos atendimentos ao propiciarem a oportunidade de colocação das questões pessoais por cada um deles. No entanto, mesmo havendo uma boa atenção e intenção, algo parece faltar em certos contextos de aconselhamento, pois nem todos garantem a positividade anunciada pela maior parte dos sujeitos como se poderá observar.

Os relatos seguirão a seqüência cronológica das entrevistas, como foi mostrado no quadro 1 do capítulo do método, havendo, em muitos casos, a apresentação do conteúdo das preocupações específicas do sujeito, pois isso se mostrou relevante para a análise.

Por exemplo, no caso de Sílvio, suas preocupações estão voltadas ao “daqui para frente"; para as manifestações da doença; para algo que ele ainda não compreende. Seus sentimentos são de surpresa diante de algo tão inesperado, como se observou no trecho inicial. Ele se referiu ao bom trabalho das aconselhadoras.

Todavia, ao ser indagado pela pesquisadora se ele sentiu que tinha espaço, ou 
possibilidade de perguntar o que ele quisesse, diz que não, articulando essa negativa às diversas questões, tais como: tempo, gênero, timidez. Assim, ele responde o seguinte:

"Não. Não, sabe por quê? Porque quando a gente vai entrando assim na... A gente não tem experiência da coisa. Resultado: você fica em timidez. (...) Você entendeu? A gente vai e olha pra pessoa assim, tal. é... Será que eu... Como eu vou entrar no assunto pra perguntar...? Então a gente olha, às vezes, e não tem coragem. Chega e fica com vergonha. Entendeu? Então, com um determinado tempo é que eu posso entrar pra perguntar mais coisas que a gente tem que perguntar. Se abrir com a pessoa. A gente vai se abrindo com a pessoa com um determinado tempo. Primeira vez que vem, pra poder perguntar tudo, não pergunta. Ele nem acha a pergunta pra perguntar. Então ele pergunta algumas coisas, de dez ele vai perguntar duas. Entendeu?"

Ele fala que precisa de tempo. Como ficou explicitado na apresentação da teoria winnicottiana, a noção de espaço encontra-se intimamente ligada à de tempo. De forma que se pode perceber no relato de Sílvio que o espaço e o tempo aparecem como constitutivos de uma mesma estrutura narrativa.

Uma outra dimensão também se descortina no que ele diz: o fato de serem todas as aconselhadoras, mulheres. Cabe aqui a observação de que não há aconselhadores do sexo masculino em nenhum dos dois serviços pesquisados, mas é Sílvio que aponta seu desconforto com relação a esse fato:

"É, eu acho que o homem com a mulher, quando vem um homem tímido, ele vai ter vergonha de conversar com a mulher. Acho que, com um homem, ele não tem tanta vergonha, que vai ser homem com homem, né? Aí, vai, talvez, perguntar mais coisas, porque é homem. Agora com uma mulher, o homem, ele pode ter vergonha de uma mulher. Como tem homem que tem, né?"

E, indagado se com as perguntas que elas fazem, ele não sentiu que abriu um espaço para que ele também fizesse perguntas, ele disse:

"Não, é que a gente acha que o espaço é curto e se vai ficar fazendo perguntas vai demorar demais. Então fica tudo isso na cabeça da gente, né: 'não, se eu for fazer muitas perguntas eu vou estar atrapalhando elas'. Elas estão trabalhando, e pode ter outra pessoa lá esperando.” 
Uma análise possível desse conteúdo narrativo, é que Sílvio parece sentir-se estrangeiro. Em certo sentido, não tem a percepção de seu espaço na unidade de saúde, de seu direito àquele tempo e àquela atenção. Não se sente merecedor dele. Tem uma noção de assimetria na relação com esse outro, o aconselhador. A alteridade deste outro que o recebe lhe confere certa autoridade a ser respeitada, mas não compartilhada igualitariamente. Sílvio não quer invadir. E se contém. Tenta suportar consigo mesmo as próprias questões. Melhor guardá-las para si, melhor se calar. Já ocupou muito espaço dali e muito tempo daquele profissional.

Passando a outro entrevistado, Milton, que tentou racionalizar seu "abalo" diante da revelação diagnóstica. Foi possível a ele viabilizar este tipo de defesa pela acolhida e suporte que sentiu obter das aconselhadoras. À pergunta se sentiu que naquele momento da revelação foi colocado como centro do aconselhamento, responde com convicção:

"Com certeza! Com toda a certeza! Nossa, ela perguntou se eu tava bem, se eu queria conversar a respeito, sabe? Ela foi muito... Uma atenção muito grande... Bem atenciosa mesmo. Nossa, eu lembro que eu me admirei assim, porque ela deu um carinho muito grande. Coisa que na saúde pública, normalmente, não tem. Os aconselhadores foram maravilhosos".

Ele fala no plural, generalizando para as duas comunicações de resultados: do primeiro teste e do exame confirmatório. Em ambas, sentiu que teve espaço para colocar todas as suas preocupações.

"Dúvidas, preocupações... Tudo. Assim, eu senti carinho. Um trato, assim, muito carinhoso. E esse foi o legal da coisa. Eu não tenho do que reclamar, não tenho mesmo. Porque foi muito bom. Tanto que quando eu fui fazer o segundo exame, a aconselhadora queria tirar o sangue, só que ela não podia, porque ela não tinha o curso, alguma coisa assim".

Observa-se que boa parte do "tudo" referido não foi sequer tocada. De fato, naquele momento, o seu pensamento lógico (ao qual se refere mais abaixo) prevaleceu. Este entrevistado retorna para a segunda entrevista da pesquisa, menos protegido pelo mecanismo de racionalização, mostrando-se muito angustiado pela possibilidade de perder seu companheiro em decorrência do seu diagnóstico positivo. Assim, apesar da boa acolhida relatada, a questão da falta de tempo (referida 
anteriormente por Sílvio) também está colocada:

“Tive vontade de falar com alguém sobre o que está acontecendo, mas não houve tempo hábil, porque eu já estou indo ao SAE”.

A pesquisadora então pergunta: - Mas foi dito que você poderia voltar para conversar, se precisasse, não? Ele responde:

"Sim, foi dito, mas eu achei melhor não vir. Sempre trabalhei com lógica, não estou acostumado a lidar com emoção, com sentimento... (...) No momento, o que me preocupa é meu relacionamento com meu companheiro. Tenho medo de perder meu companheiro... Apesar de ele estar me apoiando, disse que vai lutar junto comigo. Mas eu me arrependo, porque eu teria mais liberdade, mais intimidade com ele se não tivesse o vírus. Eu vou levar em frente, levar a vida pra frente. Como eu falei: não adianta ficar deprimido".

A respeito do aconselhamento, ele afirma:

"Foi legal, apesar de no primeiro dia eu ter ficado melhor do que a aconselhadora. Mas ela foi muito carinhosa. (...) Não, eu não disse muita coisa, porque eu não estava abalado, eu estava bem".

A maneira como o resultado foi comunicado supriu as necessidades de Milton, tendo em vista que ele conseguiu manter suas defesas. Era esse seu desejo: não entrar em contato com sentimentos negativos (como o arrependimento) que provocam culpa e depressão. São sentimentos, que ele prefere evitar, pois não quer ficar deprimido. Para entrar em contato com seus sentimentos Milton precisa de mais tempo. E esse tempo teve que exceder o espaço do aconselhamento, como se verá mais à frente (ítem 4.3.1).

O aconselhamento de Nei, outro entrevistado, cumpriu o objetivo de tirar as dúvidas que teve até aquele momento da revelação do seu diagnóstico:

“Assim, dúvidas eu não tenho assim, mais dúvidas. As dúvidas que eu tinha elas já me esclareceram, assim. Eu tirei as dúvidas com elas..."

Outro entrevistado, Luís, refere ter tido espaço e tempo para se colocar em seu aconselhamento. Entretanto, suas preocupações estavam relacionadas ao futuro. Por morar sozinho, não teria ninguém para ajudá-lo quando precisasse. E, mesmo essa preocupação, surgiu depois, quando já estava em casa. 
"Oh, pra ser bem sincero... eu assim, não tive reação nenhuma, que eu até ri com ela, conversei, brinquei com ela aqui, entendeu... A recaída vem depois em casa. Porque eu penso que eu moro sozinho, eu penso que assim, dá uma recaída e não tem ninguém pra fazer um chá. (...) É isso a preocupação, mas sobre o problema da... Deste HIV, psicologicamente nem penso na minha cabeça. Só que uma coisa que eu quero viver e eu quero me tratar".

E, indagado sobre o momento da revelação, considera que pôde falar e ser ouvido:

"Falei com a médica [a aconselhadora]. (...) ... tranqüilo, ela já falou sobre a senhora, falou sobre esse lugar que ela me passou, que lá vai ter psicólogo. Então, uma vez por semana, se eu quiser conversar com uma psicóloga, eles oferece lá, já tem esse negócio, entendeu? Ela falou: 'hoje ela [referindo-se à pesquisadora], vai te explicar, é uma boa pra você', entendeu? (...) Porque onde que eu posso...? O serviço aqui, o básico é só isso. O medo é só isso: de depender dos outros, das outras pessoas, principalmente... Só isso que me preocupa".

Sobre o sentimento diante do diagnóstico positivo, de ter recebido o resultado, Luís diz:

"Não me abalou, não, nem me abala. Porque não sei se é porque eu já cuidei de pessoas até o último momento, né?"

Nota-se na fala de Luís a consideração de ter tido a possibilidade de se colocar, embora se perceba também uma outra indicação, a de que pode contar com a possibilidade de ter uma psicóloga em outro serviço, bem como na entrevista da presente pesquisa. Este oferecimento de recursos humanos ao cliente pode ter o efeito de mascarar uma falta. Pois, junto com a disponibilidade do aconselhador para conversar e tirar dúvidas, há o encaminhamento para a referência, criando ambigüidade. Ao mesmo tempo em que posterga, pode suprimir o uso verdadeiro que poderia ser obtido dos recursos humanos daquela unidade e do momento de aconselhamento no CTA. Essa forma de proceder dá a idéia de um aproveitamento parcial, de uma passagem rápida e sem retorno pelo atendimento daquele serviço. Porque apenas "toca" a superfície de contato do aconselhador com o cliente com a "promessa" de outras paradas, outros contatos. Isso é perigoso, pois há um risco que se corre: o de ficar sem as duas possibilidades de apoio, sem o CTA e sem o serviço 
de referência, ou seja, o risco de ficar no caminho entre os dois.

Isso também já havia sido apontado por Milton (acima). Essa reflexão pode estar relacionada aos sentimentos de impotência que, algumas vezes, os profissionais experimentam ao lidar com as necessidades dos clientes. Talvez esses profissionais do aconselhamento considerem que o outro serviço tenha mais recursos técnicos para enfrentar todas as questões que emergem na revelação do diagnóstico.

No entanto, o próprio cliente está dizendo: esta profissional que o atendeu é muito "carinhosa" (Milton), mostrou sensibilidade, é "maravilhosa" (como dirá Luís, abaixo), "trabalha bem" (Ślvio), e tem tantas outras qualidades. Essas opiniões elogiosas são indicativas de que naquele momento é com este profissional que aquele cliente conta. Mesmo que aquele profissional não lhe possa apresentar a solução de seus problemas, mesmo que o profissional possa apenas escutar o cliente e dialogar com ele, isto não pode ser considerado pouco.

No caso de Luís, na segunda entrevista da pesquisa, ele reforça o que já havia dito anteriormente: houve a possibilidade de que ele colocasse suas questões pessoais, mas nada lhe ocorria naquele momento, além do fato de morar sozinho. As preocupações e sentimentos viriam depois... Compara as aconselhadoras que deram o primeiro e o segundo resultado, ressaltando a qualidade de sua atenção:

"[Foram] diferentes. Mas as duas, umas profissional assim... Maravilhosa, entendeu? Que eu tiro o meu chapéu pra elas mesmo. Que foi uma coisa que elas tenta alegrar a gente e nunca chegar a culpar isso... Troca idéia, conversa, explica a realidade e continua aquele assunto a gente já tá de mente limpa. Quando ela chega no resultado a gente geralmente já tá de mente limpa. E eu falei, o que me preocupou e o que me preocupa até hoje só é, é daqui pra frente, entendeu? É uma recaída, como eu falei, eu moro sozinho, depender de outra pessoa é a pior coisa do mundo. Isso é uma coisa, eu passar mal, eu fazer minhas coisas como assim pra não pedir pra ninguém, entendeu? É só isso. Então eu não tenho ninguém, entendeu? Família é muito distante daqui.

Luís já trazia com ele o sentimento de solidão, e não o associa apenas ao resultado deste teste do HIV.

(...) Não, eu já tinha, mas acumula mais um pouco (...) Eu tô preocupado é assim com o tempo, porque eu conheço pessoas, já tratei de pessoas que teve reações, e as reações não é coisa boa. (...) Vai depender 
do organismo. Então é uma coisa que eu sempre sinto, mas que me dói é isso. (...) Então é isso que eu penso, na hora de fazer um chá, assim, me dá aquela coisa, eu não tenho uma pessoa..."

Há coisas que já foram se constituindo de determinada maneira. É o que esse relato de Luís mostra. Sua história é marcada pelo "estar só". A revelação de sua soropositividade é algo que é acrescentado ao que já existia como faltante. É mais uma coisa que será somada à sua forma de viver só, sem ter com quem contar. É com isso que se preocupa agora. Lá, no momento da comunicação de seu resultado, este assunto não veio à baila. É quando volta para casa, quando pensa no que se passou, que surgem as dúvidas e as questões (a posteriori).

Voltando agora a atenção para Jonas, outro voluntário. Não era a primeira vez que ele realizava o teste. Já viera a este serviço para receber o resultado de mais de um teste negativo. Mas desta vez ele percebe a diferença de abordagem da aconselhadora para dar o resultado. Algo havia mudado.

"Eu até estranhei... (...) Mas, assim, foi super tranqüilo. Na verdade, ela estava preocupada comigo, e pensou que eu ia ter uma reação contrária, mas para mim foi super tranqüilo, não tive nenhum problema. E assim, percebi que foi super profissional da parte dela. Foi até legal, ela, tipo, me deu um apoio que eu me senti forte depois deste resultado...

Será que Jonas pensou que era invulnerável, ou estava testando sua imunidade, como está referido na Introdução deste estudo (AGGLETON 2006)? Voltou para fazer mais um teste porque viveu uma situação de risco. Não acredita de pronto no resultado, leva um tempo para se conscientizar da infecção pelo HIV:

“(...) Foi até uma surpresa quando o resultado veio positivo. E depois eu refiz e o resultado deu positivo novamente. Aí foi que a ficha caiu, mas assim, foi tranqüilo também. Eu não esperava, mas foi tranqüilo.”

Considerou que o espaço foi alargado pela aconselhadora e que pôde ser escutado, tendo o seu lugar garantido para se acomodar.

“(...) Havia, sempre [espaço para se colocar]. E eu tive uma voz, assim, aberto... e eu me abri mais ainda, foi um momento tipo assim, que eu estava no divã, que eu era... que eu tive... uma escuta grande comigo. Foi super aberto, eu falei bastante. Foi muito bom para mim.”

Já na segunda entrevista da pesquisa, após ter transcorrido algum tempo 
desde a revelação do diagnóstico, Jonas relata que teve uma proximidade das aconselhadoras com ele quando voltou ao CTA para a comunicação do resultado da segunda amostra. Mas, continuando a conversar, Jonas aponta para o limite muito tênue entre o carinho e o cuidado, e a repreensão que transparecem no processo de relacionamento humano quando a falha de um frustra o outro, quando a falta da prevenção ensinada e supostamente sabida (aprendida) ocasiona o dano: a infecção pelo HIV. Mesmo que o dano seja em relação ao próprio que não colocou os ensinamentos em prática. Mas, no seu caso, parece ter sido possível esclarecer pelo diálogo. Depois que "caiu a ficha" pôde se responsabilizar pela sua não prevenção (ou vacilo, como ele diz), porque houve tempo para isso. Os lugares ocupados pelo cliente e pela aconselhadora neste aconselhamento permitiram o exercício de suas humanidades. Ele pôde dizer como estava se sentindo:

"Foi meio severo assim. Acho que ela pisou, não que pisou na bola, mas foi muito rígida assim 'pô, você tá condenado, mas ao mesmo tempo, você tem chance ainda', sabe. Eu achei que foi muito duro, isso. Mas foi aquele momento de tensão, mas que de uma certa forma também abriu minha cabeça pra falar ' $m e u$, você tá errado, você tem que assumir que você foi errado e agora, a partir de agora, você tem que estar fazendo diferente'. Acho que foi isso. (...) Eu me expus... Falei o que eu estava sentindo no momento sem medo."

Jonas mostra o lugar ambíguo em que ficou colocado, oscilando entre a racionalidade e a sensibilidade de ambos: dele próprio e da aconselhadora. Um lugar de experimentação ambíguo também em relação ao contato com a susceptibilidade ao vírus e à infecção, e a retomada do rumo da própria vida.

Assim como Jonas, Evandro, o próximo entrevistado, na hora em que estava recebendo o resultado, também percebeu que tinha um espaço de conversa para colocar suas questões. Teve chance de falar sobre como estava se sentindo. Ele realizou duas entrevistas para a pesquisa, mantendo o tempo todo a convicção de que vai obter a cura por intermédio de sua crença religiosa. Na certeza de um poder divino, nega sua condição não de portador de um vírus, mas de portador de uma doença incurável. Isso significa que ele considera sua infecção passível de cura. Encontra-se, também, em um processo de negação da própria homossexualidade.

Ele expressou seus sentimentos e emocionou-se ao receber o resultado, 
pensando na namorada:

“Tanto é que eu chorei um pouquinho, depois eu até pedi desculpas para ela [a aconselhadora]. Mas eu chorei, não por mim. Eu chorei pela menina que eu estou namorando. Porque eu já dei uma grande decepção para ela e chegar agora com mais uma dessa. Mais essa decepção! Aí por isso que eu chorei, não por mim."

Evandro considera que a primeira decepção dada à namorada foi quando contou a ela que tinha práticas sexuais com homens, antes de conhecê-la. Respeitando e acolhendo os sentimentos de Evandro, a pessoa que estava falando com ele o escutou:

"Ouviu, tanto que ela foi buscar água para mim. São essas pequenas coisas que a gente lembra né? (...) Sim, ela perguntou se eu queria um cafezinho, ou uma água. Eu aceitei uma água. Aí ela pegou uma água, ela foi buscar para mim. Enquanto ela foi buscar a água, eu me fortaleci de novo."

Como ele diz, são pequenas coisas que fazem a grandeza do espaço e do tempo. Bastaram alguns instantes de atenção para que ele "ativasse seus recursos internos" e se fortalecesse.

Já na segunda entrevista, quando indagado sobre o que se passa na comunicação do resultado, as dificuldades sentidas, as possibilidades de falar e sobre o tempo para se colocar, relata:

"Ah, é um pouco difícil, porque também, você tem que falar de sua vida, você tem que ficar falando do seu passado, também. É um pouco difícil, neste sentido (...) Eles dão o maior tempo para você falar da sua vida... Fala se você tem alguém, fala da sua vida, o que está acontecendo (...) Assim, eu me senti assim acolhido. (...) Pelas palavras que ela estava me falando que foram boas."

O que é difícil para este entrevistado é falar sobre o passado que ele quer esquecer, pois ele representa tudo o que ele quer rejeitar, reprimir e negar: é o que diz respeito às suas práticas sexuais homossexuais. Seu presente de moço que namora para casar se opõe ao seu passado. Quanto ao aconselhamento, nesse contexto parece que Evandro teve o lugar central preservado e o centro da conversa havia sido ele. 
Como Evandro, Juvenal participou de duas entrevistas da pesquisa. Mas diferentemente do primeiro, este aceitou sua soropositividade como um fato que não seria negado. E, de certa maneira, o fez de forma complacente. Começa contando que foram duas aconselhadoras diferentes que deram o primeiro e o segundo resultado.

"Mas todas as duas, elas atendem bem, deixam você bem à vontade, deixam você... Fazem perguntas se você tiver alguma dúvida".

Ele refere que não esperava o resultado positivo, apesar de não fazer sexo seguro sempre.

“(...) Quando você sente o momento, então... Você não espera, e de repente... Uma bomba dessas, então... (...) Realmente, você faz [o exame] né, fica naquela preocupação e tal, mas você... Você sempre espera negativo, né? Mas, infelizmente... (...) Ela ouve você. 'Agora, estou à disposição sua também se você quiser voltar, marcar uma hora pra conversar, tirar alguma dúvida..., ",

Diz Juvenal, repetindo as palavras da aconselhadora: "Estão à disposição.”

Apesar dessa disponibilidade oferecida, Juvenal não voltou para outra conversa. Novamente, a passagem rápida pelo serviço, com a indicação do caminho ao serviço de tratamento aparece, como foi também observado com Luís e com Milton.

"Não [voltou]... É por que... No dia que eu passei já marquei entrevista com você, então... Eles já me deram o encaminhamento aqui em Santo Amaro, pra fazer o tratamento, então... (...) Perguntaram assim pra mim: como é que você está se sentindo? O que eu posso fazer? Vou me desesperar? Não... Da minha parte eu tenho de aceitar o problema, né, porque eu procurei. Como se diz: quem procura acha."

Ele sentiu que era o centro dessa comunicação, a conversa estava focalizada nele:

"A atenção fica todinha voltada pra você, naquele momento, né. Se fosse ao contrário, se o resultado tivesse sido outro [negativo], teria que ter uma atenção mais diferenciada. É... Porque aí a pessoa não tem tanto sabe, vai conversar com você, tudo. Vai explicar tem hora que "a mais", não vai ser a mesma coisa quando é [negativo]"

Juvenal supõe que o interesse é o que determina a diferença entre a 
comunicação do resultado positivo e do negativo: "É o interesse, o interesse."

$\mathrm{O}$ interesse que, segundo Juvenal, aumenta no momento em que a pessoa recebe o resultado positivo.

"Ela [a pessoa que recebe o resultado] acha até que é um apoio, um apoio... Da parte deles... Tem realmente um interesse."

Ainda sobre esta questão Juvenal conta, na segunda entrevista, sobre o espaço que foi aberto, mas não foi ocupado por ele, já que não voltou ao CTA para falar sobre seus sentimentos. Parece tratar-se de um paradoxo, uma vez que ele reconhece a possibilidade de voltar ao serviço como produtora de alívio, mas ao mesmo tempo, não se movimenta na direção disso, mantendo seu estado de tensão. Contudo, não considera difícil voltar pra conversar com alguém no CTA. Justifica que, no dia em que teve vontade de ir ao CTA para falar com alguém, não foi, pois estava sem horário. Mas acha importante saber que pode procurar um profissional pra conversar sobre suas dúvidas. Assim, parece ser importante o oferecimento feito pelas aconselhadoras de um horário adicional. Ele diz que ter com quem conversar é um alívio. E dá a razão para sua afirmação:

"Porque você se solta, fala... Não fica com aquela coisa, guardando. (...) É importante, né? Porque a pessoa vai te orientar, vai tirar sua dúvida para poder te ajudar, né? Então, se você vai conversar isso com uma outra pessoa [leiga], ela ao invés de te ajudar, acaba te atrapalhando. (...) Eu acho até que por ser um profissional formado é até mais fácil [falar de coisas pessoais], né? De você se abrir, de falar."

Arnaldo, o entrevistado seguinte, recebeu o primeiro resultado na presença de duas profissionais. Uma delas estava em processo de treinamento para fazer parte da equipe de aconselhadores daquele CTA. Na comunicação do segundo resultado, foi atendido por uma outra aconselhadora que investigou um pouco mais sobre a via de infecção pelo HIV, tentando dialogar com ele sobre isso, mas respeitando as informações dadas por ele na sua ficha. Observou-se certa relutância de Arnaldo em aceitar ter vivenciado uma situação de risco sexual, adotando a posição de ter se infectado por acidente com material pérfuro-cortante no ambiente doméstico. $\mathrm{Na}$ ocasião, estava envolvido um colega dele, cujo diagnóstico de HIV positivo não era ainda conhecido. Mais tarde, este colega teve o diagnóstico revelado. A mesma 
posição quanto à via de infecção foi mantida por ele na entrevista com a pesquisadora. Sua versão quanto à via de infecção é respeitada, o que não impede que se levante a hipótese de que esteja em curso o mecanismo de negação da própria experiência sexual desprotegida.

Arnaldo conta que se sentiu no centro da conversa quando da revelação do seu resultado positivo, pela forma de ser abordado pela aconselhadora:

"Senti. Porque até então quando você tá aqui cara-a-cara, olho-no-olho, a sua única... Você entra aqui e você não espera escutar um não. Quando o psicólogo te chama pra conversar, você não tenta escutar um não, você vai esperando encontrar um 'sim, você está contaminado' porque, em minha cabeça, não passou em momento nenhum que ela ia falar que eu não estava. (...) Eu tive essa sensação porque eu acho que se eu não tivesse nada, ela ia simplesmente, a conversa não ia demorar, ela não ia dar tanto rodeio, ela não ia me preparar tão bem pra poder me falar..."

O pensamento de Arnaldo parecia estar oscilante entre a positividade e a negatividade de seu resultado, não apenas pelo caminho percorrido pela aconselhadora em direção à notícia. Pois, foi exatamente este caminhar com ela que lhe permitiu transitar na própria experiência de entrar em contato com sua infecção. Foi o objeto cortante ou foi uma relação sexual desprotegida? Não há necessidade de ter essa dúvida respondida. A dúvida pode ser mantida enquanto ele expõe outras preocupações. Ele tem oportunidade para tal:

"Mas eu fiz, eu fiz colocações. (...) Ela abre esse espaço... Eu fiz colocações. Eu falei que se minha família sonhasse com uma coisa dessas, que era muito mais prático pegar uma bala e dar um tiro na minha cabeça por que... E ela falou 'não, não, não é bem por aí não'. Ela te dá o espaço e te explica aquilo que você não tem explicação."

De um modo diferente de Arnaldo, Pedro assume inteiramente a sua falta de proteção frente ao vírus HIV em sua última experiência amorosa. Fala menos do momento em si da comunicação do seu resultado. Está ainda muito impactado pela perda do seu companheiro. Requereu boa parte do tempo da entrevista para falar disso. Vive ainda o processo de luto, tal como descrito por FREUD (1925) no qual, o sujeito vive uma reação à perda do ente querido e por um período de tempo “... a sombra do objeto caiu sobre o ego" (p.281). Pois, seu espaço psíquico estava, 
naquele momento, ocupado, eclipsado mesmo pelo seu objeto de amor desaparecido. Seu pensamento estava sombrio e ensombrado. Enlutado. Era muito difícil pensar em si mesmo sem pensar nesse outro, ainda parte de si mesmo. Em conseqüência, foi difícil abordar os assuntos de interesse da pesquisa, sendo necessário ouvir os detalhes da história de adoecimento e morte do companheiro de Pedro, como pode ser visto no seguinte trecho da entrevista:

Pedro: "Olha, da forma que eu recebi eu falei, né, a primeira vez. A forma que eu recebi... Muito... Foi, foi ótimo da maneira que elas me falaram, né, que passaram o resultado..."

P: Então, como foi essa maneira? Como é que ela começou?

Pedro: "Primeiro ela... Na primeira vez a [nome da primeira aconselhadora], ela chegou e conversou um pouco comigo, né? E eu falei um pouco, né, de tudo que aconteceu, tudo assim. Aí depois que ela veio me dar o resultado, né? Foi o resultado que eu já esperava, tal, que eu já esperava porque não tinha como, né, dizer que poderia dar negativo... $\mathrm{E}$, assim, não tem nem como, sabe assim... Eu não posso dizer que me choquei porque o choque na época que eu tive mais forte pra mim foi perder meu parceiro, né... Então, poderia ser qualquer resultado, até de... Sei lá... Talvez, não HIV, de qualquer outro tipo de resultado, tivesse seis meses ou tivesse só um mês, pra mim não ia mudar, porque a pior dor pra mim foi a perda do... (...)"

P: Pedro, nesse momento que você recebeu o resultado aqui, você teve oportunidade de falar das suas coisas, das suas preocupações, dos seus sentimentos?

Pedro: “Aqui? (...) Ah, eu falei... Eu falei a minha história, né. (...) Porque, assim, na hora eu até pensei, né, sabe... Um pouco eu me perdi... Um pouco né. Fiquei meio preso, não sei se eu fugia ou não, se me expressava mais, se chorava mais. (...) Na primeira vez a gente fica meio sem jeito. (...) Eu fiquei um pouco assim, né, assim tímido eu posso dizer que um pouco. Mas, aí depois que ela me deu o segundo resultado, como eu falei: '...eu sei que não vai dar negativo'. E assim, eu queria assim, pra mim, como eu estou sentindo até hoje eu queria que ela tivesse falado pra mim que me desse o conselho: 'oh, quando você estiver pensando nele assim meio triste, quando estiver quieto em casa, tente não pensar...' Assim, que me desse um conselho assim, ou uma opinião, não sei. Só que eu tenho que esquecer ele mais um pouco, sabe. (...) É, eu queria que fosse falado alguma coisa pra mim assim: 'olha, na hora que você tiver... tipo triste, né, pensando no que aconteceu, (...) faz isso, isso, isso’ (...) 
Mas assim, na hora eu até que fiquei mais quieto. Eu queria que ela falasse alguma coisa, né?"

Em outras palavras, o que Pedro desejaria era ouvir, mais do que ser ouvido, que a aconselhadora dissesse mais a seu respeito do que ele mesmo poderia dizer naquele momento. Todavia, ele é capaz de elaborar mentalmente (e de verbalizar) quais seriam as palavras que queria ouvir da aconselhadora. No estado em que se encontrava, ainda não tinha todos os recursos internos mobilizados para se defender do sofrimento, que naquele momento era o da perda do companheiro. Por que, o sentimento pela perda da sua condição de soronegativo, ainda não tinha entrado completamente em cena. Precisava utilizar o apoio de outrem.

Como o de Pedro, o parceiro de Mário, o próximo entrevistado, é soropositivo. Mário sabia disso desde o início de sua convivência. Este parceiro acompanhou Mário ao CTA para buscar o resultado. Mário considera que o resultado positivo não ocasionou a perda do parceiro, mas uma certa aproximação dele.

No momento da revelação do seu resultado, Mário considerou que teve espaço de comunicação com a aconselhadora, como ele conta:

"Bom, o resultado foi dado, assim, com muita cautela, com muito cuidado. Ela perguntou se eu queria saber alguma coisa antes de abrir o resultado, olhou bem dentro dos meus olhos, assim. Eu estava com pressa, né. Estou sempre com pressa de saber os resultados dos exames... Para eu abrir. Ela abriu, depois a gente conversou. Depois do resultado. Mas foi um... Um choque, né? Uma dor no coração, aquele aperto, uma angústia que dá na hora. Continuei conversando com ela e respirando fundo. E conversando... Tive uma sensação que nunca tinha sentido antes.' (...) "Eu fiquei refletindo sobre as coisas que ela estava falando.”

Mário não fez referência ao conteúdo da conversa que teve com a aconselhadora. Diz apenas que ficou refletindo sobre ela, e esse termo é dele. A realidade parece ter se apresentado aos poucos para ele após o "choque" do resultado positivo.

Bruno, o mais jovem dos entrevistados, já tinha familiaridade com o serviço e com a aconselhadora que lhe fez a revelação do diagnóstico de HIV positivo. E, assim como Jonas, tinha também bastante conhecimento das formas de prevenção do vírus HIV. Fez a entrevista de pesquisa no dia em que veio espontaneamente ao CTA 
para conversar novamente com a aconselhadora.

Ele fala dos efeitos nele em termos de sentimentos, a partir de seu diagnóstico:

"Eu fiquei muito triste. Senti muita confiança nela [na aconselhadora] também, tanto é que hoje eu voltei e fui procurar ela. Eu falei: quero falar com ela agora. Confiei muito nela. Ela me transmite uma certa confiança, agora. Não sei, parece como se fosse uma segunda mãe, sabe? (...) Que eu tinha que vir aqui só amanhã, na terça-feira. Falei: 'não, eu vou hoje, que eu quero conversar com a [nome da aconselhadora]. Quero ver o que mais ela tem pra me falar'. Como eu estava sentindo antes... Porque no dia eu não quis conversar muito, eu não tinha como contar pra ela. Aí ela me ajudou e hoje a gente conversou mais um pouco a respeito disso. Eu contei o que eu estava sentindo, das glândulas que apareceram..."

Assim, Bruno teve espaço para falar com a aconselhadora sobre o que estava sentindo. A confiança mediava o aconselhamento: ele sentia que ela dava importância ao que ele trazia. Conta com o apoio daquela aconselhadora que o acolhe, mesmo que ele não tenha marcado horário. Pode-se refletir que é a confiança o que determina a volta ao CTA para mais encontros de apoio e orientação. Mas o modo como é estabelecida essa confiança parece ser o aspecto fundamental a ser perseguido nos aconselhamentos.

“É, então. Eu sinto ainda que eu posso confiar nela. Tenho certeza que a hora que eu chegar aqui ela vai... Que nem... Ela chegou, eu tava lá embaixo ainda ela foi, me cumprimentou, eu cumprimentei ela. Perguntei pra ela... Nem tava marcado nada. Só pedi pra ela se eu podia falar com ela. Ela falou: 'vamos subir, então.' Aí subi com ela. Ela já me atendeu antes. Tinha até gente esperando ela. Ela me atendeu pra gente conversar. Ela está sendo ótima, sabe? Tá tendo paciência comigo de uma certa forma, porque eu não sei nada a respeito, trocando por miúdos, só algumas coisas das prevenções que tem que ter do que não tem... Mas, sentimentalmente, eu não tenho ninguém pra dividir isso, entendeu? Aí eu estou conversando com ela. (...) Agora ela [aconselhadora] que teve que agüentar, né? Ficar escutando o que eu tenho pra falar... (...) Eu não vejo ela assim como uma, como uma médica, como uma psicóloga. Eu vejo ela ali agora, acredito que eu estou vendo ela assim, entendeu, como uma amiga. Ela... Meu primeiro exame negativo, minha amostra negativa, foi ela que me entregou, sabe? A segunda amostra, não. E essa 
agora que deu positiva, também foi ela. Então eu sinto uma certa cumplicidade com ela assim, entendeu? Eu sei que passam milhões de pessoas por ela, que às vezes pode ser que eu vá embora e ela nem lembre que eu esteja aqui, que eu tenha vindo aqui. Mas pra mim não, entendeu? Eu sei que qualquer coisinha que me der eu vou ligar pra [nome da aconselhadora]. Ela me deu o telefone daqui também, de cima, pra eu poder falar com ela... Pra qualquer coisa que eu precisasse. Ela está sendo ótima!”

E ele entendeu que a conversa estava toda voltada para ele em sua singularidade, sentindo-se em um lugar sobre o qual estava o foco da aconselhadora. Mas tem também a percepção do espaço de troca, do espaço constituído pelo diálogo que é mútuo, dos dois.

"Exatamente! Tudo o que ela queria era só me ajudar, entendeu? Ela só queria me mostrar o caminho. Tudo o que ela queria era me ajudar e se você não dá espaço também para a aconselhadora te ajudar, não tem como ela fazer nada, né? E é isso que eu tô tentando fazer, tô abrindo um espaço também, para ela me ajudar. Do mesmo jeito que eu confio nela, entendeu? Que eu sei que ela não vai, que ela vai procurar sempre alguma coisa melhor pra mim, porque ela entende, não entende? Disso? Não é assim? Ai então, eu acho que ela vai saber o que falar, o que fazer ou não, entendeu?"

Esse espaço mútuo formado por Bruno e sua aconselhadora parece não ter sido possível de ser criado entre os dois próximos entrevistados e suas respectivas aconselhadoras. As versões de Omar e Paulo são as mais negativas a respeito do aconselhamento pós-teste. Começa-se pelo primeiro.

Omar não se sentiu o centro de sua comunicação do resultado. Por essa razão, nem cogitou sobre a possibilidade de falar com a aconselhadora sobre seus sentimentos e preocupações. Omar transmite sua versão negativa fazendo uma análise do que se processou naquele momento, tentando criar diálogos fictícios com a aconselhadora, nos quais imagina que o cliente possa se sentir mais acolhido. Percebe que há uma positividade que pode emanar do espaço de comunicação do resultado, e que pode produzir efeitos sobre o cliente, mas isso não ocorreu com ele. Fala de uma impessoalidade da atividade de aconselhamento:

“(...) como eu acho que não houve uma preparação, pra você dar a 
noticia, porque se preocupou em preencher os documentos administrativos que faziam parte do processo, então qualquer pergunta que se fizesse ali em relação ao meu sentimento, ali já não era mais válido. Assim, não tem mais... Aliás, não surte nenhum efeito. Entendeu? Por mais que você tente confortar a pessoa, não vai surtir nenhum efeito, né? Então assim, o que que é legal numa situação? O que eu... Eu me colocaria no lugar da pessoa. . Eu que vou passar a informação pra essa pessoa? Legal. Então vou me colocar no lugar dela. Não tornar a coisa muito seca ou então, é... Mais um! Entendeu? Assim... Uma coisa corriqueira. Porque todo dia você faz a mesma coisa, então você acaba perdendo a sensibilidade. É isso que eu senti. E isso é natural do ser humano. Eu até entendo um pouco isso, mas você, eu acho que você sempre tem que estar se reciclando né, pra você não passar essa imagem que foi a minha percepção."

Ele repete que teve a sensação de ser mais um dentre os demais clientes que vão ao serviço. Nota-se no trecho acima, e também no próximo, um ressentimento que pode ter determinações da própria experiência intersubjetiva ocorrida entre cliente e aconselhador. No entanto, pode haver outras determinações que serão analisadas quando se adentrar nos aspectos mais dinâmicos da análise do processo de aconselhamento. Omar sinaliza que ficou confuso, que ficou em conflito, que pode não ter se apresentado de forma a aceitar a aproximação da aconselhadora.

“É, mais um. Ponto final! É, e aí: 'estou cumprindo meu papel, já passei a informação, e tudo bem, acabou.' Na segunda vez que eu fui, que foi o dia que fui indicado [para participar da pesquisa], tal, a pessoa que me colocou [o resultado], conversou comigo e tudo mais, me pareceu ter mais sensibilidade, né? Acho que ela tinha até um pouco mais de idade em relação à primeira pessoa, então eu senti um pouco mais acolhido, né? Mas eu já sabia do resultado... (...) Ficou uma lacuna, né? Assim, ficou aquele... Sabe quando fica um vácuo? 'Eu passei a notícia e as perguntas de praxe.' [Fala como se fosse a aconselhadora pensando em sua rotina] Não, não, eu recebi a notícia, né? E aí... E aí fiquei pensativo. 'Tudo bem Omar?' ... 'Quê que você está sentindo?' Assim, mas sabe quando você... Ou talvez eu posso estar até confundindo pelo fato de eu estar com uma emoção, ali, e um conflito e tudo mais, um choque, né, pode ser. É... Mas, eu não consegui, sabe? É... Extravasar. Eu acho que a gente precisa disso, né? Eu acho que eu precisava desse momento. E que não ocorreu. E até agora não ocorreu isso, eu não tive isso. É... Mas que eu fui deglutindo essa idéia e fui ficando mais tranqüilo, mais calmo, e 
aceitando a situação. Eu precisava, né, eu achei que precisava até extravasar, precisava colocar (...) o meu sentimento, falar algo mais. 'Omar fala o que você está sentindo'. Ou então é... Porque vocês usam de meios que psicólogos, enfim o profissional que lida com isso, tem alguns meios pra fazer com que a gente consiga dar uma aliviada, enfim, é... Faltou um pouco de experiência, um pouco de sensibilidade pra fazer com que eu pudesse, sabe, sair de lá assim... Porém, eu já estou um pouco mais aliviado com aquela coisa no peito, entendeu? Sabe aquela coisa é... Que você se fecha? Enfim.”

A lacuna referida por Omar é grande e ele reage. Ele demora para buscar o resultado do segundo exame. Omar sentiu que houve esforço da aconselhadora para que ele colocasse seus sentimentos, mas ele não conseguiu utilizá-lo. Apesar da falta de sensibilidade narrada, indagado sobre o espaço para ser escutado, Omar sentiu que ele ocorreu naquele atendimento, ele teve um lugar ali, apesar de ele não o ter utilizado:

"Então... Houve. Até houve, mas assim, dada a circunstância, eu acho que... Sabe quando eu ou já não queria falar mais nada, ou queria ficar no meu canto, ou então devido ao sentimento. Entendeu? (...) Eu acho que talvez se ela tivesse... Perguntado mais... Ou então buscado isso em mim, eu acho que poderia ter... Entendeu? Então, é isso. 'Você está sentindo alguma coisa?' 'Você quer falar alguma coisa?' 'Não.' 'Então tá.' Ponto!"

Assim, pode-se relativizar um pouco o discurso de Omar. Até porque, nota-se nele um nível grande de exigência em relação a si mesmo e ao outro. Mas também se deve ter em conta o fato de que, como ele, outras pessoas podem viver a sensação de ser mais um, de não ter um lugar central no próprio atendimento, e o fato de que um dos objetivos do aconselhamento é justamente a sustentação das angústias, preocupações e sentimentos dos clientes. Omar não teve a sensação de ser o centro da conversa:

"Não, pra mim não tive esse sentimento. Pra mim é... 'Vamos aqui preencher os formulários, bom, seu teste é tal', e aí, pronto! Aí fiquei quieto... E aí se passou um tempo: 'tudo bem?' 'Tudo bem'. 'Tá'. Então agora ela fez algumas perguntas de praxe tipo: ‘você está bem?' Ou: 'você quer falar alguma coisa?' Ponto! 'Agora vou preencher alguns documentos pra gente fazer um novo teste'. Ponto final! 'E aí vamos fazer um novo teste'. Desci, fiz e acabou e voltei de novo. Foi isso. (...) Sabe aquela coisa assim básica? Assim, tipo, é... De você ir num lugar, 
vai comprar um refrigerante: compra, sai, paga e você fez o que tinha que fazer, e vai embora, entendeu? Ponto final!"

A mesma sensação de "atendimento automático" foi sentida por Paulo em seu primeiro aconselhamento pós-teste.

“(...) Eu não sei qual a solução do meu problema; mas o único problema que eu tenho neste momento é angústia, mas como você perguntou do comunicado, ele foi muito rápido! [Fala cada palavra com cadência, como se soletrasse] Cada ser humano tem uma posição diferente, tem um lado emocional diferente, tem um psicológico diferente... Todo mundo ainda tem uma esperança de que está negativo, mas vê que está positivo. É... eu não sei, mas de repente a função da profissional é essa mesmo...”

Ele não sentiu que teve oportunidade de falar sobre o sentimento que teve no instante da comunicação do resultado: o de achar que era negativo e foi soropositivo...

"Não, não senti. Eu acho que foi muito a recepção de quem tava recebendo a pessoa... Na minha cabeça! (...) Não sei, eu senti um certo distanciamento... (...) Eu estou falando de como eu recebi e é complicado falar de quem está lá; a posição sua é uma [posição da aconselhadora] e a minha é outra. Mas..."

A pesquisadora pergunta sobre que posição é a sua. Ele diz:

"Minha sensação? De que? Da notícia? (...) Bem automática! (...) Imagina que você tem o cartão do Banco 24 horas, seu cartão entra e sai. É isso. Se você quer saber se houve alguma preparação, tipo assim, psicológica ou como lidar com o lado emocional. Na minha cabeça, não houve! Preparo emocional não houve, se você quer saber. (...) Não existiu!"

Nem preparo, nem espaço para colocar seus sentimentos e emoções:

"Não... Não houve espaço. Esse espaço foi questionado depois, quando eu estava levantando, aí já não, se depois dessa notícia já não houve preparação inicial, por que que eu vou, vou querer depois? E na hora, pra quem recebe uma notícia dessas, você gela! Eu estou aqui conversando contigo, eu estou gelado!"

Essa última fala de Paulo é muito parecida com a de Omar, acima.

Em seguida, a pesquisadora pede esclarecimento sobre os momentos finais do 
aconselhamento, quando ele se levantou para ir embora. Ele havia contado que a aconselhadora deu-lhe uma oportunidade para falar.

“É, ela perguntou se eu queria falar de alguma coisa, (...) mas eu não senti... Como é que diz?... Eu não senti... Na verdade, (...) você se sente uma pessoa muito frágil. Então, a posição que quem tá aí ocupa [aponta para o lugar onde a pesquisadora está], é uma coisa, é um trabalho como outro qualquer, como eu trabalho. Eu também trabalho com gente. Mas a diferença está no sentimento, que vai ter que lidar com uma notícia que ninguém espera. Então, assim, (...) acho que a profissional fez o trabalho dela. Só que não houve, assim, o interesse, não houve o interesse e a preocupação com o emocional com o positivo ou o negativo. Porque todo mundo que chega aqui chega ansioso... (...) Quando a gente vem aqui, a gente vem... É... Procurando o que eu tô procurando: só um pequeno alívio, entendeu?"

É importante lembrar que, historicamente, as pessoas procuravam o aconselhamento psicológico para buscar a resolução de seus problemas e a tomada de decisões. O aconselhamento em HIV também tem as mesmas finalidades, mas se concentra nos aspectos que estão relacionados à sorologia positiva: suporte para angústia, adesão ao tratamento, e adoção de práticas preventivas. Assim, o que Paulo necessita parece estar incluído, pois ele fala de buscar alívio para sua angústia. A pesquisadora explora um pouco mais sobre o modo como o cliente entende que poderia obter alívio, uma vez que esse era o seu desejo. Solicita sua opinião: - você acha que aqui é um lugar que dá para ter esse alívio? Quando você fala 'eu estou procurando um alívio', você acha que pode ser criado um espaço aqui, nesta conversa? Ele responde:

"Pode, eu não tenho ninguém pra conversar, [diz o nome da pesquisadora]. Eu vim hoje pra poder conversar [com a pesquisadora] pra pegar o segundo resultado. Aí até lá eu estou super angustiado, agoniado. (...) eu não tenho com quem conversar, eu vou num centro [de saúde], eu não acreditava muito nesses centros de... Só que não notei interesse, (...) ou o tempo é curto, [nome da pesquisadora]? (...) Foi muito rápido! 'Vamos descer para a segunda coleta'? Eu achei muito rápido! Quando você se sente... claro que eu posso chegar muito bem aqui e pegar o resultado, como meu amigo: 'escuta, eu não quero rodeio e eu quero tirar logo o resultado' é um direito que assiste a ele; é um direito que assiste a ele. Eu não! (...) Então a minha preocupação é assim... Não tem essa de: como eu peguei, mas pra quem eu passei... se eu passei. E sentimento de 
culpa indiretamente porque eu não sabia que eu estava... contaminado.”

Ele pensou sobre isso e refere ter sentido um pouco de culpa, apesar de não ter conhecimento do seu status sorológico antes. Não teve oportunidade de falar disso com a aconselhadora. Poderia, tendo oportunidade, aliviar um pouco a culpa por meio da reflexão e elaboração mental a respeito das situações vivenciadas anteriormente nas quais houve risco de infecção de seus parceiros.

"Não, não foi me dada a oportunidade. É isso que eu estou falando. É isso que você precisa... ir atrás na sua pesquisa; deveria dar essa oportunidade pra pessoa... Deixar o que tá aqui falar! [Bate o dedo indicador apontando a pessoa que está do seu lado da mesa.] Porque é o primeiro contato que tem é com quem tá aqui, é com o profissional, entendeu? (...) É a única coisa que você tem pra se agarrar no momento..."

Sentindo-se em desamparo e solidão, com questões pessoais e situações vividas para as quais precisava suporte, este entrevistado tinha a expectativa de poder falar na situação de aconselhamento. Por diversas vezes nas entrevistas, Paulo referiu-se ao fato de ser sozinho. Segundo ele, se pudesse ser escutado, o efeito do resultado sobre o cliente poderia ser diferente, como aponta:

"Por pior que seja o resultado positivo... Quem tá aqui tá sempre cheio de esperança, nunca vai achar que não vai dar negativo, entendeu? Quer ser ouvido, né. Não vai ter a solução do outro lado porque não vai tirar o 'dito cujo', o vírus já está lá. Mas, assim, tem gente que sente necessidade de ser ouvido."

Paulo está falando de si mesmo, de sua necessidade de ser ouvido. Ele ainda reafirma o sentimento de que, no primeiro aconselhamento pós-teste do qual participou, não foram ouvidas nem as suas preocupações, nem o seu lado emocional:

“... o que veio na minha cabeça é assim: 'e agora, o que é que eu faço?'...um desses itens que você falou, não lembro o que é, como é que você vai tentar amenizar o emocional de quem ganhou o resultado positivo? Só amenizar, não é solucionar. Se você dá uma amenizada pra pessoa conseguir ter força nas pernas inclusive pra descer essas escadas aqui... E cruzar com pessoas que estão saindo com resultado negativo e o sorriso está estampado no rosto. E você está com o resultado positivo, você dá um sorriso amarelado... Pra não aparentar que você está positivo pra quem você nunca viu na vida, pra quem está aqui fora." 
Paulo aponta para o lado social e coletivo da instituição. Tem outras pessoas que ali circulam e que podem saber de seu status sorológico pela sua expressão facial. Isso ocorre porque a organização dos setores de atendimento é estruturada de determinado jeito. Assim, essa circulação de pessoas permite que elas se cruzem nos corredores, ao entrar ou sair de determinadas salas.

Após essa primeira experiência de comunicação de seu resultado, Paulo recebe o resultado da segunda amostra e sente diferença para melhor, quanto ao atendimento da aconselhadora. Desse modo, pode desenvolver um pouco melhor o processo de elaboração do seu diagnóstico. Pode aplacar um pouco sua raiva e reacender a chama da esperança reivindicada por ele antes. Não a esperança do teste ser negativo, mas a de poder ter um espaço compartilhado (no qual pode ser escutado). Na segunda entrevista da pesquisa ele comenta:

"Hoje eu fui atendido por uma profissional diferente. Embora eu tivesse esperançoso, no fundo eu achava que, eu acho que essa confirmação é sempre igual ao primeiro. Eu acho muito difícil dar negativo. (...) Porque toda aquela, aquela angústia que eu sentia no primeiro... Quando eu vim pegar o resultado do segundo já não é, já é diferente. Já estou maquinando na minha cabeça como conviver com isso. Na verdade, até a postura da pessoa é diferente... $\mathrm{Na}$ verdade, eu acho que ele tá mais preparado já, né, daquele primeiro contato que eu te falei, aquilo que é importante. O segundo já... que eu fiquei em casa pensando nisso, pensando, pensando... Esperançoso, mas porém, mais... Segurei o resultado com mais firmeza. (...) Desiludi, na verdade. Então, assim, o primeiro contato é que é importante, se você quer saber... (...) Mesmo tendo levado o baque do primeiro. Então, no segundo eu estava, na verdade, por mais que eu tivesse esperança que esse exame desse negativo, eu estava, eu disse, eu já estava mais... Como eu vou te falar? Eu tava mais polido [no sentido de preparado, trabalhado], né?"

A pesquisadora pergunta como foi a segunda comunicação (que havia sido naquele mesmo dia).

“É... Eu criei prática... (...) É, eu cheguei, ela sentou, ela puxou o papel e falou assim: 'sem rodeios, eu vou dar logo o resultado e depois a gente conversa: positivo'."

A segunda vez que Paulo recebia a comunicação do resultado foi parecida com a primeira, mas como ele mesmo disse, ele criou prática. Ou seja: ele já chegou 
sem ilusão e a aconselhadora, apesar de prática e sem fazer rodeios, abriu por meio de suas palavras o espaço de conversa. Algo se operou ali que permitiu que Paulo adentrasse o espaço da revelação do seu diagnóstico. Eles puderam conversar, e ele pôde ser escutado, como ele relata:

"Aí depois conversou bastante, um pouco mais, entendeu? Aí eu tirei algumas dúvidas com ela. Muito simpática por sinal, bem diferente da primeira, entendeu? Ela foi prática no resultado, parecido com a primeira, mas, em compensação, se predispôs a estar me ouvindo, a tirar dúvidas... Eu tirei dúvidas, me indicou um local, fiz umas perguntas, ela me respondeu, entendeu? Não se mostrou muito. É... Ansiosa pelo tempo. (...) ...se eu quiser tirar mais dúvidas ou se eu quisesse voltar pra conversar, eu podia voltar pra conversar. (...) É, senti que eu podia me colocar. (...) O trabalho foi mais... Parece que o trabalho foi mais elaborado... Mais atenciosa."

Paulo, após sair impactado por ter a sorologia positiva e por não ter se sentido com tempo e lugar para colocar suas questões e ter apoio para elas, tem um tempo de elaboração da perda da condição sorológica negativa. Nesse intervalo, participa da entrevista de pesquisa, na qual pode se expressar livremente a respeito da experiência emocional vivida e alguém o estava ouvindo. Os dois fatores (tempo de elaboração e tempo de escuta) parecem ter tido efeito favorável à uma melhor condição psicológica para retornar ao serviço em busca da confirmação do resultado, e para a continuação da pesquisa por meio de outra entrevista. Sob esses efeitos, Paulo participa da revelação do outro resultado, de forma "mais elaborada" segundo ele. O que ele está chamando de mais elaborado tem a ver com o trabalho e a posição da aconselhadora ao lhe comunicar o resultado da sua segunda amostra. Conseqüentemente, essa ação também teve efeitos favoráveis à elaboração mental da soropositividade. A aconselhadora desta vez estava disponível (era outra) e isso foi bom para ele:

"Pela disposição de me ouvir, de tirar minhas dúvidas. Não se mostrou uma pessoa ansiosa como... Tipo assim, com o resultado, fiz umas perguntas e, tipo assim: 'bom, eu tenho que ir embora, será que já acabou?' Ela me deixou à vontade, até no final ela perguntou: 'você tem mais alguma coisa que você quer perguntar?' Eu falei assim: 'não'. Aí eu levantei, dei tchau pra ela e ela falou: 'você está bem?' Eu falei: 'tô'. E ela: 'se você quiser voltar pra conversar, é só marcar uma hora'." 
Como se pôde observar nos relatos dos entrevistados, a característica de proporcionar aos clientes um espaço no qual eles podiam falar de suas preocupações e sentimentos, e ter um lugar central no processo de comunicação aconteceu para maior parte deles. O que não significa que a sensibilidade do aconselhador para essa escuta tenha estado presente em todos os casos. Há indicações dos clientes de que isso pode ser melhor explorado e oferecido. Tal como no estudo de FILGUEIRAS e DESLANDES (1999) relatado na revisão de literatura, essa diretriz do aconselhamento (de acolhimento e escuta) encontra-se muitas vezes prejudicada nos serviços. Nos casos investigados, uma tendência nos aconselhadores que dificulta a escuta é a de seguir o protocolo sem iniciar o trabalho de revelação do diagnóstico pelo que o cliente traz como demanda. Todos têm uma demanda. Paulo ensina um pouco do trabalho quando diz: "Cada ser humano tem uma posição diferente, tem um lado emocional diferente, tem um psicológico diferente... Todo mundo ainda tem uma esperança de que está negativo, mas vê que está positivo".

É importante que a esperança de vida seja reativada neste encontro, por meio da oportunidade da escuta às angústias que o permeiam. Ademais, Paulo confirma e reafirma a posição subjetiva que cada pessoa ocupa no mundo e em relação à sua história de revelação do diagnóstico. Ele dá as pistas do melhor caminho a seguir para realizar o percurso em cada história.

A categoria que será examinada a seguir trata de um aspecto um pouco mais técnico, já que enfoca a abordagem no aconselhamento pós-teste às práticas de prevenção e cuidado. É uma característica que depende de ter havido sucesso no aspecto abordado na categoria precedente, pois se o espaço de compartilhamento e de confiança não for instaurado, dificilmente o cliente se apropriará das orientações e encaminhamentos do aconselhador em relação à sua saúde.

\subsubsection{Enfoque sobre as Práticas de Educação em Saúde Referentes à Prevenção das DST/Aids, à Adesão à TARV e ao Autocuidado}

Nesta categoria serão apresentadas as informações dadas pelos entrevistados sobre o reforço das orientações preventivas a respeito de práticas sexuais seguras, sobre locais de tratamento acessíveis a eles e sobre os efeitos do aconselhamento no 
sentido de ativar seus recursos psicológicos. Essas informações visam o autocuidado para o aumento da sobrevida. Para não identificar os serviços de referência, eles serão designados genericamente pela sua sigla $\mathrm{SAE}$, independentemente de funcionarem como SAE (Serviço de Atendimento em DST/Aids), ou como CR (Centro de Referência em DST/Aids). A diferença na nomenclatura especifica os níveis de complexidade e de recursos diferenciados nos dois tipos de serviço.

A partir deste tópico, os dados serão apresentados não mais pela seqüência cronológica das entrevistas, mas de forma a dar mais mobilidade aos relatos dos clientes, relacionando-os pela sua semelhança e pela sua diferença quanto aos aspectos envolvidos. A análise poderá ficar um pouco mais dinâmica. Assim, à lógica diacrônica adotada até então, serão adicionadas as disposições sincrônicas próprias de uma análise estrutural.

Os dois CTA possuem sistemas de referência e contra-referência (forma de encaminhar o cliente nas várias instâncias do SUS) distintos. Em um dos CTA as consultas no serviço de assistência são agendadas pelo próprio CTA para agilizar a inclusão e adesão do cliente. No outro, o cliente define em qual unidade quer ser atendido e é encaminhado a ela. O agendamento da consulta fica sob sua responsabilidade.

Muitas questões feitas pelos clientes durante o aconselhamento dizem respeito aos efeitos causados pelo vírus HIV no organismo e à especificidade dos exames e tratamentos que serão necessários. Algumas vezes eles foram orientados a tirar essas dúvidas no outro serviço com o próprio médico ou outro profissional, conforme o caso. Outras vezes, o próprio aconselhador as esclareceu.

Sílvio relata que fez uma pergunta para a aconselhadora a respeito do momento em que se infectou:

“É, eu cheguei a fazer essa pergunta pra ela, se teria como saber a data, a época, né? [E se isso foi] Constatado pelo exame. Ela falou que não, que não dá pra saber."

Ele teve também outras dúvidas que esperava poder solucionar com os médicos do serviço de referência.

"Ainda coloquei alguma coisa. Falei: 'acho que vou ter mais coisas pra 
perguntar para os médicos'... Quando ela falou para eu tomar comprimido para controle, e isso, né. Eu falei assim: 'vou ter que perguntar mais coisas pros médicos'."

Para tirar suas dúvidas, esbarra novamente na questão da aconselhadora ser mulher e isso se alia à timidez que o retrai em relação à obtenção de espaços de interlocução e negociação, dificultando sua busca por esclarecimentos. De certa forma, estas barreiras tornam Sílvio mais vulnerável em relação à infecção e em fazer uso de práticas preventivas.

“... talvez eu possa me abrir mais com os médicos, que às vezes a gente pode ficar com timidez porque é mulher, né. Então a gente é baiano, é nordestino, fica com timidez de se abrir, né. De perguntar... Tanto que a própria timidez já vem do uso da camisinha. [Refere-se à dificuldade de propor o uso da camisinha para a parceira sexual]. Já vem, porque você vai ficar com uma mulher e pensa: 'ah, não vou usar isso não'. Fica com timidez, então por isso que acontecem essas coisas. [Está falando da infecção] A vergonha, a timidez, então, tem muita gente assim... Não sou só eu. Tem muita gente que, por timidez, vai acabar arrumando um problema."

Insere-se agora o relato de Milton referente às informações de prevenção e cuidado. Este entrevistado considerou curto o tempo de aconselhamento para todas as orientações e aspectos que têm que ser abordados. Em sua opinião, o portador do HIV deveria receber informações adicionais.

"Eu penso assim, quanto mais informações eles derem para o aconselhado, o portador... Melhor vai ser. Quanto mais eles chegarem e tirar toda dúvida, se possível fazer um folhetinho, explicando alguma coisa, como a pessoa deve se portar, assim, se passasse alguma coisa de alimentação, ficaria legal, também”.

Indagado sobre o que conteria o folheto, respondeu:

“Assim, como a pessoa deve se cuidar melhor. Por exemplo, você está com o vírus: alguns conselhos para a pessoa se cuidar, cuidar do parceiro, se caso tiver... [parceiro] (...) Cuidados com ele mesmo... Cuidados com relação à alimentação... Tudo. Essas coisas. (...) Só se alguém vem pegar o resultado e acabou. Em vez de ficar dando tanta informação, escreve alguma coisa. Ficaria legal! Acho que assim, a pessoa ia ficar bem melhor. Acho que na hora, não ia ter cabeça pra isso dependendo da reação da pessoa, não teria cabeça..." 
Com essa sugestão, Milton está propondo um encurtamento do tempo para dar informações adicionais, enfocando a questão de "não ter cabeça" para tanta informação na hora desta notícia. Considera que se a pessoa estiver muito angustiada, não atentará para as informações que depois lhe serão essenciais para o cuidado à saúde. Por isso a proposta do folheto que ele faz. Essa é também uma indicação de como foi difícil para ele estar ali ouvindo a aconselhadora, talvez por isso a necessidade de diminuir esse tempo.

GALANT (2004) publicou um artigo sobre as normas revisadas para a testagem, aconselhamento e referência ao HIV, de 2001, do Centro de Controle de Doenças (CDC) de Atlanta (EUA). A partir dessas normas foi elaborado um handout contendo informações para diminuir o risco de infecção pelo HIV, e recursos disponíveis para atendimento, respeitando a cultura, linguagem, sexo, orientação sexual, idade e nível educacional. Este trabalho parece ir na mesma direção do que este entrevistado propõe, com a diferença de que Milton adicionaria informações gerais de saúde, não só as relacionadas à prevenção do HIV.

Como já foi mostrado na citação anterior de seu relato, este foi um entrevistado que revelou já estar esperando o resultado positivo e, por essa razão, “não ter se abalado". Mas, na seqüência de sua entrevista, mostrou como o momento pode ser angustiante, a ponto de não se apreender todas as informações fornecidas no aconselhamento.

Nei, o entrevistado seguinte, não só se abala como sai "atordoado" pelo anúncio de que está com a doença que sabe ser incurável. E indaga:

"Você acha que com o passar do tempo, vai ter cura? Você acha que tem possibilidade de ter cura, a aids?"

Essa é uma pergunta, dentre outras feitas por Nei à pesquisadora. Isso sugere que ele não havia formulado todas as questões até aquele momento. E outras surgirão com o tempo e com a evolução do tratamento. Apesar das dúvidas que podem permanecer, Nei parece ter obtido uma compreensão a respeito da necessidade de se cuidar, apresentando sua própria convicção com relação a isso:

“(...) A gente tem que se cuidar e muito! Porque mesmo se a gente está com o vírus, a gente tem que se cuidar mesmo. (...) De repente, sei lá, 
você pega outra doença aí... Complica mais ainda, né? Tem que se cuidar e muito. Eu, se eu não me cuidei até saber, de agora para frente eu vou me cuidar, e muito! Porque tem gente que não tá nem aí, assim, 'já estou contaminado, então não vou me cuidar e [fala um palavrão] os outros', desculpe a expressão. Mas eu não quero isso para mim, de maneira alguma. O que eu não queria para mim, não quero para os outros, de maneira alguma. Então, o que eu puder fazer para não passar para as outras pessoas, vou fazer. Jamais eu iria gostar se alguém fizesse isso comigo, então, da mesma forma eu não vou estar passando para os outros."

Indagado se na comunicação do seu resultado a aconselhadora falou sobre isso, responde:

“É, falou. Que eu posso pegar outra carga viral e outras doenças também."

Como falou Nei, Cássio fala também sobre a cura da aids. É otimista e tem esperança. Considera que haverá um dia em que será possível a cura para a aids. Tendo mais idade, apresenta também mais complacência para lidar com seu primeiro resultado de teste HIV positivo. Ainda não havia feito o exame confirmatório, então ainda esperava um resultado negativo. Diz:

"Eu, de minha parte, fui bem atendido. A moça foi atenciosa e teve paciência. Apesar de que eu já estou [com o vírus], como ela deu o resultado, eu estou preocupado, mas sossegado, sabe por quê? Porque, de qualquer maneira é importante a pessoa saber sobre sua saúde, né, saber a segurança que ela pode ter, se mais adiante... mais no futuro, né? E se é uma coisa que pode ser curada, ou pode ser, como é que fala? Pelo menos controlada, né, melhor ainda, porque a pessoa vai ter um tratamento, vai fazer meio que ele possa sobreviver até o tempo que for necessário, né?"

Como ainda ia fazer o teste confirmatório, Cássio tinha esperança em ter um resultado negativo, mas mesmo assim recebeu algumas informações sobre prevenção e cuidado, como se observa em sua fala:

“É, primeiro ela pediu para fazer mais um. Pode ser que Deus abençoe e pode ser que dá até negativo. É ou não é? Agora, se der positivo de novo, a gente vai ter que..., vai ter que contar com vocês aí, para se prevenir, ter mais cuidado com isso ou com aquilo, procurar evitar. (...) Sim, ela me informou [sobre como se prevenir]. (...) Sobre tratamento também, 
porque esse novo exame que eu vou fazer, se der positivo, eu vou começar a ser tratado (...) no lugar adequado, né, que seja realmente... que possa dar toda a assistência necessária."

Tal como os entrevistados precedentes, Luís pretende continuar a se prevenir e a evitar a transmissão da doença:

"Eu penso, eu penso agora em viver; não chorar o leite derramado [risos] e viver, tocar a vida pra frente; me cuidar bastante, e evitar passar o vírus."

E também recebeu as informações nesse âmbito, de forma a melhorar o conhecimento que já possuía:

"Recebi. Pra mim foi uma coisa assim que clareou mais ainda, entendeu? Porque esse mal que eu estou com ele, eu não quero passar pra ninguém, jamais. Não quero dividir com ninguém..."

E sobre práticas sexuais desprotegidas:

"É, muitas coisas assim mesmo que eu (...) ela perguntou pra mim se eu fazia alguma coisa oral sem camisinha. Eu falei assim 'isso já existiu, né, só que hoje eu não tenho mais coragem de fazer'. 'De uns oito meses para cá, eu não tenho mais coragem de fazer'. Ela falou assim 'não, tudo bem, isso aí é uma coisa que, você já tem uma consciência do que isso hoje pode' [ocasionar]".

Em seguida, confirma que fazia sexo oral sem preservativo e que não o faz mais há algum tempo, tendo obtido o reforço sobre o risco desta prática durante o seu aconselhamento. Recebeu, ainda, a informação sobre a necessidade de comparecer ao outro serviço que vai avaliar a sua carga viral e o momento de iniciar tratamento.

“(...) Se eu tenho que ter essa carga, eu vou ter que carregar ela; eu não vou dividi-la com ninguém, entendeu? E se eu tiver muito, [refere-se à carga viral] geralmente, eu quero ver o resultado disso, como é que está primeiro, pra eu chegar a esse medicamento, e tal. Porque agora vai fazer esses exames pra semana que eu vou passar no médico. Então [depois] encaminhar pra ver a quantidade que tá pra mim. Ver, baseado nisso, o que eu vou fazer. Isso tá me preocupando também porque (...), eu acho que tá demorando."

Faltava quinze dias para a consulta no outro serviço. Sentia que era um tempo longo demais para esperar: "É, eu tô sentindo que é muito longo." 
Luís não achou difícil passar do CTA para o SAE. O que favoreceu sua aceitação de ir a outra unidade foi a maneira esclarecida de encaminhar e explicar os motivos disso:

"Não, porque eu acho que assim eles já me passaram pra lá é porque lá vai ter mais, entendeu, um avanço maior. É como ela me explicou: eu vou fazer outros, série de bateria de exames que eu também nem imagino que exames são esses, né, que ela me explicou porque é difícil explicar, né. Ela falou 'todo tipo de exame você vai fazer lá... Mais rigoroso', entendeu?"

O avanço nos recursos do serviço apontado por Luís será realmente importante, uma vez que ele já apresenta sintomas que, algumas vezes, o prejudicam no desempenho de atividades sociais e de trabalho. Dessa forma, o seu ingresso na unidade de tratamento será providencial.

Já para Juvenal, a ida para outro tipo de serviço oferece-lhe a chance de tirar dúvidas sobre a doença, que surgem a cada dia. Ele salienta que as informações que recebeu sobre a prevenção de DST/Aids são muito importantes, pois elas fortalecem sua intenção de negociação de práticas sexuais protegidas, uma coisa difícil de concretizar na relação amorosa.

"É aquela coisa, né... o coração, na vida a dois, você... Tem coisa que você tá consciente (...) que você tem risco. (...) Talvez até seja empolgação e tal, então... (...) Acho que o prazer é o mesmo, não impede em nada, o que vale mesmo é a vontade entre as duas pessoas, você nunca combina, você quer [usar preservativo] a outra não quer, então... Às vezes tá precisando fazer a vontade da outra... [O sexo consensual] Porque quer romper [o relacionamento], coisa e tal...."

Ele constata que não é fácil o convencimento do outro e o enfrentamento de sua má intenção, que por vezes acompanham os relacionamentos. Ele mostra a partir de que experiência pensou sobre isso:

"É sim... Às vezes você não tá [infectado], mas a pessoa tá... E a pessoa tá com maldade. (...) Assim: pensou se essa pessoa... Fica tanto tempo insistindo pra não usar, não vou usar, não vou usar... Ela tá com raiva mesmo e está com segunda intenção. Ela sabe que tá com o problema e quer passar pra frente, né.(...) Tem que ir lá e sair fora, desistir... (...) Você tem que pensar primeiro em você, né? Tem que pensar no seu bem- 
estar, senão... (...) a pessoa tem de ser bem firme, né... Bem firme naquilo que você quer e pensa."

Diante dessas dificuldades apontadas por Juvenal, pode-se indagar: o que fazer para essas informações serem praticadas pelas pessoas? Haveria uma forma de facilitar que essas pessoas que recebem informações nos serviços pudessem praticar mais essas informações de prevenção? Tendo experimentado a situação, Juvenal sugere:

"Tem de ter muita conversa, não é? Tem de conversar bastante, é... Para as duas partes serem convencidas, não é? Então, é negociar mesmo”!

E ele se sente com mais força para fazer isso daqui pra frente, o aconselhamento contribuiu para essa atitude...

"Porque eles te dão toda uma orientação, cada hora que você praticar, você põe em prática aquilo que você aprendeu aqui, aquilo que lhe foi passado, né... E... ajuda bastante..."

Como Juvenal, Arnaldo recebeu várias informações no aconselhamento. Dentre elas, refere ter recebido orientação no sentido de levar uma vida saudável e aprendeu com a aconselhadora a diferença entre ter o vírus e ter a doença. No dia da revelação do seu diagnóstico foram também retomadas as informações recebidas por ele no aconselhamento pré-teste (coletivo), como conta:

“(...) eu perguntei pra ela uma diferença da doença para o vírus; ela me fez assim um relatório assim, que eu nem posso dizer que foi... É... Como diria, resumido, foi bem prolongado. Ela me explicou direitinho, me explicou também sobre outras doenças que tem, doenças oportunistas, essas coisas assim. É... Ela abriu minha mente pra uma coisa que tava totalmente fechada, né. E eu estou aprendendo a lidar com isso. E eu saí daqui sabendo que eu não tinha passado por uma profissional simplesmente, eu tinha deixado para trás, eu digo, uma amiga porque ela acabou se tornando minha amiga porque o primeiro contato foi com ela $\mathrm{e}$ ficamos, assim, amigos. Porque eu acho que agora eu preciso realmente disso."

Ele recebeu o encaminhamento para o serviço de referência mais próximo de sua residência, mas estava receoso de encontrar, ali, pessoas de sua vizinhança, conhecidos seus, que pudessem tomar conhecimento do seu diagnóstico. Mostra um pouco de pesar por ter que ir para outro serviço que considera mais devassado. 
"É um lugar aberto, tem muita gente vendo a gente. Então não tem aquele, aquela intimidade, aquela... Separação que tem aqui... (...) Aqui a coisa é mais discreta; gostei mais daqui do que lá. [na unidade de assistência em DST/Aids] (...) Você fica público; todo mundo vai saber, sua vizinhança e volta aquele assunto que eu falei.... Da discriminação. Porque não é todo mundo que senta perto de um aidético no ônibus e não é todo mundo que toma um gole d'água ou de cerveja no mesmo copo... Não é todo mundo que compartilha as mesmas roupas. O círculo de amizade fecha, entendeu? Então, o meu medo é esse, porque a partir do momento que o seu círculo de amizade, sua convivência vai se fechando, você vai viver num mundinho pequenininho só seu, você acaba tendo depressão, entendeu? Então, eu acho que eu deveria ir pra um lugar mais discreto... Como aqui. (...) No lugar que vão te atender são três pessoas e uma fila enorme atrás de você... Aqui não. Aqui quando você chega, te chamam pra uma sala e conversam com você. Tá vendo aquela sala [aponta]? Você sai daquela sala tranqüilo, você sabe que ali você está protegido. E lá eu não sinto proteção nenhuma, não tem nenhuma proteção da sua identidade; você está exposto a todos... Aqui é muito bom; aqui é quietinho, ninguém fica sabendo de nada. Mas lá, não. Tanto é que eu tenho medo de ir naquele lugar, ali eu tenho medo. (...) Me fala o seguinte: nos postos, tem esse tratamento?

A materialidade é o que dá lugar ao setting. Para constituir o espaço compartilhado e sustentado, os gestores e os profissionais devem cuidar desse aspecto. A conseqüência esperada pelo cuidado a esse aspecto é que possa haver o desenvolvimento no cliente da confiança e do sentido de proteção.

Pode-se perceber no relato de Arnaldo que ele teve um bom acolhimento e sigilo preservado no seu atendimento no CTA. Por outro lado, o receio da perda do seu direito ao segredo no SAE pode ser entendido também como um sinal de sua dificuldade de tornar pública a sua condição soropositiva. É uma pista para que os serviços se dediquem mais ao trabalho direcionado aos sentimentos ligados à construção da identidade que se vê alterada pelo resultado do teste. Essa alteração parece estar diretamente ligada ao sentimento de Arnaldo de que está ameaçado de viver situações estigmatizantes, caso seu resultado positivo seja conhecido por outras pessoas. Ele próprio parece estar vivendo (e sofrendo) internamente a própria estigmatização. E receia que isso se exteriorize, ou seja, que outros o estigmatizem quando conhecerem sua soropositividade. 
Cabe então aos serviços cuidar deste aspecto, a princípio apontado por Arnaldo como material e concreto, mas que se revela como produtor de uma situação subjetiva de muito sofrimento. A ausência desse trabalho pode prejudicar o início e continuidade do tratamento recomendado para cada caso.

Dando prosseguimento aos relatos.

No momento da entrevista de pesquisa, Evandro e Paulo já haviam entrado em contato com os respectivos serviços de assistência em DST/Aids, os mais próximos de suas residências. Evandro julgou que estava preparado, por meio do aconselhamento, para receber o acompanhamento e cuidados médicos. Na unidade onde isso seria feito, passou por uma equipe de acolhimento e agendou consulta com o médico infectologista. No entanto, Paulo recebeu a informação de que teria que pegar uma senha para ser atendido no primeiro dia, o que o deixou preocupado com o acolhimento na nova unidade.

"Agora eu vou passar pela triagem, porque foi o lugar que eu marquei e liguei e a moça falou pra eu chegar às sete horas pra pegar uma senha. (...) E eu perguntei: 'tem muita gente?' E ela falou: 'é'. Sabe o que eu fico pensando? Se eu chegar lá, se realmente vai funcionar. Eu não sei se funciona esse órgão [público]. (...) Porque o meu medo é de começar outras coisas e tornar aquela demora, aquele descaso total, que em alguns órgãos existe. Que a mídia diz que funciona, mas não funciona. Eu vou lá, mas se não funcionar eu não volto mais. (...) eu fíco tão preocupado com esses órgãos públicos; existe gente que trabalha e gente que não trabalha. Só que, assim, se for pra poder virar especulação, pra eu ser mais um número, eu vou ficar bem irado. Se for pra levar à sério, eu estou lá pra levar à sério, eu vou topar qualquer prova, mas tem que ser respeitado, principalmente numa situação dessa."

A integração entre os serviços e o conhecimento de suas rotinas de atendimento é necessária para minimizar esse tipo de preocupação sentida por Paulo. A integração melhora também a transmissão desse tipo de informação no aconselhamento. Assim, ao sair do CTA com seu encaminhamento, o cliente poderia sentir mais segurança, favorecendo a adesão ao tratamento recomendado no seu caso. O contrário disso pode funcionar como impedimento ou obstáculo ao tratamento, como sinalizou Paulo. 
$\mathrm{Na}$ primeira entrevista de pesquisa, Paulo não havia realizado o exame confirmatório ainda, e mostrou que não the foi explicado suficientemente quais as razões da repetição do exame, e nem qual era a probabilidade de dar um resultado negativo. Isso o deixou inseguro e com incerteza quanto às condutas profissionais, como mostra:

“... quando ela falou pra mim do Elisa, que eu já conhecia de ouvir falar, dizem que o Elisa é muito eficaz. O Western Blot não conheço, me corrige se eu tiver errado porque a palavra é inglesa, é a confirmação do exame. (...) O que me deixou em dúvida é por que fazer a segunda coleta?* Por que fazer? É isso que eu não entendi. Por que fazer a segunda coleta? O exame não é eficaz, por que mais uma coleta? É mais um exame pra confirmar? Eu estou conversando contigo aqui, mas na esperança que na segunda coleta dê negativo. Mas se eu der negativo, você já registrou de como eu senti um positivo porque, até o momento, eu me sinto positivo."

Paulo incomoda-se também pelas perguntas feitas (Formulário de Atendimento dos CTA, com modelo no Anexo 3), associadas à necessidade de prevenção e oferta de preservativos. As perguntas desse formulário são fundamentais para o registro dos dados epidemiológicos necessários ao monitoramento da epidemia. A oferta de preservativos é importante para a adoção de práticas preventivas. No entanto, trata-se de procedimentos que, para respeitar a singularidade e o sofrimento do momento, precisam ser administrados de forma delicada. Vários entrevistados apontam o seu desconforto na situação: Pedro, Luís, Omar, e Paulo, cuja fala ilustra o que foi dito:

“... foi perguntado se eu tinha alguma dúvida [sobre prevenção] depois do fichário e do questionário. Quantos parceiros eu tive nos últimos dez anos. Quantas camisinhas eu queria pegar eu achei isso uma frieza impres-sio-nan-te [frisa as sílabas], porque quem tá aqui [aponta o seu lado na mesa], tá desesperado. Quem tá aí [aponta o lado do pesquisador] é um profissional, então eu achei isso de uma frieza... Não que o

\footnotetext{
* A explicação oficial dada para o método diagnóstico é: "O resultado desse teste [Elisa] é rápido, mas, ocasionalmente, pode surgir um falso positivo (resultado positivo para o HIV, em uma pessoa não contaminada pelo vírus). Por isso, caso o resultado seja positivo, aconselha-se repetir o Elisa e, em seguida, fazer o teste de Western Blot para que não restem quaisquer dúvidas. O teste de Western Blot é mais sensível e define, com mais precisão, a presença de anticorpos anti-HIV no sangue. No entanto, como é mais complicado e exige condições técnicas mais avançadas, só é utilizado como confirmação do Elisa.” (MINISTÉRIO DA SAÚDE 2005)
} 
profissional tenha que, não vai se envolver emocionalmente com o paciente, que isso não existe, mas quem tá aí, tá muito preparado. Estudou pra isso! Quem tá aqui está acabado, está destroçado. Então houve o questionário e, o que me deixou surpreso, não vou me lembrar dos últimos dez anos... De quantas pessoas eu tive, de quantos parceiros fixos... Quantas camisinhas eu vou pegar... Eu até falei assim pra pessoa: 'ah, dez camisinhas' e ela falou assim: 'só isso?' Eu falei: ‘só'. Então não tem mais onde se resolver. Depois de um resultado desse, na hora... Eu ainda não acordei, [nome da pesquisadora]. Você não pensa em nada. Também é indiferente se eu levar vinte camisinhas ou não pegar. Assim mesmo, não interessa! Não tenho contato sexual, não tenho vontade de fazer nada. Eu só quero saber como eu vou lidar com isso ainda. Eu conheço pessoas que estão vivendo normal, mas eu quero saber como eu vou sair disso sozinho. Sozinho, eu vou sair disso. Então, pra mim é indiferente pegar camisinhas lá embaixo. Eu não tenho vida sexual no momento. Por acaso ela tomou conhecimento disso? Zerou tudo!"

Diante dessa percepção, o efeito sobre o cliente poderia causar dano no sentido da (não) ativação dos seus recursos internos para o enfrentamento do diagnóstico e do desejo de cuidar da saúde. No entanto, Paulo possuía uma boa capacidade defensiva e, além disso, teve a oportunidade do segundo aconselhamento com outra profissional. Esta aconselhadora possibilitou a instauração de uma nova relação afetiva (ou transferencial, nos termos psicanalíticos). Paulo vem para a segunda entrevista da pesquisa com mais integridade psíquica, já pensando em sua vida futura, como se observa no próximo relato:

"[A aconselhadora] conversou sobre as dúvidas que eu tinha. (...) A qual procedimento daqui pra frente. (...) Onde me encaminhar. (...) Ela me deu a relação de locais próximos ao meu bairro e... Também tirei algumas dúvidas, né, perguntei sobre reações de medicação, dependendo do indivíduo, dúvidas, né. Se eu começar o tratamento, o que que vai acontecer comigo? Então, algumas coisas ela disse 'depende muito de cada pessoa, cada um tem um organismo diferente, cada um tem uma reação diferente', entendeu? E, e foi isso!"

Neste dia, Paulo refere que a aconselhadora retomou as orientações sobre a importância de continuar a se prevenir e sobre a ação do vírus.

"Ela me deixou bem à vontade, né, mas ela perguntou se eu queria falar 
alguma coisa (...) Pra eu tomar cuidado com algumas coisas e me esclareceu (...) sobre o vírus, mas de repente, meu sistema imunológico está bem, eu preciso passar numa triagem pra fazer exames pra saber como que estão minhas defesas. E também eu sei que todo cuidado quando tiver contato com outras pessoas porque, de repente, se você está com o sistema mais fraco, você adquire outras coisas. (...) A gente sempre acha que quando você ouve ou lê alguma coisa, você tá lendo e pensa que com você é diferente. Então, eu sabia sim, acho que inconscientemente. Mas, foi importante isso... Porque pra mim já levantou uma barreira do contato físico. Eu não sei, ela falou pra mim que eu ia superar: 'você supera'. Eu não sei se eu posso, pode até ser que isso aconteça, de repente, é uma coisa recente comigo. Ela me deixou explicado na minha cabeça. Quando ela percebeu que eu estava assim meio assustado, ela foi uma pessoa que conversou, assim, pra esclarecer mesmo, bem light mesmo..."

Como se observou, Paulo não se sentiu mais tão "destroçado". Havia esperança após este outro aconselhamento.

Os outros entrevistados, ainda não mencionados, apresentaram uma característica diferente quanto ao encaminhamento.

Começando com Mário, que faz a opção por ser encaminhado para o local onde seu parceiro já se trata (não é um serviço da rede municipal de assistência). Ele quer estar com o parceiro nesta empreitada. Como Paulo, ele percebe a diferença de enfoque quanto às informações que constaram nos dois aconselhamentos dos quais participou:

"Da primeira vez, ela falou para eu fazer outro exame. Eu fiz o exame. E agora, [no segundo resultado] ela usou outras palavras: ela falou para prevenir, para cuidar. Ela falou que agora preciso tomar cuidado, mas para não ficar com isso na cabeça. Foi um baque, como ela falou, mas... Para me tratar o mais rápido possível. Como meu parceiro está num lugar, então eu pedi para ela se ela pode me encaminhar para esse mesmo lugar dele [a mesma instituição de tratamento]. (...) Para eu ir com ele eu fico mais seguro."

E assim foi feito. Mário resolveu algumas dúvidas que possuía, mas outras ainda o inquietam:

"Acho que dúvidas a gente sempre tem, né. Com os primeiros 
resultados... tem que fazer mais outros para ver [outros exames] (...) É, porque pra mim o que eu tinha feito para contrair isso? De tão grave assim? Eu até hoje não consigo encontrar. Cada caso é um caso. Um é diferente do outro, mas tem gente que faz cada coisa! E não tem [o HIV]. Eu não fiz praticamente nada... Para merecer isso, sei lá."

Bruno não tem dúvida alguma sobre a sua situação infectante, nem tampouco sobre as formas de prevenção, como conta a seguir. Bruno é travesti e trabalha na rua à noite. Mas não foi por meio desta atividade que se infectou, como conta:

"Eu sempre soube que sexo é com camisinha, entendeu? Não tenho dúvidas quanto a isso. A camisinha, ela não tem perigo de estourar. $\mathrm{O}$ erro dela é ela ser mal colocada, (...). Eu também trabalho na rua à noite. (...) Só que não foi na rua. Não foi com o meu trabalho que eu peguei isso, entendeu? Foi uma fase de diversão. Não foi aqui em São Paulo também, foi em Minas, entendeu? No período que eu estava lá. Que eu tenho certeza que foi lá. Porque lá eu fiz coisa, você entendeu? Mesmo! Porque sabe, às vezes a gente bebe um pouco demais e aí, na hora você não quer nem saber dos riscos, né? Foi ai que eu me ferrei, entendeu? (...) Porque às vezes as pessoas podem, é, tipo rotular o meu trabalho, relacionar o meu trabalho com isso. Não tem nada a ver. Não foi no meu trabalho que eu peguei isso, entendeu? Pelo fato de eu trabalhar a noite. Não foi! Foi num momento de prazer mesmo, de loucura, sei lá. Eu não sei. Acho que eu bebi demais. Porque eu nem bebo bebida alcoólica. É muito difícil eu beber, e nas poucas vezes que eu bebi... E foi assim mais ou menos que aconteceu lá em Minas, isso. Que eu imagino que eu tenha pegado lá. Tenho certeza que não foi aqui em São Paulo, entendeu?"

Mesmo não tendo dúvidas, Bruno considera que se as tivesse, teria sido possível esclarecê-las no espaço do aconselhamento. A sensação de aceitação que Bruno sentiu ao ser aconselhado parece se confirmar pelo modo como pôde relembrar da situação infectante e por poder expor que é trabalhador do sexo, mesmo tendo apontado sutilmente o preconceito que às vezes percebe nas pessoas. Pode-se depreender também de sua fala o quanto de subjetividade está presente na prevenção do HIV. Bruno tinha plena consciência do risco que corria em suas práticas sexuais como trabalhador do sexo, demonstrando poder de negociação e atenção às regras de proteção, mas na relação afetiva parece se distanciar do saber internalizado, deixando-o "de fora", não o adotando. 
Trazendo agora a experiência de aconselhamento de Omar. Em função dessa ter sido negativa, Omar conta que não estava com disponibilidade interna para assimilar mais informações sobre prevenção, ainda mais tendo que passar por todos os procedimentos laboratoriais acarretados pela sua aceitação em participar da pesquisa do "detuned", já mencionada. Havia um excesso de informações e uma carência de espaço intersubjetivo. Mesmo assim, concordou em participar de ambas as pesquisas.

“... Legal, eu vou falar sobre isso. É um batalhão... de papéis e tal, e você se sente assim, né? É... O que poderia acontecer? O inverso... 'Não, não vou fazer nada, acabou. É esse o resultado? E esse o resultado!' Se eu não tivesse preparado pra receber essa informação, na segunda vez da confirmação, eu não ia participar dessa entrevista, eu não ia pra [instituição que realiza a pesquisa do detuned], não ia fazer nada. Por quê? É o sentimento e tudo mais. É muito papel. Você fica assim: 'meu Deus!... tá, beleza!'. E aí começa a ler. Assim, você lê, mas você não lê nada. Né? Você fica... , tem que fazer isso e tal. Aí tem que colher material e tem que fazer isso... E aí... Nossa, a realidade é outra agora, entendeu? Então, se você não está preparado pra isso, (...) Acaba não fazendo nada, né, você se fecha pra tudo isso, né, porque você pode ajudar as outras pessoas e bloqueia e ponto final. E aí eu sigo aí na rua aí, louco, 'faz de conta que não estou com nada' E... Ponto final! E vou levar minha vida normal. É esse o intuito? É. Esse o intuito? Não é o intuito, não é?"

O tom de sua fala é de indignação e de protesto contra a forma como foi atendido na situação de aconselhamento do primeiro teste. Essa experiência poderia ter prejudicado a sua participação nos dois estudos que o interessaram e aos quais daria sua colaboração. No entanto, Omar mostra que não se fechou totalmente. Existe uma necessidade de estreitar a ligação entre prevenção e assistência e isso só pode ser iniciado pelo aconselhamento. Assim, a qualidade de vínculo e de entendimento é o primeiro passo. A pesquisa (sobre infecção recente) garantia o tratamento, trazendo um beneficio para estes três clientes: Omar, Bruno e Jonas.

O que ocorreu com Bruno e Jonas foi diferente em relação à pesquisa. Bruno ainda estava no processo de coleta dos exames para a pesquisa laboratorial, não tendo concluído totalmente o processo. Mas não tinha pressa de ir a outro serviço, pois vinha ainda ao CTA para se orientar com a aconselhadora. No caso de Jonas, a 
participação naquela pesquisa foi considerada uma possibilidade de escolha e de garantia de atendimento de qualidade, aliada à colaboração para o desenvolvimento científico (que prezava).

"Ah, foi tranqüilo, ela perguntou para mim aonde eu queria estar me tratando, me cuidando. Assim, a princípio, eu achei o [fala o nome de um dos serviços de prevenção e assistência em DST/Aids] legal, porque é um lugar que eu conheço e que eu freqüentava antes [acompanhando amigos infectados]. Eu fui para lá. Mas depois, fiquei sabendo de um outro projeto que até é um projeto novo que está acontecendo na [instituição que realiza a pesquisa à qual aderiu] e eu estou lá nesse projeto agora. (...) Já vai fazer um mês. (...) Então, já fiz todos os exames e detectaram que foi um vírus de dois meses. (...) $\mathrm{E}$ assim, eu estou tendo um tratamento legal lá com os psicólogos, com o pessoal..."

A primeira indicação feita pela aconselhadora foi o serviço de referência mais perto da residência de Jonas, para onde ele se dirigiu inicialmente.

"...me indicaram o [nome do serviço de DST/Aids indicado] (...). E, sinceramente, eu achei o lugar meio negativo. (...) Cheguei a ir. Assim, o atendimento lá é totalmente precário. Eu vi que não iria me satisfazer como cidadão, sabe. Então, eu resolvi não ir para lá. Eu vi coisas que não me agradaram. Então, não foi legal. Não é porque a pessoa está positiva que ela deve estar naquele tratamento. Acho que as coisas poderiam ser um pouco melhores. Por mais que a saúde brasileira esteja, desculpa: [fala um palavrão], eu acho que poderia ser um pouco mais humano. E eu não me senti bem lá. Não por causa do sigilo, eu acho que não era o lugar que eu deveria estar."

Em pouco tempo, dois meses, como descreveu Jonas, ele passou por três serviços, tendo realizado exames laboratoriais em dois. Isso mostra uma agilidade no sistema de referência que lhe deu a oportunidade de uma escolha satisfatória e de acordo com a sua expectativa de um serviço bom. É importante ressaltar que, apesar de não ser objetivo do presente estudo a avaliação dos serviços, Jonas faz o próprio julgamento a respeito de um dos serviços de referência, que pode apontar uma razão para possíveis não adesões aos tratamentos. Mais acima, Arnaldo já havia criticado a estrutura deste mesmo serviço.

Apesar desses pontos negativos assinalados e das diferenças entre os aconselhamentos investigados, todas as narrativas apresentadas mostraram que os 
aspectos envolvidos nesta categoria de análise foram contemplados, em maior ou menor grau. As dificuldades parecem ter sido decorrentes de vínculo prejudicado entre a aconselhadora e o cliente, e de certo mal-estar provocado pela mudança de instituição assistencial. Embora reconheçam a complexidade requerida na seqüência do seu tratamento, a separação de um local de atendimento conhecido e acolhedor para outro desconhecido foi geradora de ansiedade para alguns entrevistados. Essas situações e dificuldades apontadas merecem ser mais bem apreciadas pelos serviços, tanto os CTA, como os SAE e CR.

Praticamente todos os entrevistados saíram da situação de aconselhamento com a convicção de continuarem praticando sexo seguro e desejando cuidar da saúde, seja levando uma vida com hábitos saudáveis, seja aderindo ao tratamento a ser recomendado em cada caso. Diante desses dados, pode-se supor que os objetivos analisados de reforçar as práticas preventivas, e de incentivar o tratamento e autocuidado, foram atingidos de forma satisfatória nos aconselhamentos investigados.

Como já se descreveu nas conceituações sobre o processo de aconselhamento, existem diversas recomendações feitas pelo Programa Nacional de DST/Aids. Essas recomendações dizem respeito aos conteúdos que devem ser abordados e que nem sempre é possível tratar de todos na comunicação do resultado positivo. Com base nisso, ao se prosseguir com a análise, se procurará verificar quais foram os aspectos mais freqüentes que surgiram, foram privilegiados e tratados pelos aconselhadores e aconselhados.

\subsubsection{Aspectos Privilegiados na Comunicação do Resultado Positivo.}

Esta categoria é inserida para evidenciar as informações mais acentuadas nos aconselhamentos realizados com os sujeitos de pesquisa. Alguns aspectos tiveram seu lugar destacado e, dada sua extensão e especificidade, cria-se uma subcategorização para uma melhor exposição e análise. As sub-categorias são: o preenchimento da ficha epidemiológica (Anexo 3), a superação das dificuldades em compartilhar a notícia a outrem e o oferecimento de outro horário de atendimento. 


\subsubsection{O Preenchimento da Ficha Epidemiológica (Anexo 3)}

Todos os entrevistados referiram-se às perguntas que são feitas de rotina. Estas perguntas têm a função de levantar os dados epidemiológicos imprescindíveis ao conhecimento do perfil da epidemia brasileira, a fim de programar ações destinadas ao combate e prevenção da aids.

Alguns consideraram desconfortável responder às perguntas, pois tinham que explorar a própria memória. Esse desconforto se associa ao fato de que remexer no passado de práticas sexuais (ou de outra ordem) provoca mal-estar em alguns entrevistados. Todavia, isso é necessário para buscar detalhes que possam caracterizar situações de risco de infecção pelo HIV.

A contabilidade relacionada ao uso de preservativo nas relações sexuais também foi abordada, tanto no que se refere ao uso já acontecido, quanto à oferta de uma quantidade deste insumo para as relações sexuais futuras. Para alguns, esse último aspecto pareceu fora de tempo e lugar, em função da sua paralisação de projetos amorosos naquele momento. É o caso de Pedro (impactado, ainda, pela perda do parceiro) e Paulo ("zerado" na atividade sexual pela descoberta da soropositividade).

Freqüentemente, a dinâmica estabelecida nos aconselhamentos causou a impressão, nos sujeitos, de que a tarefa obrigatória de preenchimento dos formulários era mais importante do que o reconhecimento de si mesmos como pessoas. Todavia, os entrevistados perceberam a necessidade de elaboração destes questionários.

O exemplo mais emblemático disso é o de Omar, cujo relato ilustra sua sensação a esse respeito:

"Ela foi anotando alguns dados, tal e aí você fica um pouco naquela apreensão, né? 'Dá logo, né? Já fala logo pra não ficar com rodeios.' Embora eu acho que... pra você dar uma noticia dessa, que eu sei que é complicado, você tem que... é... eu acho que tira um pouco da parte do administrativo, porque você tá lidando com uma pessoa. Depois que você deu a notícia, enfim, aí você vai cuidar da sua papelada. Entendeu? Sabe fica aquela coisa meio mecânica. Meio não, totalmente mecânica, né? Eu vim aqui, você que vai dar a noticia pra mim, certo? Então você tem algumas partes que você tem que preencher, né? Que faz parte do 
processo. É... só que antes de mais nada é uma pessoa que está ali, né? Então: 'oi, tudo bem?' E tal, né? Isso até foi, é... perguntado por uma questão de praxe, assim. Foi esse meu sentimento."

A "papelada" referida por Omar diz respeito ao levantamento de dados sobre a clientela e, de fato se compõe de muitas perguntas que requerem tempo e um pouco de esforço de memória para seu preenchimento. O modo como ele relata que the foram feitas as perguntas aumentou sua expectativa e ansiedade com relação ao resultado. Aumentou também a distância entre a aconselhadora e ele. Omar sentiu que aquilo era mais importante e presente do que ele, dando a impressão de que os aspectos formais e burocráticos da instituição eram os que tinham mais valor. A pessoa-ser humano-cliente parecia estar ausente, sem presença garantida.

No entanto, nem para todos os entrevistados o preenchimento do questionário e o aconselhamento em si pareceu dessa maneira. Nos casos de Milton e de Evandro, eles descrevem que a rotina utilizada não os incomodou, mesmo esse último tendo que lembrar de coisas de seu passado, o que considerou um pouco difícil:

Milton: "Bom, Eu liguei, né, pra saber do resultado, tudo, deram a data certa. Ah.! Eu não lembro agora quem me deu, o nome da moça, mas a gente conversou, né? Perguntou... Fez as perguntas de rotina, né? Se eu tinha parceiro fixo, essas coisas."

Evandro: "Acho que o que estão fazendo está certo. Preenchendo a ficha primeiro, vai dando tempo da pessoa se preparar. (...) Como eu me senti? Ah, eu me senti assim, que a gente tem que voltar tudo pra trás, ficar pensando no que a gente fez, tal, falar para a pessoa... Mas eu não me senti envergonhado de nada, não. (...) Ah, sempre é difícil você falar de coisas que você não está mais praticando. Você quer é esquecer..."

Esses relatos mostram que não existe uma única maneira de abordar o mesmo procedimento, uma vez que as pessoas são diferentes umas das outras. O que parece importar é o setting criado que se inicia desde o momento em que o cliente telefona para marcar o horário de aconselhamento (como apontou Milton).

\subsubsection{O Oferecimento de Outro Horário de Atendimento}

Os entrevistados referem que lhes foi oferecida a possibilidade de irem outras vezes conversar, caso precisassem, em ambos os serviços. No entanto, poucos fizeram 
uso desta possibilidade. Como já foi mostrado anteriormente (na categoria 4.2.2), muitas vezes a intenção de voltar estava obliterada pela indicação da continuidade de atendimento em outro serviço. A dificuldade para se dirigir a uma unidade de saúde desconhecida mesclava-se à intenção de ter um novo horário de aconselhamento.

O relato de Pedro ilustra bem isso:

"Eu até falei: 'eu vou pra lá, eu fui encaminhado para lá, mas eu posso visitar vocês de vez em quando?' [A aconselhadora] Falou: 'não, você pode sim, sem problema nenhum. Na hora que você quiser vir, é só marcar um horário...'

A frase de consentimento da aconselhadora expressa a possibilidade e a proposta de novos encontros. No entanto, existe uma ambigüidade presente, uma vez que Pedro, mesmo sentindo vontade de ir até o CTA para conversar, não o faz. Como em todos os outros casos do CTA, o cliente já é colocado a caminho da outra unidade de saúde onde fará seu tratamento. E assim, Pedro justifica não ter marcado outro horário para conversar:

“(...) Mas como já é recente ainda... E eu já fui encaminhado para lá [serviço de referência]. Em agosto eu vou ficar para lá, mas quando eu tiver meio ruim e quiser desabafar, conversar um pouco. Não sei se lá vai ter... Será que lá vai ter psicólogo, assistente social, alguma coisa que eu posso conversar?"

São tantas as dúvidas e indagações dos clientes, que torna-se difícil listar e referir todas elas nesta análise. Estas questões denotam a complexidade e a quantidade de informações a serem dadas em um encontro de aconselhamento. Por essa razão são privilegiadas algumas em cada aconselhamento, havendo que se dar preferência às mais pertinentes às necessidades de cada cliente naquele momento.

Essas considerações assinalam que o horário adicional pode ser imprescindível para aplacar a angústia da quantidade de informação a ser transmitida, tanto para o aconselhador, quanto para o cliente. Pode-se, ainda, fazer uma reflexão sobre formas para uma melhor efetivação do horário adicional oferecido. O cliente parece não se engajar, por ficar a meio caminho entre o CTA e o outro local de atendimento. Está em trânsito, ainda não chegou ao seu destino, mas já partiu do lugar de origem. Em síntese, o importante é que o espaço a mais de 
conversa possa ser melhor garantido.

\subsubsection{A Superação das Dificuldades em Compartilhar a Notícia a Outrem}

Essa sub-categoria inscreve-se também dentro dos objetivos do aconselhamento sorológico preconizados pelos manuais oficiais de treinamento do Ministério da Saúde. Torna-se relevante tratar dos aspectos que ela contempla. As dificuldades em compartilhar a informação de ser portador do HIV foi uma questão abordada pelos aconselhadores e privilegiada nos aconselhamentos. Trata-se de uma preocupação presente em vários casos.

Assim, boa parte dos entrevistados necessitava tratar, no seu aconselhamento, da questão do compartilhamento do seu status sorológico a terceiros, seja no ambiente familiar, seja no ambiente social ou de trabalho. Na entrevista de pesquisa, nem sempre se obteve a informação sobre este dado. Porém, o tema apareceu de forma diversificada para cada cliente entrevistado.

Nos casos de Sílvio, Evandro, Cássio e Milton, essa era uma questão essencial e preocupante. Não só pelo fato da divulgação da infecção em si, como também pela necessidade de propor aos parceiros que fizessem seu próprio teste antiHIV.

Mário já sabia que seu irmão e seu parceiro estavam infectados e a sua dificuldade de quebra do sigilo referia-se à família. Sua mãe desconhecia, inclusive, a situação sorológica do irmão de Mário.

Paulo, Pedro e Milton tentavam refletir sobre a melhor pessoa da família a quem dar a notícia, pois não tinham proximidade com todos os seu membros.

Luís e Juvenal, não tendo família em São Paulo, pensavam em quais seriam as pessoas de sua relação que poderiam se solidarizar com eles.

Nei sabia a quem e com quem contar, mas preocupava-se com a divulgação da notícia no trabalho, e a dificuldade com relação a esse ambiente também era a de Luís. O temor do preconceito existente e da discriminação que pudesse ocorrer era o sentimento predominante, e fator obstaculizante da comunicação da condição sorológica a outrem. 
Durante a entrevista de pesquisa, alguns sujeitos fizeram colocações quanto ao preconceito e quanto às dificuldades envolvidas na revelação de sua condição sorológica. Nota-se que o espaço dado para este tema na situação de aconselhamento variou em função da dupla aconselhador-aconselhado e das dificuldades de escuta e de formação de vínculo já apontadas. Ademais, é bastante variável a situação de relacionamentos afetivos dos entrevistados, o que determina a multiplicidade de enfoques e diversidade com respeito às questões levantadas, como se poderá observar.

Para uma melhor clareza, as abordagens da comunicação do diagnóstico aos parceiros, à família e na situação de trabalho serão expostas separadamente.

\section{Contar para o parceiro}

O aconselhamento de Sílvio esteve muito centrado na sua preocupação em como (e quem) revelar o diagnóstico às parceiras, pelo fato de ele possuir relação estável com duas mulheres ao mesmo tempo, como já foi apontado. Nesse caso, a ajuda das aconselhadoras foi fundamental para lidar com o problema:

“...elas [as aconselhadoras] falaram que se precisar de ajuda, elas vai ajudar. Tanto pra transmitir as conversas pras esposas, se for preciso falar. - 'você quer que eu falo? Eu falo pra você, a gente chama aqui e conversa '... Tanto que essa segunda aí, eu vou dar um jeito de ser falado [revelado o diagnóstico] por aqui, não comigo, porque acho que não vai ser correto eu falar. (...) Vai ser [difícil] sim, porque ela vai ficar brava. Acho que eu não vou tocar isso aí".

E ele levou mesmo as duas mulheres ao serviço, uma de cada vez, para fazer o teste:

“... eu trouxe a primeira, que eu estou com ela agora, que é a mãe dos meus três filhos. Eu trouxe ela e como ela é uma pessoa mais de idade, né, seria mais fácil a resposta pra ela. É que ela é mais entendida. A outra, até agora ela não sabe. Ela não sabe, eu não tive como ainda falar pra ela, tanto que eu falei com as meninas aqui [as aconselhadoras], se seria mais fácil elas mesmas falar. Porque ela é nova, então, nova e irritada, agitada, né. Agressiva, daqui a pouco vai falar que eu peguei da rua, ou que eu saí... É que uma fica jogando pra outra, né? (...) eu pedi pra ela [a aconselhadora] pra dar [o resultado] pra essa segunda (...). Pra 
mim não falar diretamente porque ela é muito nervosa, né?"

E isso foi feito no CTA. Sílvio convidou as mulheres a vir fazer o teste e teve dificuldades para manter o sigilo do seu resultado. Para propor o uso do preservativo, que não era utilizado pelo casal, também tem dificuldade.

Sílvio relata uma conversa que teve com uma de suas parceiras ao telefone e que ilustra, um pouco, a realidade vivida pela pessoa após receber o resultado positivo:

"Ela falou no telefone comigo. (...) eu liguei pra ela, chamando ela pra vir fazer o teste, né? (...) Não estou morando com ela, e eu liguei. Lá em casa não tem telefone. Então eu liguei pra ela e falei: 'olha, você vem aqui'. E quando eu recebi o resultado aqui [no CTA], já me deram os preservativos no primeiro resultado. Depois que me deram os preservativos eu fui lá, ficar com ela. E eu não usava camisinha, passei já a usar, e ela já estranhou. Ela estranhou, falou: 'oh, você vai usar?' Eu falei: 'não, vamos usar porque daqui pra frente a gente tem que ter um sexo seguro, né.' Eu vou saber... Ainda falei: 'você tá sozinha aqui? Eu não sei se você tá trazendo alguém.' E eu falei assim, né? (...) Aí ela ficou... Tudo bem ela usou... Eu usei, né? $\mathrm{Eu}$ usei e ficou aquilo na cabeça dela, e quando eu ligo pra ela e falo pra ela fazer o exame também, ela chegou, ficou falando... Os vizinhos lá lavando roupa, a mulher que lava roupa, que é vizinha dela. Ela começou falando: 'vem cá, porque é que você tá chamando eu pra fazer o exame, porque você tá com aids?' Eu: 'cala a boca, não fica falando essas coisas aí na vizinha, todo mundo tá escutando' [diminui o tom de voz imitando o tom que usou na conversa]. E ela: 'Ah, porque que você fica insistindo tanto que eu faça esse teste? Eu não tenho nada.' Eu falei: 'mas eu não tô falando que você tem, eu só tô falando pra você também vir fazer, pra se prevenir, pra ter uma certeza, realmente se você não tem nada'. [Explica para a pesquisadora:] Porque eu também não acharia que eu tinha nada, mas eu imaginando comigo, né. Eu também achava que eu não tinha nada e acabei tendo. Então eu também posso ter transmitido pra ela... 'Venha fazer que é bom'. Aí eu tinha comprado um cartão telefônico, 50 unidades eu acabei gastando as 50 unidades tudinho pra poder conquistar ela pra vir. E acabei conseguindo trazer ela. No dia que eu sai de lá pra trazer ela, a outra descobre que eu tô com ela. Aí já: 'ah você tá indo atrás dela, que não sei o que' eu falei: 'mas você tá sabendo que essa... [doença] Você também já foi fazer, ela também tem o direito de fazer. Eu preciso levar ela no posto pra fazer o exame.' Aí ela ficou nervosa 
também, discutiu comigo: 'ah então, se você... Já que você tá com isso, que foi pego dela vai embora contar a ela'. Eu falei: 'eu não posso acusar ela. Eu não posso acusar ela, eu não posso acusar você, porque afinal de contas, né, há seis anos atrás ou cinco anos atrás, que é essa doença e eu não tinha ela.' É, eu posso ter saído com outra e então eu não posso falar que foi a de casa, nem que foi lá. Entendeu?"

Era uma maneira, a maneira de Sílvio de dizer que teve outros relacionamentos fora da relação conjugal. Por meio de um deles contraiu o HIV. Contar que estava com o vírus significava contar que manteve relações extraconjugais. Talvez esse fosse o maior problema a ser enfrentado para dar essa notícia: admitir para as parceiras seus outros relacionamentos. No entanto, Silvio não se esquiva de enfrentar a dificuldade de se confrontar com elas. Se antes não tinha consciência do risco de infecção, agora parece não só tê-la adquirido como também tenta multiplicá-la ao convencer suas mulheres a ficar sabendo sobre seu estado sorológico.

Em um outro dia, a pesquisadora estava no CTA e o encontrou na sala de espera. Sílvio havia trazido suas duas mulheres: uma ia receber o resultado de seu teste. Havia uma discussão entre eles (os três), pois a primeira esposa queria ter conhecimento do resultado da segunda. O entrevistado pediu ajuda no sentido de convencer a primeira de que, se a segunda esposa não quisesse contar o seu resultado, ela não teria que fazê-lo. Foi sugerido que ele pedisse ajuda à aconselhadora, com a qual falaria a seguir. Sua dupla situação conjugal era complicada e se desdobrava em questões inusitadas para o CTA. Apesar disso, ele estava sendo acolhido pela equipe do serviço para tratar das dificuldades familiares decorrentes de seu resultado positivo. Isso era o que importava naquele momento. $\mathrm{O}$ oferecimento feito pela aconselhadora no dia da revelação do diagnóstico foi aceito e estava se efetivando. O novo e inédito estão sempre surgindo nas situações envolvendo os atendimentos nas unidades de saúde, e as respostas nem sempre estão à disposição, e nem sempre estão prontas. Às vezes é necessária a construção e reconstrução de modos de resolução das questões que se apresentam. É o que ilustra a situação de Sílvio.

Outro entrevistado, Milton, tinha um parceiro fixo desde três semanas antes da entrevista da pesquisa. Para ele, o tempo cronológico de três semanas 
representava, simbolicamente, um tempo de relacionamento muito maior. Milton dedicou-se, na segunda entrevista, a falar desse relacionamento amoroso e de como tinha medo de perdê-lo em conseqüência do seu resultado positivo. Estava muito contagiado pela emoção no momento da segunda entrevista da pesquisa. Ele, que contou que no dia da revelação do resultado estava muito tranqüilo, desta vez manifestou muita angústia. Pode-se perceber que está vivendo um momento de muito sofrimento, com muitas emoções. Dentre elas, expressa sentimentos ligados ao relacionamento amoroso que se misturam e abafam, em parte, os sentimentos ligados à soropositividade. Falar sobre o momento da comunicação do resultado parece estar sem lugar.

"Sim, eu não disse muita coisa, porque eu não estava abalado, eu tava bem. Agora é que eu penso que, pela primeira vez eu tenho um relacionamento assim, fixo e correspondido. Tive outro relacionamento fixo, mas não era correspondido, Eu me jogava nos pés dele e não recebia nada em troca. Agora é diferente. Sinto que também sou amado. E, agora, com o resultado positivo, não me sinto merecedor desta pessoa."

Apesar do medo de perder o companheiro, Milton não escondeu seu diagnóstico dele. Nem o escondeu dos amigos, de quem recebeu apoio, sendo, inclusive, acompanhado por eles ao CTA em uma das vezes que teve que retornar lá.

\section{Contar para outros familiares}

Com relação a esse aspecto, é Paulo que se angustia e considera necessária a abordagem desse tema no processo de aconselhamento:

“... Eu acho não, deve abordar porque, não só com as pessoas, mas acontece que você também tá sentindo ôh, eu estou bem, estou bem, tenho que me conformar com isso. Mas, até hoje, minha luta agora é saber para quem eu vou contar isso, quem é a primeira pessoa que eu vou falar isso. 'Olha gente, eu sou portador do HIV', entendeu? Mas, assim, eu não quero que se alarde isso. Quem da família eu vou falar isso? Por exemplo, eu poderia contar com uma pessoa, mas ela vai viajar agora. Eu não quero, eu quero que ela vá e volte e saiba. É uma pessoa tão sofredora que é a única pessoa que eu confio! Só que se eu for falar pra ela, eu tenho que falar: 'escuta, eu não quero que você comente nada com ninguém por enquanto', entendeu? Senão cria aquele auê todo. Eu não quero envolver a família, mas tem esse alguém que eu quero comentar, 
mas como é que eu vou comentar com essa pessoa? (...) Isso tem que ser trabalhado, eu acho. [Bate com o dedo na mesa várias vezes]. Quando eu sair daqui, eu vou sair sozinho, eu sei que eu vou continuar sozinho. Mas às vezes as conversas podem até ajudar um pouco."

Paulo reforça seu sentimento de solidão e tem consciência de que essa condição não será modificada no aconselhamento (como também observou Luís no ítem 4.2.1). Mas considera que se pode falar sobre ela. Pelo que Paulo se recorda, essas questões não foram trabalhadas no seu aconselhamento. Ele reflete:

"Negro, pobre, japonês, gente pobre ou não, gente ignorante ou não, tem nível superior ou não. Eu te disse isso na primeira e vou repetir: quem está aqui, está sozinho. Não traz pai, nem mãe, nem irmão. Depois vai passar todo aquele processo 'em quem vou confiar?' 'como que eu vou falar com um membro da família?' (...) por isso que eu acho que devia ter esses espaços [no serviço]. (...) Não sei se eu comentei ou pensei, mas eu acho que eu pensei 'com quem eu vou comentar?' Até hoje estou nessa tortura (...) Tanto que nesses espaços deveriam ser dados, ou pelo menos... Não estou te questionando também, se não foi dado. Eu também não perguntei, né, mas é uma coisa que precisa ser analisada."

\section{Contar no trabalho.}

Esse aspecto adquiriu bastante importância para os entrevistados que sentiram que seu emprego poderia estar ameaçado pela soropositividade de seus testes de HIV. Como já foi apresentado na caracterização dos voluntários no início deste capítulo, muitos estavam fora do mercado de trabalho formal e essa questão não se apresentou, como foi o caso de Sílvio, Milton, Evandro, Cássio, Pedro, Mário, Arnaldo e Jonas. Outros se sentiam, de certa forma, seguros em relação aos seus respectivos trabalhos, como era o caso de Paulo, Omar, Bruno e Juvenal. No entanto, para Nei e Luís, contar o resultado no local de trabalho era uma questão importante por razões diversas:

Nei saiu da entrevista de comunicação do resultado "atordoado", a ponto de não estar em condições de conversar com ninguém, mas pensava em revelar o diagnóstico para as pessoas da sua relação: sua irmã, seu tio (com quem mora), a quem pretendia contar logo. Achava mais complicado falar no trabalho, em função 
de estar trabalhando há apenas três meses e por já ter tido um colega que sofreu preconceito por parte dos colegas, por portar o HIV. A possibilidade de ser discriminado naquele ambiente preocupava-o, mas ele achava que pelo menos seu chefe imediato deveria saber, como se expressa:

"Eu nem vou falar nada lá agora, eu pretendo falar, pelo menos pro meu chefe, porque não quero assim... (...) Sei lá. Minha vida não é muito assim, eu não gosto de muito segredo. Para mim, assim, lógico que têm pessoas... Que você não vai, eu não acho que você vai sair botar uma placa na testa e sair gritando que está com aids, não é? Também não tem necessidade. Mas para algumas pessoas... Porque, queira ou não, vai ter um dia que eu vou ter que ir ao médico. Você passa no médico, o médico vai te mandar fazer exame de sangue. (...) Queira ou não um dia eles vão descobrir. Porque têm pessoas que vê falar de aids e tal, isso e aquilo, mas não sabe o que é, e de repente você fala... Vai sempre ter aquele preconceito, entendeu? (...) 'O cara tá com aids, né?'”

Na primeira parte da entrevista, Nei havia contado a respeito de um colega de trabalho que contraiu o vírus da aids e que ficou isolado pelos colegas. Aquilo que ele chama de preconceito (no relato acima) baseia-se na experiência vivida com esse colega:

“É, porque lá na firma esse rapaz, lá. (...) às vezes ninguém queria nem sentar perto dele, eu mesmo ficava morrendo de dó. Às vezes eu ia, eu conversava muito com ele. Eu sentava e conversava muito com ele. (...) Eu já sabia mais ou menos que: conversar, pegar na mão, não tem nada a ver, não pega. E às vezes o pessoal discriminava, assim, o pessoal, ninguém queria sentar perto dele, assim, para almoçar no restaurante por motivo da doença, né? Do vírus. (...) Até hoje, quando alguém vê alguém que tá com aids, fala: 'ah, ele é homossexual, é não sei o quê...' Mas isso não tem nada a ver, ela pega em qualquer pessoa, não é só de homossexual que pega a doença, lógico que não. Pode acontecer mais casos no meio sexual, né, no meio homossexual, mas não tem nada a ver isso aí, pega em qualquer pessoa... Desde que você não se cuide.”

Esse parecia ser também o tipo de preconceito que Nei pensava poder sofrer: o de ser considerado homossexual, mesmo não sendo. A quebra do sigilo de sua condição de estar soropositivo estava contaminada pelo duplo sentido que podia ter essa revelação, um verdadeiro e outro falso ou distorcido. Algo a mais para fazê-lo manter aquilo de que não gostava: o segredo. Mas ao mesmo tempo não desejava ser 
tratado de forma estigmatizante, como tinha sido o seu colega.

Todavia, Luís, esse já havia sofrido muito com o preconceito e a discriminação por ser homossexual. Freqüentemente, tinha que enfrentar as pessoas no local de trabalho para se fazer respeitar e, algumas vezes, de maneira agressiva. Enfrentava, ainda, problemas trabalhistas ligados a acidentes de trabalho que ainda não estavam devidamente resolvidos junto à previdência social. Em seu aconselhamento foi mencionada a possibilidade de procurar a assistente social do serviço de referência para orientá-lo quanto aos seus direitos por ser portador da doença. Isso foi importante porque ofereceu a Luís um caminho possível para resolver seu conflito. Não obstante, são muitas as suas inquietações com relação ao trabalho. Ele conta uma parte delas a seguir:

“... o homem que é homossexual, ele já é manjado, já é criticado e com a doença, que o meu medo é dentro da firma porque eu já fui muito criticado. Então eu já falei, eu já desci a mão no pé do ouvido dum cara que tinha lá dentro (...) Era 'viadinho pra lá, era viadinho pra cá'. E aquilo eu levava na brincadeira, mas chegou uma hora que não deu, entendeu? Começaram a passar a mão em mim, aí nesse dia, nove horas da manhã, (...) nós subimos pra tomar café, (...) tô tomando água, aí o cara chegou esfregando em mim 'aí viadinho, não sei o quê'. No que eu virei a mão, o cara ficou com cinco dedos na cara dele... E rodou, né. Até hoje nós não nos falamos, entendeu? Aí, eu falei 'agora vai lá em cima e fala'. 'Vai lá no pessoal [Depto. Pessoal] e fala."

Luís conta mais um episódio no qual o seu chefe teve que intervir. O chefe considerou que sua agressividade passou do limite. Ele responde ao chefe:

“(...) Eu sou viadinho sim, (...) Agora se esse pessoal baixo aqui é dessa forma, eu vou dar uma lição pra eles, como é que a pessoa tem que respeitar os outros e não é dessa forma'. (...) 'Eu vou chamar a polícia'. 'Se você chamar a polícia, vai servir pra você, você tá ameaçando'. Então, até hoje, eles se calaram, se fecharam. Mas é aquilo: eu trabalho, mas eles me deram desprezo, entendeu? (...) Agora só que tem o seguinte: eu, falar eu não vou, dentro da empresa, e também se falar, (...) aí vai ser uma coisa que vai complicar. 'Além de viado, tá com aids'. (...) Isso é que na minha cabeça tá, aquilo assim, entendeu? (...) E agora com uma notícia dessa, se cai na boca deles, e... (...). Então eu acho que em casa, eu vou, depois desse resultado com a assistente social, eu vou ver. (...) Se eu ficar ganhando o mesmo salário, eu prefiro mais ficar na minha 
casa e trabalhar de camelô."

Assim, Luís tem mais restrições do que Nei para revelar a notícia no trabalho. Observa-se que os dois passam por essa experiência reflexiva de forma muito diferente. Nei quer contar, apesar da ponderação a respeito do preconceito e da discriminação, ao passo que Luís opta por não contar. Já conheceu de perto as situações de agressividade que permeiam as relações quando está em cena o preconceito oriundo da diferença de escolha sexual. Ele já foi estigmatizado antes, sem ter o vírus. Nessa luta para se fazer respeitar também reage com violência física, porém não é a única forma de violência que sofre. Já vive a condição de isolamento no ambiente de trabalho. Portanto, não pretende contar para ninguém dali, que não seja amigo. Com a ajuda dos profissionais de saúde indicados, Luís pretende averiguar quais são seus direitos como portador do HIV para tomar decisões em relação ao seu trabalho.

\subsection{PSICANÁLISE DO PROCESSO DE ACONSELHAMENTO}

O termo psicanálise aqui se inscreve ligado à sua acepção enquanto teoria que empresta seus conceitos, sobretudo, os da teoria de D. W. WINNICOTT (já descritos) para esclarecimento dos processos em jogo no aconselhamento. Claro é, pois, que não se poderia falar propriamente em psicanálise, mas na aplicação da psicanálise a um determinado objeto. FREUD (1910; 1914) fez isso em Leonardo da Vinci, Moisés e, depois dele, tantos outros se arriscaram nessa atividade, hoje conhecida como psicanálise aplicada.

A psicanálise propriamente dita exerce-se no espaço da clínica atravessada pelos fenômenos transferenciais, enquanto que a psicanálise aplicada é um exercício teórico de aplicação de conceitos a uma determinada realidade, cujo dinamismo se distancia daquelas condições especialmente construídas.

A psicanálise tem na escuta sua ferramenta fundamental, tal como pretende ter o aconselhamento.

O desenvolvimento do presente estudo se encaminha para o seu objetivo principal, que é analisar as características das interações no processo de revelação do diagnóstico no contexto do aconselhamento sorológico segundo a versão de cada cliente entrevistado. 
Dito isso, reflete-se um pouco mais sobre as experiências desses sujeitos da pesquisa no que se refere ao lugar que eles se colocam no mundo e diante de outrem, e à maneira pela qual foram escutados em suas inquietações na situação específica de aconselhamento sorológico. Por meio das ilustrações de seus relatos, procura-se investigar melhor o espaço permitido (por aqueles serviços) para a entrada destes clientes em suas próprias vivências emocionais e no seu próprio psiquismo, diante da revelação do seu diagnóstico. Em outras palavras, investiga-se como a subjetividade se produz e é sustentada naqueles contextos intersubjetivos específicos.

Recupera-se aqui, a divisão grosseira entre os relatos dos sujeitos, e que foi utilizada na primeira categoria de análise (4.2.1). Entretanto, com o propósito de dinamizar a discussão, a seqüência de apresentação dos casos será diferente daquela. Assim, há os que consideraram o processo de aconselhamento satisfatório (Sílvio, Milton, Nei, Luís, Juvenal, Evandro Arnaldo, Mário, Pedro, Cássio, Bruno e Jonas) e há os que o consideraram pouco acolhedor às suas necessidades (Omar e Paulo). Começa-se pelos primeiros, como pode ser visto na esquematização abaixo. Os sujeitos foram agrupados em função da semelhança de seus relatos a respeito dos respectivos processos de aconselhamento.

Quadro 4. Agrupamento dos entrevistados, segundo a análise do processo de aconselhamento

\begin{tabular}{|c|}
\hline Psicanálise do processo de aconselhamento \\
\hline Sílvio e Milton \\
Nei, Luís e Juvenal \\
Evandro e Arnaldo \\
Mário e Pedro \\
Cássio \\
Bruno e Jonas \\
Omar e Paulo
\end{tabular}


4.3.1. Como se Processou o Aconselhamento de Sílvio e Milton; Nei, Luís e Juvenal; Evandro e Arnaldo; Mário e Pedro; Cássio; Bruno e Jonas

Os entrevistados contam em detalhes, à sua maneira, como foram recebidos pelas aconselhadoras para saber o resultado do seu teste e como transcorreram as conversas, o que cada um pôde falar:

\section{Sílvio}

“... eu fiz perguntas, né, mas eu fiz perguntas mais pras mulheres [suas parceiras] do que pra mim, que foi sobre trazer elas pra fazer o exame. Como que eu ia chegar nelas pra falar, como que eu ia chegar na minha família? Então, não foi tanto sobre o problema comigo, sobre a doença. As perguntas minhas foram mais pro lado delas, porque ela [a aconselhadora] chegou, perguntou, falou assim — 'você está mais preocupado com elas do que com você mesmo’ É, elas falaram isso pra mim — 'você está mais preocupado com elas'. Falei: — Estou! porque a gente sabendo duma coisa, a gente se preocupa com os outros também, né? Jamais agora se eu tenho uma coisa eu quero tá passando pra... [Sobre a transmissão do vírus] Não, eu não quero estar passando. Se eu cheguei e fiquei, é porque eu não sabia. Se a gente não sabe do que tá acontecendo, então a gente vai acabar prejudicando um monte de gente, né? Agora, eu jamais vou prejudicar os outros. Se eu me sinto prejudicado eu não vou querer o que é ruim pra mim, querer pros outros. Não! Então eu agora tô preocupado com elas, né. Quero o resultado delas, que seria das duas, né?"

Quando Silvio conta isso, cerca de quinze dias haviam se passado desde que lhe foi revelado seu diagnóstico. Havia, certamente, tido algum tempo para formular questões e dúvidas sobre si, sobre sua nova condição de saúde e sobre sua família. Como foi referido anteriormente, sentiu dificuldade num primeiro momento de formular questões: “de dez vai perguntar duas”, ele havia dito. Transcorrido algum tempo, parece ter havido a possibilidade de certa elaboração mental, de uma organização de idéias e pensamentos.

No momento em que transcorria a comunicação do resultado, parece não ter tido todo tempo e espaço para se colocar por meio de perguntas, como já foi dito anteriormente a seu respeito no ítem 4.2.1. As perguntas que conseguiu fazer “... mais para as mulheres..." do que para si, sugerem que, de pronto, o pensamento 
funcionou encadeando idéias e sentimentos ligados ao que é mais premente ou central na vida da pessoa. Daquela pessoa. Neste sentido, o caráter de singularidade deste encontro merece ser revestido de realce e respeito. Parece óbvio, mas tratandose de uma prática que segue um protocolo, com determinadas regras e etapas a serem cumpridas, pode-se perder isso de vista, inadvertidamente ou não. Na situação envolvendo Sílvio, parece ter havido sustentação de sua angústia e preocupação, e isso pode ser evidenciado no assinalamento feito pela aconselhadora, relatado acima. O manejo de suas preocupações (com as esposas) parece ter sido suficiente para permitir que outras questões aflorassem. Apesar das dificuldades e barreiras de vergonha, gênero e timidez, já apontadas, ele transitou no contexto de seu aconselhamento.

A vivência emocional de Sílvio é expressa por palavras que denotam também sentimentos de dúvida e desconhecimento ligados à provável experiência sexual infectante, culpabilidade por eventualmente ter transmitido o vírus às suas parceiras, que indicam o caminho à sua interlocutora de quais são os aspectos a serem abordados e acolhidos no encontro de revelação do diagnóstico.

Mas antes, já na coleta de sangue, no seu primeiro contato com o CTA, Sílvio sentiu-se cuidado e acolhido.

“As meninas aí trabalham bem, elas sabem como se dirigir às pessoas. (...) Eu não tenho nada que falar do tratamento delas, né. Elas até na hora, na hora de tirar o exame, que foge assim o sangue meu... Foge tudo, né, não tem veia. Ela falou: - 'não, então, vou por a agulha fininha aqui'. Aí tirou aqui. (...) Foi uma conversa normal. Elas sabem, elas têm jeito de chegar na pessoa pra transmitir a [pausa] a palavra, que é uma palavra difícil né, e se não tiver jeito, o resultado machuca a pessoa mesmo, né. Receber uma noticia de uma coisa que não tá esperando, né .(...) Então é, tem que ter jeito, tudo tem que ter jeito pra falar. Pra conversar. E se tiver jeito, é que nem um doente quando você sabe lidar com doente, ele vive mais porque ele tem que ter palavra de conforto, né. (...) É, é uma palavra de conforto. A palavra de conforto ajuda as pessoas, ela falou — 'você precisa ser forte pra lidar com isso, né. E a gente vai guiar, vai cuidar, o que você precisar tal, estamos a disposição. - E eu senti bem com isso, né. Às vezes a gente tem até que largar o pensamento da doença de lado, porque a gente tá vendo que tá sendo bem recebido. Então, elas são muito bacanas, as meninas, pra se dirigir essa conversa pra gente, elas estão 
bem preparadas pra isso. E a gente tem que pensar agora na gente, como lidar agora com isso, porque se a gente não tá acostumado (...) a lidar com o problema que tá, porque é resultado de emergência. (...) Resultado que pega de surpresa."

Deixar a doença de lado para usufruir daquele cuidado e daquele tempo de "negação temporária" é o que se pode chamar de "aguardar até ter condições para entrar em contato com a realidade, viver um pouco a experiência da ilusão", ou seja, ser provido, ser suprido adaptativamente.

\section{Milton}

Por meio de um mecanismo diferente, Milton obteve o mesmo ganho de tempo que Sílvio. Milton negou temporariamente aquela notícia pela confirmação de “já saber”. E, se ele já sabia, nada está lhe sendo dito de novo, pois aquilo (o HIV) já estava lá. Assim, quem se entristece - em sua projeção — é a aconselhadora. Ela ainda não sabia e por isso se abala e se surpreende com a naturalidade dele ao ouvir o resultado do seu teste.

"Eu não lembro agora quem me deu, o nome da moça, mas a gente conversou né. (...) E acho, ela ficou assim, né, eu percebi que ela ficou meio abalada. Eu, pessoalmente, já sabia que eu tinha. (...) Porque na juventude a gente apronta muito, eu estou com 29 anos, ainda sou jovem, mas quando a gente é adolescente e tudo, a gente apronta pra caramba, não pensa em conseqüência, né? Acha que nunca vai acontecer com a gente. Ela chegou em mim e conversou, foi muito simpática, me atendeu muito bem, tá? E falou: 'você tá com o vírus,' tudo. Eu recebi normalmente, perguntou se eu tinha alguma dúvida, a maioria das coisas eu já sabia, então não tinha muito que falar. Deixou um espaço aberto, pra eu poder, sei lá, me expressar. (...) Tanto que ela ficou admirada com a minha reação, até minha reação foi muito natural. (...) Primeiro ela conversou. (...) Antes de dar o resultado. Bem antes, nossa! Conversou bastante, perguntou o que eu sabia sobre o HIV, perguntou um monte de coisa. Eu respondi normalmente. Mas quando, assim, ela olhou a ficha, depois virou pra conversar, né? Mas eu já vi nos olhos dela que ela, ela sentiu aquele baque. (...) Ela olhou assim, e parece que, arregalou os olhos assim, meio espantada. Ela mudou o tom de voz, ficou bem assim, parecia tristinha. Daí como eu já estava desconfiando (...) eu tive a confirmação. Aí depois que ela conversou bastante, foi muito atenciosa, daí ela deu o resultado. Eu recebi normalmente, né? Daí, conversamos 
mais um tempo, né? Deu mais algumas explicações de como seria o tratamento. Se ele fosse necessário (...). Perguntou como é que eu estava. Se eu queria ficar mais um pouco, se eu queria, assim, conversar a respeito, tudo. Normalmente, normal. Tô bem, não adianta eu ficar lá 'é, morri’. Não adianta. Seria muito difícil, né, seria. Assim, pra mim. Não ia fazer isso nessa situação, então eu recebi de boa. Recebi normalmente. (...) Quando eu cheguei lá no aconselhador... Bom, vou contar como eu cheguei né. Justamente. Eu fiquei numa sala de espera, a aconselhadora chegou, chamou, para um lugar meio assim, uma salinha reservada, praticamente ninguém ficou sabendo. [A sala de aconselhamento fica nos fundos, em lugar reservado]. Sentou, começou a conversar, né. Entrevista padrão, né. Como eu te falei, ela ficou meio assim... Tanto que ela ficou assim, como eu posso explicar? Ficou meio 'passada'. (...) Ficou bem mais abalada que eu. Porque assim, a minha reação foi normal, como se eu não tivesse nada. E ela ficou assim, ela ficou meio tristinha, tudo. Eu percebi isso. Quer dizer, eu fiquei com dó, com pena dela. (...) Como eu disse, é uma atenção muito grande! É uma atenção que eles te dão que você não se sente rejeitado. Não se sente por baixo. Tanto que no dia que teve a reunião, uma das aconselhadoras chegou em mim e conversou. A segunda foi uma outra aconselhadora. (...) Não lembro o nome dela. Nossa, ela me tratou super bem, com carinho... Ela foi muito [frisa a palavra] legal."

O que Milton relatou parece significar que, quando o setting é constituído de modo a sustentar a angústia do sujeito em aconselhamento, torna-se possível agir com naturalidade e, mais do que isso, pode-se usar os próprios mecanismos (de negação, de projeção). Esses mecanismos foram utilizados por ele para se defender do horror que a situação provocou, mesmo que considere ser esta a conseqüência do que ele já fez na vida. Para que o setting seja constituído de forma suportiva, é preciso que algumas funções do ambiente permitam a colocação em marcha dos recursos do psiquismo. O sujeito os possui, mas ele precisa ter a chance para utilizálos na elaboração de sentimentos e na resolução dos conflitos que se apresentam naquele momento. Isso se efetiva pela presença da aconselhadora, que, no caso de Milton, permitiu que este “a usasse". Essa é uma expressão winnicottiana que significa: fornecer suprimento adaptativo de provisões para que ele tenha tempo de se recuperar e possa usar as suas próprias. Até mesmo a entrevista padrão (coleta de dados epidemiológico), que, para alguns entrevistados, foi insuportável de aturar, 
para Milton foi um prelúdio. De acordo com a psicanálise winnicottiana, pode-se sugerir, como explicação, que o manejo possibilitou e criou o holding. O holding proporcionou a Milton entrar em contato, aos poucos, com o real da notícia. Os mecanismos funcionaram por algum tempo - somente o necessário. Se usados excessivamente, estes mecanismos poderiam criar a falsidade, uma espécie de máscara para evitar o sofrimento pelo resultado tão temido (mas já sabido). Eles foram deixando de agir quando Milton já podia tolerar a realidade com a ajuda da aconselhadora, do que ela representou para ele.

Passando às considerações de outro entrevistado:

\section{Luís}

"Bom, a médica que me deu esse resultado é a doutora... [tenta lembrar o nome] Foi uma ótima pessoa, entendeu, ela relaxou primeiro. Eu já senti, a gente já sente a diferença, né, porque ela começou a perguntar 'ah, eu vou te fazer algumas perguntas e você me responde'. Então, como eu tenho amigos que já passaram por esse processo, eu já tinha noção da coisa como que era. Aí eu falei: 'tudo bem'. (...) e ela chegou 'olha, você desconfiava de alguma coisa? Eu falei 'sinceramente, eu já desconfiava. Desde o ano passado que eu vinha sentindo uns probleminhas... e tudo indica que esse resultado, seja o que for, eu estou apto a receber.' Ela foi e explicou: 'agora, a partir de hoje...', me explicou tudo que eu não devia fazer, entendeu, pelo menos na relação [sexual], tudo, de uma intimidade, se eu conhecia essa pessoa, eu falei 'essa pessoa [a fonte da infecção], pra ser bem sincero, eu não lembro... quem foi porque não sei se foi novo ou velho, não tenho conhecimento dessa pessoa'. E eu adorei muito (...) No meu caso, eu acho que pra mim, são uns excelente profissional. (...) $\mathrm{Eu}$ achei, assim, que, dessa forma que eles... aqui chega e transmite pra gente... Tanto senso de humor, de carinho que eles têm é..., pra mim foi ótimo. Eu não acho, assim, que se tiver que mudar, só se eles vão se reunir e deparar com alguma coisa porque eu achei ótimo.

Indagado se teria algo a acrescentar ao trabalho de aconselhamento responde:

"Nada a acrescentar e nem diminuir... (...) ela falou assim 'e se der positivo ou negativo, qual a sua reação?'. 'Não, a reação vai ser a mesma, eu vou fazer o quê? Eu não vou me matar. Eu quero viver, é uma coisa que eu vou lutar pra eu viver, entendeu?'. Aí ela, até nós brincamos um pouquinho pra ela dar o resultado, né. Ela foi super maravilhosa, é uma profissional e eu tiro o meu chapéu pra ela, entendeu? Foi 'dez' assim...” 
Como já foi apresentado antes, Luís estava habituado a sofrer experiências violentas em decorrência de sua escolha sexual homossexual. Esse trecho de sua entrevista mostra como ele pode ser dócil e receber amigavelmente uma revelação de algo ruim e preocupante. $\mathrm{O}$ ambiente facilitador, representado pela aconselhadora the propiciou a experiência de mutualidade. Luís pôde mostrar seu lado menos agressivo, menos violento, mesmo suportando aquela revelação. Com essa forma de funcionamento dá indícios de que ruma em direção à saúde.

\section{Juvenal}

"Pra mim... A pessoa que me atendeu ela procurou o máximo, né... Como ela me contar, como me dar o resultado, ficou à disposição pra eu voltar aqui pra conversar se eu tivesse alguma dúvida, entendeu? Não sei, pra mim foi um atendimento... Bom. Não tenho o que falar quanto ao atendimento..."

Juvenal havia recebido um resultado negativo anteriormente e diz como percebeu a diferença:

"Você sente... Mas não assim de rejeição... Mas é a maneira como a pessoa fica pra te dar o resultado, porque é bem difícil. Tanto pra você que vai dar o resultado e principalmente pra você que vai receber. Então, a pessoa tem que ter muito tato, muito, né... porque realmente tem diferença porque uma pessoa é super legal, pediu para ter forças... né, assim..."

Ele percebe diferença na pessoa e é capaz de transitar neste espaço criado, exatamente pela posição ocupada pelo aconselhador de não obstaculizar a circulação do aconselhado em torno e diante de sua figura. Há um compartilhamento do mesmo espaço naquele tempo transcorrido. Ele percebe a dificuldade do processo, mas o ambiente apresentado é bom. Juvenal tem dificuldade para apontar falhas, o negativo e a desconfiança que também estão presentes no processo, e que são justificadas no dizer de Juvenal.

“Então... A impressão, assim, que ela pra mim foi meio perdida, (...) [Em] Como falar... Como chegar diretamente em mim pra falar o que falou, mas isso é compreensível porque é difícil. (...) É muito difícil, não só pra quem recebe como também para quem vai transmitir. (...) Acho que foi isso, pra mim eu estou satisfeito, o atendimento é bom, as pessoas também... Não te tratam com indiferença... (...) E eu tenho que ir 
levando. Fazer o que? Uma coisa que eu falei pra ela na orientação o que eu fiz, não uma vez, duas, e, aconteceu. E agora eu tenho que... aceitar. (...) Ela fez primeiro as perguntas da primeira vez... Sabe por que eu me desconfiei? Porque ela falou que ia chamar a outra pessoa pra estar acompanhando ela, pra ver como ela estava desenvolvendo no trabalho. (...) Primeiro foi aquele processo... De questionário: se você usava preservativo, se usava drogas... Tanto é que fica aquele mistério... Aí, no final... Dá a notícia.”

A pesquisadora pergunta: - podia ser invertido, podia ser diferente? Responde:

“Pra falar a verdade, sim, Porque dá uma angústia! (...) Já dá logo [o resultado] e depois vai perguntar, porque toda aquela angústia ali, aquele desespero... Só vendo... Nossa! Eu gelava! Eu tava gelado, entendeu? Nossa! Eu nunca gelei tanto assim... (...) E não é culpa da pessoa, né? Ela está tentando fazer o melhor... É um trem complicado, né? (...) Algumas pessoas (...) aparecem por aqui que se desesperam, né? Que talvez a pessoa [a aconselhadora] espera até pra se proteger também, né? Para se resguardar um pouco. E pode ter também, uma ou outra pessoa que... Sei lá, que é agressivo, sei lá, que se altera, que fala ríspido com você, que não tem nada a ver e que só está querendo ajudar. Porque está aqui só para ajudar. Então, da minha parte eu penso assim... Mas... Era mais fácil.” [Dar o resultado antes de fazer as perguntas].

Juvenal consegue apontar o que faltou no aconselhamento: espaço para explorar sua negatividade. Ele não quis contaminar um ambiente tão bom, apontando o que não gostou: preferia ter recebido logo o resultado. Ele remete ao tempo para o preenchimento do questionário como sendo necessário ao preparo do aconselhador contra possíveis hostilidades dos clientes. Não era o caso dele, mas ele reconhece que não é fácil para a aconselhadora perceber a sutileza de suas necessidades. Sua fala permite a análise dos limites do instrumento. Há coisas que não poderão ser resolvidas ali. Por vezes nem serão identificadas como foi com Juvenal. Este entrevistado apontou para a agressividade de algumas pessoas que podem eclodir em situações ríspidas em relação às aconselhadoras. Isso confirma as múltiplas situações que podem ser vividas no aconselhamento.

\section{Evandro e Arnaldo}

Às vezes o aconselhador se depara com alguém resistente em relação ao 
senso de realidade como é o caso de Evandro e Arnaldo, os próximos a contarem como foram os seus aconselhamentos. Não se pode teimar com eles, dentro da concepção de aconselhamento que o presente estudo enfoca. É desaconselhável confrontá-los em suas verdades, pois elas devem ser respeitadas de pronto para que no tempo deles a realidade possa se instalar, caso isso seja possível.

\section{Evandro}

"Primeiro a pessoa que me recebeu lá, ela me fez várias perguntas, aí depois que ela me deu o resultado. Falou que era soro reagente, né? Que é o mesmo que positivo. (...) Bom, eu já fui preparado para receber o sim ou o não, porque em 1995 eu fui doar sangue lá na Santa Casa e a "menina" [pessoa que o atendeu] falou para eu ir ao Hospital das Clínicas. Aí eu fiquei com a suspeita e mesmo assim eu não fui. Por isso eu resolvi participar desta palestra que era para eu ver se eu tinha alguma coisa. (...) Agora que eu resolvi ir [saber]. (...) Eu estava com uma dúvida. Ainda mais porque eu comecei a namorar uma menina, né, e eu falei: 'não posso casar com ela sem fazer. Eu tenho que ir lá saber o que pode estar acontecendo'. (...) Perguntou meu nome... Tipo assim, já vai te preparando para o resultado que você vai receber. Eu não sei se é verdade, mas me parece que as pessoas que vão lá para a salinha são as pessoas que recebem positivo? Ou é impressão minha? (...) Eu, no meu caso, preferia que ela tivesse dado o resultado primeiro e depois fizesse as perguntas. Porque eu já fui preparado, já fui fortalecido. Mas têm aquelas pessoas que não vão. (...) [A aconselhadora] falou que eu poderia me tratar, que eu poderia usar preservativo, que eu poderia cuidar melhor da minha vida, de agora em diante."

Evandro considerou boa a conversa com a aconselhadora e esta foi atenciosa com ele. Na comunicação do segundo resultado com outra aconselhadora:

"Ela também foi uma pessoa muito legal. Aí eu já fui mais preparado ainda do que a primeira vez. (...) Ela falou as mesmas coisas (...) e ela me indicou depois da entrevista que eu poderia estar passando com uma psicóloga, que eu poderia estar me tratando, que eu poderia estar cuidando melhor da minha vida."

Esse entrevistado teve no aconselhamento a possibilidade de "tocar de leve" na sua realidade de ser um portador do HIV. Esse contato é de suma importância no seu caso. A principal razão disso é que está vivendo um processo de supressão e corte com a realidade, negando desde 1995 que é soropositivo. Mais recentemente, 
começou a negar também sua orientação sexual homossexual. Por fim, acredita que Deus vai curá-lo. O ambiente facilitador, proporcionado em seus dois aconselhamentos, manteve-o preso a algum aspecto da realidade que o fez não só aceitar o resultado como, também, agendar consulta com o infectologista do SAE e participar das duas entrevistas oferecidas para ele "contar como foi comunicado o resultado do seu teste". Esses dois movimentos demandaram dele o enfrentamento da realidade, pois nas duas situações ele teve que providenciar os encontros. Ele foi pessoalmente até o serviço de assistência se inscrever e telefonou, ele próprio, para a pesquisadora para marcar a entrevistas.

A forma como se constituiu o seu primeiro aconselhamento permitiu-lhe entrar em contato com aspectos primitivos de seu desenvolvimento de uma forma não intrusiva. Pois não se esquivou nem se sentiu atacado como da primeira vez que fez uma sorologia. Pode-se levantar a hipótese de ter sido esse o enlaçamento que o direcionou ao prosseguimento da própria vida. Algo da ordem de um manejo da situação (foi-lhe oferecido café e água) que o sustenta pelo tempo que ele necessitar (a aconselhadora aguardou que ele chorasse, ele se acalmou e foi confortado).

\section{Arnaldo}

"Esse resultado foi assim: eu tava muito apreensivo porque até então um amigo meu tinha o vírus e já estava internado. Eu sabia que ele tinha e então eu corri pra poder fazer o exame também. Não que eu tivesse alguma coisa com ele, é porque eu tinha contato, de cuidar dele: cortar o cabelo, fazer pé de cabelo, usar navalha, alicate de unha, tudo. E naquelas coisas que eu fazia, eu acabei cortando ele e cortando eu ao mesmo tempo... Então me deu aquele medo; então eu procurei o CTA através dele mesmo e... fiz o exame. O dia que eu vim buscar - nossa, esse dia é o dia que você pensa que você vai sair dali com um sim, você vai comemorar. Não, você sai dali sabendo que você não tem nada, você vai comemorar e, saber que você tem alguma coisa dá vontade de suicídio. (...) Porém, quando eu cheguei aqui, as moças que me atenderam - a [nome da aconselhadora] e mais uma outra - elas me deram, uma estrutura assim, um apoio tão grande que eu saí daqui assim como se fosse a coisa mais normal do mundo. Embora que a cabeça da gente, por mais que você pense que é normal, destrói muitos sonhos, quebra muitos planos, entendeu? Eu tinha planos de crescer, assim, como pessoa, mas também financeiramente... Talvez isso possa acontecer, porque eu não 
posso mais planejar meu futuro, porque eu não sei quanto tempo de vida a gente vai ter mesmo... (...) Então eu tive, eu não tive que aceitar; eu aprendi a aceitar aqui... Porque lá fora eu só falava: 'Deus me livre; nunca isso comigo, nunca', mas aqui eu aprendi como lidar com isso; aprendi como aceitar [frisa a palavra] isso, entendeu? (...) Então naquele dia eu saí daqui e fiquei assim... Realmente, no primeiro momento eu me perdi; eu me perdi, me perdi mesmo; eu me perdi aqui em [nomeia o bairro]. Eu perdi o rumo de minha vida. Eu saí daqui eram 11:30 da manhã, era 11:30 da manhã e eu tinha que tomar um ônibus, e ir para o [nomeia o ônibus], eu tomei um carro que fui parar na Zona Leste... Eu fiquei desnorteado; cheguei em casa era meia-noite e não consegui dormir pensando naquilo. (...) O segundo resultado que eu vim buscar hoje eu já me adaptei um pouco mais à idéia. Então agora eu também conversei com a [fala o nome da segunda aconselhadora] que me atendeu; ela também me deu uma estrutura, um preparo muito bom pra isso: que eu tenho que me cuidar, que não sei o quê, que isso não é uma coisa do outro mundo, né, aquela coisa. Então a gente vai aprendendo a lidar com isso. Agora que veio outra coisa na minha cabeça: quando eu nasci, a tuberculose não tinha cura, hoje em dia tem. Então quem sabe daqui uns dez, quinze anos tenha cura pra AIDS também e eu possa ser um desses privilegiados porque até então você deve de estar controlando aquilo ali. $\mathrm{O}$ vírus te transforma no doente; então você vai maneirando ele e quem sabe um dia você se livra..."

Após o tempo em que se perdeu, Arnaldo começa a percorrer um outro caminho. Ele recupera em sua história de vida aquelas lembranças ligadas a processos saúde-doença já conhecidos seus. Isso permite que ele transite por uma área onde nem está desgovernado, nem está paralisado. Está numa área intermediária, onde a ocorrência de fenômenos transicionais torna-se possível: a possibilidade de cura da aids no futuro, as formas de luta contra a doença, o cuidado, etc. A ilusão parece ser a responsável pela criação deste processo. Em seguida, fala de uma preparação para o resultado, feita pela aconselhadora e facilitadora desta experiência:

“Quando ela perguntou 'caso acontecesse, se acontecesse' se eu sabia que era uma coisa normal, não sei o que... e me contou estórias e começou assim... Bem, ela, eu vou dizer, como psicóloga, ela é uma maravilha de pessoa, ela consegue dominar o medo de qualquer um [ri]. Eu entrei pensando naquilo; eu pensava 'quando eu sair daqui, que ia me 
jogar debaixo de um carro'. Então eu errei e fui andar de metrô. Mas não, foi o contrário, porque chegou a hora que ela falou assim: 'você sabe que você é soropositivo, não sei o que, né'. Eu falei: 'pois é'. Sem sentir eu falei: 'pois é'. Então foi de uma forma assim, parece que tão... Não sei, tão comum que eu recebi aquilo assim... Ela me falou muito, me explicou como pegava a doença e que não sei o que, que a vida continuava, uma vida normal, porém com regras. E o que eu tenho a dizer dela é que ela foi uma pessoa muito sábia nessa hora porque não é qualquer cabeça que... A minha cabeça mesmo se não souber lidar muito bem eu fico muito doido."

Arnaldo já tinha a sensação de ser soropositivo:

"Eu já tinha essa sensação porque das outras vezes eu não tive isso, eu não sentia isso. Então, quando eu soube que este cara tava e que eu havia entrado em contato com o sangue dele e com o meu ao mesmo tempo, então já começou aquela coisa, aquela agonia, entendeu?"

$\mathrm{O}$ aconselhador respeitou e permitiu que as crenças de Evandro e Arnaldo fossem preservadas. As do primeiro, com relação ao fato de que Deus iria curá-lo e as do segundo, de que a via de infecção foi a pérfuro-cortante. A dificuldade de entrar em contato com a realidade, de cada um deles, estava operando. Esta operação prevaleceria pelo tempo que eles necessitassem. Quando Arnaldo diz que a aconselhadora lhe deu estrutura, tirou-lhe o medo, era disso que ele estava falando: da espera e da sabedoria dela em lidar com o assunto, para que ele pudesse permanecer no ponto em que estava de seu percurso na realidade da notícia.

A ilusão (de onipotência, de invulnerabilidade e de plenitude de provisões) pode ser suficiente por algum tempo, mas não por todo o tempo. $\mathrm{O}$ contato com o real é inevitável e necessário para que se ative os recursos verdadeiros, essenciais à luta pela sobrevivência ao HIV.

Como disse Arnaldo, ele veio fazer o teste quando soube que seu amigo era soropositivo. Estava implicado em seu exame e, apesar de ter esperança de que fosse negativo, havia algo lhe indicando a positividade, e isto era a própria rememoração das situações de risco vividas até então. De alguma forma, a manifestação desse "toque" de realidade podia representar o início de um caminho viável a percorrer em direção à adaptação ao seu processo saúde-doença. 


\section{Pedro e Mário}

Pedro e Mário, em contrapartida, tinham não só a suspeita, mas certo apelo da soropositividade em função de seus relacionamentos amorosos, de seus parceiros sabidamente infectados pelo HIV. O resultado do primeiro teste foi quase uma confirmação, e o aconselhador precisou abrir lugar para a fala ligada mais aos relacionamentos, do que para o exame propriamente dito, como eles contam.

\section{Pedro}

"Eu não sabia se fazia o teste; aí eu fiz, colhi a primeira vez, aí no caso, o resultado eles não entregam à gente e a gente vai embora. Eles sentam, conversam um pouco. Mas como eu já tinha, tipo, um pouco de dúvida porque meu parceiro já estava com a doença, ele faleceu, então assim, eu não vim pensando que não poderia estar, né. Aí foi ótimo; ela falou comigo super bem, me explicou que têm pessoas que vem e faz besteira, né? E me deu uns conselhos muito bons, né? Aí eu fiz o segundo teste, né, aí deu [positivo], não tinha como não dar, né? Aí foi assim... Não foi ruim, porque a dor que eu estou passando agora [pela perda do parceiro]... Isso [o resultado positivo] pra mim não está sendo nada, entendeu? Porque o que a gente quer é a pessoa com a gente, né? Então este resultado não é que foi... Foi ruim? Foi... Mas, o que a gente pode fazer, né? Tem que aceitar e viver, né?"

Da segunda vez, a vez da confirmação do exame positivo:

"Ela [outra aconselhadora] falou: 'tudo bem?' Eu falei: 'tudo bem'. Aí ela perguntou o que eu achava. 'Olha, eu acredito que eu não vim pensando que eu não esteja [HIV positivo] porque não tem condições, né'. Confio em Deus, né, mas assim, acho que com certeza, porque não tinha como não estar, né. Eu transava com ele sem camisinha, sempre, por sete anos, há quase sete anos... então, assim, eu não posso ter intenção que não. (...) mas esse é um problema que eu vou ter que resolver, né. E eu não posso ficar culpando ele, julgando ele por isso, aquilo. Não, eu convivi com ele, poderia ser com outra pessoa; eu poderia ter passado pra ele ou ele[para mim], entendeu? Mas agora o que eu posso fazer? Nada. Eu tenho que cuidar da minha vida. (...) O resultado da primeira vez foi, foi ruim. Foi ruim, foi, mas não na segunda vez, não. Na segunda vez você já começa a vir a primeira vez; que você é positivo... Eu já vim mais conformado, né... Conformado e... Aceitando, né. Como ela falou: 'você tem que viver sua vida, né, mesmo tendo uma 
doença, que tem tratamento, uma medicação que precisar.' Aí eu falei: 'não, com certeza'."

Durante a comunicação do seu resultado HIV positivo, Pedro pôde falar de sua angústia pela perda do parceiro. O setting estabelecido possibilitou isso. Seus conteúdos estavam relacionados ao seu momento de vida, mais do que ao resultado em si. Foi aguardado o tempo necessário para tratar da sua existência no mundo, e não exclusivamente do HIV. Antes sustentado pelo parceiro, agora teria que se constituir de outro jeito, trabalhando ou indo viver com a irmã. A aconselhadora lançou mão de recursos da rede social e institucional voltada aos cuidados às pessoas que vivem com HIV. Ela o encaminhou a uma ONG que oferece apoio jurídico para o requerimento de pensões às pessoas que convivem sem união civil. Dessa maneira a aconselhadora sustentava as demandas de Pedro, ao lhe recomendar um dispositivo que pudesse provê-lo em sua necessidade específica.

"Ah, eu falei... Eu falei a minha história, né? Eu não sei, assim, ela falou que eu só estava falando dele... Assim, geralmente a minha preocupação maior é estar trabalhando... (...) Mesmo porque ele [parceiro] deu três meses [de aluguel], então eu vou ter que ficar esses três meses. (...) Até lá, se eu conseguir serviço, eu realmente vou ter que morar com a minha irmã porque não dá... eu fico perdido, sabe? (...) É porque assim; estava tão recente o... Quando descobriu tudo e faleceu que... Ela me passou, quer dizer, ela me passou o resultado e pra mim... Eu senti um pouco um choque lá, só que não foi tão forte quanto à perda. (...) estou tentando me controlar, né?"

Percebe-se nesse relato, que o tempo demandado por Pedro para saber de seu resultado é um pouco maior do que o tempo do seu aconselhamento. Além disso, a ajuda de que ele necessita excede também os limites deste dispositivo (o aconselhamento). Sua condição psicológica requer um tipo de ajuda adicional, que não se encontra disponível nos CTA. Seu processo de luto (referido anteriormente) ainda não terminou. Essa ajuda pode vir a acontecer, ou não, dependendo da existência de profissionais de saúde mental no serviço aonde ele irá. É um fio de esperança para que ele possa sair recuperado da dupla situação traumática (perda do companheiro e soropositividade) para caminhar rumo à sua autonomia. Mas é um outro passo a dar, é o passo seguinte. 


\section{Mário}

Apesar de sua soropositividade estar associada à de seu companheiro (como Pedro), Mário conta com a presença viva dele, inclusive para acompanhá-lo ao CTA, como já foi mencionado. Mas, mesmo sabendo dessa soropositividade presente em suas relações sexuais, essas foram desprotegidas. Mas Mário não esperava se infectar. Por essa razão, seu processo de aconselhamento sorológico se inicia pela própria surpresa, embora essa não o impeça de entrar imediatamente em contato com seu sofrimento.

"Tive uma sensação que nunca tinha sentido antes. (...) Eu fiquei refletindo sobre as coisas que ela estava falando. Ela me falou coisas boas, assim. Que talvez não tinha pensado muito. Nunca tinha ouvido assim, de ninguém. Coisas boas, assim, que eu fiquei refletindo, fiquei pensando. Na mesma hora fui amenizando aquilo... Que eu podia estar sozinho... [sem o parceiro] Que eu sabia que depois eu podia falar com meu parceiro... Ele é muito bom. E eu não via a hora de chegar em casa para conversar com ele logo. Agora, com ela foi bom. Ela amenizou bastante assim. (...) [Durante a conversa] Eu fiquei sem palavras. Durante um bom tempo, até. Eu queria que ela falasse alguma coisa para retardar aquilo que eu tava sentindo, assim, e ela não falava... Ela estava dando um tempo para mim. Para refletir. (...) Eu abaixei a cabeça, assim [mostra com a cabeça], respirei fundo, falei: 'bola pra frente!' Vamos fazer outro resultado! [referindo-se ao exame confirmatório] (...) Eu estou com uma pessoa que está com essa doença. Sei lá, eu senti mesmo porque... Então eu percebi que me descuidei um pouco. Então fui me preparando para isso. Mas sabia que podia dar errado, que podia dar negativo, mas... Estava me preparando. Tanto que eu até falei para ela [para a aconselhadora]. Aliás, uma cartomante, até, que me falou que devia ter muuuito cuidado com a saúde que podia acontecer alguma coisa. Eu fiquei com mais medo ainda. Vim fazer com mais... Quando chegou o dia, eu cheguei aqui, marquei o horário certinho, tudo. Já desconfiei, que quando eu liguei aqui, a pessoa perguntou se era Mário, perguntou o nome do meio' ... Falou que estava pronto. Depois falou: 'espera, espera aí um pouquinho'. Daí eu fiquei esperando. Ela falou: 'Mário?' Eu falei: 'é'. E ela: 'ah, não está pronto não, Mário.' E estava pronto. Cheguei aqui, sentei aqui na mesa. A aconselhadora não achava o resultado, não achava o exame. Perguntou para mim se eu tinha certeza se era o dia que tinha marcado, eu falei que tinha. Aí ela teve que ligar lá para o 
laboratório e pedir um fax. A hora que ela me viu, eu não sabia o que fazer: eu ficava suando frio, tive que esperar um pouquinho, enquanto ela atendia um outro rapaz... Aí ela me chamou, falou para mim: 'é aquilo mesmo: 'demorou, mas o resultado não é bom não'. Aí eu falei para ela que eu já tinha desconfiado... (...) A gente sai daqui parece que está sozinho no mundo, solitário. E conversando [com a aconselhadora] parece que não tem nada. Vou para casa, com o tempo é que a coisa vai... Por que? Por que? Mas eu vou para casa e fico de cabelo em pé. Mas... é um baque muito forte. Elas [as aconselhadoras] fazem o que podem. Elas falam, você sente que as palavras são certas, na hora certa. $\mathrm{O}$ duro é quando você sai daqui. $\mathrm{Na}$ verdade você quer levar elas para casa com você. Para ir conversando com você até lá. Ir te amenizando, confortando..."

Mário fala do desencontro das informações, esboçando sua percepção de certa desorganização de arquivos na instituição, que desencadeou nele desconforto, desconfiança e ansiedade. Mário trazia dentro de si uma crença que o fez vencer o medo e insistir na consulta para aquele dia. De certa forma, ele fez um teste de realidade ali. Sabia que seu parceiro era soropositivo, teve relações sem preservativo com ele, foi realizar um teste sorológico anti-HIV. Por isso sofreu, por saber antecipadamente que podia perder sua integridade imunológica. No entanto, não queria estar tão perto dessa verdade. O tempo necessário de afastamento deste saber foi dado pela forma como a aconselhadora o acolheu. Esta deu-lhe os instantes necessários para "tomar fôlego", para que pudesse usar o espaço, para refletir e para começar a assimilar o resultado. Mesmo querendo que ela falasse. Foi suficientemente bom o ambiente que foi criado, pois ele pôde usá-lo sem ser invadido. A função de holding parece ter sido desempenhada pela aconselhadora.

\section{Cássio}

Como Cássio tinha a expectativa do segundo exame (confirmatório), os dados obtidos foram parciais, pois a insistência no assunto poderia forçar sua produção distorcida.

"Você quer saber como foi a notícia? (...) É preocupante, né, porque há alguns anos atrás eu fiz e deu negativo, há muito tempo atrás eu venho fazendo, (...) Que mais que você quer saber?

A pesquisadora responde com outra pergunta: - como foi a conversa?

"Ela me chamou, fez perguntas sobre parceiros, sobre preservativo. Eu 
usava de vez em quando com uma pessoa, mas às vezes eu tinha me prevenido dessas coisas. [Conta sobre seu parceiro]. Depois, conheci uma outra pessoa e ele mostrou também o exame dele, constando a informação que ele era sadio, não tinha nada de doença, né, e eu como estou só com ele direitinho nessa parte [como parceiro], eu resolvi fazer isso daí também, para saber, para ficar assim, mais seguro né? A senhora me deixou só contando as coisas até agora... (...) $\mathrm{Na}$ minha opinião, eu acho que vai depender muito do estado de espírito de cada um, de cada pessoa, né. Tem pessoas que realmente não aceitam este resultado, né? Inclusive esta pessoa. Ela já é desta área mesmo. Gay, né? Gay. Porque têm pessoas que aceitam, né? Mas aceitam com todo o cuidado. Eu também, eu estou... Se realmente der positivo... Porque ela pediu para fazer de novo, então a gente vai fazer. E se por acaso for, a gente tem que conviver, tem que aceitar. Conviver, né, de maneira agradável e boa. E não ficar num estado assim: 'ah eu estou com isso, eu não vou viver muito tempo, não sei o que.' Tem um amigo meu que ficou com isso daí e quando eu encontrei com ele, ele nem anda, ficou numa depressão terrível... Agora eu, se realmente for positivo mesmo, eu tenho que conviver com ela direitinho e fazer tudo para poder viver."

Como foi observado, Cássio tem dificuldade para abordar o momento da comunicação do seu resultado, talvez pela expectativa de um resultado negativo na segunda amostra de sangue. Ele tem dificuldade também para se considerar em risco, seja por não se assumir como sendo homossexual (não é gay), seja por ter relações sexuais esporádicas com um único parceiro que é "sadio". Cássio sinaliza que há necessidade de cuidado na hora da revelação do diagnóstico para que o cliente o aceite mais facilmente e busque o tratamento. Pelo que relatou, ele parece ter obtido isso em seu primeiro aconselhamento. Sobre o segundo aconselhamento não se tem informações, uma vez que Cássio se submeteu a ele antes do horário marcado, cancelando a segunda entrevista da pesquisa.

\section{Bruno}

Ao contrário de Cássio, Bruno está imerso no momento de sua comunicação do resultado, que conta em detalhes:

"Mas foi assim: ela foi ótima comigo na hora que ela me contou, sabe? Ela teve paciência. Porque ela viu que eu fiquei sem cor. E eu falava: 'Ai não acredito, não pode! Você tem certeza?' Ela foi muito calma. Foi 
bom. E foi só! (...) Aí quando ela falou: 'não, então sua amostra foi positiva, você está infectado.' Eu: 'quê?' Aí eu já perdi a cor, assim. Foi isso, né? Mas estou tentando agir normalmente como se nada tivesse acontecido. (...) Aí a gente entrou na sala, eu sentei. Não teve muito diálogo porque ela entrou já com o resultado: 'Ah, então, você vai ter que ser forte, mas essa amostra foi positiva.' (...) Não teve muito diálogo entre eu e ela na hora porque eu não quis conversar mais, entendeu? (...) ... eu pedi pra ela: 'Não, fala logo.' Porque eu não gosto, sabe assim... Eu prefiro ouvir na lata o que é bom ou ruim, porque eu acho que vou absorver mais fácil isso, entendeu? Quando é dado o resultado na cara, mesmo negativo ou positivo eu prefiro que seja bem direta. (...) Eu não dei muita oportunidade pra ela na hora que ela me contou. (...) pra ela conversar comigo. Porque na hora eu não me senti bem, né? (...) Olhava pra minha mão e só falava pra ela assim: 'ai, olha, eu tô branco!' (...) 'Ai, como você fala isso na minha cara?' Mas aí depois eu comecei a pensar. Aí ela me deu um número de telefone. 'Olha você me liga na terça-feira, pra gente saber se o outro resultado veio [o detuned].' (...) Aí eu falei, 'tá bom, te ligo sim.' (...) Mas saí rindo de dentro da sala, porque eu tinha amigos me esperando lá fora. Não queria mostrar pra eles naquele momento. (...) E hoje, eu senti... 'Preciso conversar com a [nome da aconselhadora].' Aí hoje que eu fui dar espaço pra conversar com ela, entendeu? Pra eu também desabafar pra ela o que eu estava sentindo, que não deu tempo de fazer naquele dia. Pra ela poder me falar também, me explicar algumas coisas, né?”

Bruno fala sobre a forma como a comunicação do resultado transcorreu. Ele faz considerações acerca do papel da aconselhadora e de como o cliente pode lidar melhor com o resultado, Bruno conta:

"É tudo questão de esperar a psicóloga, a aconselhadora terminar de falar e de explicar. Porque não para aqui, entendeu? Então é importante sim a maneira que você pega o resultado. É isso que vai te motivar ou a querer se tratar, a querer cuidar de você mesmo ou então simplesmente, meu amor, a sumir do mundo, esquecer de tudo, fingir que isso nunca aconteceu. Porque tem muita gente que faz isso. Pega: 'ah tá, é positivo? Tá!' Nunca mais volta, não quer saber de nada, não quer se tratar. Ai passa o tempo, muitos se matam por isso e hoje em dia pelos medicamentos que tem, tudo que tem, acho que ninguém morre de aids, entendeu? (...) Dá para viver muitos e muitos anos. (...) eu acho que você vive assim, talvez eternamente. (...) Eu digo as coisas que você faz, não vai mudar em nada. Você só vai tomar mais cuidado, se precaver mais de 
algumas coisas. Mas você vai ter uma vida normal como qualquer outra pessoa."

Volta a falar do momento da comunicação do resultado:

"Acho que você não pode enrolar mesmo pra falar, sabe? Vem com conversinha, explicar... Isso, não! Eu acho que você tem que chegar, eu acho que você digere ele mais fácil quando ele é falado na cara mesmo. (...) Desconversar até chegar ali? Não! A pessoa fica mais nervosa. Então chega: pá! Dá o resultado! Entendeu? (...) Que foi assim que aconteceu comigo. Eu digeri aquilo com muita facilidade, mesmo. Porque ai, na hora eu perdi a noção e tudo. Mas pelo menos, ai, ela não me enganou em momento algum, não tentou me enrolar, não pediu pra vir parente. (...) E eu acho que a conversa tem que ser bem direta mesmo, com jeitinho, entendeu? Igual elas todas aqui têm esse jeitinho. Já passei por várias aqui. Elas têm jeitinho sim, pra falar. Elas estão sendo ótimas, eu acho. Pelo menos comigo foram excelentes. (...) A ficha que eu preenchi foi antes. Acho que foi no outro exame. Não foi na entrega do positivo. (...) Ou fez? Num lembro. Acho que fez... Eu tava tão lesada na hora, que eu não lembro de nada, menina. (...) Passa sua vida inteira na sua frente, assim, em frações de segundos. Passa tudo. Você se vê criança, se vê adulto de novo. Entendeu? Tudo, tudo, tudo o que você vive passa, na hora, na sua mente. Você fica até zonzo. (...) Ficava, sabe, sem reação. Mas foi mais fácil. Eu acredito que se ela tivesse me enrolado, e depois falado, eu acredito que eu teria ficado com raiva dela. Sabe porque? Eu ia levantar e falar pra ela assim: 'não acredito, você me deu essa volta toda pra falar que eu tô beijada?' É uma gíria que a gente usa. 'Pra você falar que eu tô com o vírus?' Deu essa volta toda? Eu ia sair louca de lá de dentro, entendeu? Ia perder a noção com ela, no ato. Mas não, ela foi direta e ao mesmo tempo muito consciente, porque ela estava lá, assim. (...) Falei assim: 'então tá, e agora?' Só perguntei pra ela: 'e agora, o que eu tenho que fazer?' Era tudo que eu queria saber. Só que aí ela me explicou um monte de coisas. Ela falando e passando um filme da minha vida na minha frente..."

A aconselhadora "estava lá", ele contou. Com uma presença sustentadora e com disponibilidade genuína. Estabeleceu o contato com Bruno e aguardou, sem invadir seu tempo de "perder a cor", de ver passar "o filme da própria vida", de querer esquecer daquilo e de brincar usando o espaço potencial que foi assim constituído. Ele não a deixou ocupar todo o espaço e ela aguardou até que ele o fizesse ao seu modo. O brincar significa se relacionar, estar junto em mutualidade, 
em um espaço comum "de dois". Ela estava lá onde ele a colocou, como já disse WINNICOTT (1951) referindo-se à mãe que permite que o bebê a use. Há o entendimento de que a pergunta seguinte não será formulada: ele criou isto ou isto foi apresentado a ele a partir do exterior? Esse acordo tácito existe para que não haja a necessidade de responder a essa pergunta, pois o paradoxo deve ser mantido também aqui, como na concepção winnicottiana.

Por meio da criação dessa área intermediária não ameaçada, Bruno pôde usar seus próprios recursos (e os emprestados pela aconselhadora) para lidar com as ansiedades provocadas pela descoberta da infecção, que, no caso dele, transitavam entre a culpabilidade, a depressão, a confusão e o engano. Pois, uma vez que ele sabia e demandava de si mesmo e de seus amigos a prevenção do HIV, eram essas suas primeiras impressões. Esse espaço e tempo interligados pelo horror do que estava sendo anunciado podia ser transformado em algo da ordem do suficientemente bom e suportável.

Nesta seqüência de depoimentos, o de Bruno demarca aquele que expressa um aconselhamento mais atento às necessidades e desejos do cliente. A aconselhadora sempre esteve presente nas horas em que ele a requisitou.

A partir desse marco, iniciam-se outras versões: uma um tanto ambígua, mas positiva (a de Jonas) e as duas últimas notadamente negativas no que tange à vivência do processo de aconselhamento pós-teste (as de Paulo e Omar).

Jonas

Não era a primeira vez que ele recebia o resultado do teste, mas desta vez foi diferente, a começar pela atitude da aconselhadora. Já havia recebido o resultado por seu intermédio uma outra vez e, igualmente, já havia dela recebido informações sobre como se prevenir. Não tendo feito "sexo seguro" em todas as suas relações, infectou-se por meio de uma delas. Desse momento em diante, inicia-se a diferença identificada no seu processo de aconselhamento. Como já foi mencionado no ítem 4.2.1, Jonas se sentiu bem acolhido e ouvido. No entanto, no decorrer do seu relato, deixa transparecer um excesso de cuidado da aconselhadora para com ele, que termina por gerar nele uma angústia adicionada, a mais. 
Em termos psicanalíticos, excesso de satisfação ou de privação sempre é sinônimo de dificuldade e tensão produzidas no sujeito em determinadas circunstâncias. Para se desvencilhar delas e lidar com elas de forma satisfatória, o sujeito precisa retornar a etapas anteriores de seu desenvolvimento. Por meio desse processo regressivo ele busca consolo em ganhos (ou perdas) de outras experiências vividas. Assim, ele obtém os recursos que usa para servir de amparo na situação atual. É a vivência das experiências que lhe dá conhecimento necessário (por après coup) para lidar com as ansiedades que a situação atual mobiliza.

A quantidade de zelo por parte da aconselhadora, referida por Jonas, passa a ser vivida pouco a pouco como cobrança, responsabilização e culpabilidade, como ele comenta:

"Eu levei, tipo, na brincadeira, né, porque ela veio para mim e falou: 'Jonas, a gente tem que conversar sério'. (...) E assim, para mim, foi assim estranho, (...) o meu caminho lá da sala [de espera] até a sala de resultado foi um momento... Assim, meio confuso, eu não tinha entendido, foi difícil até... (...) Aí depois, a aconselhadora chegou em mim e perguntou: Jonas., você aprontou alguma coisa, né? E foi assim, até dura comigo. Assim, eu senti que ela foi seca, mais no sentido de dar uma bronca mesmo. 'Você aprontou e..' 'Você tá marcado, assim...' [Isso ela não disse, ele sentiu como se ela tivesse dito]. Foi difícil para mim. Não difícil pelo resultado ser positivo, assim... Acho que foi... Deveria ser uma coisa mais suave, não sei... Era aquela coisa... 'Você tem que contar o que você fez, porque que você está assim, porque... porque você, sabe?'

Jonas tem dificuldade de expressar seus sentimentos com relação a essa forma de revelação do seu resultado, demonstrando certa ambigüidade com relação a isso. Ele expressa sentimentos conflitantes:

"Sim e, ao mesmo tempo, não, [sobre sentir bem]... Pelo carinho que eu tenho com ela e vice-versa. Foi tranqüilo e ao mesmo tempo, aquela coisa... Dolorosa, né?"

Ele sentiu que a profissional daquele serviço foi muito carinhosa e percebeu o cuidado dela para com ele. Esse cuidado foi dobrado, a mais. Mas, ao mesmo tempo, o dobro de cuidado ecoou como uma cobrança: por ele já ter feito outros exames ali; por já ter recebido orientações de prevenção. Ele acha que por ser uma pessoa que já 
tem essas informações, deixou as pessoas daquele serviço sentindo-se confusas, talvez feridas em seu narcisismo de detentoras dos dispositivos de ensino da prevenção da doença. Porque não usou o saber adquirido? Porque se deixou infectar?

“Sabe?! Porque, sabe?'[Ele repete].(...) Sabe, é complicado, né. Deixei confuso o pessoal aí." [Ri]

E Jonas, como ficou?

"Não, eu assim, no primeiro dia, pra mim foi muito difícil, porque eu pensei: 'meu, comigo?' Sabe? Mas assim, hoje eu tô super desencanado. $\mathrm{Eu}$ acho que veio como uma coisa pra me dar um buum, assim, pra eu estar mais atento, pra eu estar mais ligado, pra eu fazer coisas que só estava no meu pensamento e agora já tá sendo colocado em prática, sabe? (...) Assim, isso foi positivo, assim pra mim, porque eu estou percebendo que eu estou crescendo com isto. Parei de beber, parei de fumar. Então, 'meu', foi super legal pra mim. Eu estou me sentindo melhor. É isso! (...) Então, o resultado foi para mim meio que uma surpresa, (...) me estranhou bastante o fato de ter [sido positivo, diferente das vezes em que foi negativo] (...). O engraçado é que ela foi meio severa comigo, meio dura e... Isso me deixou um pouco abalado no sentido de, não sei... Acho que poderia ser um pouco mais leve a abordagem."

Como Sílvio já havia apontado, também no caso de Jonas, o fato de o resultado ser dado por mulher é um complicador para ele. Sendo homossexual, teria preferido receber seu resultado na presença de uma pessoa também homossexual. A questão de gênero que surge e que parece interferir nestes dois aconselhamentos, suscita a reflexão a respeito de como minimizar as dificuldades da situação. Como já foi dito, todas as aconselhadoras são mulheres, portanto, não há uma maneira de viabilizar que a revelação da sorologia seja feita por homem, muito menos por um que seja homossexual. Mas, levando-se em conta que o resultado é técnico, e que requer preparo teórico-prático quanto ao instrumento, os efeitos podem ser atenuados. Resta solicitar ajuda de profisssionais dos serviços de referência, como sugeriu Silvio anteriormente. Jonas levanta a questão:

"O que eu sinto assim, não comigo, mas principalmente eu, que sou homossexual, e também pessoas hetero, eu acho que deveria ter, por exemplo, assim, tipo, segmentos... Por exemplo: num resultado positivo, ter um agente homossexual junto, (...) para a pessoa estar, de certa forma, fortalecida, porque muitas vezes a pessoa se sente muito sozinha 
recebendo um resultado positivo, (...) e tendo alguém que faz parte do mundo dela, acho que facilitaria bastante o pensamento... e até criar uma amizade (...). Porque é difícil, assim, acho que o usuário chegar numa técnica, que não vive nesse universo..."

O depoimento de Jonas parece ter sido relativamente bem sustentado (assumindo-se que o meio termo seja possível), com holding da aconselhadora e da instituição. Todavia, a sua dificuldade para tolerar a frustração pelo fracasso da prevenção fez com que o manejo na situação de aconselhamento fosse afetado. Houve, então, um dano em uma parte daquele ambiente facilitador, aquilo que proporcionou a Jonas sentir-se como se estivesse num divã (como referido no ítem 4.2.1). Em conseqüência da severidade apontada antes, Jonas sente que houve uma tentativa de invasão ao seu espaço interno. Ele sente isso de pronto e reúne os recursos de que dispõe para se defender. Desse modo, consegue estabelecer e usar a sua capacidade criativa e elabora seus próprios caminhos em direção à saúde: quando resiste a aceitar aquela ameaça ambiental e quando, em seguida, muda hábitos e retira novas provisões desse ambiente. Isso só foi possível porque teve tempo para voltar, para conversar, para argumentar e para ressignificar (capacidade de reviver uma experiência mentalmente dando-lhe novas significações). Foi ainda possível a Jonas imaginar, criativamente, soluções a serem incorporadas aos momentos de comunicação do resultado. O fato de estas soluções revelarem-se inviáveis não invalida o fato de Jonas poder criá-las, pois estará adicionando seus próprios objetos transicionais à situação geradora de ansiedade. Em outras palavras, o espaço para a simbolização da experiência traumática (ter o diagnóstico HIV positivo revelado) foi garantido. Seu processo de retomada da própria existência podia ter prosseguimento.

O processo de aconselhamento vivenciado por Jonas, no conjunto dos entrevistados, representa aquele que foi híbrido: tão suficientemente bom, quanto falho em relação ao ambiente. A sua versão de aconselhamento mostra também, que falhas podem ocorrer e, de fato, ocorrem. A mãe suficientemente boa winnicottiana só é suficientemente boa porque ela falha. E é só porque falha, que o bebê pode se desenvolver e se tornar ele mesmo, com seu próprio self. A mãe só se empresta a ele até que ele possa, só e por sua própria conta, tolerar a realidade.

O depoimento de Jonas representa também a transição para os sujeitos cujos 
aconselhamentos deixaram a desejar quanto à suficiência ambiental (incluindo tanto aconselhadores quanto a dinâmica institucional).

\subsubsection{Como se Processou o Aconselhamento de Omar e Paulo}

Esses dois entrevistados foram os que mais diretamente se expressaram contrários ao modo como foram colocados a par de seus resultados positivos. Por meio de trechos de suas histórias de aconselhamento, será notada a má impressão com que ficaram a respeito deste processo de revelação diagnóstica, designado por eles como: mecânico, automático, como um cartão eletrônico que se usa para digitar uma senha na máquina. Eles dão, com seus depoimentos, pistas sobre como o aconselhador pode se localizar nesse processo, de forma a não adotar uma posição de extremo afastamento ou falta, nem de excessiva intrusão. Todavia, suas versões de aconselhamento podem ensinar a vislumbrar os limites deste instrumento. Tais limites devem estar claros e definidos para o aconselhador, de tal modo que não se tenha a pretensão de instauração de um processo terapêutico, muito menos analítico. Contudo, os efeitos transformadores pretendidos quando ele foi criado e preconizado só podem ser obtidos se há escuta. Com uma escuta singular do sujeito, um efeito terapêutico pode ser deflagrado. Trata-se de um dispositivo que não foi desenhado para resolver questões de falhas na constituição subjetiva das pessoas que dele participam. Isso posto e estabelecido, não impede que se percebam e se identifiquem casos que necessitariam de outro tipo de intervenção psicológica, para além do espaço da comunicação do diagnóstico. Tais casos poderiam, certamente, demandar a ultrapassagem dos limites da própria instituição e o uso do sistema de saúde mais amplo. Talvez esse fosse o caso de Omar, como se verá mais adiante.

\section{Paulo}

"Eu achei que não aconteceria comigo. Entrei bem confiante e quando foi comunicado pra mim que o soro que veio era (...) reagente. Eu já sabia o que era reagente (...) Traduzindo o que é positivo, e não positivo popularmente conhecido. E aí eu vi que a pessoa falou assim: 'você sabe o que é reagente?'. Aí na hora eu já percebi que era positivo. Mas eu jamais pensei que eu fosse soropositivo. Eu vim com um colega e, no entanto, ele deu negativo e eu dei positivo." 
Paulo conta como foi o momento dessa comunicação, como foi comunicado o resultado a ele:

"Foi de uma maneira bem rápida, eu achei! Entendeu? Uma coisa automática, [foi] como você pegar um aparelho com controle-remoto e desligar, entendeu? Eu acho que foi bem... Automático. (...) A idéia que eu fazia de que o profissional fosse transmitir o resultado positivo ou negativo seja, fosse de que tivesse outra preparação... Um diálogo mais extenso sem muita correria, entendeu? Então, foi uma coisa assim que não durou cinco minutos... Perguntou os dados meus: sobre parceiros, essas coisas que eu fiquei até surpreendido também. Não dá pra você imaginar o que se faz durante dez anos! Dez anos é muito tempo! Para você... Como que você se relaciona com as pessoas, quantas pessoas já se passou na sua vida, entendeu? Mesmo o contato íntimo é uma coisa muito difícil para você se lembrar em dez anos. Quando você tem pessoas fixas, tudo bem, mas quando você tem aventuras, é impossível você prever quantas pessoas passam. Porque há pessoas que ficam e há pessoas que vão embora, que você apaga da memória... E foi menos de cinco minutos, [repete]. Não tô culpando o profissional; eu tô falando que a idéia que eu fazia da propaganda desse centro, quando o resultado tinha dado positivo, era que fosse uma coisa mais relaxante, mais preparada antes, não tão rápido assim, não tão automático. Mas aí é que está o lado do profissional que dava, porque pode ser que seja uma coisa totalmente diferente; eu sei que o profissional tem que saber diferenciar isso. Não sei se esse é o padrão da casa. Se é, tudo bem, mas pra mim foi muito, muito rápido... Eu que esperava sentar aqui diante do profissional... é... A preparação que eu tive lá embaixo, eu achei importantíssima a atitude da colega no dia do exame. Da profissional lá falando... Tinha coisas que eu desconhecia da doença... Eu tenho o hábito de ler e tudo, sabia? Mas tinha coisa que eu desconhecia. Coisas de hábitos que eu desconhecia que podia pegar a doença e... Diferente com relação daqui; daqui foi muito rápido... (...) A gente acha que nunca está [infectado]; a gente vem com essa esperança muito grande, tanto é que eu tenho uma segunda coleta, né?"

Ele recorda:

“(...) Falei assim: 'sei o que é reagente e não-reagente.' Aí eu olhei assim por cima pelo papel e vi: 'reagente' no resultado. 'Reagente significa', aí eu falei pra pessoa... 'Sei! É positivo!', virou assim e abaixou a cabeça: 'é positivo'. Só isso! Aí depois, eu preenchi os dados... 
É, não houve assim esse interesse de puxar diálogo que você tá puxando, entendeu? Então isso tem que ser trabalhado... eu acho, do meu ponto de vista. (...) Isso não foi trabalhado. Então, eu levantei aqui da mesa, fui lá embaixo fazer a segunda coleta e fui embora. A pessoa me tratou muito bem, mas acho assim: tem que ter uma garantia, uma preparação, se você quer saber. Anteriormente, independente do resultado ser positivo ou negativo. [Enquanto fala, bate com o dedo indicador na mesa]. As pessoas chegam aqui ansiosas, todas chegam ansiosas se é positivo ou negativo. Eu cheguei assim: cheguei cheio de... Super light! Aí saí daqui com uma angústia... Terrível! Não sentia as pernas, nem nada, como se tivesse no stand by, desligado a TV com o controle remoto. Na hora, a sensação que eu sinto é essa. E não sei onde fui, fui andando, pensando, olhando as coisas em torno de mim..."

Paulo repete as palavras que a aconselhadora usou:

“ 'Vamos descer para a segunda coleta?' Eu achei muito rápido! (...) Claro que eu posso chegar muito bem aqui e pegar o resultado, como meu amigo: 'escuta, eu não quero rodeio e eu quero tirar logo o resultado' é um direito que assiste a ele. Eu não!”

Este cliente sente-se frustrado, decepcionado. Tinha a crença de que aquele serviço de saúde estivesse melhor preparado para cuidar de sua dor psíquica. Não sabia direito como poderia ser feita essa preparação desejada, não consegue nem saber direito do que se trata. Porém, tinha esperança que o profissional soubesse e traduzisse a ele. Só sabe o quanto sofre, sabe o tamanho de sua angústia, tanta que transborda:

“Ah, essa preparação... Eu acho que cabe ao profissional que tá do outro lado da mesa... Pra isso ele estudou, pra saber como lidar com o psicológico. Então a pessoa que acha que vai estar tudo bem, não tá tudo bem; é difícil, é quem tá do outro lado pra isso que conhece os mistérios da mente muito mais do que o paciente. (...) Nunca fazer rápido; esperar que o paciente... escolha. Meu amigo falou assim: 'Olha, eu não quero muitas delongas, eu quero o resultado já'. Se o paciente chegar aqui, sentar e disser isso, é a escolha dele. (...) Cabe a quem está do outro lado da mesa já ir batendo um diálogo pra dar uma relaxada a mais, independente dele receber um resultado positivo - que nem eu recebipor mais relaxado que você esteja o baque vai ser forte, mas já adiantando uma relaxada, o certo ficou que é a primeira pessoa, a que confiou. Se eu estou aqui me abrindo com você, é porque eu confio em 
você... Você nunca [mais] vai me ver. Se eu tiver que marcar contigo, vou marcar contigo, mas, de repente, eu posso aparecer de uma hora pra outra, entendeu? E eu sou só mais um número só. Isso é bom para você levar em conta pra você se desenvolver, pra você cuidar das pessoas. Mas cabe a quem senta aqui! A que está do outro lado, eu acho que não tem que saber o... perfil psicológico de ninguém da primeira vez. Vai da maneira de apresentar as pessoas: de gesticularem, observarem, que é esse que eu acredito que seja o lado da psicologia. E perceber, ter a percepção rápida de como lidar com essa pessoa. Deixar à vontade se ela quer saber o resultado rápido ou se ela está muito ansiosa, dá uma relaxada nela se ela estiver muito tensa."

Esse relato de Paulo mostra como ele sentiu a ameaça de estar interditado o seu caminho em direção a ser, a existir para o outro. Um número é só mais um e não tem identidade, não tem vida distinta dos demais números. Paulo esperava que o saber técnico do aconselhador soubesse lidar com seus aspectos psicológicos. Mas o que parece ter acontecido é que o saber se concentrou no "técnico" e deixou de lado o "psicológico". A humanidade foi também retirada desta relação, segundo o relato de Paulo. Ele parece viver a própria desintegração. Mas de alguma forma se debate, esperneia e grita. E isso é saudável, porque seus gritos poderão - quem sabe? — ser ouvidos.

De acordo com ABRAM (2000), a desintegração é uma forma de defesa que parte do ser que é atingido pela falha do ambiente. Desintegração é o termo empregado para descrever a produção ativa do caos (por isso Paulo não sabe dizer como seria a preparação que aspirava, está tudo desorganizado em seu psiquismo). $\mathrm{O}$ caos se instala defensivamente contra uma ansiedade impensável (que não tem uma representação mental ligada a ela, nenhuma experiência que a re-signifique). Essa ansiedade impensável é resultante da falha do holding no estágio de dependência absoluta (o resultado do exame estava nas mãos da aconselhadora; ou melhor, Paulo estava nas mãos dela e ela não o segurava direito). $\mathrm{O}$ caos tem um sentido negativo se pensado em relação à falta de confiança no ambiente, mas tem a vantagem de ter sido produzido por Paulo. Nesse sentido, o caos faz parte de sua onipotência. Portanto, torna-se uma defesa. A vivência do caos foi necessária à sobrevivência de Paulo, pois o leva a buscar outras referências além das fornecidas naquele momento de intensa angústia. Ao menos pôde nomear esse sentimento; pôde sair de seu espaço 
psíquico individual; pôde, inclusive, projetar sobre a falta de preparação para dar a notícia; pôde transitar no espaço comum enquanto rememorava:

“(...) Não houve preparação; eu acho que houve um aceleramento muito rápido, tipo assim: 'eu tenho que atender outro, outro'. Não sei se o pessoal trabalha por números aqui. Porque no trabalho, às vezes você deixa o sentimento passar na sua frente e as coisas não funcionam assim, entendeu? Você entendeu o que eu estou falando? Então, você às vezes acredita muito numa coisa, você tá com um monte de gente que você quer ajudar, você quer, mas você vê que você não pode arrumar o mundo. Então tem coisa que você não pode, sabe, você tem que... deixar as coisas passarem. Então, assim, eu não estou aqui pra falar mal do trabalho das pessoas. (...) Eu saí daqui aquele dia... Nossa! Eu tava muito tenso! Eu achei que você podia... [referindo-se ao aconselhador] O cara ou a pessoa... O paciente que não tá preparado. Porque não vai mudar o que tá aqui dentro, o lado psicológico, emocional não vai mudar. Então, com quem você [o cliente] vai falar? Então você vai continuar pensando..."

Como foi analisado acima, Paulo não se deu conta de seu lugar na situação de aconselhamento, talvez exatamente pelo caos desencadeado internamente. Não se apercebe da potência que possui e insiste no preparo e poder do aconselhador. Insiste que é o aconselhador que tem a potência e preparo. Isso denota que Paulo esperava muito de seu aconselhador, talvez até de forma idealizada.

Quando a pesquisadora lhe pergunta: — você acha que dependendo da forma como essa conversa é feita, o sujeito pode cuidar melhor de si? Responde:

"Para alguém sair com aspecto mais ativo daqui? Depende de quem tá sentado aí... (...) Isso é muito importante. Eu só senti apoio porque ele [o amigo] estava aqui. Se ele não estivesse, eu vinha arrastando essa mochila do mesmo jeito, sabe, ia sair assim, desorientado."

É curioso que Paulo re-interpreta e traduz a pergunta da pesquisadora: "cuidar melhor de si" significa para ele "sair mais ativo" do aconselhamento. De alguma maneira, ele captou a essência da definição do instrumento de aconselhamento já expressa na introdução do presente trabalho: “...escuta ativa (...) visando o resgate dos recursos internos do cliente para que ele mesmo tenha a possibilidade de reconhecer-se como sujeito de sua própria saúde e transformação.” Pode-se supor que o efeito negativo (que ele relata que o aconselhamento provocou nele) não o 
impediu de perceber a existência de uma tecnologia de trabalho que pode auxiliar os sujeitos a se recomporem após o impacto da notícia. Mesmo não tendo sido isso o que ele sentiu no seu primeiro aconselhamento.

E quando é indagado se acha que poderia ter se sentido melhor se a conversa tivesse sido diferente, ele aponta para a duração cronológica da entrevista de aconselhamento, embora reconheça a dimensão subjetiva da categoria tempo e do próprio processo de aconselhamento:

"Mais prolongada, mais... Não tem que ter cronologia aqui dentro com esse tipo de situação... Não existe tempo cronológico. É isso! Tudo bem, existe uma agenda, mas se você tem que fazer uma pesquisa, para saber: trinta minutos é tempo suficiente? Quarenta? Ou cinqüenta? Fazer uma média... Quinze minutos não é o tempo suficiente a não ser que eu sente aqui como um paciente falou: 'escuta, sem rodeios, eu quero ver o resultado'. É suficiente! Mas quem está aí fora é instruído, tem uma preparação psicológica e tem estudo, um cidadão comum, eu sou uma pessoa comum. (...) Aquele dia que eu vim fazer o teste aqui, tinha um rapaz angustiado lá embaixo. (...) Aí eu pensei: 'nossa, não tem coisa melhor do que você tirar uma angústia de uma pessoa, você aliviar uma pessoa'. Não há preço pra isso! Entendeu? (...) Então, eu até falei pra ele: - 'calma, não sofra com antecedência'. E eu sou uma pessoa de sofrer com antecedência, mas eu vi nele, eu vinte anos atrás, porque eu tô com quarenta e pouco, eu me vi nele vinte anos atrás porque ele tava... Todo mundo que vem aqui, [nome da pesquisadora], não vem com a família... Vem só! E, sabe, vai depositar tudo o que sente em cima de quem está na mesa."

Ele não pôde depositar nem tudo, nem o que queria naquele dia, pois não havia lugar para colocar suas coisas. Ele não tratou de suas questões:

"Não, eu não tive essa oportunidade. Não, eu tive que me consolar com quem tava do meu lado, que foi meu colega que tava na outra sala. Ele saiu quando viu meu sorriso amarelo e falou assim: 'nossa, que sorriso amarelo'... Porque você tenta manter, né, eu tentei manter para ele. Ele estava ali e ele tinha sido chamado já."

O diálogo com Paulo prossegue. Procurou-se investigar se ele conseguia identificar quais eram os dispositivos necessários ao aconselhador para dar suportabilidade para a dor que sentia. Paulo pode reconhecer os limites do papel 
desempenhado pelo profissional, mas sustenta que o acolhimento da angústia que emerge nesta situação é algo fundamental e que precisa estar presente. A habilidade em acolher não pode faltar ao aconselhador, mesmo que não resolva o problema, mesmo que não o salve, como ele diz. Contudo, essa função precisa ser exercida. $\mathrm{O}$ cliente necessita sentir que pode depositar sua angústia, e que o outro a acolhe e sustenta. Trata-se, então, de constituir o holding e um ambiente de provisões envolvendo ambos, não só o aconselhado, mas também o aconselhador, formando a mutualidade.

Paulo experimenta o sofrimento pelo seu resultado positivo, mas também pela forma como esse the foi comunicado. As ansiedades persecutórias afloram, deixando-o desamparado e revoltado. Tem muitas questões, e, ao fazê-las, busca, ele próprio, as respostas, ensaiando as soluções para o funcionamento da instituição. Parece ter tido tempo para observar o fluxo e o dinamismo institucional e, se existir alguma intenção de mudança, é imprescindível que sejam ouvidas suas hipóteses e sugestões:

"É isso que eu tô até falando contigo: eu não queria que ninguém passasse o que eu passei... Não comunicado assim. Se vocês puderem mudar isso seria ótimo. Não dá pra entender como é que se trabalha pra fora; aí já estou querendo entrar numa área que não é minha. Mas assim: como lidar com as pessoas? Não pode ser assim como um cartão de banco 24 horas. Por pior que seja o indivíduo, você não pode lidar assim... Então, eu não estou te falando que a profissional é ruim, não estou jogando a culpa em cima dela. (...) Eu acho que teria que dar um tempo pra pessoa que tá aqui digerir o resultado. Se ele for negativo, a pessoa vai digerir, já vai engolir; se for resultado positivo, a pessoa que tá aqui já abriu o envelope, já sabe... Quando pega lá dentro. Eu tava observando... Eu observo tudo aqui. Quando pega naquela sala. Chama pelo nome, tem o código, então se ela sabe que é soropositivo, tem que dar um tempo pra pessoa digerir aquilo. Tem gente que não sabe se chora ou se descabela aqui, eu gelei! Porque eu achava que eu não era soropositivo. Eu gelei! Falei: 'a minha vida acabou'. Então, quem tá aí já sabe qual o resultado. Quem dá negativo, engole super rápido, digeriu... Quem tá positivo, fica com o questionário sempre pode acontecer isso. Responde o questionário. 'Ah, tá'. Eu levantei. 'Vou fazer a segunda coleta, tá?' 'Tá bom'. É uma confirmação? Falou: 'É'. E desci para fazer a segunda coleta. Não deu 10 minutos, se você quer saber. (...) Tem que 
dar um tempo pra quem o resultado é positivo... pra pessoa digerir aquilo. Porque ela vai estar sozinha (...). Ninguém vai vir junto aqui... (...) Ninguém nunca tá preparado pra isso. A gente sabe que a gente vai morrer, mas nunca tá preparado. A gente sabe que acontece com os outros, mas ninguém quer receber uma notícia dessas... Entendeu? Quem está aí, está cheio de esperança do primeiro resultado. Eu tenho esperança do segundo resultado? Tenho! Seria bom se você pudesse falar 'escuta, vai dar...'. Se bem que eu acho que no meu íntimo eu acho que, que isso é... eu não entendo porque vem a segunda coleta. Porque se é um teste bem conceituado, então por que a esperança que dê negativo?"

Ele indaga, ainda, se existe um trabalho de acompanhamento "a sério" para as pessoas lidarem com o resultado. E define o que está chamando de "a sério":

"Se eu começar uma coisa [atendimento] com você, eu tenho que terminar com você. Eu sou contra esse negócio de passar uma coisa pro outro, de começar com um profissional e terminar com outro. Eu não acho isso correto, principalmente numa situação dessa. Acho que se eu começar uma conversa com você, eu tenho que terminar contigo. Não adianta passar pra terceiros, fica uma coisa incompleta. Você vai pegar o bonde andando... Por mais profissional que você seja. Eu falo no sentido de que... As pessoas precisam ser ouvidas na hora de dar o resultado. Às vezes eu me desligo. [Sem ficar pensando no resultado positivo] Tanto é que eu estou aqui hoje e me desliguei. Mas quando eu estou em casa sozinho, minha cabeça fica a mil. É isso que precisa ser trabalhado. Não vai dar a solução para mim, mas talvez algumas pessoas precisem mais. Não tenho ninguém no mundo pra dizer: 'o que eu vou fazer da minha vida'... Pra quem falar..."

Paulo sugere a necessidade de algo a mais, de um atendimento seqüencial, que pode (ou não) estar ligado às funções desempenhadas pelo CTA, de acordo com a complexidade de sua demanda. Com quem vai falar se precisar? Não lhe ocorreu na hora do aconselhamento perguntar isso para a aconselhadora, ele já concluiu que ali não dá para fazer mais nada:

"Porque eu achei que o contato terminou com essa área ontem, é o resultado. Não sei se existe um acompanhamento, entendeu? Só existe o resultado aqui. Porque, pelo que eu estou vendo, estou percebendo, esse aqui é o local pra você dar o resultado, esse é o atendimento junto com o resultado. Não vai ficar perdendo tempo, para poder falar com pessoas que já têm o resultado positivo, vindo duas, três ou quatro vezes. Existe 
um local específico pra isso. (...) Assim, bom, 'eu sou soropositivo, eu estou necessitando conversar com alguém'. Mas será que vai ter esse espaço físico aqui, pro pessoal trabalhar? (...) Quantas pessoas passam por aqui? E vão sobrecarregar elas?

Essa última colocação é bastante parecida com a de Sílvio no início: não querer ocupar o tempo, pois pode ter mais gente esperando. Ambos sentem-se destituídos de seu lugar, deslocados, ocupando o espaço que acham que não é deles. Pode-se indagar: se não é deles, de quem é então? Para quem foi formulada a política de testar e aconselhar? Não foi para o público que acorre aos serviços? Eles não são público? São sim. Não um público anônimo. Ao adentrar o CTA, passam a ser pessoas e, sendo pessoas, têm que se tornar o "outro" para quem os atende. É importante que o espaço compartilhado seja constituído. Mas para isso precisa de tempo. Precisa também de reconhecimento deste outro. Por essa razão, Paulo se refere a poder ser atendido duas vezes pela mesma pessoa. Por isso, ele sinaliza se a pesquisadora vai falar com ele ou se será outro profissional. Essa pergunta denota mais uma vez a boa condição defensiva apresentada por ele. É titubeando que ele o faz, mas ele marca sua posição subjetiva. Mostra que está vivo, lutando contra a ansiedade relacionada ao seu resultado positivo, e à forma como esse lhe foi transmitido. Continua com seus questionamentos:

"Ou existe um profissional só: a profissional que vai comunicar, é a profissional que vai conversar? E se eu chego: 'a profissional que eu quero conversar é essa daqui'? Se tem preferência pelo mesmo paciente... Porque aqui não existe. Geralmente é a equipe médica que tem o paciente, né? Cada um na sua equipe tem o número do paciente ou se o pessoal que trabalha aqui faz esse vínculo? Não sei se isso tem; não sei como funciona lá embaixo. Ou se é aleatório, ou não. Como você, eu não veria outra pessoa. Se você não viesse hoje, eu não veria qualquer outra pessoa no lugar..."

Ao mesmo em que Paulo teorizava buscando explicações para suas inquietações, ele manifestava sua posição em relação à segunda entrevista de pesquisa: não faria com outra pessoa. Era a sua maneira de se reassegurar, de não tolerar mais frustrações, de evitar ser preterido (ou abandonado). Ele já disse que vem sozinho ao serviço e não ter a mesma pessoa para atendê-lo é algo que não vai suportar. De certa forma, ele tenta garantir a manutenção do setting em sua 
materialidade: mesma pessoa, horário combinado e escuta providenciada.

"Na segunda [comunicação do resultado] eu senti que... Não mudou muita coisa não. A atenção veio depois do comunicado. $\mathrm{O}$ interesse veio depois do comunicado de que tirasse as dúvidas. Pra quem tá do outro lado da mesa é normal dar o resultado pra tanta gente, positivo ou negativo. É uma coisa comum. (...) Eu também não sei se, às vezes eles podem estar chateados porque são mal remunerados, ou é descaso total. (...) Porque o fato da pessoa ter um nível superior, não significa que tá preparado pra tudo. Inclusive existe congresso, esse pessoal tem que estar se atualizando, tem gente que se forma e para no tempo... E a diferença daqui é que quem trabalha aqui está lidando com gente.”

Paulo potencializou seus recursos na direção de se defender contra as ansiedades emergentes na situação de anúncio de seu resultado de teste. Desse modo passou por ela. É uma situação que pode ser chamada de traumática. Essa denominação se insere em um duplo sentido: pelo resultado em si positivo para uma doença ainda incurável e pela experiência adversa de ser aconselhado da forma como descreveu. A experiência relatada evidenciou falhas no ambiente em relação às quais este cliente apresentou defesas. As defesas possibilitaram a ele manter-se em suspenso na situação a fim de, em seguida, buscar as explicações para aquele funcionamento institucional. Foi possível, depois, iniciar um movimento em direção a uma elaboração mental, mesmo que precária a princípio. Com isso obteve sua própria compreensão da notícia revelada.

\section{Omar}

"Bom, o resultado foi um pouco difícil, assim, né? Ela foi anotando alguns dados, tal e aí você fica um pouco naquela apreensão, né? 'Dá logo, né? Já fala logo pra não ficar com rodeios'. Embora eu acho que... é... pra você dar uma noticia dessa, que eu sei que é complicado, você tem que... é... eu acho que tira um pouco da parte do administrativo, porque você tá lidando com uma pessoa. Depois que você deu a notícia, enfim, aí você vai cuidar da sua papelada. Entendeu? Sabe fica aquela coisa meio mecânica. Meio não, totalmente mecânica, né? Eu vim aqui, você que vai dar a noticia pra mim, certo? Então você tem algumas partes que você tem que preencher, né? Que faz parte do processo. É... só que antes de mais nada é uma pessoa que está ali, né? Então: 'oi, tudo bem?' [sugere que se diga] E tal, né? Isso até foi perguntado por uma questão de 
praxe, assim. Foi esse meu sentimento. Se a pessoa [que recebe o resultado], não tem uma estrutura... É, porque você já vai meio preparado, (...) para um sim ou não. Mas ela sempre quer a parte positiva, né, que nada vai acontecer, enfim. (...) Na hora eu tomei um baque, tentei ficar bem pra não transparecer, pra pessoa que tava me entrevistando. Acho que devia ser uma autodefesa, enfim. (...) Eu vou traduzir, mostrar pra você o que aconteceu na situação. [Faz uma simulação:]'Oi Omar, tudo bem?'. 'Então, pois não, tá tudo bem com você?'. 'Tá, tá tudo bem.' 'É... então eu vou fazer algumas perguntas pra você.' E aí ela começou a preencher os relatórios dela. E aí o resultado estava dentro do envelope, tá? E aí, então, ela (...) 'A notícia que eu tenho pra lhe informar não é muito boa, né. Realmente você deu sorologia positiva.' Eu: 'tá bom.' Aí ela: ‘tudo bem?'. Eu: 'ah: tudo bem' não é tudo bem, né, enfim. Aí ficou aquele silêncio, né? Aí ela fez alguns questionamentos, mas assim, que eu já nem lembro mais, (...) Como eu acho que não houve uma preparação, pra você dar a noticia, porque se preocupou em preencher os documentos administrativos que faziam parte do processo, então qualquer pergunta que se fizesse ali em relação ao meu sentimento, ali já não era mais válido. Aliás, não surte nenhum efeito. Entendeu? Por mais que você tente confortar a pessoa, não vai surtir nenhum efeito, né? (...) Não tornar a coisa muito seca ou então... É... Mais um. Entendeu? Assim... Uma coisa corriqueira. Porque todo dia você [referindo-se ao aconselhador] faz a mesma coisa, então você acaba perdendo a sensibilidade. É isso que eu senti. E isso é natural do ser humano. Eu até entendo um pouco isso, mas você, eu acho que você sempre tem que estar se reciclando, pra você não passar essa imagem que foi a minha percepção. (...) Você sabe o que eu acho? No primeiro contato a pessoa que passou a informação, ou me parece que ela não é da área, ou então esqueceram e eu não sei de que área que ela é. Enfim, eu acho que ela é uma profissional... Acho não, ela é uma profissional capacitada e por isso que ela estava ali para passar a informação pra mim. Mas assim, ela foi muito automática. Então assim, ela já está acostumada, eu já até falei isso, né? Ela já está acostumada a fazer isso e ela não se deu conta de como ela tá fazendo a coisa. Entendeu? De como ela está sendo automática. (...) A minha impressão naquele momento é que, eu era mais um. Eu era um ser humano ali!"

Omar está em um espaço que não tem nem manejo nem holding e, desta forma, não se pode constituir uma mutualidade, o espaço compartilhado que é seu, mas que também é do outro. Então, Omar se fecha ao contato a partir de um ponto de 
seu aconselhamento:

“... não queria que ela invadisse mais nada da minha vida. Eu não queria que ela tocasse mais no assunto e... Ponto final! 'Vamos encerrar aqui, não quero ouvir mais nada'. Então aí eu fiquei quieto, ponto!"

Omar sentia que a aconselhadora invadia... No entanto, a imagem que ele desenhou a respeito dela, anteriormente, era a de uma aconselhadora totalmente ausente. O espaço entre os dois encontrava-se vazio e não totalmente "empossado" (no sentido de ocupado sem permissão do dono).

A análise a ser desenvolvida com relação ao processo de aconselhamento de Omar associa-se mais à hipótese de que ele tenha um funcionamento psíquico prejudicado em suas origens. A sua reação à comunicação do resultado é de retraimento, de retirar tudo de si do espaço de comunicação, exatamente como conta que foi feito pela sua aconselhadora. A impressão é a de que os dois estão fora e, então, não há área de intersecção entre seus mundos. Nada pode ser significado onde não há acontecimento. Não existe um processo de comunicação em curso. São duas paredes opacas que não refletem nada. Não tem ninguém transitando por ali.

De alguma forma, a segunda aconselhadora que falou com ele, conseguiu fazer um laço com algo de seu espaço interior. Ele próprio tenta levantar as hipóteses para encontrar as razões disso:

“(...) $\mathrm{Na}$ segunda vez que eu fui, que foi o dia que fui indicado [convidado a participar da pesquisa], a pessoa que me colocou conversou comigo e tudo mais, me pareceu ter mais sensibilidade, né? Acho que ela tinha até um pouco mais de idade em relação à primeira pessoa, então eu senti um pouco mais acolhido, né? Mas eu já sabia do resultado... (...) Bom, o segundo foi a confirmação, já estava preparado e teve toda a documentação de novo, todas mesmas perguntas e tudo mais. Aí depois se abriu o envelope, então realmente veio a confirmação, tudo bem. Assim, pelo jeito que ela colocou, eu achei que eu era mais acolhido ali naquele momento. Foi esse meu sentimento, né? Às vezes isso vai também de empatia, eu acho também um pouco disso, vai de como você está naquele momento, né? Aí assim, fica aquela dúvida, né? Entre a primeira pessoa que me atendeu..., será que eu estava muito com medo, ou então eu não estava preparado, e enfim eu acabei bloqueando tudo isso e não ouvi nada do que ela falou, e aí estou tendo uma má impressão 
da pessoa que me atendeu? Mas aí eu acho que assim, é muito de sentimento mesmo, você perceber isso, a pessoa transmitir isso pra você, entendeu? Porque assim, se você... Da forma que você coloca [referindose ao aconselhador], você conduz e aí você traz a pessoa, ou você não traz, você distancia, né? Enfim... Você perde a pessoa."

Como já foi dito, no segundo aconselhamento Omar teve as informações sobre os dois projetos de pesquisa, dos quais por pouco não participa, podendo ter acarretado uma oportunidade duplamente perdida: a individual, na qual ele próprio se beneficia sendo ouvido e tratado, e a coletiva, na qual os benefícios recaem sobre a sociedade e a ciência. Omar relata como os projetos lhe foram propostos:

"Acho que era tanto documento que eu tinha que assinar nessa segunda vez, e os encaminhamentos... (...) Do jeito que ela me colocou toda aquela papelada, aquele mundo de papel, ela foi me perguntando, 'olha, a gente tem esse trabalho, tal, na [nome da instituição responsável pela outra pesquisa]. Você quer participar? Oh, é assim, assim, assado'. Só que é um monte de papel pra preencher e tudo mais. 'Legal'. É... aí eu estou lembrando tudo que aconteceu. E aí foi muito legal isso, porque ela explicou, e aí... 'Não, Omar, então, e aí? Bom, é assim. Tudo bem, Omar?' 'Tudo bem.' 'Então a gente vai ler junto tal, como funciona...' (...) Sabe, assim, como você se sente, pegar no colo mesmo, que nem criança, não que eu seja, mas enfim. E aí, explicou "tim-tim por tim-tim". Aí depois veio a segunda parte: 'Olha, a gente tá com uma pesquisa, tal, tem uma psicóloga lá, lá, lá, lá, lá, lá... E que aborda, tal.’ Falei que sim... Aí explicou tudo bonitinho. Aí mais papelada. (...) É porque as coisas são muito burocráticas, né? Assim, algumas coisas não têm, não dá, não tem como fugir, né? Não tem como fugir. E também se você não fala com a pessoa ali: ah vamos marcar... Se você está afins, vamos marcar outro dia, a pessoa não vai voltar, né? Tem esse outro lado da moeda. Então você pára pra pensar que você tem que, então, é, então tem tudo isso, a gente não tem como fugir disso. Ponto. Legal. Então, como fazer tudo isso e tentar, é, dar uma base pra pessoa, porque a pessoa está muito mal ali. Como fazer isto? É você com a simpatia, é você sabendo colocar de uma forma legal pra pessoa, entendeu? É, tomar esses cuidados que são muito decisivos na hora que a pessoa vai optar ou não, por fazer ou participar, enfim, " $n$ " coisas, entendeu?

O que precisa ser escutado naquilo que Omar manifesta é o que se refere à sua humanidade. É o que vai permitir que os espaços de aconselhamento sejam 
settings constituídos intersubjetivamente de forma verdadeira, para funcionar como realidade compartilhada. Enfim, com seu relato (e o dos demais entrevistados) pode se construir a imagem e a história de quem é esse sujeito e do que ele demanda do aconselhador. No caso de Omar, ele demanda muito mais do que o espaço de revelação do diagnóstico do HIV pretende oferecer. É por essa razão que ele fica tão insatisfeito. Mas, a experiência verdadeira é a que mostra o que não se pode fornecer, sem que haja necessidade nem de se ausentar, nem de ser intrusivo.

Foi observado nos vários relatos que, na revelação do diagnóstico, o cliente volta-se para as experiências vividas, tentando, por meio das lembranças, identificar qual delas lhe trouxe a esta situação atual. Imaginariamente, ele tenta iluminar alguns encontros e ocultar outros, já que a situação implica certa negatividade, que se associa às suas vivências emocionais pregressas, tanto as mais antigas quanto as mais recentes. Assim, bons e felizes encontros podem ficar preservados, num primeiro momento, enquanto que experiências desagradáveis ou mesmo escusas podem vir à tona, e vice-versa. O espaço potencial, no qual os objetos e fenômenos transicionais circulam por meio da transferência e contratransferência, só poderá se constituir se a abertura e sustentação forem dadas por quem participa do aconselhamento. Por meio do manejo e do holding, o aconselhador apresenta o resultado na medida em que o cliente possa suportar essa realidade. Porque, a partir daí, a simbolização pode vir a acontecer... É preciso que a situação presente faça sentido, tenha um registro no psiquismo, e isso só será possível se o indivíduo pode incluí-la em sua vida vivida, passada, que agora é chamada a fazer elo com o momento presente, configurando, prospectivamente, o que será vivido no futuro. As associações são do domínio do cliente, do seu próprio mundo. Para que esse caminho se trilhe, favorecendo esse acontecimento, há necessidade do manejo da situação de interlocução (ou intersubjetiva) por intermédio do fenômeno da ilusão e seu complemento, a desilusão. A ilusão se apresenta por meio da manutenção da onipotência, necessária ao armazenamento de recursos e provisões. Analogamente, a desilusão opera pela apresentação do princípio de realidade. No caso do HIV, isso se traduz como algo temível e com freqüência associado, simbolicamente, a imagens destrutivas e significações mortíferas.

Sintetizando este capítulo, pode-se considerar que os clientes entrevistados, 
no momento da comunicação de seus resultados, eram como o bebê winnicottiano construindo seu objeto subjetivo. Tal como o bebê com sua mãe, nesse processo de construção de ser, é o cliente que "diz" por onde a aconselhadora pode caminhar. Ele "diz", ainda, quando ela pode se aproximar e quando deve se afastar ao cumprir sua tarefa de colocá-lo a par de seu diagnóstico. Ao mesmo tempo, ao fazer esse caminho traçado pelo cliente, é a aconselhadora que o coloca no caminho dela (do diagnóstico a ser transmitido).

Por essa razão, WINNICOTT (1951) aponta para a existência de um paradoxo no trânsito do desenvolvimento do bebê na relação com a mãe. Esse paradoxo foi observado muitas vezes nos relatos, nos quais se pôde perceber que nada é inteiramente ruim ou bom. Não há a boa receita do bom aconselhamento. De maneira simplificada, o aconselhamento é suficientemente bom (assumindo-se que falha) quando ele sustenta as angústias dos clientes e facilita a retomada de suas vidas. 


\section{CONSIDERAÇÕES FINAIS}

"Cada ser humano tem uma posição diferente, tem um lado emocional diferente, tem um psicológico diferente..."

Paulo, solteiro, 40 anos

A frase de Paulo ilustra o que precisa ser capturado nos processos de aconselhamento sorológico. Com esse objeto em foco, cada cliente poderá ter seu lugar assegurado no momento da comunicação do resultado do teste anti-HIV por meio da presença concreta do aconselhador. Muitos entrevistados sentiram a disponibilidade e o cuidado de suas aconselhadoras.

Ao relatarem suas histórias, eles ensinam coisas que eram, se não sabidas, já recomendadas aos aconselhadores e serviços de saúde. Por essa razão, inicia-se este capítulo (re) colocando recomendações formuladas a partir da experiência de escutar estes clientes falarem sobre a revelação de seus diagnósticos.

Quem vai ao CTA realizar o teste anti-HIV mais de uma vez tem a oportunidade de se familiarizar com o funcionamento da instituição e com os profissionais. E, mesmo clientes que realizam o teste pela primeira vez podem vivenciar uma relação de proximidade com a aconselhadora na revelação de sua primeira sorologia negativa. Assim, a prática de uma mesma aconselhadora dar o resultado para clientes que realizam mais de um teste pode ser uma lógica a ser adotada. Esta prática pode facilitar a reflexão com o cliente sobre as suas dificuldades de fazer prevenção que determinam sua exposição ao risco de infecção com certa freqüência (como já mencionado na Introdução). Um dos entrevistados teve essa experiência e a considerou proveitosa. A razão apresentada por ele diz respeito à intimidade e confiança que se estabeleceu entre si e a aconselhadora, e que foram necessárias ao compartilhamento de situações delicadas que não poderiam ser tratadas sem essas condições. Esse estreitamento da interação aconselhador-cliente pode ser uma via para fortalecer a intenção de aderir ao tratamento, uma vez que o estabelecimento da confiança é o que faz com que se acredite em ensinamentos, recomendações e prescrições. 
O tempo que se leva para ir ao serviço de encaminhamento é livre e dependente do ritmo de cada cliente. A dosagem de afirmação dessa necessidade está condicionada ao nível de ansiedade e de motivação para iniciar o tratamento. A adesão ao tratamento é fundamental, mas ele precisa ser entendido pelo cliente como imprescindível. Se ele não tem inclinação para aceitá-lo, dificilmente poderá se manter no tratamento, mesmo que o inicie. O acolhimento da outra unidade é um ponto que favorece a entrada do paciente ali. E pode haver uma diminuição da distância que separa o aconselhamento e o serviço de referência, mas esse é um desafio a ser transposto. $\mathrm{O}$ caminho pode ser mais bem ligado, para que o cliente não se perca nele. Ele tem que ter tempo para iniciar e continuar o percurso, e, às vezes, “já” não é a melhor hora para ele.

Uma recomendação que pode ser útil e compreensível é o exercício da abordagem dos assuntos relacionados ao vírus, à doença e ao tratamento de uma forma técnica, mas não prolixa e complicada. É um treino necessário, uma vez que os clientes são leigos e nem todos têm alto nível educacional. Os clientes repetem o que é dito a eles e, às vezes, podem não saber exatamente o que aquilo significa. Então, é comum ouvi-los mencionar termos biomédicos, nem sempre de fácil compreensão, relacionados ao conteúdo informativo que lhes foi apresentado. Uma linguagem acessível facilita a assimilação das implicações do resultado e do encaminhamento para as prescrições necessárias.

O cuidado com o ambiente físico da instituição, desde a placa da entrada até a organização dos setores de atendimento, é importante para que o usuário não se sinta prejudicado na garantia do sigilo do seu diagnóstico. O mesmo se aplica aos comentários dos profissionais em espaços compartilhados com os clientes nos serviços.

$\mathrm{O}$ cuidado com o ambiente diz respeito, também, às razões estéticas e de conforto. A instituição não precisa ter um ambiente austero para ser séria e competente. Um ambiente agradável, com controle de ruídos e sons, com uma decoração sóbria, mas que favorece o bem-estar, é o primeiro passo para o cliente sentir-se acolhido. 
Empatia é uma condição necessária ao alcance de objetivos do aconselhamento. Os clientes entendem que as aconselhadoras só poderão se aproximar dos seus sentimentos e percepções, com relação ao resultado do teste, se tiverem a capacidade de se colocar no lugar deles, como se fossem elas próprias que estivessem recebendo aquele resultado.

O mesmo se aplica à oferta de preservativos, que não pode ser invasiva, ostensiva, nem com julgamento de valor sobre a quantidade dos mesmos. É ótimo para o controle da epidemia que se tenham preservativos sempre à mão, mas a escolha de quantos eles serão, só pode ser feita por quem os vai usar. Ao receber o diagnóstico, os clientes podem vivenciar a paralisação (ou congelamento) do desejo sexual por algum tempo. Seus afetos estão voltados para si mesmos, para o seu interior, em um processo de elaboração mental do trauma (no sentido winnicottiano de quebra da continuidade da existência). Isso é temporário e se manterá até que ele possa novamente dirigir seu desejo aos objetos externos. Pode-se ter o cuidado de fazer uma pergunta que não pode ofender nem magoar: "você gostaria de levar preservativos hoje?” A resposta só será verdadeira se for livre.

Uma análise dos efeitos da entrevista com os clientes também se justifica, por que algo ultrapassou os limites da pesquisa. A entrevista, como contexto intersubjetivo, também produziu seus efeitos e foi interventiva. Esses efeitos foram apreendidos por meio de alguns relatos, mas alguns sujeitos manifestaram-se a este respeito, explicitamente, na segunda entrevista. Questões que emergiram durante e após a entrevista de pesquisa foram colocadas, funcionando, de certa forma, como extensão do processo de aconselhamento porque: foi realizada no CTA; a pesquisadora era psicóloga de formação, e a "conversa com a psicóloga" foi o atrativo ou apelo para alguns; puderam falar e ser escutados; e puderam ressignificar experiências e conteúdos, o que permitiu a compreensão e transformação de algumas questões.

No caso específico de um cliente (Milton), observou-se que o tempo transcorrido entre a revelação do diagnóstico, a primeira entrevista da pesquisa e a segunda tiveram o efeito de movimentar as suas emoções relacionadas à soropositividade. As defesas dele foram se enfraquecendo. A princípio, quando entrou 
em contato com a revelação do diagnóstico, utilizou um mecanismo semelhante à projeção, espelhando na aconselhadora seus sentimentos de tristeza e angústia, dizendo-se preparado para a notícia e a aconselhadora, abalada e tristonha. Entretanto, à medida que o tempo transcorria e a realidade se apresentava mais e mais, seus verdadeiros sentimentos, principalmente relacionados à perda da condição de integridade do sistema imunológico foram se manifestando. Então, nesse momento, começou a entrar em contato com o próprio sofrimento. Isso ocorreu de uma forma intensa, transparecendo durante as entrevistas da pesquisa, especialmente na segunda, quando não consegue manter a versão de que já esperava o resultado e que está tudo bem. Está visivelmete emocionado. Por essa razão, a pesquisadora the indagou se uma ajuda psicológica não seria recomendada, o que foi prontamente reconhecido e aceito. $\mathrm{O}$ encaminhamento foi providenciado, então, pelas aconselhadoras do CTA.

Como se observou em seus relatos, os clientes foram ouvidos e reconhecidos pelas aconselhadoras. Sentiram-se colocados em um mundo compartilhado de verdade, no qual eram o centro de interesse daquela ação de saúde. Isso mostrou que uma consulta, mesmo que única, produz efeitos subjetivos favoráveis e até mesmo terapêuticos na vida das pessoas.

WINNICOTT (1941, p.159) sugere que o que é terapêutico, quando se possibilita a forma de trabalhar denominada consulta terapêutica, é o fato de ser permitido o desenvolvimento completo de uma experiência. Houve casos em que isso se deu.

As equipes de profissionais mostraram (na voz de seus clientes) que podem apresentar um ambiente que tenha uma função de holding, provendo uma escuta que possibilite ativar recursos do sujeito atendido e possa sustentar suas manifestações diante da revelação de seu resultado. Para isso, é necessário que cumpram uma função intermediária. Que estejam dispostas a criar — ou a percorrer — um caminho comum e mútuo, entre ambos, a estabelecer uma ligação, a dar voz e a poder ouvi-la, a fazer falar e saber calar, a ouvir o silêncio e falar a palavra que ecoe e seja significativa.

A base para o enlaçamento nesta situação específica e para a formação dos 
agrupamentos humanos é a ilusão, segundo WINNICOTT (1951). Ao longo do presente estudo, já foi mencionado que o estado de ilusão no bebê é o de apropriação progressiva do mundo externo. Nesta progressividade, o bebê faz o seu percurso de experimentação na área intermediária, para a qual contribuem tanto a realidade interna quanto a vida externa. Já no adulto, essa área de compartilhamento encontrase na arte e na religião, nas quais existe similaridade entre as experiências ilusórias. São as experiências que trazem o lado subjetivo do ser humano, que realizam o trânsito entre o interno e o que é objetivamente percebido. Com a apropriação dessa teoria, a reflexão ora realizada, no contexto do aconselhamento, chega ao seu termo. O percurso que se fez permite algumas considerações finais, ainda criando derivações para este outro contexto.

No caso do aconselhamento, cliente e aconselhador são, no princípio, indiferenciados um para o outro, como também acontece com a dupla mãe-bebê winnicottiana. Isso se modifica aos poucos, quando algum processo de comunicação se inicia. A condição para que o processo de diferenciação ocorra é a existência de um ego, uma instância psíquica capaz de oferecer defesas contra as ansiedades provocadas pelo momento.

É uma oportunidade privilegiada de preencher a palavra com a dimensão humana - por mais estranho que isso pareça, já que quem a pronuncia é um ser humano - , de não deixá-la vazia de significado.

Lidar com seres humanos é uma tarefa onerosa e gratificante. Onerosa por ser uma experiência, e como toda experiência, ela vai se construindo na medida do seu acontecimento. Portanto, é dotada de certo grau de angústia, a angústia do desconhecido ou do não saber. Gratificante porque, quando tornada acontecimento, tornada verdadeira, traz conseqüências poderosas para as pessoas envolvidas. Dota de sentido o face a face entre seres humanos. Quando não é algo repetitivo, automatizado e numérico, promove o crescimento, o amadurecimento, a melhoria do humano em sua humanidade. Traz o bem-estar, a possibilidade de enfrentamento do sofrimento, das limitações, das perdas. Assim, considera-se que cabe um pensar sobre como tornar a revelação do diagnóstico de uma doença crônica, estigmatizante e incapacitante como a aids, um acontecimento. Ou seja, o acontecimento é o próprio 
momento dotado de significação para os envolvidos — aconselhador, cliente e demais membros da instituição e da família. O acontecimento constitui-se no movimento de trânsito entre um e outro - no espaço e no tempo - no percurso e na experiência compartilhada. Não é uma magia ou milagre que num estalo aparece. Isso não. Mas é sim, um olhar. Um olhar que possibilita o encontro. Um encontro que torna possível a continuidade da existência, do ser, vislumbrado e enaltecido por WINNICOTT (1975): “... como expressão do EU SOU, eu estou vivo, eu sou eu mesmo" (p. 83).

Esta reflexão sobre a investigação, cujos dados, colhidos fora dos limites da clínica psicanalítica, produziu resultados que lançam um pouco de compreensão sobre a complexidade e a singularidade dos atos inter-humanos (conforme LOPARIC, inspirando-se em Heidegger - Comunicação pessoal na aula ministrada em 19/10/2001, no Núcleo de Pesquisa Psicanálise e Sociedade da PUC-SP). Os resultados podem também servir de suporte ao campo do aconselhamento no âmbito dos CTA investigados, cujos profissionais poderão sentir-se notados e reconhecidos por meio da parte de seu trabalho ora analisada.

As experiências narradas pelos clientes entrevistados mostraram em seus aspectos manifestos e latentes que, nos dois CTA em que eles receberam a revelação do diagnóstico, às vezes a aconselhadora funcionou como a mãe suficientemente boa winnicottiana, às vezes não. Em alguns aconselhamentos houve a criação de um ambiente adequado e acolhedor, provendo o cliente de suprimento adaptativo, em outros não.

A dinâmica destas instituições, em algumas situações, suportava seus conflitos (não-ditos aqui) e não os projetava maciçamente sobre estes clientes e, infelizmente, em outros não. Ou seja: pode-se dizer que, com profissionais bem treinados e fazendo a boa escuta, o aconselhamento psicológico pode se revelar como um instrumento que possibilita ao paciente:

a) lidar com o sofrimento psíquico que o resultado HIV positivo mobiliza;

b) ter a chance de falar de suas angústias;

c) superar as dificuldades em compartilhar a notícia com parceiros e familiares, e 
d) tirar dúvidas sobre prevenção de DST/HIV/AIDS.

Todos esses, objetivos preconizados pelos treinamentos institucionais, muitas vezes já repassados e decorados.

As histórias contadas revelaram como cada um dos entrevistados se sentiu ao receber o resultado do teste nesses CTA, e como a profissional que o atendeu interagiu com ele. Caracterizam-se as singularidades dos clientes, as suas implicações subjetivas, bem como as de suas aconselhadoras. Contudo, é bom que se tenha em conta que nunca se esgotarão as necessidades e carências dos sujeitos, bem como as formas pelas quais são constituídos os laços sociais. Pois, como FREUD (1930 [1929]) assinalou ao apontar a existência de toda uma vida psíquica inconsciente, não se pode dar conta de todo o conteúdo reprimido, nem de todo o mal-estar humano. Não se pode, em um encontro como esse, levantar todas as barreiras morais, éticas, estéticas ou de vergonha, sociais e ontológicas, nem cuidar de todas as demandas. Tampouco se poderá ignorar sua existência.

As questões apontadas nesta investigação alertam para a necessidade de se adaptar o aconselhamento sorológico às características e às histórias de cada sujeito às dos aconselhadores. O aconselhamento "padronizado" funcionou bem para uns, quando levado a cabo em toda a sua amplitude de escuta, permitindo, com isso, a ativação dos recursos dos sujeitos. Todavia, não foi favorável para outros, quando simplesmente seguiu seu script, e aboliu a inter-humanidade.

Ao se pensar no setting em sentido winnicottiano, não se elimina o trabalho institucional formalizado e constituído, necessário a suprir as carências de saúde da coletividade. No entanto, essa abordagem ora intentada alarga o horizonte do trabalho em saúde (no sentido reflexivo e humanizado) e ajuda a lembrar que os aconselhados trazem em suas narrativas as suas pessoalidades, cujos nomes, histórias e demandas próprias precisam ser ouvidos.

O ser humano luta para não morrer desde que nasce. O diagnóstico de HIV positivo atualiza essa luta. Ele prenuncia a doença crônica incurável que fará parte da vida daquele sujeito até o dia de sua morte. Assim, conhecer o status sorológico positivo presentifica e inscreve uma dimensão mais concreta a essa luta.

Neste ponto, pode-se relembrar a indagação do início do capítulo de 
apresentação dos resultados: - como pode o aconselhador saber das coisas que se passam no âmbito das vivências psíquicas de cada cliente em particular? Pode-se conjeturar que talvez ele possa. Posto que, há (ou deveria haver) uma disposição que sustenta o trabalho do aconselhador. Essa disposição está presente de modo efetivo como saber tácito, ou inscrito formalmente nas prescrições, manuais e treinamentos efetuados por ele. De que se trata essa disposição? De uma espécie de saber que indica que a vinda de toda e qualquer pessoa ao encontro do "serviço" está impregnada de inquietações, temores, apreensões, angústias e vergonhas e, principalmente, de desconforto daquele lugar onde está colocado. Em última instância, há a presença de um saber que não elimina a dimensão subjetiva do cliente, justamente por sabê-la existente. Contudo e paradoxalmente, trata-se de um saber que não se antecipa, que não se expressa ou se coloca apriorísticamente, mas se silencia na expectativa de uma manifestação da subjetividade que se sabe presente. É por isso que foi utilizado aqui o termo disposição, que se remete a artefato ou lugar disponível e ao mesmo tempo atitude ou motivação de se prestar à (estar disposto a lutar!).

Assim, trata-se de um saber que organiza e dá sentido ao encontro do aconselhador com o aconselhante. É um lugar que é constituinte do lugar próprio do aconselhador. Ou seja: um existe porque o outro existe. É a existência de um que confere a existência do outro. Repetindo o dizer de WINNICOTT (1967a): "Este é o local que me dispus a examinar (destaque do autor), a separação que não é uma separação, mas uma forma de união" (p.136).

É a possibilidade de o cliente ser ouvido e reconhecido, de ser colocado em um mundo compartilhado. É a condição para a experiência ter e fazer sentido para ele, para que possa relacionar, a seu modo, tudo e todos que o cercam e, finalmente, poder explicitar, também na sua medida e permissão, a sua própria versão da comunicação de sua soropositividade.

Com tantos envolvidos, o contexto muda continuamente e novas versões de aconselhamento são construídas. Por meio da versão de cada cliente se pode chegar a uma versão inédita do aconselhador. O sentido adquirido a partir daí para o trabalho é o da criatividade, que existe, mas muitas vezes fica obscurecida e obstaculizada 
pelo excesso de burocracia institucional impressa nas ações repetitivas dos profissionais. Assim, ambos (aconselhador e aconselhado) podem sair revigorados da situação compartilhada, pela vivência transicional do momento de revelação do diagnóstico HIV positivo.

Pois, como contou o mais novo dos entrevistados:

"É horrível, gente, receber esse resultado! A pior coisa, mesmo! Não é bom pra ninguém, acredito. Acho que nem pra pessoa que saiba de tudo nesse mundo, acho que jamais ia gostar de receber uma coisa dessas. Mas só que também não é o fim da vida não. Entendeu? Penso, assim, que tudo continua, né?”

Bruno, solteiro, 21 anos. 


\section{REFERÊNCIAS BIBLIOGRÁFICAS}

1. Abate MC. No lugar da tutela, o diálogo e o protagonismo. In: Mesquita F; Souza C R (Org.). DST/AIDS: a nova cara da luta contra a epidemia na cidade de São Paulo = ETS/SIDA: la nueva cara de la lucha contra la epidemia em la ciudad de São Paulo. São Paulo: Raíz da Terra; 2003. p. 25-37.

2. Aggleton P. Fala de Peter Aggleton. In: Os atuais desafios para a epidemia da aids — vistos da África do Sul, Austrália, Inglaterra e Canadá; 2006 maio 8; São Paulo, Brasil. Disponível em: <http://www.usp.br/nepaids/aggleton.doc $>$ [2006 jun. 20].

3. Bardin L. Análise de conteúdo. Trad. de LA Lopes e A Pinheiro. Lisboa: Edições 70; 1995.

4. Barroso MGT, Franca ISX de, Farias FSAB, Miranda KCL. Aconselhamento em HIV/AIDS como prática educativa interdisciplinar: reflexões e possibilidades. J. Bras. Aids 2003; 4(1): 23-27.

5. Bauleo A. Notas de psicologia e psiquiatria social. Trad. de M Tanis. São Paulo: Escuta; 1988.

6. Betini G. Da informação em saúde ao serviço como informação. São Paulo; 1997. [Dissertação de Mestrado - Faculdade de Saúde Pública da Universidade de São Paulo].

7. Blanchet A. L'enquête et les methodes: l'entretien. Paris: Nathan; 1992. [Trad. para uso didático de G Menezes-versão preliminar sujeita a revisão].

8. Caldeira TP do. A política dos outros. São Paulo: Brasiliense; 1984. Imagens do poder e da sociedade; p. 143-51.

9. Cavallari CD. O impacto da comunicação do diagnóstico HIV positivo: a ruptura de campo diante da soropositividade. São Paulo; 1997. [Dissertação de Mestrado - Programa de Pós-graduação em Psicologia Clínica da PUC-SP].

10. Conselho Nacional de Saúde. Resolução $\mathbf{N}^{\mathbf{o}}$ 196/96. Disponível em: $<$ http://www.conselho.saude.gov.br $>$ [2003 jun. 8]. 
11. Costa JF. Psiquiatria burocrática: duas ou três coisas que sei dela. In: Aragão LT de, Calligaris C, Costa JF, Souza O. Clínica do social: ensaios. São Paulo: Escuta; 1991.

12. Costa MA de O. Aconselhamento para o teste anti-HIV: o olhar de profissionais de unidades de saúde de Belo Horizonte. Belo Horizonte; 2004. [Dissertação de mestrado - Escola de Enfermagem da Universidade Federal de Minas Gerais].

13. Counseling, Santé et Développement. 2002. Disponível em: URL: $<$ http://www.counselingvih.org/pt/definition/champapplication.php $>$ [2005 maio 27]

14. Eksterman VF, Procaci ACM, Fairclough LFO, Mello MPF, Rocha PC. Hemofilia e aids. In: Mello J de e col. Psicossomática hoje. Porto Alegre: Artes Médicas; 1992. p. 325-33.

15. Feliciano KV de O; KOVACS MH. As necessidades comunicacionais das práticas educativas na prevenção da tranmissão materno-fetal do HIV. Rev Bras Saúde Matern Infant 2003; 3(4): 393-400.

16. Ferreira CV de L. Conversando com o paciente HIV positivo: um estudo clínico. Campinas; 1992. [Tese de Doutorado - Faculdade de Ciências Médicas da UNICAMP].

17. Ferreira M de PS, Silva CMFP da, Gomes MCF, Silva SMB da. Testagem sorológica para o HIV e a importância dos Centros de Testagem e Aconselhamento (CTA). Resultados de uma pesquisa no Município do Rio de Janeiro. Ciênc. Saúde Coletiva [periódico on line] 2001; 6(2): 481-90.

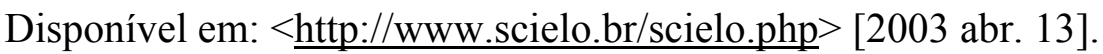

18. Filgueiras SL, Deslandes SF. Avaliação das ações de aconselhamento. Análise de uma perspectiva de prevenção centrada na pessoa. Cad. Saúde Pública [periódico on line] 1999; 15(2):121-31. Disponível em:

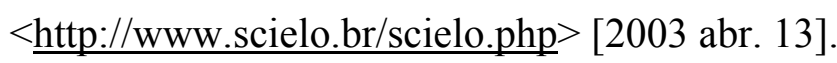

19. Fortes PAC. Ética e saúde. São Paulo: Pedagógica Universitária; 1998. Ética nas pesquisas em seres humanos; p. 105-19. 
20. Freud S. Leonardo da Vinci e uma lembrança da sua infância (1910). In: Obras psicológicas completas. Ed. Standard Brasileira. Rio de Janeiro: Imago; 1974. v. XI.

21. Freud S. O Moisés de Michelângelo (1914). In: Obras psicológicas completas. Ed. Standard Brasileira Rio de Janeiro: Imago; 1974. v. XIII.

22. Freud S. Luto e melancolia (1917 [1915]). In: Obras psicológicas completas. Ed. Standard Brasileira. Rio de Janeiro: Imago; 1974. v. XIV.

23. Freud S. O ego e o id (1923). In: Obras psicológicas completas. Ed. Standard Brasileira. Rio de Janeiro: Imago; 1974. v XIX.

24. Freud S. O mal-estar na civilização (1930 [1929]). In: Obras psicológicas completas. Ed. Standard Brasileira. Rio de Janeiro: Imago; 1974. v. XXI.

25. Galant JE. HIV counseling, testing and referral. Amer Fam Physic 2004; 70(2): 295-302.

26. Giovanetti A. Uma psicanálise sem dentro e fora. In: Barone LMC (org). O psicanalista: hoje e amanhã. São Paulo: Casa do Psicólogo; 2002. p.37-45. [Apresentado no $2^{\circ}$ Encontro Psicanalítico da Teoria dos Campos. São Paulo: 2001].

27. Giron KC, Mondini LG, Ikeda MLR, Lenz MC. Uma estratégia de atenção em HIV/AIDS: centro de testagem e aconselhamento. Porto Alegre; 2002. [Monografia - Escola Nacional de Saúde Pública Sérgio Arouca].

28. Herrmann F. Andaimes do real. $2^{a}$ ed. São Paulo: Brasiliense; 1991.

29. Hsiao CF, Chao SL, Tsai TC, Chuang P. Effects of stepped counselling intervention on quality of life among newly diagnosed HIV-positive patients. Hu Li Za Zhi 2004; 51(2): 39-47.

30. Isezuo AS, Onayemi O. Attitudes of patients towards voluntary human immunodeficiency vírus counselling and testing in two Nigerian tertiary hospitals. West Afr J Med 2004; 23(2): 107-10.

31. Kaës R. O grupo e o sujeito do grupo: elementos para uma teoria psicanalítica do grupo. Trad. de J de S e M Werneck. São Paulo: Casa do 
Psicólogo; 1997. O inconsciente e o grupo; p. 91-118.

32. Kaës $\mathrm{R}$ et al. A instituição e as instituições: estudos psicanalíticos. Trad. de J. Pereira Neto. São Paulo: Casa do Psicólogo; 1989.

33. Khan MMR. (1968) Introdução. In: Winnicott DW. Holding e interpretação. Trad. de SMTM de Barros. 2a ed São Paulo: Martins Fontes; 2001. p. 1-25.

34. Kilmarx PH, Hamers FF, Peterman TA. Living with HIV. Experiences and perspectives of HIV-infected sexually transmitted disease clinic patients after posttest counseling. Sex Transm Dis 1998; 25(1): 28-37.

35. Klouri C. Drogadição e aids: vivendo entre duas mortes. São Paulo; 1992. [Dissertação de Mestrado - Programa de Pós-graduação em Psicologia Clínica da PUC-SP].

36. Landroni MAS. Aids e gravidez: desafios para o cuidado nos serviços de saúde. São Paulo; 2004. [Dissertação de Mestrado - Faculdade de Saúde Pública da Universidade de São Paulo].

37. Laplanche J, Pontalis JB. Vocabulário de psicanálise. $5^{\mathrm{a}}$ ed. Lisboa: Moraes Editores; 1970.

38. Lemos MTG de. Quarta fala. In: Jornada Psicanálise e Aids; 1997 jun 28; Campinas, São Paulo. Campinas: Escola Lacaniana de psicanálise de Campinas; 1998, p.19-22.

39. Lindgren S, Ottenblad C, Bengtsson AB, Bohlin AB. Pregnancy in HIV-infected women. Counseling and care-12 years' experiences and results. Acta Obstet Gynecol Scand 1998; 77(5): 532-41.

40. Loparic Z. Esboço do paradigma winnicottiano. In: Madaleine Davis Memorial Lecture. 2000 Jul 1; Londres (UK): Squiggle Foundation. Versão ampliada [mimeo].

41. Lopes F. Mulheres negras e não negras vivendo com HIV/AIDS no estado de São Paulo: um estudo sobre suas vulnerabilidades. São Paulo; 2003. [Dissertação de mestrado - Faculdade de Saúde Pública da Universidade de São Paulo]. 
42. Mesquita F, Souza CR de (org). DST/Aids: a nova cara na luta contra a epidemia na cidade de São Paulo. ETS/SIDA: la nueva cara de la lucha contra la epidemia em la ciudad de São Paulo. São Paulo: Raiz da Terra; 2003.

43. Meursing K; Sibindi F. HIV counseling-a luxury or necessity? Health Policy Plan 2000. 15(1): 17-23.

44. Minayo MC de $\mathrm{S}$. O desafio do conhecimento. Pesquisa qualitativa em saúde. $3^{\text {a }}$ ed. São Paulo-Rio de Janeiro: HUCITEC-ABRASCO; 1994.

45. Ministério da Saúde. Coordenação Nacional de DST e Aids. Diretrizes dos Centros de Testagem e Aconselhamento (CTA): manual. Brasília (DF); 1999a.

46. Ministério da Saúde. Coordenação Nacional de DST e Aids. Aconselhamento em DST, HIV e aids: diretrizes e procedimentos básicos. Brasília (DF); 1999b.

47. Ministério da Saúde. Coordenação Nacional de DST e Aids. Capacitação nacional para implantação do Sistema de Informação dos Centros de Testagem e Aconselhamento em Aids (SI-CTA): manual de utilização. Brasília (DF); 2002.

48. Ministério da Saúde. Coordenação Nacional de DST e Aids. Disponível em: < http://www.aids.gov.br/prevenção/políticasdeprevenção/html > [2003 maio 19].

49. Ministério da Saúde. Programa Nacional de DST e Aids. Disponível em: $<$ http://www.aids.gov.br/final/diagnostico/aids/direta.htm $>$ [2005 ago. 11]

50. Ministério da Saúde. Projeto Humaniza SUS. Disponível em:

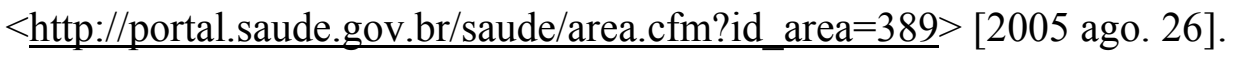

51. Moherdaui F. Abordagem sindrômica das doenças sexualmente transmissíveis. J Bras Doen Sex Transm 2000; 12(4): 40-9.

52. Molassiotis A, Lallaghan P, Twinn SF, Chung WY, Li CK. A pilot study of the effects of cognitive-behavioral group therapy and peer support/counseling en decreasing psychological distress and improving quality of life in Chinese 
patients with syntomatic HIV disease. AIDS Patient Care STDS 2002; 16(2): 83-96.

53. Moreno DMFC. A saúde pública e a psicanálise: a produção do conhecimento no Brasil acerca da aids. São Paulo; 2001. [Dissertação de Mestrado Faculdade de Saúde Pública da Universidade de São Paulo].

54. Moreno DMFC, REIS AOA. O momento da comunicação do resultado sorológico para o HIV sob a ótica winnicottiana. Pulsional Rev de Psicanálise 2002; 156: 20-5.

55. Oliveira SMS. Sobre o morrer: a vida psíquica e suas implicações na exposição ao HIV. São Paulo; 2003. [Dissertação de Mestrado - PPG/CIP SES].

56. OMS - Organisation Mondiale de la Santé. Guide pour le conseil dans l'infection à VIH et le SIDA. (Série OMS SIDA, 8). Genève; 1991. Disponível em: $<$ http://whqlibdoc.who.int/aids/WHO_AIDS_8 fre.pdf $>$ [2006 maio 27].

57. ONUSIDA - Programme Commun des Nations Unis sur le VIH/SIDA. L'impact du conseil et du test volontaires: aperçu à l'échelle mondiale des avantages et des difficultés. Genève: ONUSIDA; 2002. Disponível em:

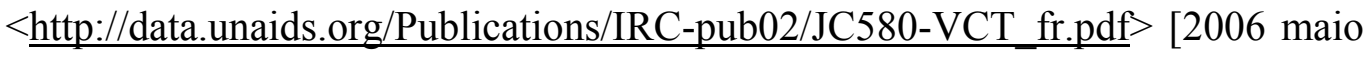
27].

58. Paiva V. O sujeito sexual: uma proposta de intervenção. Sexualidade Gênero Sociedade. 1998; 1(10): 4-8.

59. Paiva V. Sem mágicas soluções: a prevenção e o cuidado em HIV/AIDS e o processo de emancipação psicossocial. Interface-Comunic, Saúde, Educ 2002; 6(11): 25-38.

60. Paiva V, Latorre M do R, Gravato N, Lacerda R. Sexualidade de mulheres vivendo com HIV/AIDS em São Paulo. Cad. Saúde Pública [periódico on line] 2002;

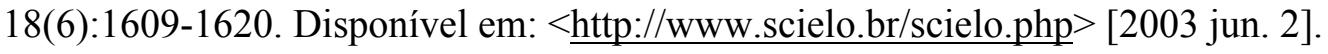

61. Patterson LE, Eisenberg S. O processo de aconselhamento. Trad. de M Alonso. $3^{\text {a }}$ ed. São Paulo: Martins Fontes; 2003. Algumas perspectivas sobre ajuda efetiva; p. 1-18. 
62. Patterson LE, Eisenberg S. O processo de aconselhamento. Trad. de M Alonso. $3^{\mathrm{a}}$ ed. São Paulo: Martins Fontes; 2003. O aconselhamento como processo; p. 1938.

63. Pechansky FP, Inciardi JA, Kohlrausch E. Uma proposta para treinamento em intervenções preventivas sobre HIV/AIDS em usuários de drogas de Porto Alegre. Rev Psiquiatr Rio Grd do Sul 1996; 18(3): 375-81.

64. Pereira MG. Epidemiologia: teoria e prática. $8^{\mathrm{a}}$ ed. Rio de Janeiro: Guanabara Koogan; 2005. Métodos empregados em epidemiologia; p. 269-288.

65. Pessoa Labaki ME. Aids: uma clínica da indagação. Cad. de Subjetividade 1996; 4(1/2): 153-61.

66. Petchesky RP. Direitos sexuais: um novo conceito na prática política internacional. In: Barbosa R; Parker R (org.). Sexualidades pelo avesso: direitos, identidades e poder. Rio de Janeiro: Editora 34, 1999. p. 15-38.

67. Prado BMC. O aconselhamento em DST para adolescentes: um caminho a percorrer. São Paulo; 2004. [Dissertação de Mestrado - Faculdade de Saúde Pública da Universidade de São Paulo].

68. Queiroz MIP. Variações sobre a técnica do gravador no registro da informação viva. São Paulo: T.A. Queiroz; 1991.

69. Reilly T, Woo G. Access to services and maintenance of safe sex practices among people living with HIV/AIDS. Soc Work Health Care 2003; 36(3): 8195.

70. Rogers C. Psicoterapia e consulta psicológica. Lisboa: Moraes Editores; 1974a. O lugar da consulta psicológica; p. 15-29.

71. Rogers C. Psicoterapia e consulta psicológica. Lisboa: Moraes Editores; 1974b. Antigas e novas perspectivas sobre a consulta psicológica e a psicoterapia; p. 3058.

72. Rogers C. Terapia centrada no cliente. Trad. de M do C Ferreira. Lisboa: Moraes Editores; s.d. Perspectivas actuais da terapia centrada no paciente; p. 1732. 
73. Rogers C. Terapia centrada no cliente. Trad. de M do C Ferreira. Lisboa: Moraes Editores; s.d. A actividade e a orientação do conselheiro; p. 33-76.

74. Rohleder P, Swartz L. 'What I've noticed what they need is the stats': lay HIV counsellors' reports of working in a task-orientated health care system. AIDS Care 2005; 17(3): 397-406.

75. Roudinesco E, Plon M. Dicionário de psicanálise. Trad. de VRL Magalhães. Rio de Janeiro: Jorge Zahar; 1998.

76. Rudy ET, Mahoney-Anderson PJ, Loughlin AM, Metsch LR, Kerndt PR, Gaul Z, Del Rio C, ARTAS Group. Perceptions of human immunodeficiency vírus (HIV) testing services among HIV-positive persons not in medical care. Sex Transm Dis 2005; 32(4); 207-13.

77. Sanches RM. Escolhi a vida: desafios da aids mental. São Paulo: Olho d'Água; 1997.

78. Santos CP, Nascimento VLV do, Felipe YX. Aderência ao tratameto antiretroviral: resultados preliminares e reflexões da experiência em um serviço universitário - Casa da Aids. In: Teixeira PR, Paiva V, Shimma E, organizadores. Tá difícil de engolir? Experiências de adesão ao tratamento anti-retroviral em São Paulo. São Paulo: NEPAIDS; 2000. p. 115-27.

79. Scheeffer R. Aconselhamento psicológico. $6^{\mathrm{a}}$ ed. São Paulo: Atlas; 1976a. O aconselhamento não-diretivo. Conceitos básicos; p. 58-68.

80. Scheeffer R. Teorias de aconselhamento. São Paulo: Atlas; 1976b. Aconselhamento e psicoterapia; p. 16-23.

81. Secretaria Municipal da Saúde de São Paulo. Projeto Acolhimento. Disponível em: $\quad<$ http://portal.prefeitura.sp.gov.br/secretarias/saude/projetos_prioritarios/ $\underline{0007}>$ [2005 ago. 26].

82. Sliep Y, Poggenpoel M, Gmeiner A. A care counselling model for HIV reactive patients in rural Malawi - Part II. Curiationis 2001; 24(3): 66-74.

83. Spielberg F, Kurth A, Gorbach PM, Goldbaum G. Moving from apprehension to action: HIV counseling and testing preferences in three at-risk populations. AIDS 
Educ Prev 2001; 13(6): 524-40.

84. St Lawrence JS, Eldridge GD, Brasfield TL. Behavior and psychosocial consequences of HIV antibody counseling and testing with african american women. Womens Health 1998; 4(2): 135-53.

85. Stefflre B e Grant WH. Teorias de aconselhamento. Trad. de EMB da Rocha; N Sáfady e WMA Penteado. São Paulo: Mc Grau-Hill do Brasil; 1976.

86. Sweat M, Gregorich S, Sangiwa G, Furlonge C, Balmer D, Kamenga C, Grinstead O, Coates T. Cost-effectiveness of voluntary HIV-1 counselling and testing in reducing sexual transmission of HIV-1 in Kenya and Tanzania. Lancet 2000; 356: 113-21.

87. The voluntary HIV-1 counseling and testing efficacy study group. Efficacy of voluntary HIV-1 counselling and testing in individuals and couples in Kenya, Tanzania, and Trinidad: a randomised trial. Lancet 2000; 356: 103-12.

88. Turato ER. Tratado da metodologia da pesquisa clínico-qualitativa: construção teórico-epistemológica, discussão comparada e aplicação nas áreas da saúde e humanas. Petrópolis, RJ: Vozes, 2003. $2^{\mathrm{a}}$ ed. Construindo uma nova e particular metodologia qualitativa a partir do casamento de métodos modelares; p. 225-44.

89. Turato ER. Tratado da metodologia da pesquisa clínico-qualitativa: construção teórico-epistemológica, discussão comparada e aplicação nas áreas da saúde e humanas. $2^{\mathrm{a}}$ ed. Petrópolis, RJ: Vozes, 2003. Clarificando para o empreendimento da pesquisa clínico-qualitativa; p. 245-304.

90. Turato ER. Tratado da metodologia da pesquisa clínico-qualitativa: construção teórico-epistemológica, discussão comparada e aplicação nas áreas da saúde e humanas. $2^{\mathrm{a}}$ ed. Petrópolis, RJ: Vozes, 2003. Tratando e discutindo os dados para a contribuição do pesquisador ao repensar do conhecimento cientifico; p. 437-522.

91. Vaisberg TM. Marionetes em consultas terapêuticas: a teoria dos campos na fundamentação de enquadres transicionais. In: Barone LMC (org). O psicanalista: hoje e amanhã. São Paulo: Casa do Psicólogo; 2002. p. 203-22. 
[Apresentado no $2^{\circ}$ Encontro Psicanalítico da Teoria dos Campos. São Paulo: 2001.]

92. Vollmer NA, Valadez JJ. A psychological epidemiology of people seeking HIV/AIDS counselling in Kenia: an approach for a improving counsellor training. AIDS 1999; 20; 13(12): 1557-67.

93. WHO-World Health Organization. Regional Office for Europe. Counselling and care services for HIV-positive individuals, AIDS patients and their contacts: report on a WHO working group. Copenhagen; 1989. (EUR/HFA target 4). Disponível em: < http://whqlibdoc.who.int/euro/-1993/EUR_ICP_GPA_015.pdf $>$ [2006 maio 27].

94. Winnicott DW (1951). Textos selecionados: da pediatria à psicanálise. Trad. de J Russo. Rio de Janeiro: Francisco Alves; 1978. Objetos transicionais e fenômenos transicionais; p. 389-408.

95. Winnicott DW (1954-5). Textos selecionados: da pediatria à psicanálise. Trad. de J Russo. Rio de Janeiro: Francisco Alves; 1978. Aspectos clínicos e metapsicológicos da regressão no setting psicanalítico; p.459-82.

96. Winnicott DW (1955-6). Textos selecionados: da pediatria à psicanálise. Trad. de J Russo. Rio de Janeiro: Francisco Alves; 1978. Variedades clínicas da transferência; p. 483-9.

97. Winnicott DW (1967a). O brincar e a realidade. Trad. de JO de A Abreu e V Nobre. Rio de Janeiro: Imago; 1975. A localização da experiência cultural; p.133-43.

98. Winnicott DW (1967b). Tudo começa em casa. $3^{\text {a }}$ ed. Trad. de P Sandler. São Paulo: Martins Fontes; 1999. O conceito de indivíduo saudável; p. 3-22.

99. Winnicott DW (1968). O jogo do rabisco [Squiggle game]. In: Winnicott C; Shepherd R; Davis M. Org. Explorações psicanalíticas. Trad. de J O de A Abreu. Porto Alegre: Artes Médicas; 1994. p.230-43.

100. Winnicott DW. O brincar e a realidade. Trad. JO de A Abreu e V Nobre. Rio de Janeiro: Imago; 1975. 
101. Winnicott DW. Consultas terapêuticas em psiquiatria infantil. Trad. de JMX Cunha. Rio de Janeiro: Imago; 1984. Introdução; p. 9-19.

102. Winnicott DW. Holding e interpretação. Trad. de SMTM de Barros. $2^{\mathrm{a}}$ ed. São Paulo: Martins Fontes; 2001.

103. Yazlle MEHD, Duarte G, GIR E. Sexo seguro na adolescência. Reprod Clim 1999; 14(1): 16-8. 
ANEXOS 


\section{ANEXO 1 \\ UNIDADES DE DST/AIDS SEGUNDO MACRO REGIÕES MUNICÍPIO DE SÃO PAULO}

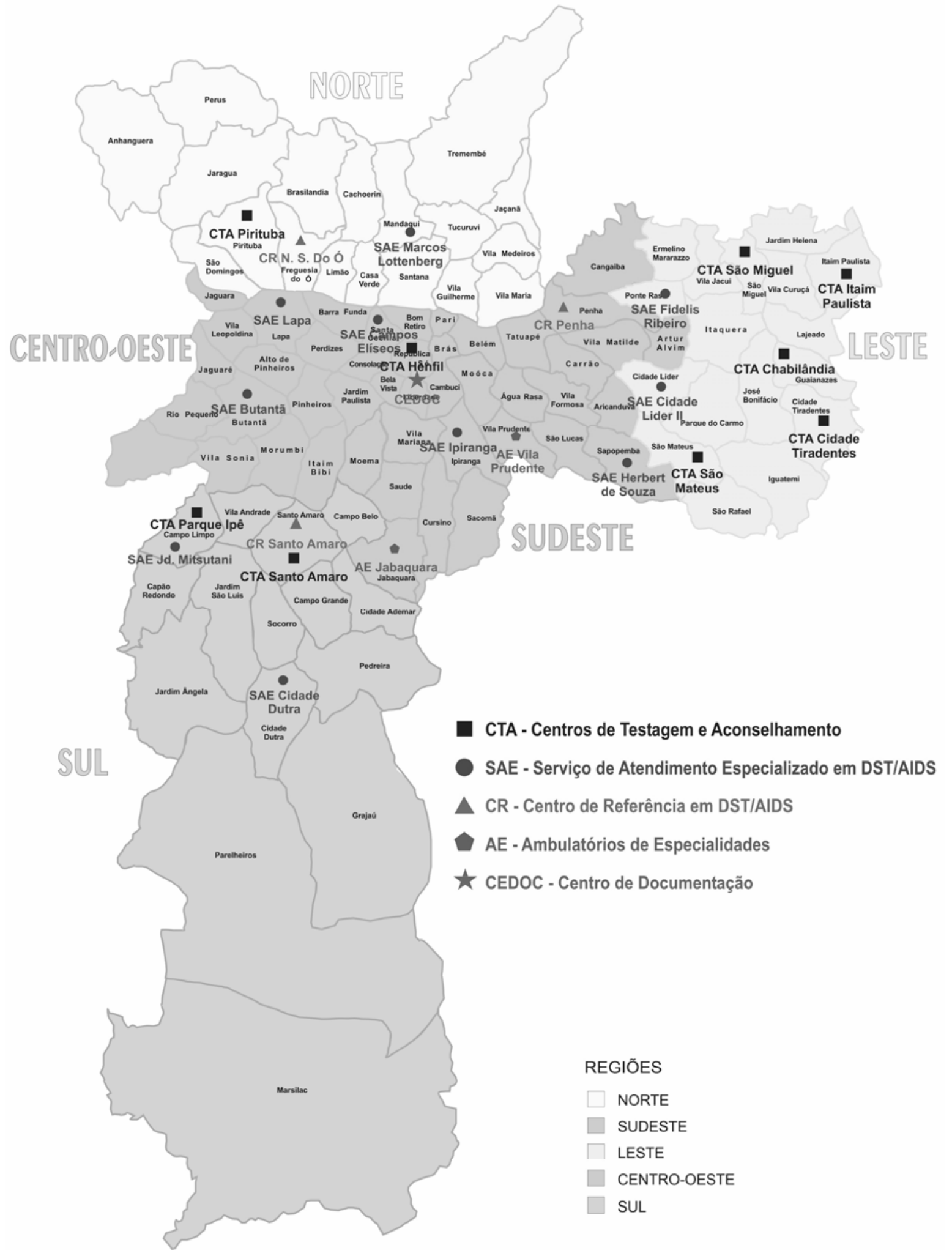




\section{ANEXO 2 - TERMO DE CONSENTIMENTO LIVRE E ESCLARECIDO}

\section{Projeto de Pesquisa:}

Pesquisadora: Diva Maria Faleiros Camargo Moreno

Profissão: Psicóloga

Departamento de Saúde Materno-Infantil da Faculdade de Saúde Pública da Universidade de São Paulo - Fone: 30667703

Você está sendo convidado para participar de um projeto de pesquisa para estudar se o aconselhamento sorológico realizado nos Centros de Testagem e Aconselhamento em DST e Aids do Município de São Paulo possibilita aos clientes serem ouvidos em suas preocupações e sentimentos decorrentes da comunicação do resultado positivo para o HIV, e se fornece as informações necessárias para avaliar sua situação de risco particular e para adotar práticas preventivas em relação às DST e aids.

Para isso, você participará de uma entrevista para falar um pouco de como foi esse momento para você.

A entrevista é sigilosa, nem você, nem as pessoas envolvidas no estudo serão identificadas, embora a entrevista seja gravada para não perder as informações. Se restar alguma dúvida para a pesquisadora sobre o que conversaram, ela poderá marcar um novo contato com você, se você concordar.

Essas entrevistas serão utilizadas para realização de uma tese de doutorado que será apresentada na Faculdade de Saúde Pública da USP.

A não aceitação ou desistência, durante o processo da entrevista, não implicará em nenhum prejuízo para você como usuário dessa Unidade de Saúde.

Declaro, que após ter sido esclarecido sobre a pesquisa, consinto em participar na qualidade de voluntário desse projeto de pesquisa.

São Paulo, de de .

Nome:

Fone de contato: horário para contato

Voluntário Profissional 


\section{ANEXO 3 - FORMULÁRIO DE ATENDIMENTO DOS CTA} FORMULÁRIO DE ATENDIMENTO DO SI-CTA

\section{LOCAL DE ORIGEM:}

DATA ATENDIMENTO:

\section{$\begin{array}{lll}l & 1 & \text { TIPO de ORIENTAÇÃo (PRÉ-Teste): }\end{array}$}

NNo DE REQUISIÇÃo NO SI-CTA:

VAI FAZER COLETA

[ ] Individual [ ] Nenhuma

ORIENTADOR(ES):

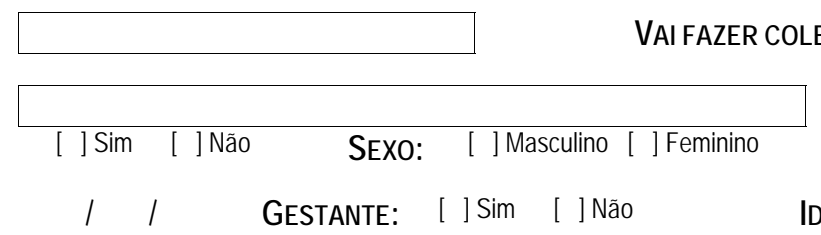

[ ] Coletiva [ ] Individual e Coletiva

NOME (SENHA):

TESTE NOMINAL:

DATA DE

NASCIMENTO:

ZONA:

[ ] Urbana [ ] Rural CIDADE:

DE PROTOCOLO:

BAIRRO:

Motivo da Procura: [1] Exposição a situação de risco

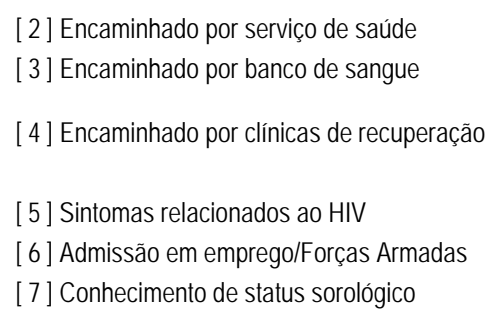

[2] Encaminhado por serviço de saúde

[4] Encaminhado por clínicas de recuperação

[5] Sintomas relacionados ao HIV

[6] Admissão em emprego/Forças Armadas

[7] Conhecimento de status sorológico
[8] Exame pré-natal
[9] Conferir resultado anterior (da $1^{\mathrm{a}}$ amostra)
[10] Janela imunológica
[11] DST
[12] Prevenção
[13] Outros. Especificar:

Mostra Nome Etiqueta: [ ] ] Sim [ ]

IDADE GESTACIONAL (MESES): Não<smiles>[C-]1=CC=C1</smiles>

ESTADO/UF:

\begin{tabular}{|rl|}
\hline PRIMEIRO TESTE NESTE & [ ] Sim [ ] Não \\
CTA: & \\
1 a AMOSTRA: & [ ] Sim [ ] Não \\
MotIVO DA REPETIÇÃO: & [3 ] Conferir resultado \\
anterior \\
No DE REQUISIÇÃo \\
[NTERIOR: ] \\
(na 1a amostra)
\end{tabular}

\section{Encaminhamentos Pré-Teste (Marque com X a} opção):
[1] Nenhum
[2] Repetir/Inconclusivo
[3] Repetir/Janela imunológica
[ 4 ] Repetir/2a amostra
[5] Ambulatório
LOCAL DE

[6] Psicólogo

[7] Tratamento de DST

[8] Realizar HIV

[9] Orientações Gerais

ENCAMINHAMENTO:

[10] Outros.
ESCOLARIDADE (em anos de estudos concluídos):
[1] Nenhum
[2] 1 a 3 anos de estudos concluídos
[3] 4 a 7 anos de estudos concluídos
[4 ] 8 a 11 anos de estudos concluídos
[5] 12 a mais anos de estudos concluídos
[99] Não informado

SITUAÇÃo PROFISSIONA
[1] Autônomo
[2 ] Desempregado
[3] Empregado
[4] Apenas estudante
[5] Do lar
[6] Aposentado
[99] Não informado

JÁ PROCUROU BANCO DE SANGUE PARA FAZER TESTE PARA HIV: [ ] Sim [ ] Não

\section{ORIGEM DA CLIENTELA:}

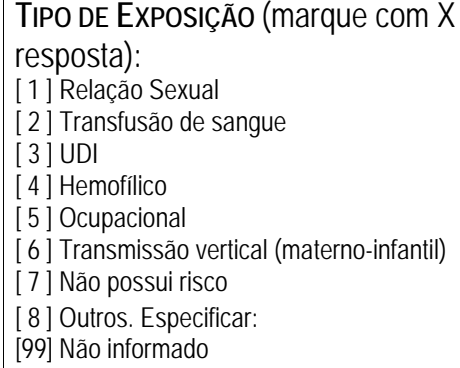

\section{COMPARTILHOU SERINGAS COM} OUTROS USUÁRIOS NO ÚLTIMO ANO?
[1] Sim [2] Não [3] Não lembra
[98] Não se aplica [99] Não informado

Pegou algum tipo de DST no № DE PARCEIROS SEXUAIS NO ÚLTIMO ANO:

\begin{tabular}{|c|c|c|c|}
\hline \multicolumn{2}{|c|}{ ÚLTIMO ANO? } & [1] Nenhum & [5] 11 a 50 \\
\hline & [ ] Não & [2] 01 & [6 ] 51 a 100 \\
\hline Especifique: & & [ 3 ] 02 a 04 & $\begin{array}{l}\text { [7] Mais de } \\
100\end{array}$ \\
\hline & & {$[4]$ os a 10} & informado \\
\hline
\end{tabular}

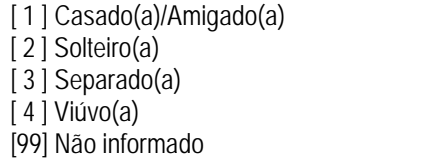

[1] Material de divulgação

[3] Jornais/Rádio/Televisão

[4] Banco de sangue

[6] Serviços de informação telefônica

[ 7 ] Outros. Especificar:

\section{NAL:}

Estado CIVIL/SituAÇÃo MARITAL: 
TIPO DE PARCEIRO (na vida):

[1] Homens

[2] Mulheres

[3] Homens e Mulheres

[98] Não se aplica

[99] Não informado

\section{MOTIVO DE NÃO USAR PRESERVATIVO COM PARCEIRO FIXO (atual):}

[1] Não gostar

[2] Não acredita na eficácia

[3] Não sabe usar

[4] Parceiro(a) não aceita

[5] Não dispunha no momento

[ 7 ] Uso de drogas/álcool

[ 8 ] Não consegue negociar

[9] Achou que o outro não tinha HIV

[10] Acha que não vai pegar

[11] Negociou não usar preservativo

\section{Uso do preservativo com}

PARCEIRO NÃO FIXO (na vida):

[1] Sempre

[2] Nunca

[3] Às vezes

[98 ] Não se aplica

[99] Não informado

\section{RECORTE POPULACIONAL:}

[1] População em geral

[2] Populações confinadas

[3] Caminhoneiros

[4] Trabalhadores do sexo

[5] Homens que fazem sexo com homens

[ 6 ] Usuários de drogas injetáveis (UDI)
[6] Confia no parceiro

USO DO PRESERVATIVO COM PARCEIRO FIXO (atual):
[1] Sempre
[2] Nunca
[3 Âs vezes
[98] Não se aplica
[99] Não informado

USO DO PRESERVATIVO NA ÚLTIMA RELAÇÃO COM PARCEIRO FIXO:

[1] $\mathrm{Sim}$

[2] Não

[ 3 ] Não lembra

[98] Não se aplica

[99] Não informado

\begin{tabular}{|ll|}
\hline \multicolumn{2}{|l|}{ RISCO DO PARCEIRO FIXO (atual): } \\
[ 1 ] Relação extra-conjugal & [8 ] Passado \\
& sexual \\
[ 2 ] Homo/bissexualidade & [9] Não atribui \\
& risco \\
[ 3 ] Transfundido & {$[10]$ DST } \\
[ 4 ] UDI & {$[11]$ Não sabe } \\
[ 5 Uso de outras drogas & {$[12]$ Outros } \\
[ 6 ] Portador de HIV & [98] Não se \\
& aplica \\
[ 7 ] Desconfia de relação & [99] Não \\
& informado \\
& \\
extra-conjugal &
\end{tabular}

[19] Outros

[98] Não se aplica

[99] Não informado

MOTIVO DE NÃO USAR PRESERVATIVO COM PARCEIRO NÃO FIXO:

[1] Não gostar [12] Não tinha consciência [13] Não tem condições

\begin{tabular}{|l|}
\hline Uso do preservativo na última \\
RELAÇÃo COM PARCEIRO NÃO \\
FIXO: \\
[1] Sim \\
[2] Não \\
[3] Não lembra \\
[98] Não se aplica \\
[99] Não informado
\end{tabular}

[ 2 ] Não acredita na eficácia

[ 3 ] Não sabe usar de comprar [14] Não deu tempo/tesão

[4] Parceiro(a) não aceita

[5] Não dispunha no momento

[6] Confia no parceiro

[ 7 ] Uso de drogas/álcool

[8] Não consegue negociar

[9] Achou que o outro não tinha HIV

[10] Acha que não vai pegar

[15] Desejo de ter filho

[16] Tamanho do preservativo pq/gd [17] Disfunção sexual

[18] Estupro/violência

[19] Outros

[98] Não se aplica [99] Não informado
[11] Negociou não usar preservativo

Encaminhamentos Pós-Teste

(marque com $X$ até 2 opções):

[1] Nenhum

[9] Portadores de DST

[10] Hemofílicos e politransfundidos

[11] Profissionais de saúde

[2] Repetir/Inconclusivo

[ 3 ] Repetir/Janela imunológica

[5] Ambulatório

[6] Psicólogo

[7] Tratamento de

DST
LOCAL DE ENCAMINHAMENTO:

Preservativos entregues:

DATA DA ENTREGA DO RESULTADO:

ORIENTADOR DA ENTREGA:

NOTAS DE ORIENTAÇÃO:
[ 4 ] Repetir/2a amostra

[8] Outros.

[12] Travestis

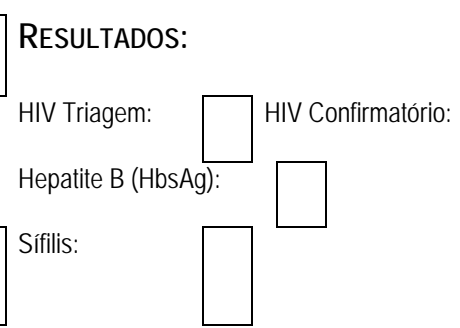

Titulação para Sífilis (Marque X):

\begin{tabular}{|l|l|}
\hline & Legenda \\
& \\
1 & - Não \\
Reagente \\
$2-$ \\
Reagente \\
$3-$ \\
Indetermin \\
ado \\
$4-$ \\
Ignorado \\
$5-$ \\
Discordant \\
e \\
$6-$ Não \\
realizado \\
\hline
\end{tabular}


ANEXO 4.- CARTAZ

\section{Seja Voluntário !!! Pesquisa}

Sobre como foi dado o resultado do seu teste HIV POSITIVO no CTA

Caso queira, você pode contribuir para a realização dessa pesquisa dando uma entrevista sigilosa. Nessa entrevista, você poderá contar como foi ouvido em suas preocupações e sentimentos a respeito desse resultado.

Por favor ligue para (nome da pesquisadora) sem qualquer compromisso, que você receberá todos os esclarecimentos.

Fone: (Números dos telefones) 
ANEXO 5 - CARTÃO-CONVITE

Seja Voluntário !!!

Pesquisa sobre como foi dado o resultado do seu teste HIV POSITIVO no CTA

Caso queira, você pode contribuir para a realização dessa pesquisa dando uma entrevista sigilosa. Nessa entrevista, você poderá contar como você foi ouvido em suas preocupações e sentimentos a respeito desse resultado.

Por favor ligue para (nome da pesquisadora) sem qualquer compromisso, que você receberá todos os esclarecimentos.

Fone: (números dos telefones) 


\section{ANEXO 6 - TÓPICOS ABORDADOS NAS ENTREVISTAS}

Após a frase introdutória, o entrevistado era indagado sobre:

- O tema central do aconselhamento.

- Como se sentiu no momento do aconselhamento.

- A possibilidade de tratar dos assuntos de seu interesse no seu aconselhamento.

- Os temas abordados pela aconselhadora. Dentre os eventuais temas, abordagem sobre aspectos ligados à prevenção, ao tratamento e ao cuidado à saúde.

- A oportunidade de falar sobre como contar o diagnóstico para outrem.

- A possibilidade de tirar dúvidas, falar de preocupações e sentimentos relativos ao resultado do teste.

- A história dos testes que já realizou. a) Caso seja o primeiro teste realizado, sobre quando recebeu o resultado. Sobre os aspectos ligados ao exame confirmatório. b) Caso não seja o primeiro, sobre aspectos ligados aos testes que realizou.

- Sentimentos que teve desde que recebeu o resultado.

- O oferecimento de outros encontros de aconselhamento além daquele que teve, caso precisasse.

- Encaminhamentos realizados para outros serviços.

- A forma como foi realizado o primeiro e o segundo aconselhamento.

- Informações a acrescentar sobre a comunicação do resultado positivo.

- Sugestões que poderiam aprimorar o aconselhamento do teste anti-HIV positivo no CTA. 